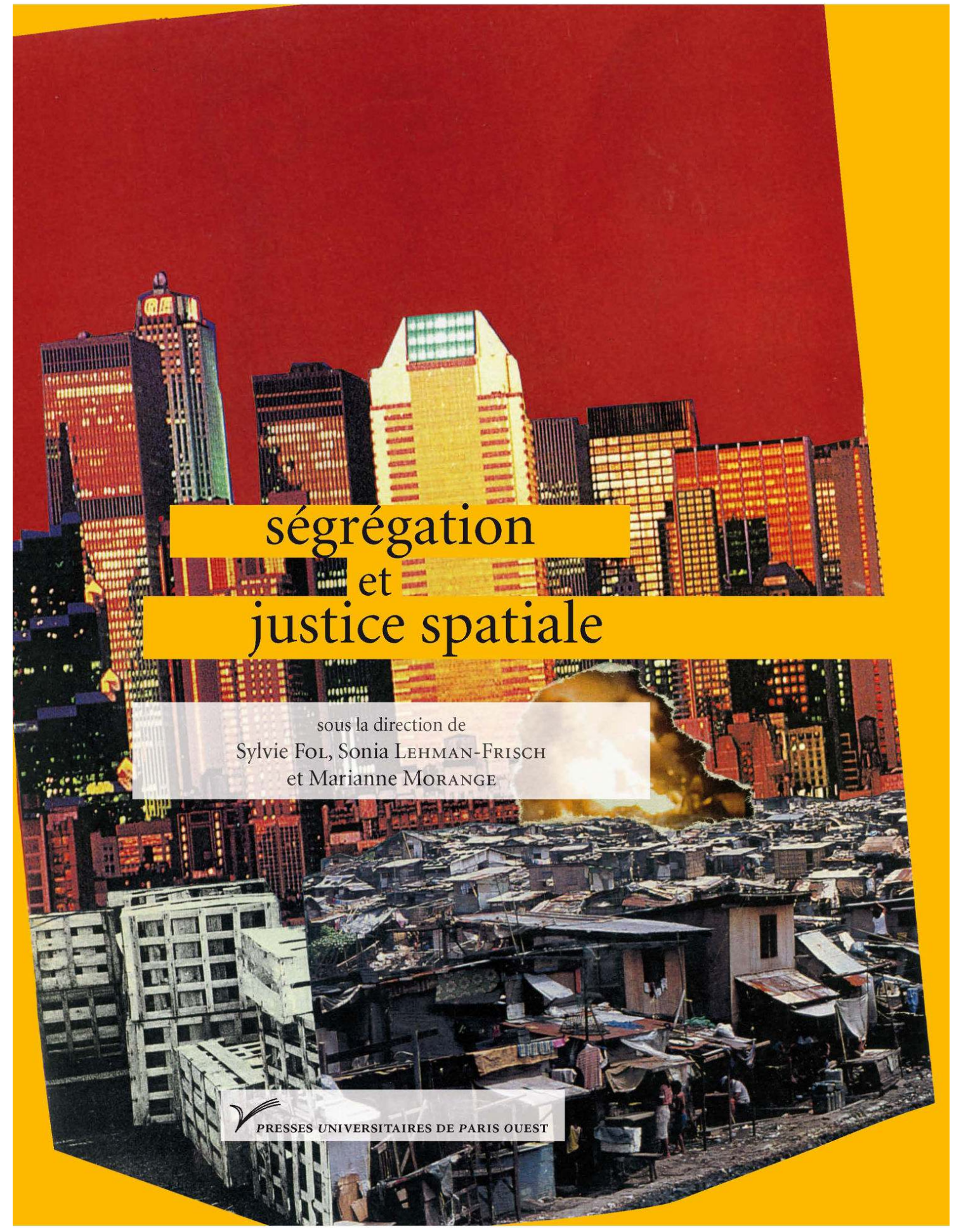




\section{Ségrégation et justice spatiale}

\section{Sylvie Fol, Sonia Lehman-Frisch et Marianne Morange (dir.)}

Éditeur : Presses universitaires de Paris

Ouest

Année d'édition : 2013

Date de mise en ligne : 20 novembre 2014

Collection : Sciences humaines et sociales

ISBN électronique : 9782821850866

\section{Sbooks}

http://books.openedition.org

\section{Édition imprimée}

ISBN : 9782840161639

Nombre de pages : 353

Ce document vous est offert par SCD Université de Paris Ouest Nanterre la

Défense

université

Paris Ouest

Nanterre bófense

Nanterre La Défense

Référence électronique

FOL, Sylvie (dir.) ; LEHMAN-FRISCH, Sonia (dir.) ; et MORANGE, Marianne (dir.). Ségrégation et justice spatiale. Nouvelle édition [en ligne]. Nanterre : Presses universitaires de Paris Ouest, 2013 (généré le 12 juillet 2016). Disponible sur Internet : <http://books.openedition.org/pupo/2111>. ISBN : 9782821850866

Ce document est un fac-similé de l'édition imprimée.

(c) Presses universitaires de Paris Ouest, 2013

Conditions d'utilisation :

http://www.openedition.org/6540 


Ségrégation et justice spatiale 



\section{Ségrégation et justice spatiale}

sous la direction de

Sylvie Fol, Sonia Lehman-Frisch

et Marianne Morange

PRESSES UNIVERSITAIRES DE PARIS OUEST 
Collection Espace et justice

dirigée par Frédéric Dufaux et Philippe Gervais-Lambony

Déja parus

Justice et injustices spatiales

B. Bret, Ph. Gervais-Lambony, Cl. Hancock, F. Landy (dir.)

Justice et injustices enironnementales

D. Blanchon, J. Gardin, S. Moreau (dir.)

Ségrégation et injustice spatiale

S. Fol, S. Lehman-Frisch, M. Morange (dir.)

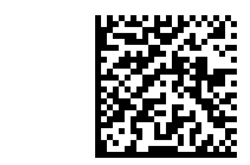

www.pressesparisouest.fr

2013

(C) Presses universitaires de Paris Ouest

ISBN : 978-2-84016-164-6

Collage de couverture : (C) Michel Coquery 


\title{
Sommaire
}

Ségrégation et justice spatiale: perspectives 9

Sylvie Fol, Sonia Lehman-Frisch et Marianne Morange

\section{GENTRIFICATION, RÉGÉNÉRATION URBAINE \\ ET URBANISME NÉOLIBERAL MONDIALISÉ}

Inner-City (Housing) Regeneration in Britain:

Tackling Spatial Injustice or the New Urban Enclosures?

Stuart HoDKINSON

Dublin's Neoliberal Agenda and the Social Cost

of Entrepreneurial Planning/

Projet néo-libéral et coût social

de l'urbanisme entrepreneurial à Dublin

Andrew MacLaran, Sinéad Kelly et Paula Brudell

Urban Vitality in San Francisco

Miriam CHION

\author{
ESPACES PUBLICS \\ ET EXCLUSION SPATIALE
}

Public Space and the Politics of Propinquity in Johannesburg/

Espace public et politique de proximité à Johannesburg.

Teresa Dirsuweit

Cultural Appeal as an Argument for Socio-spatial Segregation

María CARMAN

Ecological Gentrification: Re-negotiating Justice in the City

Sarah Dooling

"Bad Spaces?": Interrogating Suburbs,

Myth and Spatial Justice

Gary W. McDonogh 


\section{SÉGRÉGATION \\ ET RECONNAISSANCE POLITIQUE}

Californie: de la ségrégation résidentielle

à l'injustice politique.

Frédérick DouzeT

Recognizing Justice:

Identities and Policies in Beer Sheva

Oren Yiftachel, Ravit Goldhaber and Roy Nuriel

Space, Politics and (in)Justice/

L'espace, le politique et l'injustice

Mustafa Dikeç

\section{SÉGRÉGATION SPATIALE, ÉQUITÉ TERRITORIALE ET ACCÈS AUX RESSOURCES URBAINES}

Distance physique, proximité sociale

et inégalités devant le chômage.

Emre Korsu et Sandrine Wenglenski

Spatial Justice through Regionalism? The Inside Game, the Outside Game, and the Quest for the Spatial Fix in the U.S.

Karen Chapple et Edward G. Goetz

L'immobilité, facteur d'injustice spatiale?

Marie-Hélène BACQué et Sylvie Fol

\section{Postface}

Spatial Justice as Viewed from Gauteng, South Africa:

Professionals, Planning, Possibilities

Alan Mabin 


\section{Ségrégation et justice spatiale: perspectives}

$\mathrm{L}$

E TERME « SÉGRÉGATION » vient du verbe latin segregare qui signifie «mettre un animal à l'écart du troupeau». Transposé au champ urbain, il désigne un acte volontaire et est apparu initialement dans des travaux portant sur les ghettos juifs d'Europe orientale puis sur l'apartheid sud-africain, pour signifier l'idée de discrimination. Avec les tenants de la tradition sociologique de Chicago s'ancre l'intérêt des sciences sociales pour l'espace intra-urbain, et bientôt le concept tend à désigner plus largement le phénomène de division sociale ou ethnique de la ville ${ }^{1}$. Depuis la fin des années 1960 dans le monde anglo-saxon, et un peu plus tardivement en France, la question de la ségrégation urbaine tient une place considérable dans les études urbaines. Les approches de ces multiples travaux diffèrent: certains analysent les facteurs et les mécanismes de la ségrégation, d'autres mettent au point des critères et des outils de mesure quantitatifs, tandis que d'autres encore en étudient les impacts sur la vie locale des habitants et leurs destins individuels; les échelles retenues sont variées (de l'immeuble à l'agglomération en passant par le quartier); les villes étudiées diverses (de la petite à la grande ville, du Nord ou du Sud). Mais ces recherches partagent toutes l'idée que la ségrégation est par définition une injustice à combattre, sans démontrer le plus souvent les fondements de cette injustice ${ }^{2}$.

Rares ont été les auteurs à tenter d'expliciter les liens entre justice et ville, et plus spécifiquement entre injustice et ségrégation urbaine. Henri Lefebvre est l'un des premiers à le faire, indirectement, en proposant la

1. Roncayolo Marcel, «La division sociale de l'espace urbain: méthodes et procédés d'analyse ", in Bulletin de l'Association des géographes français, $\mathrm{n}^{\circ}$ 395-396, 1972.

2. Lehman-Frisch Sonia, «La ségrégation: une injustice spatiale? Questions de recherche ", in Annales de Géographie, n 665-666, 2009, p. 94-115. 
notion de «droit à la ville» en $1968^{3}$. Le droit à la ville, développe-t-il quelques années plus tard,

signifie le droit des citoyens, et des groupes qu'ils constituent (sur la base des rapports sociaux) à figurer sur tous les réseaux et circuits de communication, d'information et d'échanges. [...] Exclure de l'« urbain » des groupes, des classes, des individus, c'est aussi les exclure de la civilisation, sinon de la société. Le droit à la ville légitime le refus de se laisser écarter de la réalité urbaine par une organisation discriminatoire, ségrégative. [...] Le droit à la ville signifie donc la constitution ou reconstitution d'une unité spatio-temporelle, d'un rassemblement au lieu d'une fragmentation ${ }^{4}$.

Autrement dit, la ville juste est celle qui respecte le droit d'habiter la ville, c'est-à-dire le droit, pour tous ses habitants, de la produire, de se l'approprier, et de s'y rassembler: pour Henri Lefebvre, la ségrégation est fondamentalement injuste dans la mesure où elle fait obstacle au droit à la ville.

C'est aux États-Unis que les réflexions du sociologue français ont eu immédiatement le plus d'écho. Les années 1960 y sont en effet l'époque du Civil Rights Movement, de l'explosion démographique des ghettos noirs et de l'émergence des tensions qui conduiront aux émeutes dans de nombreuses villes-centre. Dans ce contexte, la géographie radicale se développe en faisant des questions urbaines dans la perspective de Lefebvre l'un de ses thèmes de prédilections, avec notamment William Bunge et ses « expéditions géographiques " à Détroit par exemple ${ }^{5}$, et David Harvey et son célèbre Social Justice and the City ${ }^{6}$. Tous deux invitent les chercheurs à ne pas se contenter de décrire les injustices associées à la ségrégation mais à s'engager concrètement au côté des citadins les plus défavorisés. Reste que dans les années 1980 et 1990, les recherches anglo-saxonnes sur la ville semblent dans l'ensemble s'éloigner des réflexions sur les notions de droit et de justice. Durant ces deux décennies, en France aussi, les travaux sur la

3. Lefebrve Henri, Le Droit à la ville, Paris, Anthropos, 1968.

4. Lefebvre Henri, Espace et Politique. Le Droit à la ville, $2^{\mathrm{e}}$ édition, Paris, Anthropos, 2000, p. 21-22.

5. Voir Merrifield Andy, « Le savoir situé et l'exploration: retours sur les “expéditions géographiques" de W. Bunge ", in Géographies anglo-saxonnes. Tendances contemporaines, Staszak Jean-François, Collignon Béatrice, Chivallon Christine, Debarbieux Bertrand, Geneau de Lamarlière Isabelle, Hancock Claire (dir.), Paris, Belin, « Mappemonde », 2001, p. 139-150.

6. Harvey David, Social Justice and the City, Baltimore, Johns Hopkins University Press, 1973. 
ségrégation urbaine se développent tout en reléguant toute référence à l'idée de justice au rang de présupposé implicite.

Depuis quelques années pourtant, en parallèle d'un développement de la réflexion philosophique anglo-saxonne sur le concept de justice (avec, après John Rawls ${ }^{7}$, les travaux de Iris Marion Young ${ }^{8}$, Martha Nussbaum ${ }^{9}$ et Nancy Fraser ${ }^{10}$ notamment) et dans un contexte urbain renouvelé, les géographes et les autres observateurs de la ville semblent se ressaisir de la question de la justice et de son rapport avec la ségrégation. Ce volume, le troisième de la collection "Espace et Justice ", ne se veut pas un énième ouvrage sur le thème de la ségrégation urbaine. Il a pour ambition de contribuer au renouveau des réflexions sur les liens entre ségrégation et justice en favorisant l'échange scientifique entre des chercheurs issus d'horizons géographiques et culturels variés, venus de France, des États-Unis, de Grande-Bretagne et d'Irlande mais aussi d'Afrique du Sud, d'Argentine et d'Israël. On soulignera toutefois la présence très majoritaire de textes traitant des pays du Nord par rapport au Sud (où pourtant les exigences de justice spatiale sont fortes, du fait notamment du poids des héritages coloniaux) à l'exception remarquable de deux pays émergents, l'Argentine et l'Afrique du Sud, où les violences politiques ont été si fortes que la justice spatiale est au premier plan des débats sur la ville et l'espace public. La forte prédominance d'auteurs de pays du Nord atteste d'ailleurs de la puissance de la diffusion des modèles en provenance de l'Amérique du Nord, et en particulier d'un renouveau de la circulation des idées entre les États-Unis et la France. On espère cependant que ce livre saura susciter des échanges avec des recherches menées dans des pays en développement, où la question de la ségrégation est un enjeu spatial et social considérable dans un contexte de forte croissance urbaine, et dont on ne peut que regretter l'absence ici ${ }^{11}$.

7. Rawls John, Théorie de la Justice, Audard Catherine (trad.), Paris, Éditions du Seuil, 1987.

8. Young Iris Marion, The Politics of Difference, Princeton University Press, 1990; Young Marion Iris, Inclusion and Democracy, New York, Oxford University Press, 2000.

9. Nussbaum Martha, Women and Human Development: The Capabilities Approach, New York, Cambridge University Press, 2000.

10. Fraser Nancy, Honneth Axel, Redistribution or Recognition? A Political-Philosophical Exchange, New York-Londres, Verso Books, 2003.

11. La revue Justice Spatiale|Spatial Justice (www.jssj.org), par exemple, s'est donné pour mission d'offrir une véritable plateforme internationale des réflexions sur l'articulation entre espace et justice. 
Ce livre souhaite de plus apporter des éléments nouveaux permettant d'éclairer les politiques urbaines qui, dans de nombreux pays, annoncent haut et fort vouloir remédier à la ségrégation parce qu'elle serait injuste par définition. Les auteurs des textes rassemblés ici ont donc été invités à se poser plusieurs questions ${ }^{12}$ : toute division socio-spatiale de l'espace - urbain en particulier - est-elle injuste? Quels sont les processus qui produisent de la ségrégation et en quoi sont-ils injustes? La situation de ségrégation produit-elle des effets injustes (les effets de lieu par exemple)? Symétriquement, l'objectif de la mixité socio-spatiale, souvent implicitement donné comme l'idéal de la ville juste, ne mérite-t-il pas d'être questionné? Enfin, la prise en compte de la mobilité n'impose-t-elle pas de repenser les relations entre justice et ségrégation?

La ségrégation est à la fois un processus et un état de division socio-spatiale de la ville, et la structure de l'ouvrage repose sur cette idée. Les deux premières parties s'intéressent à la ségrégation entendue comme processus: les auteurs y démontrent comment la ségrégation des espaces résidentiels (première partie) et des espaces publics (deuxième partie) est le résultat de forces économiques néolibérales injustes, de surcroît accentuées par les politiques urbaines menées localement, et comment les autorités légitiment précisément ces politiques avec des discours sur la justice sociale et la mixité. Les deux dernières parties interrogent la ségrégation en tant qu'état de division socio-culturelle de la ville pour observer si, en soi, elle est productrice d'injustice. S'il semble que la ségrégation prive les habitants concernés des moyens de se faire entendre politiquement, ce qui en retour renforce leur exclusion spatiale (troisième partie), les effets de la ségrégation sur l'accès à l'emploi sont en revanche moins évidents à mesurer (quatrième partie). Le volume s'achève, en guise de conclusion, sur une balade urbaine à travers trois villes, qui est l'occasion pour Alan Mabin de livrer ses réflexions sur la justice et la ville, en posant la question de l'importance des contextes nationaux et culturels dans l'articulation des questions de justice et de ségrégation.

12. Les textes rassemblés dans ce volume sont issus de l'atelier « Justice spatiale et ségrégation » du colloque international « Justice et injustices spatiales », université de Paris Ouest Nanterre La Défense, 12-14 mars 2008. Cet atelier a été organisé en trois sessions, animées par trois discutants que nous tenons à remercier ici: Stéphane Beaud (École Normale Supérieure), Marco Oberti (Observatoire Sociologique du Changement, Sciences Po) et Edmond Préteceille (Observatoire Sociologique du Changement, Sciences Po). 


\section{GENTRIFICATION, RÉGÉNÉrATION URBAINE ET URBANISME NÉOLIBÉRAL MONDIALISÉ}

L'étude de la gentrification et de l'homogénéisation sociale de certains espaces centraux dans les villes du Nord appartient à un champ de recherche très balisé, que cette dernière soit d'ailleurs admise ou contestée ${ }^{13}$. Miriam Chion à San Francisco, Stuart Hodkinson à Leeds, Andrew MacLaran, Sinéad Kelly et Paula Brudell à propos de Dublin nous montrent ainsi comment les politiques de régénération urbaine y ont amorcé et accompagné l'exclusion et le tri social, sur fond de transition post-fordiste, de spécialisation des centres-villes dans les activités tertiaires de loisir et de tourisme, mais aussi au rythme d'une spéculation immobilière et foncière effrénée. À San Francisco, ce processus conduit à l'éviction progressive des Afro-américains et des migrants hispanophones et philippins du centre. À Leeds et Dublin, la liquidation partielle du parc de logement social s'est accompagnée de l'éviction programmée des classes populaires des centres « régénérés ». Partout, les classes moyennes aisées partent à la (re)conquête des centres (c'est la "ville revanchiste", selon l'expression de Neil Smith ${ }^{14}$ ), investissant les friches industrielles, remodelant les espaces centraux à leur image et pour leurs usages consuméristes.

Si la gentrification n'est ni un processus, ni un concept nouveau, elle est cependant revisitée ici par des auteurs qui la replacent dans le contexte de la mondialisation. C'est cette dernière qui soumet les pouvoirs locaux à de fortes contraintes, auxquels ils sont au demeurant enclins à se plier; elle encore qui les dote de séduisants outils, de boîtes à idées issues des «best practices" internationales qu'ils adoptent pour mener la régénération urbaine. D'une part, la nature exceptionnelle des espaces centraux justifie le recours à des politiques territorialisées d'exception, au nom des « effetsvitrines $^{15}{ }$. D'autre part, à Leeds et Dublin, s'imposent des pratiques urbanistiques mondialisées relevant d'un « ethos entrepreneurial » et du modèle de la Ville entrepreneuriale, fondée sur des partenariats public-privé. Cette refonte de la gouvernance locale modifie les modalités et les finalités de

13. Préteceille Edmond, "La ségrégation sociale a-t-elle augmenté?», in Sociétés contemporaines, $\mathrm{n}^{\circ} 62,2006$, p. 69-93.

14. Sмiтн Neil, The New Urban Frontier. Gentrification and the Revanchist City, Londres, New York, Routledge, 1996.

15. Bénit Claire, Gervais-Lambony Philippe, «Globalisation as local political instrument in South African metropolitan area (Johannesburg and Ekhuruleni): the "poor" and the "shop window" ", in Transformation: critical perspectives on Southern Africa, n 57, 2005. 
l'action publique. Au nom de la croissance économique et pour le bénéfice des classes moyennes, les pouvoirs publics procèdent à la «commodification » de l'espace: les espaces centraux acquièrent une valeur marchande nouvelle et sont appréhendés et conçus avant tout en fonction de cette dimension économique, aliénant les biens publics (immobilier, espace...) au profit des intérêts de grands investisseurs privés. Dans le cas de San Francisco, Miriam Chion montre aussi que la gentrification est un produit de la mondialisation néolibérale: elle repose sur un urbanisme entrepreneurial (maximisation de la rente foncière, densification du centre...). Cependant, la norme néolibérale semble ici s'imposer, plus indirectement, à travers une dépolitisation des enjeux et une désocialisation des débats et ne semble pas être relayée aussi directement par l'État fédéral. San Francisco ne connaît pas non plus de crise du centre qui appellerait le recours aux recettes radicales retenues à Leeds et Dublin.

Ces modèles internationaux de gestion urbaine (déclinés techniquement avec des nuances en fonction des particularités des contextes nationaux et locaux) circulent de ville en ville, relayés et imposés en Irlande et en Grande-Bretagne par les injonctions des gouvernements centraux. La violence de la vague néolibérale thatchérienne et la radicalité des transformations observées à Leeds et Dublin expliquent sans doute les forts échos entre les deux textes et le fait que leurs auteurs recourent à un cadre théorique commun (la critique de l'urbanisation du néolibéralisme) et choisissent une posture idéologique très nettement influencée par la géographie radicale. En outre, Andrew MacLaran, Sinéad Kelly et Paula Brudell évoquent l'influence en Irlande des modèles importés de Grande-Bretagne (à Dublin, on s'inspire du modèle londonien de SoHo). La circulation des modèles urbanistiques entraîne celle des idées scientifiques.

Le succès de ces modèles contribue à promouvoir et à diffuser un projet urbain néo-hygiéniste et normatif, au nom d'une certaine image de la villecentre, mondialisée, uniforme, fréquentable et aseptisée. San Francisco s'affranchit de son image de ville cosmopolite tandis que Leeds et Dublin retravaillent leur passé de villes ouvrières. L’identité spécifique des centres semble s'évaporer. Assujetties au dogme néolibéral, ces villes excluent de plus en plus violemment de leurs centres les populations socialement faibles. C'est donc au nom de l'insertion des villes dans la mondialisation qu'est produite et légitimée l'injustice. Partout donc la gentrification reflète le succès d'un urbanisme néolibéral relevant de pratiques mondialisées ${ }^{16}$ aux effets partout injustes et similaires.

16. Brenner Neil et Theodore Nik, "Cities and the geographies of "actually existing neoliberalism" ", in Antipode, no 34 (3), 2002, p. 349-379. 
La transformation physique de l'espace, dont la dimension sociale est par ailleurs niée, obère tout débat sur la justice et engendre un fort sentiment d'injustice (analysé à Dublin par exemple). La participation publique et démocratique est court-circuitée, manipulée ou instrumentalisée, mais aussi intégrée de fait à ces nouvelles formes de gouvernance. Les auteurs mettent en garde contre la dépolitisation des enjeux liés à l'action urbanistique. À Dublin et à Leeds, ils évoquent la destruction du tissu social des centres. À San Francisco, Miriam Chion va jusqu'à pronostiquer l'érosion du capital spatial que constituent les centres-villes: la gentrification risquerait de se retourner contre ses propres auteurs en les privant de ce qu'ils sont venus chercher au centre (une ville vivante et métissée). Les stratégies de marketing urbain, en cherchant à altérer l'identité de la ville (gommer son identité ouvrière par exemple) peuvent aussi finir par altérer son image (l'image reconstruite et fantasmée de la ville animée, populaire et mixte). La gentrification engendrerait donc de l'injustice spatiale en excluant spatialement et en effaçant des identités urbaines indésirables, tout en produisant une autre image de la ville-centre, dérivée de son héritage populaire et cosmopolite, mais littéralement chimérique. D’ailleurs les urbanistes construisent un discours de légitimation similaire dans les différents contextes: la gentrification se ferait au nom de la « mixité sociale » et contre l'image du ghetto central et la faillite prétendument avérée du parc de logements public social. En fait, l'arrivée des classes moyennes au centre repousse et relègue les pauvres en périphérie des villes.

Pourtant, d'autres auteurs voient des effets positifs à la gentrification, à condition de se placer à l'échelle métropolitaine: la production de biens communs ou encore la redistribution fiscale qui peut résulter de l'augmentation de la valeur du foncier sont à leurs yeux les conditions d'une meilleure justice redistributive entre les quartiers. Mais Stuart Hodkinson, Miriam Chion, Andrew MacLaran, Sinéad Kelly et Paula Brudell privilégient l'échelle locale: ils s'intéressent aux effets de la gentrification sur le tissu spatial et social des quartiers. Ils n'abordent pas la question de la justice spatiale en termes d'équité comptable métropolitaine. Ils considèrent que la justice est une question de droit: droit d'accéder au capital spatial que constitue le centre-ville; droit à une ville mixte et moins ségréguée. Décalage de perspective scalaire pour des définitions conciliables de la justice, ou désaccord fondamental sur cette notion? Le débat reste ouvert.

Quoi qu'il en soit, en filigrane dans ces textes, se dessine une certaine idée de la ville juste, une image de la ville-centre mixte, populaire et vivante, très influencée par les appels à la reconnaissance d'un « droit à la ville » (selon 
Henri Lefebvre ${ }^{17}$ ou, plus récemment, Don Mitchell $\left.{ }^{18}\right)$, que l'on retrouve sous la plume de María Carman, Teresa Dirsuweit, Sarah Dooling et Gary $\mathrm{McDonogh}$, s'intéressant à l'espace public dans des villes mondialisées et de plus en plus injustes.

\section{ESPACES PUBLICS ET EXCLUSION SPATIALE}

María Carman, Teresa Dirsuweit et Sarah Dooling analysent les processus d'exclusion dont sont victimes certaines populations dans les espaces publics centraux. Elles montrent comment l'État, en exerçant sa « violence légitime ", exclut les sans abri à Seattle, les mendiants et autres «indésirables » à Johannesburg, les squatters à Buenos Aires. Se construisent ainsi des figures de la marginalité, par contraste avec les populations jugées légitimes et bienvenues dans ces espaces. Des représentations concurrentes de la vocation de ces espaces entrent en conflit, et celle des dominants triomphe. La ségrégation n'est plus seulement la mise à l'écart forcée d'un groupe social défavorisé, mais un processus d'auto-agrégation des plus riches, en vue de la «normalisation » et du « nettoyage » de l'espace public.

La figure de l'errant, du marginal, est stigmatisée aussi bien à Seattle que dans les villes émergentes du Sud et dans des contextes politiques très contrastés: dans un pays où la tradition d'urbanisme autoritaire perdure et où le traumatisme de la dictature militaire est immense, comme dans le contexte post-apartheid où la reconquête de la ville par les exclus d'hier est un enjeu central des politiques urbaines. Mais si le texte de María Carman sur Buenos Aires s'inscrit dans la très féconde tradition de recherche sur les évictions et les déguerpissements dans les villes en développement, tous les auteurs insistent sur l'importance, dans ce mouvement, de l'idéologie néolibérale mondialisée très normative et responsable de ces convergences. Comme pour la gentrification, ce processus mobilise des discours et puise des outils dans le champ des « best practice » internationales.

La ségrégation s'opère au nom de la protection ou de la mise en valeur de l'environnement urbain dans des villes qui se veulent mondiales, parfois au nom de la préservation des espaces "naturels». Par un détournement des combats environnementalistes internationaux, une certaine forme d'écologie et du développement durable, posées comme «bonnes » idéologies, sont mobilisées. Sarah Dooling propose de parler à ce propos

17. Lefebvre Henri, Espace et Politique. Le Droit à la ville, op. cit.

18. Mitchell Don, The Right to the City. Social Justice and the Fight for Public Space, New York-Londres, The Gulford Press, 2003. 
de « gentrification écologique ». Le rôle des grandes instances internationales en la matière est plus net que dans la gentrification des centres. Cette idéologie s'attaque finalement à l'idéal d'un espace public central, fait de liberté, de frottement, ouvert à toutes les pratiques ou presque et « appartenant » à tous.

Cette convergence explique sans doute en partie le regain d'intérêt, de la part de ces auteurs, pour le concept de «droit à la ville » que les transformations analysées écornent gravement. Ce «droit» n'est pas en soi nié, mais se trouve de fait limité et des discours de justification circulent qui sont désormais rôdés: en Argentine, l'illégitimité des déguerpis est opposée à la mémoire des desaparecidos (les " disparus », victimes de la dictature) à qui un parc urbain doit rendre hommage, précisément à l'emplacement occupé par des squatters. À Buenos Aires comme à Seattle, ces politiques hygiénistes et modernistes s'appuient sur le registre "civilisationnel » (comme le montrent María Carman et Sarah Dooling) pour justifier le nettoyage; à Johannesburg, elles convoquent le modèle du "new urbanism » (pourtant fort critiqué notamment en Amérique du Nord). Une nouvelle conception de l'espace public s'impose, au Nord comme dans des villes émergentes, défini comme un espace réservé et non propice à la démocratisation qui était pourtant tant attendue à Johannesburg par exemple. Les trois auteures soulignent l'absence de justice procédurale dans ce mouvement: absence de participation des résidants locaux ou des squatters, éviction des pauvres des débats sur la transformation des centres et sur la "gentrification écologique». Ces processus sont violents non seulement parce qu'ils procèdent à des expulsions manu militari, comme à Buenos Aires, mais aussi parce qu'ils sont anti-démocratiques et relèvent d'une forme de violence politique et morale.

En contrepoint, Gary Mc Donogh questionne l'idéal d'un espace urbain ouvert (reflet de la nostalgie d'une ville ante-mondialisée et d'un espace public fantasmé?). Il rouvre le débat sur l'espace public en le déplaçant là où on l'attend le moins, dans la suburbia nord-américaine. Produit direct $\mathrm{du}$ "White flight» (donc " racialement » homogène), de la désociabilisation et de la désolidarisation du reste de la ville, elle serait de plus privée d'espace public. La banlieue nord-américaine est ainsi, à tort selon lui, assimilée à toutes les ségrégations et à toutes les injustices. Au-delà du mythe de "l'anti-ville", l'auteur part à la recherche des espaces publics et de la mixité. Sa déambulation dans l'espace et le temps (il insiste sur la nécessité de repenser la suburbia dans sa mixité et sa profondeur historique) l'amène à réévaluer notre conception figée, voire fixiste, de l'espace public trop souvent assimilé à la monumentalité des places, par exemple dans la ville 
centre. Il traque sa présence dans les interstices suburbains (bibliothèques, parvis des églises, arrêts de bus...). En détrônant le centre-ville, espace privilégié de réflexion sur ces catégories, il nous invite à repenser ce que serait le véritable espace public dans la ville juste mondialisée.

Finalement, les victimes de la ségrégation le sont à double titre: d'une part, elles subissent l'éviction sociale et spatiale; d'autre part, elles peinent à se faire entendre, parce qu'elles vivent dans des espaces ségrégués. Elles doivent pour ce faire mener un véritable combat. Or dans les centres-villes, elles peuvent encore le faire. Presque tous les auteurs de la première et de la deuxième partie nous laissent entrevoir des formes de résistance, de coordination et de mobilisation, certes souvent embryonnaires et locales, mais parfois efficaces: lutte des locataires et renaissance de la mobilisation politique collective à Dublin et Leeds; résistance des classes populaires à San Francisco, qui négocient habilement pour imposer leur vision de la ville juste à l'occasion de "blind spots» dans la planification urbaine; difficile mobilisation des squatters de Buenos Aires; lente reconnaissance, pour les sans-abri de Seattle, d'un droit à rejeter les définitions normatives du logement et à être reconnus dans leurs souffrances spécifiques. La centralité semble décidément constituer une sorte de capital spatial: les exclus restent audibles en centre-ville parce que leur présence même y pose problème et y fait donc débat. En revanche, pour les invisibles des périphéries spatiales, la reconnaissance politique devient beaucoup plus difficile. C'est l'objet de la troisième partie.

\section{SÉgRÉgATION ET RECONNAISSANCE POLITIQUE}

La mondialisation des modèles de l'urbanisme néolibéral s'exprime également dans la large diffusion et le succès des idéologies participatives et dans la valorisation d'une gestion locale par les acteurs locaux. Cependant, bien que le principe de co-décision soit en théorie valorisé et le droit d'expression en apparence respecté, les groupes les plus démunis peinent à se faire entendre. La ségrégation va généralement de pair avec une absence de reconnaissance politique des populations qui la subissent. Elle a des effets sur les modalités de la représentation politique car elle prive les plus démunis de toute possibilité d'expression et renforce au contraire la voix des groupes les plus aisés. Dans son texte, Frédérick Douzet montre ainsi comment, dans le contexte californien, la ségrégation résidentielle conduit à l'injustice politique, qui vient renforcer, en retour, les inégalités socio-spatiales. L'auto-ségrégation des Blancs et des populations aux revenus les plus élevés accentue les inégalités créées par le système politique californien, et 
accroît la compétition entre les territoires au profit des groupes qui cumulent les ressources et le pouvoir politique. Ce processus permet aux populations aisées d'être gagnantes politiquement et d'imposer leurs intérêts par la voie électorale, ce qui a pour résultat d'aggraver encore la ségrégation et les inégalités inhérentes au système politique californien: la compétition entre territoires politiques qui en résulte profite aux groupes qui cumulent les ressources et le pouvoir politique. C'est donc au nom de l'idéologie de la participation et de l'autonomie politique locales que la ségrégation joue comme mécanisme excluant politiquement. Ainsi, l'exclusion politique s'appuie sur la ségrégation et en renforce les effets.

Les politiques urbaines peuvent, quant à elles, contribuer à renforcer ce mécanisme et à rendre encore plus difficile l'expression de certains groupes. Pour Mustafa Dikeç, la politique de la ville, telle qu'elle a été menée en France, a contribué à construire politiquement les banlieues comme des « restes» (remainders) de la société urbaine. En désignant les banlieues comme des territoires distincts et leurs habitants comme "différents », les politiques urbaines françaises ont consolidé un ordre spatial injuste et source de stigmatisation. Elles ont institué une démarcation radicale entre "l'intérieur » et "l'extérieur ", qui justifie des mesures répressives à l'encontre de ceux qui ne sont pas considérés comme des acteurs locaux à part entière mais seulement comme des "restes ». Si l'absence de reconnaissance politique issue de la ségrégation est préjudiciable aux groupes dominés, la reconnaissance en tant que telle ne constitue pas une garantie de justice spatiale. Au contraire, l'article de Oren Yiftachel, Ravit Goldhaber et Roy Nuriel analyse la reconnaissance comme un processus socio-politique aux multiples facettes, qui peut aller de la « reconnaissance hostile » à une « indifférence marginalisante ». À partir du cas de Beer-Sheva, en Israël, les auteurs montrent que les "gradients » de la reconnaissance sont liés à la fois aux transformations urbaines et à la place des différents groupes dans la ville, dans un contexte caractérisé par un " apartheid urbain rampant ». Là encore, la ségrégation conduit à limiter l'expression politique des groupes dominés.

Incapables de faire entendre leur voix politiquement, les plus démunis seraient donc condamnés à subir les effets injustes de la ségrégation, non seulement en matière de droits politiques, mais aussi en matière d'accès aux ressources urbaines. C'est l'objet de la dernière partie qui décline la question du lien entre ségrégation et justice spatiale sur un autre mode: celui des ressources urbaines et de l'équité territoriale. 


\section{SÉGRÉGATION SPATIALE, ÉQUITÉ TERRITORIALE ET ACCÈS AUX RESSOURCES URBAINES}

Les contributions de cette quatrième partie interrogent les effets de la ségrégation sur l'accès des groupes démunis aux ressources urbaines et plus généralement sur le destin de ces populations. Ce débat, né aux États-Unis et aujourd'hui largement diffusé en Europe, comporte deux volets: la question du spatial mismatch et celle des effets de quartier (neighborhood effects), qui ont en commun d'examiner certains effets de la ségrégation et de la concentration spatiale des «pauvres » et des minorités ethniques. Une partie des chercheurs participant à ce débat tente de montrer, dans la lignée des travaux de William J. Wilson ${ }^{19}$, que la concentration de populations défavorisées tend à redoubler les effets de la pauvreté, en privant ces populations d'accès aux ressources urbaines, à l'emploi et aux réseaux sociaux efficaces en termes d'intégration professionnelle et sociale. L'isolement spatial et social aurait ainsi pour conséquence d'accentuer les difficultés des individus concernés, que ce soit dans le domaine de la santé, de l'éducation, de l'emploi ou de la sécurité. Aux États-Unis, ces conclusions de recherche ont inspiré des politiques de déségrégation (expériences des Gautreaux ou programmes MTO), qui alimentent elles-mêmes de nouveaux travaux scientifiques s'efforçant d'en mesurer les effets sur les ménages relogés dans un quartier plus favorisé.

Témoignant de l'importation du débat en France, l'article d'Emre Korsu et Sandrine Wenglenski cherche à mesurer le rôle de l'espace et, plus précisément, de la concentration spatiale des catégories populaires dans l'accès à l'emploi. Il s'agit ici d'évaluer, dans le contexte de la région Ile-de-France, la pertinence des hypothèses justifiant les politiques de lutte contre la ségrégation, et donc de vérifier si les effets de quartier et le décalage entre les lieux de résidence et d'emploi des groupes les plus démunis (spatial mismatch) jouent un rôle dans l'accès à l'emploi de ces catégories. Les auteurs concluent, quoique de façon nuancée, que l'exposition durable à l'environnement des quartiers pauvres pénalise leurs habitants dans l'accès à l'emploi.

Sans tenir compte des évaluations mitigées des expériences de déségrégation, partout l'idéologie néolibérale tend à ériger la mobilité, quotidienne (pour l'accès à l'emploi) ou résidentielle (dans le cas des politiques de déségrégation), en norme qui s'impose aux habitants des quartiers pauvres

19. Wilson William Julius, The Truly Disadvantaged, Chicago, University of Chicago Press, 1987; WiLson William Julius, When Work Disappears, New-York, Vintage, 1996. 
comme à l'ensemble de la société urbaine. L'injonction à la mobilité est justifiée à la fois au nom de l'égalité des chances et de la responsabilité individuelle. C'est cette généralisation de politiques fondées sur l'égalité des chances (equality of opportunities) aux États-Unis que discute l'article de Karen Chapple et Edward Goetz. Visant à résoudre le problème de la pauvreté urbaine par une réduction des disparités entre villes-centres et banlieues, ces politiques d'équité régionale passent par le redéploiement spatial de la population, le déplacement des habitants des quartiers pauvres centraux vers la banlieue, ou des aides pour leur permettre d'accéder aux emplois suburbains. Pour les auteurs, ces politiques présentent le double défaut de ne pas s'attaquer aux injustices structurelles et de négliger la dimension des besoins des habitants, de leurs « capacités » (capabilities) et de leurs choix.

L'article de Marie-Hélène Bacqué et de Sylvie Fol questionne lui aussi les politiques fondées sur la mobilité, par dispersion des pauvres ou réduction de leur distance spatiale à l'emploi, afin de voir si elles sont aussi justifiables que les appels à la mixité sociale semblent le postuler. Les auteures montrent ainsi que l'injonction à la mobilité qui se généralise en Europe et aux ÉtatsUnis, tant dans les politiques de l'habitat que dans les politiques de transport, néglige le rôle du quartier comme lieu de concentration de ressources particulièrement précieuses pour des groupes qui en sont peu dotés. Rejoignant les conclusions de Karen Chapple et Edward Goetz, les auteurs en appellent à une prise en compte des choix des plus démunis, qui seule peut assurer l'objectif de justice spatiale.

\section{Conclusion}

Pour conclure, les contributions de ce volume suggèrent une première remarque, relative à la spécificité de la nature du corpus et aux représentations de la justice et de la ségrégation qu'elles mettent en œuvre. Il apparaît en effet que les contextes culturels dans lesquels ces textes ont été produits influencent clairement les perspectives des auteurs sur la question de l'articulation entre justice et ségrégation: c'est particulièrement net dans le texte sur Beer Sheva (où rôde manifestement le spectre de l' « ethnocratie ${ }^{20}$ » dans un contexte ethnico-politique pour le moins tendu), dans l'article sur Buenos Aires (où ressort le poids de la dictature militaire à travers la violence des déguerpissements), ou dans la contribution sur Johannesburg

20. Yiftachel Oren, Ethnocracy. Land and Identity Politics in Israel/Palestine, Philadelphia, Pennpress, University of Pennsylvania, 2006. 
(où apparaît l'obsession de l'espace public dans une ville condamnée pour sa fragmentation héritée de l'apartheid et sa « los angelisation »). C'est également vrai dans les analyses de la situation en Irlande et en Grande Bretagne (où est dénoncé l'impact de la puissante vague néolibérale qui a déferlé au Royaume-Uni avec la politique thatchérienne) ou aux États-Unis (où les débats tournent beaucoup encore autour de l'opposition villecentre/suburbs).

Quelles que soient les spécificités de leurs approches, ces textes ont cependant en commun le fait de laisser de côté certaines dimensions des relations entre ségrégation et justice ou injustice. Ainsi, dans certains quartiers ségrégués défavorisés, les habitants sont privés non seulement de ressources matérielles, mais aussi de ressources symboliques: de leur propre image et de leur propre identité, qu'ils se voient imposée, dévalorisée, de l'extérieur. Loïc Wacquant ${ }^{21}$ parle de "stigmatisation territoriale » pour désigner ce phénomène, et d'autres auteurs se sont intéressés aux réactions de crispation identitaire que cela provoque en retour ${ }^{22}$. Au-delà de cette question, quand on sait les formes spatiales ravageuses, individuelles ou collectives, que peut prendre dans les villes le ressentiment des habitants par rapport à leur situation de ségrégation, il paraît illusoire, comme en avertit JeanPierre Dupuy ${ }^{23}$, de prétendre penser la justice ou l'injustice sans prendre en compte les passions qu'elles suscitent immanquablement ${ }^{24}$.

De plus, que ce soit dans les processus qui la produisent ou dans ses effets, la ségrégation n'a été envisagée dans ce volume que comme source d'injustice spatiale et la plupart des textes n'ont guère questionné cette relation. Tandis que les catégories sociales les plus fortunées tirent un bénéfice évident de leur ségrégation volontaire (ou agrégation avec leurs semblables), comme l'ont bien montré les travaux de Monique Pinçon-Charlot et Michel Pinçon, il est pourtant légitime de se demander si le même processus d'agrégation peut avoir un effet positif sur les catégories sociales les plus démunies. Or dans la lignée des travaux de l'École de Chicago, certaines recherches ont révélé que les regroupements de populations pauvres

21. Wacquant Loïc, Parias Urbains, Paris, La Découverte, 2006.

22. BeAud Stéphane, $80 \%$ au bac... et après? Les Enfants de la démocratisation scolaire, Paris, La Découverte, 2002; Gervais-Lambony Philippe, Territoires citadins. 4 villes africaines, Paris, Belin, " Mappemonde », 2003.

23. Dupuy Jean-Pierre, "Inégalité, humiliation et ressentiment », conférence à l'ENS, Paris, octobre 2005.

24. Lehman-Frisch Sonia, "La ségrégation: une injustice spatiale? Questions de recherche ", op. cit. 
ou de minorités ethniques peuvent aussi avoir des vertus. Plusieurs chercheurs ont montré que le quartier, aussi pauvre soit-il, peut représenter un espace riche en ressources pour ses habitants ${ }^{25}$. Dans son «Éloge du ghetto ", Philippe Genestier ${ }^{26}$ plaide même pour le regroupement communautaire comme moyen de favoriser l'intégration des populations immigrées, l'existence de structures intermédiaires favorisant à ses yeux le processus d'acculturation.

Autant de questions qui vont à l'encontre des représentations communes et qui méritent d'être approfondies pour informer le plus précisément possible les politiques urbaines confrontées à la question de la ségrégation et visant à produire une ville juste. Ce sont ces politiques territoriales que le quatrième volume de la collection « Espace et Justice » va interroger à différentes échelles.

Sylvie FoL

Université Paris 1 Panthéon-Sorbonne, UMR Géographie-Cités

Sonia Lehman-Frisch

Université de Cergy-Pontoise, MRTE

Marianne Morange Université Paris Diderot, SEDET

25. Simon Patrick, « La politique de la ville contre la ségrégation, ou l'idéal d'une ville sans divisions ", in Les Annales de la recherche urbaine, n 68-69, 1995, p. 26-33; Lepoutre David, Cour de banlieue, Paris, Odile Jacob, 1997. Marie-Hélène Bacqué et Sylvie Fol, dans ce volume, rappellent les principaux travaux se situant dans cette perspective.

26. Genestier Philippe, «Éloge du ghetto, stéréotypes et termes repoussoir de la pensée urbanistique ", in Villes en parallèle, n 15-16, 1990, p. 312-329. 

GENTRIFICATION, RÉGÉNÉRATION URBAINE ET URBANISME NÉOLIBERAL MONDIALISÉ 



\section{Inner-City (Housing) Regeneration in Britain: Tackling Spatial Injustice or the New Urban Enclosures?}

They hang the man and flog the woman That steal the goose from the Common, But let the greater villain loose That steals the Common from the goose. Extract from English folk poem, circa 1764

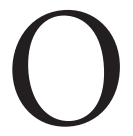

VER THE PAST THREE DECADES, cities in Western capitalist countries have been transformed under the policy prescriptions of "neoliberal urbanism”. Neoliberalism's emergence as a strategic capitalist response to the world profit crisis of the 1970s dramatically restored (finance) capital's power vis-à-vis labour. But the consequences of the restoration of market rule have extended far beyond the labour process into the very governance and production of urban space. Local authorities and the physical territories they managed have been gradually transformed from local providers of "services, facilities and benefits to urban populations" into urban entrepreneurs "embedded in a framework of zero-sum inter-urban competition for resources, jobs and capitals ${ }^{1 "}$. The re-imposition of the law of value has translated into urban and regional policy. Local authorities are pushed into mobilising "city space as an arena both for market-oriented economic growth and for elite consumption practices"." Gone are the days of bridging the spatial inequalities within national territories caused by capitalist uneven development by closing the gap between

1. Harvey David, "From Managerialism to Entrepreneurialism: the Transformation in Urban Governance in Late Capitalism", in Geografiska Annaler, vol. 71B, 1989, p. 3-17.

2. Brenner Neil, Theodore Nik, "Cities and the Geographies of 'Actually Existing Neoliberalism", in Antipode, vol. 34, 2002, p. 349-379. 
regions through the redistribution of wealth ${ }^{3}$. Instead, urban and regional policy is based on the neoliberal notion of "trickle down" that actively encourages the formation of urban growth poles around which other spaces must find a new, subservient role if they are to have any share of wealth created. It is therefore no coincidence that just as neoliberalism sees the abandonment by governments of the post-war commitment to social justice through redistribution, full employment and welfare (which of course varies enormously by country according to starting points and retreats), the urbanisation of neoliberalism sees the re-emergence of spatial injustice as a leading controversy of our times.

This paper critically explores how spatial injustice is both produced and challenged through the example of Leeds, a Northern English city heralded by municipal leaders, government, and academics as a role model of urban renaissance in former industrial cities. I will argue that the local authority's official aim of rejuvenating the city's deprived inner-city working class estates and neighbourhoods in order to "narrow the gap" with the prosperous urban core and Northern suburbs has little to do with spatial justice but is in reality a gentrification programme that aims to both privatise and demolish public housing in order to create new development opportunities for finance capital and in the process displace sections of the existing community in favour of a wealthier set of owner occupiers. By critically unpacking this central government regeneration scheme using private finance in Little London, a post-war public housing estate on the edge of the city centre, the paper argues that cities like Leeds are trapped in a "neoliberal straitjacket" that unless unstitched will eventually see the privatisation of all local public lands, assets and revenues and the creation of a neo-feudal local governance system run for, and increasingly by, corporate capital. As such, the neoliberalisation of cities is better understood as evidence of what have been called the "New Enclosures" with (global) capital once again in the ascendancy in its "totalising drive" to "commodify" and "enclose" all aspects of social life for the purpose of accumulation ${ }^{4}$.

3. Gonzalez Sara, "The North/South Divide in Italy and England: Discursive construction of regional inequality", in European Urban and Regional Studies, vol. 18-1, 2011, p. 62-76.

4. De Angelis Massimo, The Beginning of History: Value Struggles and Global Capital, London, Pluto Press, 2007; Midnight Notes Collective, "Introduction to the New Enclosures", Midnight Notes, 10, 1990, p. 1-9. 


\section{British Neoliberal Urbanism and the Role of Housing Policy}

Ever since the Labour government was bailed out of the sterling crisis in 1976 by the International Monetary Fund (IMF) in return for public expenditure cuts and the abandonment of the social contract with the trade unions, Britain has been a driving force of neoliberal policies at home and abroad. While much has been written in particular about the wholesale privatisation of state enterprises, monetarist policies to curb public spending, labour market deregulation and the dismantling of the welfare state under Thatcherism, the urbanisation of neoliberalism has received rather less attention. Since the early 1980s, successive governments under both Conservative and Labour rule have sought to transform the built environment of major cities for the purposes of speculative property investment, elite consumption and the growth of the finance and service sectors. To achieve this, local authorities have been forcibly turned into entrepreneurial actors competing aggressively for inward investment ${ }^{5}$.

Housing policy has played a central role in this paradigm shift. Following the election of Margaret Thatcher's Conservatives in 1979, public housing was targeted for privatisation and residualisation. Tenants were given the "Right to Buy" their council house at large discounts on the market value of their homes while some local authorities were given little choice but to sell off their housing stock to not-for-profit companies usually called Housing Associations $s^{6}$. This went hand in hand with the deregulation of protections and controls in both the private rental sector and the mortgage industry to re-insert housing into the private market, restoring the social power of private property and its disciplinary role in the labour market. These policies were largely retained by the incoming Labour government in 1997 so that since 1979 some 3.5 million homes developed and managed by local authorities for affordable rents have been sold off'. In the process, the

5. Harvey David, "From Managerialism to Entrepreneurialism: the Transformation in Urban Governance in Late Capitalism", in Geografiska Annaler, vol. 71B, 1989, p. 3-17.; BARnekov Timothy, Boyle Robin, Rich Daniel, Privatism and Urban Policy in Britain and the United States, Oxford, Oxford University Press, 1989.

6. Balchin Paul, “The United Kingdom”, chap. 14 in Housing Policy in Europe, Balchin Paul (ed.), London and New York, Routledge, 1996.

7. DCLG (Department for Communities and Local Government), "Live tables on social housing sales, Table 670 Social housing sales: Local authority stock sold through the right-to-buy scheme, by region", http://www.communities.gov.uk/ documents/housing/xls/table-670.xls accessed 30 June 2008; DCLG, "Completed LSVTs", http://www.communities.gov.uk/documents/housing/xls/completedlsvts. xls, accessed June 2008. 
role of local authorities has been decisively undermined, assets sold off for tax-cuts for rich, and more working class people have been brought into property ownership and mortgage debt, weakening socialist politics and strengthening the ever deregulated labour market and property industry. The remainder of public housing has become a tenure of last resort for those in dire need.

But the neoliberal assault on public housing is also intimately connected to the capitalist production of space in the city. The particular history of public house building in Britain has produced large concentrations of local authority estates in highly desirable suburban greenfield locations on commuter belts or on lucrative city centre sites next to prime office, residential and retail developments where land values far exceed the rents currently extracted from either public or private owners, what Neil Smith formulated as the "rent gap". Privatisation goes hand in hand with other state and corporate strategies to unlock, increase and exploit the land rents of these publicly-owned spaces. We can see how housing privatisation dovetails with what Harvey calls the "urbanisation of capital" in the Labour government's 2003 Sustainable Communities Plan that aims to both tackle entrenched poverty in the most deprived areas and encourage "a design-led 'Urban Renaissance' agenda fostering the physical, aesthetic and economic regeneration of all cities"'. To achieve Sustainable Communities, the government wants to improve the physical standards of all social housing through its Decent Homes programme and intervene in areas of so-called "housing market failure" by demolishing empty and undesirable housing. However, running through the various funding schemes to improve housing and neighbourhoods is a requirement to demolish working class housing - whether local authority owned or privately occupied - in order to create profitable opportunities in property speculation and public service delivery for finance capital, and to introduce a greater mix of tenure in the "failing communities" in order to help them rejuvenate - in other words, to spatially engineer communities in order to gentrify them and increase their

8. Smith Neil, "Toward a Theory of Gentrification: A Back to the City Movement by Capital not People", in Journal of the American Planning Association, vol. 45, 1979, p. 538-548.

9. Соцомв Claire, “Unpacking New Labour's 'Urban Renaissance' Agenda: Towards a Socially Sustainable Reurbanization of British cities?", in Planning Practice and Research, vol. 22, n 1, 2007, p. 1-24. 
prentable values ${ }^{10}$. We can see these processes at work through a case study of housing regeneration in the northern English city of Leeds.

\section{Housing Regeneration in Leeds}

Once a world manufacturing and trading centre for textiles and engineering, Leeds fell into relative decline during the international recession of the 1970s and 1980s. In past decade, however, the city has revived its fortunes as one of the fastest growing economies in the UK and is heralded as a role model of "urban renaissance". Previously abandoned industrial quarters have been revitalised, headed by speculative waterside developments, while the city centre has been restored as a leading retail and consumption zone $^{11}$. By the mid-1990s, however, Leeds had become dubbed by academics a US-style "corporate city ${ }^{12 "}$, and the City Council was increasingly criticised from grassroots and disadvantaged sectors of the city for failing to tackle the entrenched deprivation zones in the inner city and outer council estates.

The election of Labour in 1997 after 18 years of consecutive Conservative rule was heralded by previously critical commentators as marking a "change from a narrow entrepreneurialism to a more inclusive social agenda for the city $^{13}$ ". Recently, Leeds City Council has unveiled a regeneration strategy for its deprived inner urban areas aimed at "narrowing the gap between the most disadvantaged people and communities and the rest of the city ${ }^{14}$ ". No fewer than eight separate major housing-based regeneration initiatives have been launched since 1999 (see Figure 1) covering in the immediate southern, eastern and western hinterlands of the city centre that house the city's worst concentration of poverty, ill health, benefit-dependency and

10. Allen Chris, Housing Market Renewal and Social Class, London, Routledge, 2008.

11. Chatterton Paul, Unsworth Rachael, "Making Space for Culture(s) in Boomtown: Some Alternative Futures for Development, Ownership and Participation in Leeds City Centre", in Local Economy, vol. 19, n 4, 2004, p. 361-379.

12. Corporate City? Partnership, Participation and Partition in Urban Development in Leeds, Haughton Graham, Williams Colin (eds.), Aldershot, Avebury, 1996.

13. Haughton Graham, While Aiden, "From Corporate City to Citizens City? Urban Leadership after Local Entrepreneurialism in the United Kingdom", in Urban Affairs Review, vol. 35, n 1, 1999, p. 3-23.

14. Leeds City Council, Capital Strategy and Asset Management Plan 2004, Leeds, Leeds City Council, 2004. 
unemployment ${ }^{15}$. However, the City Council's regeneration strategy for its deprived communities and estates remains wedded to the neoliberal urbanist approach: all are public-private-partnerships, all are based on property-led development, and all involve the demolition of public housing and facilities and their replacement with private housing for market sale. In other words, regeneration means rolling out the city centre's gentrification frontier to its surrounding poor urban hinterlands. What follows is the story of arguably the most controversial of these regeneration schemes the Little London Private Finance Initiative.

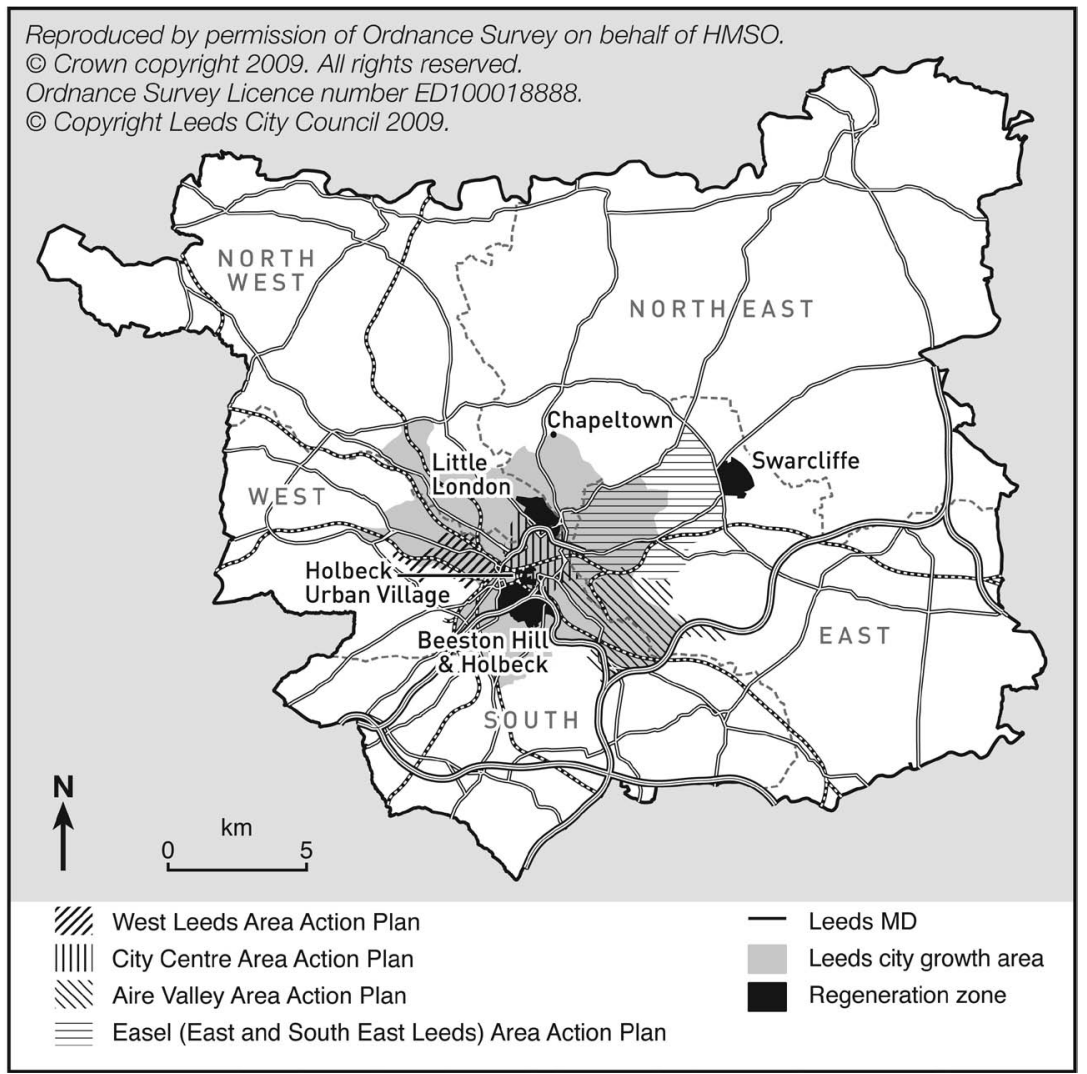

Fig. 1. Urban Regeneration Zones in Leeds

15. Leeds Initiative, Vision for Leeds, 2004-2010, Leeds, Leeds Initiative, 2004. 


\section{The Regeneration of Little London under the Private Finance Initiative}

Sandwiched in-between Leeds' booming central zone and its expanding university quarter, on the inner north-east rim of the city, lies Little London, a once popular modernist public housing estate with imposing high rise tower blocks, flat roofed maisonettes, terraced two-up two-downs, and semi-detached housing. By the late 1990s, Little London had become another victim of Thatcherism, gaining a dis-reputation as a "no-go area", full of drug-dealing, deprivation and physical decay. In summer 2001, Leeds City Council officially informed tenants of its intention to "regenerate" Little London using the government's housing PFI scheme to "improve the standard of homes, shopping areas and the wider environment" so that "residents have the quality of life they deserve ${ }^{16}$ ". However, when the Council unveiled its original 45 million pounds regeneration blueprint for Little London, the plan went far beyond simply refurbishing Council homes and improving the area for the people already living there. The Council's vision was to recreate Little London as a desirable "mixed community" that would both serve the city centre housing market and bring "the benefits of the city centre housing boom to Little London ${ }^{17}$. According to the plan, at least 150 council homes would be demolished on the most lucrative development land nearest to the city centre and the cleared sites would be sold to developers to build private housing for market sale. Three high rise blocks towards the city centre, containing 300 council flats, would also be sold off to developers to be refurbished as "middle market" homes for rent or sale. The rest of the estate would be given a radical facelift to fit in with the urban form of the city. In concrete terms, hundreds of poor families and individuals would be forced to leave their homes and community, with limited re-housing options and a derisory compensation package.

Armed with "evidence" from international property consultants Kings Sturge, Leeds City Council justified its strategy on the basis that the estate's social problems were linked to "specific property types" such as the high rise tower blocks and maisonettes, which had high turnover, low demand and problem tenants (in the shape of mainly young people with "challen-

16. Leeds City Council, Little London and Woodhouse Newsletter, Summer, Leeds, Leeds City Council, 2001.

17. Leeds City Council, Private Finance Initiative for Housing Revenue Account, Round 2. Expression of Interest, Little London, Leeds, Leeds, Leeds City Council, February, 2001. 
ging" and "anti-social behaviour" requiring welfare support) ${ }^{18}$. PFI would provide the "higher than average investment' required to deal with the flats' physical disrepair, and tenure diversification through private development would solve the social problems by helping to "maximise the market potential of the area", maintaining "demand for flats from a diverse customer group where applicants needing support do not predominate" (emphasis added) ${ }^{19}$. In other words, regeneration was about reconstructing the local housing market to enable house prices and rents to rise in line with city averages and reflect the true market value of their prime city centre location, while replacing a large number of the poor with a more economically desirable population.

Despite the Council bombarding the local community with pro-PFI propaganda and thinly veiled threats to vote "yes" or be cut adrift, the local community rejected the PFI scheme by $54 \%$ to $46 \%$ in the official ballot. The strength of feeling was reflected in the turnout - $67 \%$ - that dwarfed the average of $20 \%$ in local and general elections. Leeds City Council, however, had no intention of allowing such large amounts of investment to be lost. It refused to accept the ballot result, blaming the "misleading" propaganda of the anti-PFI campaign, and held a "fresh" ballot just two months later on what it called a "new' PFI scheme that no longer proposed to demolish two tower blocks (100 flats) as originally planned. Just to be sure, the Council redrew the boundaries of the proposed PFI scheme so that they cut out sufficient numbers of "no" voters identified on the edge of Little London. Inevitably, the result this time produced a "yes" vote for PFI, with $56.7 \%$ in favour but on a much reduced turnout (46\%). The progress of the Little London PFI scheme was then delayed again for three years due to the government's doubts about the affordability and manageability of the scheme, requiring a fresh consultation exercise in February 2006.

This time, however, the Council did not offer tenants a ballot, and rebranded its preferred scheme as the "Comprehensive Regeneration Option" with mention of PFI deliberately avoided where possible. The two towers previously "saved" were once again earmarked for demolition, but a new carrot was put forward: 125 new council homes would now be built to replace them. The catch was a reduction in both the number of council homes to be refurbished and maintained, and the frequency of major renewal, with the contract length reduced from 30 to 20 years. Surprisingly, in March 2008, the Council confirmed that, due to the "global credit 
crunch" and "housing market slowdown", it had abandoned its plans to sell off three tower blocks containing 297 flats to a developer and would instead retain and refurbish them as Council homes. This decision was also undoubtedly influenced by local resistance, which included a (failed) legal challenge and the emergence of a new tenants and residents group for the condemned blocks. At the time of writing, the PFI scheme, which was put out to tender in July 2007, is currently in the procurement phase with physical regeneration work not expected to begin until early 2010, a full nine years after Leeds City Council first applied to the housing PFI scheme.

\section{Private Finance Initiative and the Production of Spatial Injustice}

In many ways, Little London is a perfect example of "neoliberal urbanism" being transmitted through the specific context of Leeds. A victim of the roll back years, Little London's central geographical location has now left it "out of step" with the prosperous urban core and created a "rent gap" sufficiently large to invigorate local state and private actors to restructure the local housing market and release for capital accumulation the highervalue land and property through the PFI. At the same time, however, this analysis does not go far enough because it does not appreciate the decisive role played by the PFI in both shaping Leeds City Council's specific housing regeneration blueprint for Little London and placing powerful privatising pressures across the entire public services and assets of the city. To do so, we need to understand the neoliberal straitjacket of housing PFI and how it has operated in Little London.

Under PFI, the entire process of financing and carrying out the design, the building, and the operation of public infrastructure (that is, the physical facilities, not the actual frontline service itself) is packaged into a lucrative long-term contract (normally 20 to 30 years). These are then bid for by private consortia (each typically comprising a construction firm, a facilities management company and a bank to finance the scheme). The winning PFI consortium will receive regular performance-related payments that cover the entire cost of the scheme and include a large profit for the companies involved, estimated at between $7 \%$ and $20 \%$ of the total payment ${ }^{20}$.

20. Spoehr John, Whitfield Dexter, Sheil Christopher, Quiggin John, Davidson Kathryn, Partnerships, Privatisation and the Public Interest: Public Private Partnerships and the Financing of Infrastructure Development in South Australia, Adelaide, University of Adelaide, Public Service Association of South Australia, 2002; Unison Scotland, At What Cost? A Unison report on the aggregate costs of PFI/ PPP projects in Scotland - and some suggestions on a way forward, Glasgow, Unison Scotland, 2007. 
There is now a wealth of documented evidence exposing the controversies and problems of the PFI across the public sector, particularly in hospitals and IT systems: it is proven to be on average 30\% more expensive than publicly financed projects because of the higher cost of commercial borrowing, and is notorious for escalating project costs and delays, poor quality building work, service failure, worker exploitation, a lack of accountability and corporate profiteering ${ }^{21}$. However, while the costs and risks of the PFI are of major concern, the real significance of PFI lies in the broader social restructuring processes it is helping to unleash.

To summarise, there are three main neoliberal components of housing PFI. The first is the set of very specific market-friendly policies such as gentrification and privatisation that local authorities must follow in designing their regeneration scheme. Detailed examination of government guidance reveals the strong top-down pressure on local authorities since 1998, and especially after 2003 with the sustainable communities plan, to devise housing PFI schemes that create "mixed communities" (read: gentrification) and "tenure diversification" (read: demolition/privatisation of council housing). While the government's language reads flexible, it is in reality a highly prescriptive framework to ensure that up to 410 local authorities potentially competing for just a handful of places on the PFI programme come up with the most "attractive" schemes that will satisfy the Treasury and entice the private sector (emphasis added):

The Office would like to see schemes, which are mixed developments... The standard approach... takes in new build, upfront refurbishment or demolition and reprovision works, ongoing housing management services, and repairs and maintenance services... Any further benefits of the PFI bid should be described such as tenure diversification and the creation of additional public and private housing funded outside housing PFI credits ${ }^{22}$.

Leeds City Council has followed these guidelines to the letter. Using a matrix of refurbishment, selective demolition, privatisation and new private housing development, the regeneration approach is a deliberate strategy to reduce both the amount and proportion of rented public housing in favour of private housing tenures, and in turn produce an identical transformation in the class composition of the local community away from the

21. Whitfield Dexter, Public Services or Corporate Welfare: Rethinking the Nation State in the Global Economy, London, Pluto Press, 2001.

22. ODPM (Office of the Deputy Prime Minister), Private Finance Initiative Schemes for HRA/Non-HRA Housing Guidance for Authorities Making Proposals, London, The Stationary Office, 2005. 
urban poor in favour of middle-class homeowners and upwardly mobile private tenants. Importantly, this has not only been a top-down process. As Leeds City Council ${ }^{23}$ admitted to tenants in a moment of rare candour, housing PFI offered it the "capacity to 'design out'...the most needy people" from the estate, which it believed would enable the community "move from the current "crime and grime" focus towards a more aspirational agenda". In other words, government policy empowered the Council to demolish out some of the undesirable tenants and build in the private residents it wanted to attract as part of its city centre regeneration drive.

The second neoliberal component of housing PFI is the specific financial system that local authorities must adopt. In short, the government provides an annual "capped" subsidy ("PFI credits") to cover the "capital cost" of the PFI scheme, while the local authority must fund the day-to-day operational costs of the 20 or 30 year contract as far as possible from within existing local budgets that are already extremely tight under neoliberal austerity. This financial model economically incentivises local authorities in the first instance to demolish public housing and create development sites to sell on in order to finance the proposed improvements to the PFI regeneration zone. Because of the hugely complex process of creating an output-based contract that incorporates all of the predicted costs and revenues for each financial quarter (e.g. general inflation, building costs inflation etc.) of a 30 year period, any delays before a contract is signed have potentially huge additional cost implications due to the higher predicted future cost scenarios of the later start and completion date. Any escalating costs of PFI contracts become the responsibility of the local authority, placing it under constant pressure to "transfer resources from other parts of the housing budget to pay for its PFI obligations $s^{24 "}$. Once that revenue stream dries up, the local authority may look to cut other budgets or outsource some services to the private or voluntary sector.

For the Little London scheme, the annual repayment to the PFI consortium is currently expected to be 9.443 million pounds for the duration of the 20 year contract, an eventual total cost to the public purse of 211.9 million pounds. While the government will contribute just over three-quarters of these costs, some 1.52 million pounds must be found every year by Leeds City Council for 20 years. In the first instance, this must come from its

23. Leeds City Council, Minutes of Little London Regeneration Task Group, 28 November, Leeds, Leeds City Council, 2005.

24. Hodges Ron, Grubnic Suzana, "Public Policy Transfer: the Case of PFI in Housing", in International Journal Public Policy, vol. 1, nº 1/2, 2005, p. 58-77. 
housing budget, and then from "other resources" as needed. This long-term contractual commitment to provide a guaranteed revenue stream to the PFI consortium has already shaped the amount of council housing included in the refurbishment and maintenance scheme. The Council has had to balance the long-term revenues provided by tenants' rents with both longterm risks (i. e. whether there will be sufficient demand for council housing in the future) and short-term income generation opportunities to reinvest in the PFI scheme (i.e. selling off public land for private development). This has resulted in the Council creating a number of development sites (some that involve clearing existing council homes) within the Little London PFI zone that it will sell for mainly private housing development. It has also reduced the proposed contract length from 30 to 20 years in order to minimise the long-term financial risks to the Council ${ }^{25}$. This shows how PFI financing offers both carrots and sticks to councils aimed at privatising public assets and reducing service provision.

The third component is the "locking in" of market forces and interests into the eventual PFI scheme through the exposure of the public sector throughout the design and procurement phase to the overcrowded (and thus very competitive) buyers' market for PFI contracts. When the future uncertainties and risks generated by fluctuating performance and forecasts of economic growth and financial markets are added in, this environment usually creates an evolution in a scheme's design and features in the direction of generating greater profitability opportunities and away from social provision, high quality service performance and workers' pay and conditions. For example, the spectre of these risks being locked into a 20-30 year contract have a strong influence on the kind of housing scheme the local authority will design, in order to minimise the risks both to itself and the private sector in order to make the scheme attractive in a competitive market. These "carrots" to the private sector usually involve what Whitfield" ${ }^{26}$ calls the "privatization of the development process" through land and property deals that enable capital to gain control of "surplus land and buildings such as school playing fields, vacant land, empty hospital buildings and so on for property development".

Confidential council documents reveal just how far the Council went in internalising the logic that the regeneration of Little London using PFI was

25. Leeds City Council, Little London Private Finance Initiative: Outline Business Case, Leeds, Leeds City Council, 2006.

26. Whitfield Dexter, Public Services or Corporate Welfare: Rethinking the Nation State in the Global Economy. London, Pluto Press, 2001. 
ultimately dependent on "the private sector's willingness to invest in the $\operatorname{area}^{27}$. In 2005, following another round of market testing, Council officers argued for the need to re-scope the PFI scheme to "create a more favourable investment opportunity ${ }^{28}$ ". In other words, the needs of capital accumulation were prioritised above the social needs of the community. This constant exposure to market forces has so far seen the Little London regeneration plan change seven times in seven years as council planners and housing officers have been forced to come up with increasingly "bolder proposals to create mixed tenure; larger development sites to create 'critical mass '29". Worryingly, documents released under the Freedom of Information Act show that the Council has a radical "plan b" if the private sector is eventually not satisfied with the current proposals: to demolish up to six more tower blocks on the estate ${ }^{30}$.

\section{Wider Implications: the New Urban Enclosures?}

The implications and effects of these three driving forces of neoliberalisation extend way beyond any single PFI scheme - they encompass the entire local public sphere. By entering into long-term, legally binding contractual commitments to make regular profitable payments to capital, the local authority is forced to adopt an increasingly entrepreneurial and commercial understanding of its entire portfolio of services, land and property holdings. It employs financial consultants like KPMG and Price Waterhouse Coopers, who have already earned millions of pounds from government and private sector contracts to help set up PFI contracts, to now help them make efficiency savings (cuts in services and staff) and offload "surplus assets" (sell off public buildings, spaces and land) to capital in order to attract scarce resources to their city. All local public services and buildings thus become at risk of being sold off, creating strong incentives for the public authority to enter into yet more PFI contracts in order to raise short term finance for vital public investment, simply strengthening and speeding up the vicious circle.

27. Leeds City Council, Report of Chief Regeneration Officer to Neighbourhood and Housing's Departmental Management Team, Little London Project Update, Leeds, Leeds City Council, 12 April 2005.

28. Ibid.

29. Ibid.

30. Leeds City Council, Little London Private Finance Initiative: Outline Business Case, op. cit. 
This is where the seminal work of Dexter Whitfield comes into its own. He explains how once local authorities are locked into this path an ever increasing proportion of public budgets will be committed to financing PFI schemes leaving an ever smaller proportion of revenues to deal with non-PFI services, "thus limiting an authority's ability to respond to changing social needs and priorities ${ }^{31}$." At the end of the long-term contract, instead of reverting to public ownership and management as they should, the assets that have been built and maintained under PFI will probably either be subject to another PFI contract or will be "sold at residual value to the private sector ${ }^{32}$. This is because after 20 to 30 years, public bodies may not have the capacity or political commitment to take the facilities back. By this time, Whitfield predicts that the artificial separation of public services into "core" and "non-core" categories will have been once again closed due to corporations' pressure on government to allow them to expand their business interests further into publicly-funded, guaranteed and underwritten new profit streams. Eventually, Whitfield foresees that the many PFI/ PPP schemes across a city will be gradually become centralised under a small number of parent companies through buy-outs and mergers, leading to contract rationalisation and job losses, and, ultimately, a publiclyfinanced but unaccountable "company town":

$[\ldots]$ the company town is reemerging, not dominated by one industry or family, but by business elites through their involvement in regeneration, partnerships, outsourcing and sponsorship of arts and culture. The local state transfers assets and defers to the needs of and interests of the business sector first and foremost. Local authorities are increasingly corporatised and influenced by business elites ${ }^{33}$.

Consequently, following the insights of autonomist Marxists such as Midnight Notes Collective ${ }^{34}$ and Massimo De Angelis ${ }^{35}$, it is possible to see the contemporary privatisation of British cities as both a return to, and a continuation of, the processes of "enclosures" from the late 1400s to the $19^{\text {th }}$ century that expelled the vast majority of people from the land and transformed various forms of property (Church, state, feudal, clan and commons) into private ownership, "separating" the producer from the means

31. Whitfield Dexter, Public Services or Corporate Welfare: Rethinking the Nation State in the Global Economy, op. cit.

32. Ibid.

33. Ibid.

34. De Angelis Massimo, The Beginning of History: Value Struggles and Global Capital, London, Pluto Press, 2007.

35. Ibid. 
of (re)production and creating a population of workers with only their labour to sell to survive ${ }^{36}$. Instead of seeing what Marx called the "primitive accumulation" of capital as taking place at the beginning of capitalism, these theorists argue that the process of enclosure - that is the separation, expropriation and privatisation of resources from people - is the process of capital accumulation, a process with "totalising drives" to colonise all aspects of social life for profit in response to the constant battle with "other forces that act as a limit on it", giving rise to what De Angelis ${ }^{37}$ calls "value struggles" (or class struggle):

It is either capital that makes the world through commodification and enclosures, or the rest of us - whoever is that "us" - that makes the world through counter-enclosures and commons $s^{38}$.

In its drive to accumulate, "capital has to devise strategies of enclosures, either by promoting new areas of commodification vis-à-vis resistance, or by preserving old areas of commodification vis-à-vis ex novo attacks that it faces by 'commoners'39'. Public management and private finance systems like PFI can thus be understood as consciously designed mechanisms to build in and embed semi-automated processes of enclosure into the financing and delivery of local public services. These processes create a dialectical interaction between different dynamic forces of commodification, financialisation, privatisation and competition, forming a vicious circle that makes the functional logic of the local state to "enclose" more and more of the public sector - and the city itself - for capital.

In the case study of Leeds, the process begins in Little London with the very real enclosure of housing and land previously held in a form of municipal common ownership, and the direct replacement of subsidised and protected rented housing based on "need" with private market housing for sale based on ability to pay. While those social tenants who have been forced to leave their homes are not immediately flung onto the private market due to the Council's guarantee to re-house, the net reduction in the supply of public housing in a city with a waiting list of over 30,000 people does mean that more people elsewhere will be in effect be separated from these scarce commons and forced into the private sector. This process of separation and market capture is reinforced by the accompanying gentrification and marketisation of Little London's local housing supply, which pushes

36. Marx Karl, Capital, Volume 1, London, Penguin Classics, 2004.

37. Ibid.

38. Ibid.

39. Ibid. 
up rents and property prices, encouraging council tenants to take up their discounted Right to Buy in order to make a large profit in the future, meaning yet more public housing and land is enclosed.

The enclosure dynamo does not stop here. By entering into a long-term contract with capital, Leeds City Council is legally bound to honour a financing model in which the government's contribution remains "fixed" throughout. This means that in an already fiscally austere environment for local authorities, the Council must shoulder the rising costs of the scheme as they occur, regardless of other commitments or local needs, by transferring revenues from other budgets and selling assets from elsewhere in its portfolio to meet the PFI repayments. If this was the only PFI scheme that Leeds City Council had to finance, then the rising costs would probably be quietly absorbed within a huge local authority complex employing approximately 35,000 people and delivering over 500 services to 730,000 people on an annual budget of over 1,000 million pounds with a huge property and land portfolio valued at 3.33 billion pounds ${ }^{40}$. However, this is not the only PFI scheme - in its push to meet government targets and attract as much extra investment as possible for its regeneration schemes and public services modernisation, Leeds City Council has become the leading (and award-winning) local authority for PFI contracts in the UK. In total, Leeds has successfully attracted more than 1 billion pounds worth of "PFI credits", with a further 550 million pounds awaiting decision, covering street lighting, new schools and leisure centres, social housing, joint services and waste management ${ }^{41}$. Given that the full costs of PFI are usually between two and three times the headline figure and increase over time, the City Council could eventually be liable for at least 1 billion pounds in PFI repayments over the next 15 to 30 years, and on current trends, the Council could have acquired a further 10-15 billion pounds worth of PFI schemes over this period, meaning an additional $£ 2-3$ billion pounds in debts to PFI consortia lasting well past the year 2050.

The implications of having to meet these huge future commitments in a context of growing fiscal austerity under neoliberalism could be catastrophic for the local public sector in Leeds. The Council would have to raid other budgets or sell off more public assets to ensure that all of its PFI

40. Leeds City Council, Capital Strategy and Asset Management Plan 2007/08, Leeds, Leeds City Council, 2007.

41. Leeds City Council, "Report of the Deputy Chief Executive to Executive Board, Progress Report on the PPP/PFI Programme in Leeds", Leeds, Leeds City Council, 17 October 2007. 
schemes were financially solvent. This may start with service cuts and property sales from within the physical PFI zone, spreading out to general budgets and assets associated with the particular scheme (e.g. housing or education). Then might come the cuts in grants for the arts and culture as well as non-frontline services, but as the liabilities stack up, the process may gradually encompass health and education services, and the closure and sale of community centres, schools, libraries, art exhibition premises, museums, leisure centres, prestigious listed buildings and so on in order to create development or investment opportunities for developers and real estate corporations. Like climate change, this is not some far distant dystopia - it is already happening. Since 1998, Leeds City Council has operated an increasingly sophisticated Asset Management System designed to, amongst many things, identify a continuous supply of "surplus property" to sell off and reinvest the proceeds into the Council's Capital Investment Programme, which is of course increasingly dominated by PFI schemes and their rising costs. As a result, since 2002, Leeds City Council has sold off more than 130 million pounds worth of public property and land, and forecasts that by 2012 a further 105 million pounds of assets will be privatised $^{42}$. These "surplus assets" have so far included: several schools and playing fields, hundreds of council homes, some 22 community centres and 16 public toilets. However, the Council own figures suggest that no matter how much it raises in capital receipts from selling off its assets, there is always an annual shortfall in its capital investment commitments. This transmits into increased targets for raising additional funds from privatising council assets. For example, up to 6000 council houses are currently earmarked for demolition to sell development sites to private developers as part of the city's regeneration strategy for deprived areas ${ }^{43}$.

\section{Towards a Spatial Justice Politics?}

Unless there is a change of direction soon, it is a real possibility that Leeds will gradually become completely "enclosed" with all public services, spaces and assets owned and controlled by global corporations and citizens at the complete mercy of the "market". We cannot imagine the possible night-

42. Leeds City Council, Capital Strategy and Asset Management Plan 2004, op. cit.; Leeds City Council, Capital Strategy and Asset Management Plan 2005, Leeds, Leeds City Council, 2005; Leeds City Council, "Report of the Deputy Chief Executive to Executive Board, Progress Report on the PPP/PFI Programme in Leeds", Leeds, Leeds City Council, 17 October 2007.

43. Outside, Leeds Housing Market Assessment 2007 - Summary, Leeds, Leeds City Council, 2007. 
mare scenarios of spatial injustice that this would bring. Yet, in the gloom, there is still hope. The very material processes of enclosure - school closures, housing demolitions, public space erosion - provoke very real material responses in the form of popular opposition and resistance seeking to "reclaim social spaces... and turn them into spaces of commons ${ }^{44}$ ". In Little London, a small but committed group of tenants has questioned and fought the Council's PFI scheme since it was first unveiled in 2001. While they have narrowly failed to stop the PFI scheme, their resistance has forced the Council to make decisive concessions, such as the like-for-like replacement of demolished council homes with social rented housing, and the retention of 300 flats originally scheduled for privatisation. In other words, they have saved some 430 public housing units when previously told that there was no alternative. Moreover, their dogged resistance has sparked the formation of a growing city-wide housing movement, supported by local academics and trade unionists, that aims to learn from the Little London experience and fight the planned demolitions, privatisations and gentrification policies across Leeds ${ }^{45}$. This has the potential to link up with the revived Leeds Tenants' Federation as well as the renewed squatting and social centre movement that in other cities has seen the occupation and reopening of public swimming pools, community centres, schools, abandoned warehouses and so on ${ }^{46}$.

While these struggles remain marginal and marginalised for the time being and will require a major and sustained organising and educational drive by progressive forces to reverse the current trends, there is hope that capital will never be able to exercise the sole "right to the city". Without being overly prescriptive, a strategy for uniting people around a common agenda for spatial justice might, as a starting point, set out to build a broadbased campaign of tenants, home owners, community activists, trade unionists, existing councillors, anti-capitalists, academics and others. This campaign would push for affordable, tenant-controlled public rented housing as part of anti-poverty coalition at the local and regional level. Buil-

44. De Angelis Massimo, The Beginning of History: Value Struggles and Global Capital, London, Pluto Press, 2007.

45. See www.handsoffourhomes.org.uk.

46. Hodkinson Stuart, Chatterton Paul, "Leeds: an affordable, viable sustainable, democratic city?", in The Yorkshire and Humber Regional Review, vol. 17: 2, 2007, p. 24-26 (http://www.autonomousgeographies.org/files/sustainable_city. pdf); Mooney Gerry, And Fyfe Nick, "New Labour and Community Protests: the Case of the Govanhill Swimming Pool Campaign, Glasgow", in Local Economy, vol. 21, n 2, 2006, p. 136-150. 
ding unity could be achieved by a dual commitment, on the one hand, to the defence of existing public housing provision from privatisation, as well as homeowners and tenants under threat of compulsory purchase or eviction in regeneration areas and, on the other hand, to put forward alternative solutions and visions of the city that support common ownership and democratization. Empty or misused private land and property could be occupied to provide free squatted housing, and public meetings would be held to highlight the contradiction between private property and housing waiting lists, demonstrating the power of everyday commons in praxis. The long-term aim of such a strategy would be to create a critical mass of diverse strategic and tactical interventions, from blocking privatisation and gentrification, stopping the closure of community facilities, and occupying land to winning seats on the local council. These tactics would force periodic concessions from state and capital, and help to re-energise the housing campaign and keep it going until such point as it reached an as-yet undefined future guided only by principles of the commons.

Stuart HodKInSON ${ }^{47}$

School of Geography, University of Leeds

47. The author is grateful to the ESRC (RES-000-23-0957) for funding this initial research and the British Academy (PDF/2007/75) for allowing me to continue this engagement. I would also like to thank Ed Soja, Huw Jones, Sara Gonzalez, Jenny Pickerill and Paul Waley for their comments, and especially the tenants of Little London, Leeds, for their input and collaboration. 

Dublin's Neoliberal Agenda and the Social Cost of Entrepreneurial Planning

Projet néo-libéral et coût social de l'urbanisme entrepreneurial à Dublin 


\section{Dublin's Neoliberal Agenda and the Social Cost of Entrepreneurial Planning}

$\mathrm{T}$

HIS PAPER REVIEWS the manner in which a neoliberal political agenda emanating from central government has increasingly infused Irish urban policy and created an entrepreneurial localauthority culture in which urban planning and regeneration policies have been pursued in a highly contentious manner. Specifically, it examines the ways in which the functioning of local-area planning, public-private partnerships in social-housing regeneration and urban gentrification strategies have operated in inner Dublin to exacerbate existing problems rather than addressing and mitigating them.

Although the paper inherently concerns issues of distributional significance with regard to both class and geography, resulting from the wielding of class power through the aegis of the capitalist state, it intentionally avoids couching the discussion within a context of spatial or territorial "justice". Specifically, the engagement with such concepts is deemed inappropriate to the achievement of a materialist analysis of the consequences of state activity as the concept of "justice" in the abstract is one that emanates from bourgeois ideology itself and is closely linked to a protean moralistic ideology of "rights". Thus, in developing his materialist critique of legal forms, Pashukanis ${ }^{1}$ noted that the definition of humans as legal personalities and bearers of "rights", rather than possessors of customary privileges, coincides with and is necessary for social production to be pursued as a process of general commodity production. Thus, "only in bourgeois capitalist society where the proletarian figures as a subject disposing of his labour power as a commodity, is the economic relation of exploitation mediated legally, in the form of a contract ${ }^{2 \prime}$. It is therefore the commodity form which produces the legal form and "the legal relation between

1. Pashukanis Evgeny, Law and Marxism: a General Theory, London, Ink Links, 1978.

2. Ibid., p. 45. 


\section{Projet néo-libéral \\ et coût social de l'urbanisme entrepreneurial à Dublin}

C

ET ARTICLE ANALYSE la manière dont le projet politique néo-libéral porté par le gouvernement national en Irlande influence de plus en plus fortement les politiques urbaines, créant une culture entrepreneuriale au sein des pouvoirs locaux qui se traduit par une planification urbaine et des politiques de renouvellement urbain très contestables. Nous mettons en particulier l'accent sur le fait que, dans le centre-ville de Dublin, le fonctionnement de la planification à l'échelle locale et des partenariats public-privé en matière d'amélioration de l'habitat social, ainsi que les stratégies de gentrification, ont exacerbé les problèmes existants plutôt qu'ils ne se sont employés à les atténuer.

Bien que ce texte traite intrinsèquement des questions de distribution sociale et géographique résultant de la domination de classe sous l'égide de l'État capitaliste, c'est délibérément qu'il évite de formuler la discussion en termes de « justice » spatiale ou territoriale. Nous considérons en effet que l'utilisation de tels concepts n'est pas pertinente dans le contexte d'une analyse matérialiste des conséquences des actions de l'État, puisque le concept de "justice » émane précisément de l'idéologie bourgeoise et est intimement lié à l'idéologie moraliste protéiforme des «droits». Ainsi, développant sa critique matérialiste des formes légales, Evgeny Pashukanis ${ }^{1}$ écrit que définir les hommes comme des individus légaux et porteurs de «droits » plutôt que comme les bénéficiaires de privilèges coutumiers revient à (et est nécessaire pour) concevoir la production sociale comme un processus de production de marchandise. Ainsi, « la société capitaliste bourgeoise, dans laquelle le prolétariat dispose de sa force de travail comme d'une marchandise, est la seule où la relation économique d'exploitation est légitimée légalement par des contrats ${ }^{2} »$. C’est donc la forme marchande

1. Pashukanis Evgeny, Law and Marxism: a General Theory, Londres, Ink Links, 1978.

2. Ibid., p. 45. 
the subjects is simply the reverse side of the relation between the products of labour which have become commodities ${ }^{3 "}$.

This argument was elucidated further in Arthur's introduction to the 1978 edition of Pashukanis's work:

It is only in the conditions of commodity production that the abstract legal form is necessary - it is only there that the capacity to have a right in general is distinguished from specific claims and privileges. It is only the constant transfer of property rights in the market that creates the idea of an immobile bearer of these rights. Indeed, the abstract capacity of everyone to be a bearer of property rights makes it difficult for bourgeois thought to see anything else than subjects of rights; legal fetishism complements commodity fetishism ${ }^{4}$.

\section{BACKGROUND}

Following Irish entry to the European Economic Community in 1973, the Irish economy underwent major restructuring resulting from intensified competition. Nowhere was this restructuring felt more intensely than in Dublin, with its older manufacturing plants. Between 1971 and 1981, employment in Dublin's traditional industries declined by 45\%. Expansionary budgets of the late 1970s to address economic difficulties generated rapid increases in inflation, with rates exceeding $20 \%$ for three consecutive years in the early $1980 \mathrm{~s}^{5}$. A crisis in the public finances forced cuts in public-sector spending and an embargo in public-sector recruitment, exacerbating the impacts of the general economic crisis. At a time when the city's population was increasing, employment in the services sector faltered. Unemployment in Dublin rose from 36,500 (1981) to 82,000 (1987). Simultaneous declines in industrial, office and residential development resulted in unemployment in the construction sector rising to over $45 \%$ by mid decade. By the end of the 1980 s, Dublin had become Ireland's problem region par excellence, the number unemployed exceeding the total of all the western seaboard counties, traditionally viewed as

3. Ibid., p. 85.

4. Ibid., p. 14.

5. MacLaran Andrew, Dublin: The Shaping of a Capital, London, Belhaven/ Wiley, 1993. 
qui produit la forme légale, et « la relation légale entre les individus consiste tout simplement en l'inversion de la relation entre les produits du travail, qui sont devenus des marchandises ${ }^{3} »$.

Cet argument a été approfondi par Arthur dans son introduction à l'édition de 1978 de l'ouvrage de Pashukanis:

Ce sont uniquement les conditions de la production marchande qui rendent nécessaire la forme légale abstraite - c'est uniquement dans ce contexte que l'on distingue un droit général, de revendications et de privilèges particuliers. C'est uniquement le transfert constant des droits de propriété dans le marché qui crée l'idée qu'il existerait un bénéficiaire fixe de ces droits. En réalité, la capacité de chacun à se penser comme bénéficiaires de droits de propriété empêche la pensée bourgeoise de concevoir les individus autrement que comme des sujets de droits; le fétichisme légal complète le fétichisme de marchandisation ${ }^{4}$.

\section{ÉLÉMENTS DE CONTEXTE}

Après l'entrée de l'Irlande dans la CEE en 1973, l'économie irlandaise a subi une restructuration en profondeur du fait de la compétition grandissante à laquelle elle était confrontée. Cette restructuration a été particulièrement forte à Dublin, vieille ville industrielle. Entre 1971 et 1981, l'emploi dans l'industrie traditionnelle y a chuté de $45 \%$. Le gonflement des budgets publics à la fin des années 1970, qui était destiné à faire face aux difficultés économiques, a rapidement fait bondir l'inflation qui a dépassé les $20 \%$ durant trois années consécutives au début des années $1980^{5}$. La crise des finances publiques a contraint à réduire les dépenses, à geler le recrutement dans la fonction publique, ce qui a accentué les effets plus globaux de la crise économique. Alors que la population de la ville augmentait, l'emploi dans le secteur des services a chuté. Le nombre de chômeurs à Dublin est passé de 36500 (en 1981) à 82000 (en 1987). Parallèlement, le déclin simultané de la construction de bâtiments industriels, de bureaux et de logements a engendré un chômage de plus de $45 \%$ dans le secteur du BTP au milieu des années 1980. À la fin de la décennie, Dublin est devenue, par excellence, la région à problème du pays, avec un nombre total de chômeurs supérieur à celui de toutes les régions du littoral occidental réunies, celles-là mêmes qui étaient jusqu'alors considérées comme les régions à problème de l'Irlande.

3. Ibid., p. 85.

4. Ibid., p. 14.

5. MacLaran Andrew, Dublin: The Shaping of a Capital, Londres, Belhaven/ Wiley, 1993. 
Ireland's problem regions. Unemployment rate in Dublin's inner city reached $35 \%$, with some social-housing areas recording rates over $80 \%{ }^{6}$. The physical environment reflected the depressed economic situation with 600 cleared sites and derelict buildings in the inner city in 1986, totalling 65 ha.

From the 1980s, the influence on the Irish government of neoliberal politics deepened, notably in urban regeneration. Such policies were underlain by a naïve ideology that markets were efficient distributors of resources and that market relationships should dictate social life. The state became more overtly orientated towards serving the interests of capital, changing the way in which the public sector operated, marking a movement towards laisser faire principles as market forces were given freer rein.

However, in Ireland, such trends were associated with a "social partnership" model of negotiated national wage bargaining rounds in which pay restraint was rewarded by improvements in public services and by reductions in taxation. Commencing with the Program for National Recovery in 1986, the "partnership" approach delivered a quiescent labour force in return for rising real incomes, the implementation of a series of such agreements over two decades created effective control over wages and salaries. In contrast, the agreements ignored incomes from investments, property or shareholding dividends. They deflected attention from rising levels of business profitability and incomes from self-employment. Indeed, tax rates were reduced to just $12.5 \%$ on business profits and from $40 \%$ to $20 \%$ on capital gains. As a result, the share in the economy taken as wages and salaries declined from $73 \%$ in 1987 to $58 \%$ in 1999 , the lowest rate within the European Union.

As in the United Kingdom, neoliberalism infected the regime of urban development planning. From the mid 1980s, deepening entrepreneurialism in Irish urban governance saw urban planning working together with property development interests to effect planning goals ${ }^{7}$. This was achieved by ensuring that plans conformed to developers' profitability criteria,

6. Ibid.

7. McGuirk Pauline, MacLaran Andrew, "Changing approaches to urban planning in an 'entrepreneurial city': the case of Dublin", in European Planning Studies, 9 (4), 2001, p. 437-457. 
Le chômage a atteint 35 \% dans le centre-ville de Dublin, avec des records de l'ordre de $80 \%$ et plus dans certains quartiers populaires où domine le logement social ${ }^{6}$. La crise économique s'est reflétée dans la dégradation de l'environnement urbain: il y avait 600 secteurs en friche et immeubles en ruines dans le centre-ville en 1986, occupant au total 65 hectares.

À partir des années 1980, l'influence des politiques néo-libérales sur le gouvernement irlandais s'est accentuée, notamment en matière de régénération urbaine. Ces politiques se fondaient sur une idéologie naïve qui voyait dans le marché un outil efficace de redistribution des richesses, et selon laquelle les relations dictées par le marché doivent s'imposer à la vie sociale. L'État s'est mis plus ouvertement au service des intérêts du capital, modifiant les modes d'intervention du secteur public, s'engageant dans la voie du laisser faire et relâchant la bride aux forces du marché.

Néanmoins, en Irlande, ces évolutions se sont accompagnées d'un modèle de "partenariat social» fondé sur un cycle de négociations salariales au niveau national, au cours desquelles le gel des salaires a été compensé par une amélioration des services publics et des allègements d'impôts et de taxes. Lancé en 1986 avec le Programme pour le Rétablissement National, ce "partenariat» a acheté la passivité de la main-d'œuvre en échange d'une augmentation des revenus réels; durant deux décennies, l'application d'une série d'accords de ce type a permis de garder les rémunérations et les salaires sous contrôle. En revanche, ces accords ont occulté totalement les revenus tirés de l'investissement, de l'immobilier et de l'actionnariat. Ils ont fait oublier que pendant ce temps les profits des entreprises augmentaient, ainsi que les revenus liés à l'emploi non salarié. En effet, la taxation des profits des entreprises a été ramenée à $12,5 \%$ et celle sur les revenus du capital est passée de $40 \%$ à $20 \%$. Par conséquent la part des salaires et du travail rémunéré dans l'économie a chuté de $73 \%$ en 1987 à $58 \%$ en 1999, le taux le plus bas de toute l'Union européenne.

Comme au Royaume-Uni, le néo-libéralisme a contaminé la planification et le développement urbains. À partir du milieu des années 1980, l'influence accrue de l'idéologie entrepreneuriale sur la gouvernance urbaine s'est fait sentir en Irlande, avec le rapprochement entre le travail des planificateurs et les intérêts des promoteurs immobiliers ${ }^{7}$. Concrètement, les plans d'urbanisation devaient se conformer aux critères de rentabilité des

6. Ibid.

7. McGuirk Pauline, Maclaran Andrew, "Changing approaches to urban planning in an "entrepreneurial city": the case of Dublin ", in European Planning Studies, $n^{\circ} 9$ (4), 2001, p. 437-457. 
permitting increased development densities ${ }^{8}$, by "pump-priming" of private investment through public-sector expenditure on necessary infrastructures, by subsidising development costs through tax incentives and by facilitating private-sector site assembly by obliging local authorities to dispose of their inner-city land holdings to private developers. Meanwhile, the effective influence of the general public over urban planning was reduced through the "fast tracking" of development planning with the establishment of special-purpose agencies and by the increasing use of joint ventures between the state and private capital ${ }^{9}$. Local government roles were sometimes by-passed altogether, key functions being vested in alternative, often centralised or quasi-private agencies such as the Custom House Dock Development Authority.

Strategic alliances were forged between urban planning, the economic boosterism lobby and the property-development sector to reinvent the image (and reality) of the city, to make it "liveable" and more attractive to the middle class, to create an urban landscape which would be iconographic of economic success, growth and change.

From 1986, key inner-city areas were designated as qualifying for fiscal incentives for property-related renewal. The measures provided a signal for capital to return to run-down inner-city areas, effecting a massive revalorisation of land. The initial impact was a wave of office development in areas fringing the traditional office core, swiftly followed by apartment construction for owner occupation or sale to landlords ${ }^{10}$.

8. The permitted development density for inner-city apartments had traditionally been 115 dwellings per ha. This have recently increased to over 240 per ha, some applications having densities greater than 500 per ha.

9. Maclaran Andrew, Clayton Vanda, Brudell Paula, Empowering Communities in Disadvantaged Urban Areas: Towards Greater Community Participation in Irish Urban Planning?, Dublin, Combat Poverty Agency, 2007; MacLaran Andrew, Clayton Vanda, Brudell Paula, "Empowering Communities in Disadvantaged Urban Areas: Towards Greater Community Participation in Irish Urban Planning? A Research Summary", in Journal of Irish Urban Studies, vol. 4-6, 2007, p. 73-88.

10. Kelly Sinéad, MacLaran Andrew, "The Residential Transformation of Inner Dublin", in Dublin: Economic and Social Trends, Volume 4, Drudy P. J., MacLaran Andrew (dir.), Dublin, Centre for Urban and Regional Studies, Trinity College Dublin, 2004, p. 36-59. 
promoteurs immobiliers : ils visaient à leur permettre d'augmenter les densités $^{8}$, à amorcer la pompe de l'investissement privé en assurant que les dépenses publiques seraient dirigées vers les bonnes infrastructures, à subventionner indirectement les programmes immobiliers grâce à des incitations fiscales et à faciliter les opérations immobilières du secteur privé en obligeant les pouvoirs locaux à mettre à leur disposition leurs réserves foncières du centre-ville. Parallèlement, la capacité qu'avait la société civile à influencer réellement la planification urbaine a été réduite par la mise en place de procédures d'urbanisme spéciales et accélérées (on parle de "fast tracking »), la création d'agences spécialisées et le recours accru à des jointventures entre l'État et le capital privé'. Les gouvernements locaux ont parfois été purement et simplement court-circuités, certaines de leurs missions étant transférées à des agences souvent centralisées, voire quasiment privées, comme le Custom House Dock Development Authority.

Des alliances stratégiques furent forgées entre les planificateurs, le lobby favorable à la croissance économique et le secteur immobilier, destinées à réinventer l'image (et la réalité) de la ville, de manière à la rendre « vivable » et plus attractive pour la classe moyenne, et à créer un paysage urbain et une iconographie urbaine emblématiques du succès économique, de la croissance et du changement.

À partir de 1986, on a sélectionné en centre-ville des secteurs clés devant bénéficier de mesures d'incitation fiscale et du renouvellement urbain. Ces mesures constituèrent un signal fort destiné à encourager le retour du capital vers les zones en souffrance du centre-ville afin de revaloriser le foncier. Une première vague de construction de bureaux aux marges du cœur traditionnel du quartier d'affaires fut rapidement suivie d'une vague de construction d'immeubles d'habitation destinés à des propriétaires occupants ou à des propriétaires bailleurs ${ }^{10}$.

8. La densité de construction autorisée pour les immeubles d'habitation au centre-ville a été historiquement fixée à 115 logements par hectare. Ce seuil a été récemment porté à plus de 240 logements par hectare, certains programmes attestant de densités supérieures à 500 logements par hectare.

9. Maclaran Andrew, Clayton Vanda, Brudell Paula, Empowering Communities in Disadvantaged Urban Areas: Towards Greater Community Participation in Irish Urban Planning?, Dublin, Combat Poverty Agency, 2007; MacLaran Andrew, Clayton Vanda, Brudell Paula, "Empowering Communities in Disadvantaged Urban Areas: Towards Greater Community Participation in Irish Urban Planning? A Research Summary ", in Journal of Irish Urban Studies, vol. 4-6, 2007, p. 73-88.

10. Kelly Sinéad et MacLaran Andrew, "The Residential Transformation of Inner Dublin ", in Dublin: Economic and Social Trends, Volume 4, Drudy P. J., 
The economic boom of the 1990s had a major impact on the city. Real Gross Domestic Product (GDP) grew at over 3\% per annum during the 1990s and the per capita level surpassed that of the UK by the end of the decade. Demand for land for building was strong, notably for offices to accommodate the expanding services sector and for residential units to house a growing workforce, many of whom were expressing a preference for an inner-city lifestyle. The impacts on land price were especially strong in the inner city ${ }^{11}$.

Through the 1990s, neoliberalism was warmly embraced by Irish governments. Policy became infused with a vocabulary drawn from the business world: "mission statements", "cost centres", "stakeholders", "benchmarking" and "performance indicators" etc. It was accompanied by a growing managerial ethos of control and neo-authoritarianism and associated with the privatisation of semi-state bodies and key public-sector operations (e.g. Irish Life and Irish Telecom) and the "out-sourcing" of some public services. It also involved an increasing use of Public-Private Partnerships (PPPs), where private capital is engaged directly in partnership with the state under a variety of arrangements ${ }^{12}$ to provide infrastructure (e.g. toll roads, school buildings) and services (e.g. light rail operations) which would traditionally have been undertaken by the state directly or by its agencies. Though originating with the central state, PPPs became forcibly implanted into the local-authority sector, notably in large-scale renewal of social housing. From small origins, these are destined to become of major significance, the national Budget of 2004 setting targets for PPPs to increase from 3\% of public-sector capital investment in 2004 to 15\% in 2008.

11. Ibid.

12. The arrangements can include any or all of the following: designing, building/developing, financing and operating infrastructure or services (see HeArNe Rory, "Public-Private Partnerships in Irish Schools", in Journal of Irish Urban Studies, vol. 4-6, 2007, p. 55-72). 
Le boom économique des années 1990 eut un impact majeur sur la ville. Le PIB réel augmenta de plus de $3 \%$ par an durant les années 1990 et le revenu par tête dépassa celui du Royaume-Uni à la fin de la décennie. La demande de terrains à bâtir en ville était considérable, en particulier pour les bureaux qui devaient accueillir les activités de services en plein essor, et pour les logements destinés à accueillir une nouvelle main-d'œuvre, elle aussi en pleine croissance, et qui souhaitait massivement vivre en centreville. L'impact de ces dynamiques sur le coût du foncier fut particulièrement marqué au centre-ville ${ }^{11}$.

Durant la décennie 1990, les gouvernements successifs en Irlande ont embrassé avec ardeur le néo-libéralisme. Un vocabulaire venu du monde des affaires s'est diffusé en politique: "mission statements ", «cost centres", "stakeholders", "benchmarking» et "performance indicators ${ }^{12}$ », etc. Cela s'est accompagné de l'essor d'une éthique managériale fondée sur un désir de contrôle néo-autoritaire, de la privatisation d'organismes parapublics et d'opérateurs publics majeurs (par exemple Irish Life et Irish Telecom), mais aussi de l'externalisation d'une partie des services publics. Cette évolution s'est traduite également par un recours accru aux partenariats public-privé (PPP), dans lesquels l'engagement du capital privé aux côtés du secteur public s'effectue sous des formes de coopération variées ${ }^{13}$, que ce soit pour réaliser des infrastructures (par exemple des routes à péages, des bâtiments scolaires) ou fournir des services (par exemple le tramway) qui auraient traditionnellement été pris en charge directement par l'État ou par des agences publiques. Bien qu'il ait d'abord été diffusé à l'échelle nationale par l'État central, le principe du PPP s'est imposé aux pouvoirs locaux, en particulier dans les opérations de rénovation à grande échelle de l'habitat social. Après des débuts modestes, les PPP prirent une ampleur considérable; en 2004, les objectifs inscrits au budget de l'État étaient de faire passer les PPP de $3 \%$ des investissements publics cette année-là à $15 \%$ en 2008 .

Maclaran Andrew (dir), Dublin, Centre for Urban and Regional Studies, Trinity College Dublin, 2004, p. 36-59.

11. Ibid.

12. Ce vocabulaire venu du monde anglophone est difficile à traduire en français et il est parfois passé directement dans l'usage courant des urbanistes et aménageurs. On pourrait cependant le traduire par les termes: "objectifs ", " centres de coûts ", " acteurs responsables ", " évaluation» et " indicateurs de performance » [NDT].

13. La coopération peut porter sur l'un des domaines suivants ou sur tous ces domaines à la fois: la conception, la construction/promotion, le financement et la gestion des infrastructures ou des services (voir Hearne Rory, « Public-Private Partnerships in Irish Schools ", in Journal of Irish Urban Studies, vol. 4-6, 2007, p. 55-72). 


\section{Integrated Area Plans}

The impacts of the early urban renewal incentives were subjected to widespread criticism, notably for their property-related emphasis and for ignoring community concerns. The shortcomings were largely accepted by the government's appointed consultant reviewers ${ }^{13}$. From the late 1990s, area-based urban regeneration would be grounded in Integrated Area Plans (IAPs), balancing subsidies to property capital by prospects of community participation and community gain. The approach is described by Gleeson ${ }^{14}$ as incorporating

a more holistic planning philosophy, with the social and economic agenda balancing the more traditional emphasis on environmental aspects. Emphasising consultation, the IAP can respond with focused strategies to address local issues on the ground.

In theory, IAPS were to operate as localised planning mechanisms aiming to achieve social, economic and environmental goals, translating broad planning aims into locally-focused implementation strategies, providing for the integration of public, private and community sectors to create a collaborative effort towards holistic regeneration.

The IAP approach became the key element in the Government's Urban Renewal Schem $\mathrm{e}^{15}$. The approach offered the prospect of community participation in regeneration through local IAP Steering Committees. However, by failing to establish satisfactory terms of reference and by creating only ex post facto Monitoring Committees to approve what had already taken place, community participation was drastically diminished.

13. KPMG, Murray O'Laoire Associates and Northern Ireland Economic Research Centre, Study on the Urban Renewal Schemes, Dublin. Dublin, Department of the Environment, 1996.

14. GLEESON Dick, "Changing approaches to planning in Dublin's inner city", in Dublin: Contemporary Trends and Issues for the Twenty-First Century, Killen James, MacLaran Andrew (dir.), Dublin, Geographical Society of Ireland, Special Publication 11, 1999, p. 49-55.

15. Department of the Environment and Local Government, Urban Renewal Scheme: Monitoring Guidelines, Dublin, Stationery Office, 1999. 


\section{Plans D’urbanisme locaux INTÉGrés (IAP)}

Les conséquences des premières mesures d'incitation au renouvellement urbain ont été abondamment critiquées, en particulier pour leurs effets en matière d'immobilier et pour avoir ignoré les préoccupations des communautés concernées. Ces défauts ont été largement admis par les consultants nommés par le gouvernement ${ }^{14}$. À partir de la fin des années 1990, les plans locaux de renouvellement urbain durent s'appuyer sur des Plans Locaux Intégrés (IAP ${ }^{15}$ ) qui cherchaient à instaurer un équilibre entre subventions au capital immobilier d'une part et perspectives de participation et de gain pour les communautés d'autre part. Pour Gleeson, cette approche est fondée sur:

une philosophie de la planification plus holistique, le projet social et économique contrebalançant le volet urbanistique plus classique. Parce qu'ils mettent l'accent sur la consultation, les IAP peuvent, à l'aide de stratégies bien ciblées, traiter des problèmes locaux, concrètement sur le terrain ${ }^{16}$.

En théorie, les IAP étaient conçus comme des outils locaux de planification urbaine englobant des objectifs économiques, sociaux et urbanistiques et permettant de traduire localement des principes plus généraux de planification via des stratégies de mise en ouvre centrées sur l'échelle locale et intégrant acteurs publics, privés et communautaires dans un souci de collaboration, en vue d'un renouvellement urbain global et intégré.

Les IAP sont devenus le pivot du Programme Gouvernemental de Renouvellement Urbain ${ }^{17}$. Cette approche a ouvert des perspectives en matière de participation communautaire au renouvellement urbain par la création de comités locaux de pilotage de l'IAP. Cependant, la participation communautaire a été considérablement limitée parce que les conditions et les termes de la participation n'ont pas été définis de manière satisfaisante et parce que les comités directeurs ont seulement été créés a posteriori, pour valider des décisions en fait déjà prises.

14. KPMG, Murray O'Laoire Associates and Northern Ireland Economic Research Centre, Study on the Urban Renewal Schemes, Dublin, Dublin, Department of the Environment, 1996.

15. Integrated Area Plans.

16. GLeEson Dick, "Changing approaches to planning in Dublin's inner city », in Dublin: Contemporary Trends and Issues for the Twenty-First Century, Killen James, MacLaran Andrew (dir.), Dublin, Geographical Society of Ireland, Special Publication 11, 1999, p. 49-55.

17. Department of the Environment and Local Government, Urban Renewal Scheme: Monitoring Guidelines, Dublin, Stationery Office, 1999. 
Furthermore, by providing misinformation, failing to allocate adequate resources to community representatives and, sometimes, by marginalizing and discrediting them, participation became tokenistic and highly cyni$\mathrm{cal}^{16}$. Moreover, the delivery of very little community gain under IAPs ${ }^{17}$, compared to the scale of tax incentives given to property developers and investors, resulted in inner-city working-class communities increasingly viewing IAPs as agents of the property development sector, effecting the incorporation of working-class protest ${ }^{18}$.

\section{IAPs: Facilitating Development, Silencing the Marginalised}

In recognition of the way in which debates about the efficacy of entrepreneurial polices have been "dominated by the hollow rhetoric of politicians and policy makers," Hall and Hubbard ${ }^{19}$ have pointed to the need to explore "the manner in which entrepreneurial cities are experienced and understood by local populations, and the ways in which this differs from the hyperbole of the city boosters" and "élite coalitions" espousing such policies $^{20 "}$.

This section explores the experience of one inner-city community in its attempt to engage with the local state in the implementation of one of the IAPs in the context of increasing levels of property development activity in the locality (see Figure 1). Located at the south-western edge of Dublin's central business area, the Liberties comprises an old and distinctive quarter which once accommodated a vibrant working-class community finding employment in a variety of local labour-intensive industries.

16. Brudell Paula, Hammond Charlie, Henry Josephine, "Urban planning and regeneration: a community perspective", in Journal of Irish Urban Studies, 3 (1), 2004, p. 65-87.

17. By 2004 , only 487,000 euros in community gain had accrued through the Liberties IAP, which represents the price of a 2two-bedroomed apartment in the area. Upon completion, it is estimated that community gain may total 6.38 million euros. In contrast, tax benefits to developers and investors will exceed 70 million euros.

18. Brudell Paula, Hammond Charlie, Henry Josephine, "Urban planning and regeneration: a community perspective", op. cit.

19. The Entrepreneurial City: Geographies of Politics, Regime and Representation, Hall Tim, Hubbard Phil (dir.), Chichester, Wiley, 1998, p. 18.

20. Ibid., p. 21. 
En outre, à force de désinformation, à force de ne pas allouer les ressources nécessaires aux représentants des communautés, à force parfois de les marginaliser et de les discréditer, la participation s'est changée en un pur exercice de forme et de cynisme ${ }^{18}$. De plus, la maigreur des gains engendrés par les $\mathrm{IAP}^{19}$ pour les habitants des quartiers centraux, comparée à l'ampleur des avantages fiscaux accordés aux promoteurs et aux investisseurs, poussa les populations ouvrières à ne voir dans les IAP que des outils au service des promoteurs, chargés d'absorber leurs protestation ${ }^{20}$.

\section{Les IAP: faciliter le développement immobilier, faire taire les exclus}

Constatant que les débats sur l'efficacité des politiques entrepreneuriales ont été « dominés par la rhétorique creuse des politiciens et des concepteurs de ces politiques ${ }^{21} »$, Hall et Hubbard ont souligné la nécessité d'étudier «la façon dont les populations locales font l'expérience des villes entrepreneuriales dans leur quotidien, la manière dont elles les comprennent, à mille lieues de l'hyperbole des « city boosters ${ }^{22}$ » et autres « coalitions d'élites locales » qui adoptent ces politiques ${ }^{23} »$.

Dans cette partie, nous étudions les tentatives d'une communauté du centre-ville de Dublin pour participer activement, en collaboration avec le gouvernement local, à la mise en œuvre d'un IAP (voir Figure 1). Situé au sud-ouest du quartier d'affaires de Dublin, les Liberties comprennent un vieux quartier ouvrier très typé, autrefois très animé, dont la population était employée dans différentes entreprises industrielles locales à forte densité de main-d'œuvre.

18. Brudell Paula, Hammond Charlie, Henry Josephine, « Urban planning and regeneration: a community perspective ", in Journal of Irish Urban Studies, $\mathrm{n}^{\circ} 3$ (1), 2004, p. 65-87.

19. En 2004, l'IAP du quartier des Liberties n'a rapporté que 487000 euros aux communautés locales, soit le prix d'un appartement de trois pièces dans le quartier. Une fois achevé, on estime qu'il devrait rapporter au total 3,5 millions d'euros aux communautés locales. En comparaison, les incitations fiscales à destination des promoteurs et des investisseurs dépasseront 70 millions d'euros.

20. Brudell Paula, Hammond Charlie, Henry Josephine, « Urban planning and regeneration: a community perspective », op. cit.

21. The Entrepreneurial City: Geographies of Politics, Regime and Representation, Hall Tim, Hubbard Phil (dir.), Chichester, Wiley, 1998, p. 18.

22. L'expression City Boosters désigne les acteurs urbains qui considèrent que la « redynamisation » de la ville passe par la mise en place d'une nouvelle forme de gouvernance privilégiant les partenariats public/privé [NDT].

23. Ibid., p. 21. 


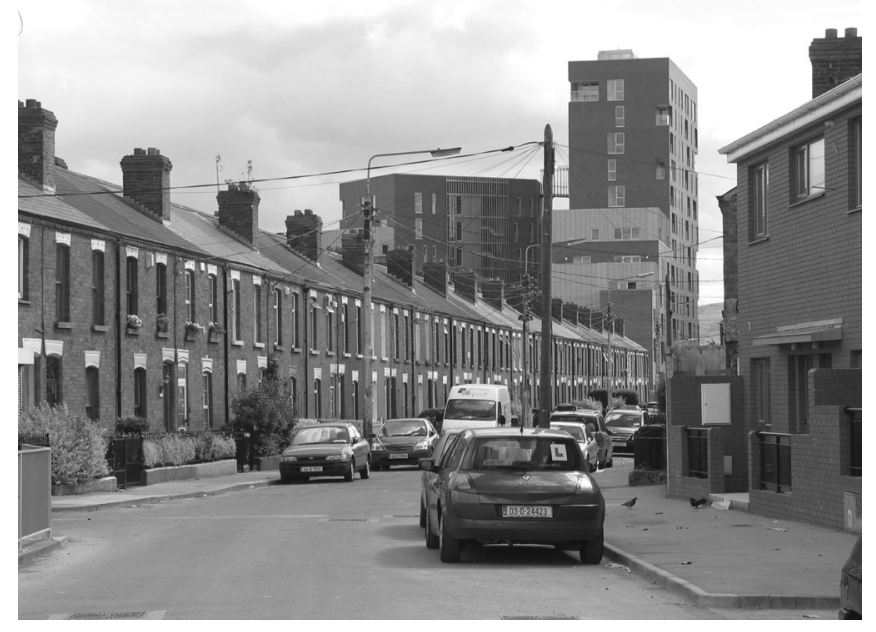

Fig. 1. Increasing scale of development in the Liberties

As economic circumstances changed mid-century, marked by the closure of virtually all its traditional industries and economically devastating the area, the labour force became surplus to capital's requirement ${ }^{21}$. The withdrawal of industrial capital was compounded by a long period of government inaction, allowing the area to descend into a state of dangerous physical dereliction. A series of inter-agency and partnership-type structures attempted to address the community's socio-economic plight. However, the late 1990s saw the appearance of a party with an altogether different interest in the area. Increasingly, property capital recognised the potential profit to be wrung from the area's close proximity to the city centre and that the area's most valuable asset was no longer its labour power but its land. In realising this potential, it was to be greatly assisted by the state's urban renewal policies.

Hailed as "a radical departure from previous schemes ${ }^{22}$ ", IAPs were to address" 23 "not only issues of physical development but also cover wider

21. KelLy Sinéad, “The Liberties transformed: The Emergence of New Commercial and residential spaces in inner Dublin", in Journal of Irish Urban Studies, vol. 4-6, 2007, p. 89-118.

22. Department of the Environment and Local Government, Urban Renewal Scheme: Monitoring Guidelines, op. cit.

23. Dublin Corporation changed its title to Dublin City Council in late 2001. 
Quand le contexte économique changea, au tournant du siècle, avec la fermeture de quasiment toutes les industries traditionnelles et le désastre économique qui s'ensuivit dans le quartier, la force de travail devint surnuméraire par rapport aux besoins du capita ${ }^{24}$. La désindustrialisation fut aggravée par une longue période d'attentisme gouvernemental qui conduisit à une dégradation physique extrême du quartier. Des montages successifs, fondés sur la coopération entre des agences ou différentes sortes de partenariats, furent tentés pour faire face à la crise économique et sociale que connaissait cette communauté. Cependant, à la fin des années 1990, surgit un nouvel acteur ayant un intérêt tout différent pour ce quartier. Le capital immobilier commença à percevoir de plus en plus clairement le profit qu'il pouvait tirer d'un quartier si proche du centre-ville et dont le principal atout n'était plus sa force de travail, mais ses terrains. Il fut largement accompagné dans cette prise de conscience par les politiques publiques de renouvellement urbain.

Salués comme « une rupture majeure par rapport aux précédents programmes ${ }^{25}$ ", les IAP devaient s'attaquer "non seulement aux questions d'environnement urbain dans leur dimension matérielle, mais aussi à des enjeux socio-économiques plus larges ${ }^{26} »$. On les présenta comme des outils permettant de "provoquer un renouvellement urbain durable en intégrant interventions physiques, sociales et économiques afin de prendre en charge les problèmes spécifiques à un quartier ${ }^{27} »$. Outre le détail des objectifs de rénovation urbaine des cent sites retenus au titre des exemptions fiscales, l'IAP des Liberties comportait de nombreux objectifs socioéconomiques que les communautés considéraient comme prioritaires.

24. Kelly Sinéad, "The Liberties transformed: The Emergence of New Commercial and residential spaces in inner Dublin ", in Journal of Irish Urban Studies, vol. 4-6, 2007, p. 89-118.

25. Department of the Environment and Local Government, Urban Renewal Scheme: Monitoring Guidelines, op. cit.

26. Dublin Corporation, «Integrated Area Plans: Urban Renewal Tax Incentive Scheme », fascicules, 1999.

27. Dublin Corporation, Liberties/Coombe Integrated Area Plan, Dublin, Dublin Corporation, 1998. 
issues of local socio-economic benefit ${ }^{24}$. These were heralded as bringing "about sustainable urban regeneration by integrating physical, social and economic interventions to address the key issues in the area ${ }^{25}$ ". In addition to detailing the physical-renewal objectives for each of the 100 tax-designated sites, the Liberties IAP also articulated many socio-economic objectives high on the community's agenda.

Having convinced the community of the benefits to be derived from the IAP, Dublin City Council (DCC) persuaded it to set aside its traditional adversarial relations with the local authority and engage with the IAP by helping to oversee its implementation. In practical terms, this translated into four community organisations each formally delegating a representative to the IAP's Monitoring Committee. However, this represented a downgrading in functions compared to the promise to establish a crosssectional Steering Group to which a "Project Implementation Team" would be responsible and to which it would report ${ }^{26}$.

From the outset, the community's representatives encountered difficulties in engaging with the local state. It refused to provide terms of reference governing their role and function or the resources necessary to participate effectively. In an environment in which information was often imparted after the event (if at all), the community representatives were relegated to the position of unequal and uninformed participants. As they became aware of their diminishing role in the IAP, they made several attempts to engage DCC over their concern $s^{27}$. However, officials never conceded the validity of those issues.

Meanwhile, those concerns became increasingly acute as planning issues on individual tax-designated sites came to the fore. As developers began submitting planning applications for developments of a scale well in excess of the building heights and densities provided for in the IAP, the commu-

24. Dublin Corporation, "Integrated Area Plans: Urban Renewal Tax Incentive Scheme”, fascicules, 1999.

25. Dublin Corporation, Liberties/Coombe Integrated Area Plan. Dublin, Dublin Corporation, 1998.

26. Dublin Corporation, "Integrated Area Plans: Urban Renewal Tax Incentive Scheme", op. cit.; Brudell Paula, Hammond Charlie and Henry Josephine, "Urban planning and regeneration: a community perspective", op. cit.

27. Brudell Paula, A Mandate for the Community Representatives to the Liberties/ Coombe Integrated Area Plan; A Report from the Seminar on Community Gain, Dublin, South West Inner City Network, 2000; Brudell Paula, Minority Report of the Community Representatives to the Liberties/Coombe Integrated Area Plan, Dublin, South West Inner City Network, 2002. 
Ayant convaincu la communauté des bienfaits qui devaient découler de cet IAP, la Ville de Dublin $\left(\right.$ DCC $\left.^{28}\right)$ la persuada de mettre de côté sa tradition d'antagonisme avec le pouvoir local et de prendre part à l'IAP en aidant à superviser sa mise en œuvre. En pratique, cela se traduisit par l'implication de quatre organisations communautaires, chacune déléguant officiellement un représentant auprès du comité de direction du IAP. Il s'agissait déjà d'un recul par rapport aux promesses d'établir un comité de pilotage croisé auquel une « équipe de mise en œuvre du projet » rendrait des comptes ${ }^{29}$.

Dès le départ, les représentants de la population rencontrèrent des difficultés dans leur tentative de dialogue avec les pouvoirs locaux. Ces derniers refusèrent de définir les conditions et les termes de la participation communautaire et de leur fournir les moyens matériels pour participer réellement au processus de décision. Dans un contexte où l'information était le plus souvent délivrée après coup (ou bien pas du tout), les représentants communautaires furent confinés au rôle de participants mal informés et ne furent pas traités en égaux. Quand ils prirent conscience que leur rôle au sein de l'IAP allait s'amenuisant, ils tentèrent à plusieurs reprises de faire part de leur préoccupation au Conseil Municipal de Dublin (DCC) ${ }^{30}$. Mais les représentants de la Ville ne reconnurent jamais la validité de leurs requêtes.

Cependant, ces requêtes se firent de plus en plus vives au fur et à mesure que les questions de planification liées aux zones franches prenaient de l'importance. Comme les promoteurs déposaient des demandes de permis de construire pour des projets dépassant largement les réglementations, en termes de hauteur ou de densités contenues dans le IAP, les habitants s'attendaient à ce que ces demandes soient automatiquement rejetées. Au lieu de cela, le DCC se mit à délivrer une série de permis de construire qui contrevenaient à ses propres règlements urbanistiques et à son propre IAP.

28. Le Dublin City Council (ou DCC) est la Ville de Dublin [NDT].

29. Dublin Corporation, «Integrated Area Plans: Urban Renewal Tax Incentive Scheme ", op. cit.; Brudell Paula, Hammond Charlie, Henry Josephine, "Urban planning and regeneration: a community perspective ", op. cit.

30. Brudell Paula, A Mandate for the Community Representatives to the Liberties/ Coombe Integrated Area Plan; A Report from the Seminar on Community Gain, Dublin, South West Inner City Network, 2000; Brudell, Paula, Minority Report of the Community Representatives to the Liberties/Coombe Integrated Area Plan, Dublin, South West Inner City Network, 2002. 
nity awaited their automatic refusal. Instead, DCC proceeded to grant a series of planning permissions, which breached its own design specifications and contravened its own IAP.

After a cursory engagement with the community over the precise standing of the IAP and the hierarchy of other plans and government "guidelines" used in determining planning applications, DCC responded that it saw "no merit in engaging in further correspondence" on the issue ${ }^{28}$. When community representatives persisted with their objections, they were told that "things had changed", that "the detail of the IAP had been superseded by new residential density guidelines from the Department of the Environment", a fact which had never been communicated to the Monitoring Committee! Officials retorted that if they were unhappy with planning decisions, they were free, as private citizens under the normal provisions for third-party objections, to appeal decisions to An Bord Pleanála ${ }^{29}$.

Subsequent attempts to engage the central government over the implementation of the IAP proved equally futile. The community representatives were told that their non-approval of the local authority's annual report to the Department of the Environment held "no implications". Attempts to secure a response to a highly critical Minority Report submitted directly to the Minister resulted in the community's being informed that IAPs were "in law, matters within the competence of the local authority ${ }^{30 "}$ and that the Minister would not be engaging further.

Thus, the community was obliged to confront its true function on the IAP Monitoring Committee. The community representatives were divided. Two continued their participation. Two formally resigned, refusing to allow DCC any further opportunity to make them complicit in the way in which the state was implementing and contravening the IAP. One community representative appealed successive cases to An Bord Pleanála. A pattern became established where intense pressure from property-development interests and politicians was exerted on him to withdraw his appeals. As it transpired, there was little cause for their concern as An Bord Pleanála repeatedly upheld planning decisions in contravention of the IAP.

28. Cited in Brudell Paula, Minority Report of the Community Representatives..., op. cit.

29. The planning appeals board.

30. DAIL Eireann, "Written response to parliamentary question re Integrated Area Plans", 23 October 2002, Accessed 03 Aug 2006, (http://www.irlgov.ie/debates02/23Oct/Sect10.htm). 
Après un débat superficiel avec la communauté sur les normes exactes de l'IAP et pour savoir quels documents de planification et quels règlements publics s'imposaient aux autres en matière urbanistique, le DCC fit savoir qu'il «ne voyait pas l'intérêt de poursuivre cette correspondance ${ }^{31}$ » et de débattre de ces questions. Quand les représentants de la communauté voulurent malgré tout objecter, on leur répondit que «les choses avaient changé », que « le contenu détaillé de l'IAP avait été remplacé par de nouvelles normes réglementaires en matière de densité, émanant du ministère de l'Environnement ", élément dont le comité de direction n'avait pas été tenu informé! Les fonctionnaires municipaux répliquèrent que quiconque était insatisfait des décisions en matière de planification pouvait, en tant que citoyen et à titre privé et individuel, s'en remettre aux procédures de recours classiques et faire appel au Bureau d'Appel pour la Planification ${ }^{32}$.

Les démarches entreprises auprès du gouvernement central pour discuter de la mise en œuvre de l'IAP furent tout aussi vaines. Les représentants communautaires s'entendirent répondre que leur refus d'approuver le rapport annuel soumis par la Ville au ministère de l'Environnement n'avait aucune incidence. Leurs efforts pour obtenir une réponse à un Minority Report très critique, qu'ils avaient directement soumis au ministère se solda par un échec: la communauté fut informée que l'IAP relevait « légalement de la compétence des pouvoirs locaux ${ }^{33}$ » et que le ministère ne poursuivrait pas cet échange.

La communauté fut alors contrainte de prendre acte de ce qu'étaient réellement ses fonctions au sein du comité de direction de l'IAP. Ses représentants furent divisés. Deux d'entre eux souhaitèrent continuer à participer à ce comité. Deux autres se retirèrent, refusant de donner plus longtemps au DCC la possibilité de les rendre complices de la manière dont l'IAP était mis en œuvre par les pouvoirs publics et ainsi perverti. Un représentant choisit de faire appel, et ce à plusieurs reprises, au An Bord Pleanála. Il fut contraint de retirer ses plaintes sous la pression conjuguée des promoteurs immobiliers et de politiciens. Il semble pourtant que leurs craintes aient été peu fondées car le An Bord Pleanála confirma à plusieurs reprises des décisions urbanistiques pourtant non conformes à l'IAP.

31. Cité in Brudell Paula, Minority Report of the Community Representatives..., op. cit.

32. An Bord Pleanála [NDT].

33. DAIL Eireann, «Written response to parliamentary question re Integrated Area Plans », 23 octobre 2002. 
The experience led to a radicalisation of political perspectives among many who had sought, in good faith, to engage constructively in the participation process. Some became severe critics of the renewal plan for facilitating the redevelopment of this once-distinctive quarter of Dublin's inner city in a manner entirely contrary to that outlined in the IAP, having become a renewal plan which again effectively focused on physical renewal ${ }^{31}$.

When individual community representatives sought intervention from the European Commission, which authorised the use of tax incentives in the IAPs, they were met with equal silence. The much-heralded "community perspective" had become a wholly unwelcome voice of critical dissent.

Those who continue to dissent from the hyperbole of the city boosters are left to compare the rhetoric in which the state couched its initial invitation to participate, with the manner in which they were treated when they refused to agree uncritically with the planning contraventions and socioeconomic failures of the plan. They contend that the Irish state misrepresented the real agenda of the IAPs and the role and standing of the community representatives; that the inclusion of the community within the IAP structures was merely an attempt to pre-empt and co-opt any opposition among a largely property-less working-class to the private-sector development agenda being pursed via the IAPs; and that the state's newly-found modus operandi of conciliatory partnership functions to preclude and negate the emergence of any legitimate criticism of what is being done to working-class communities in the name of urban renewal, which is heralded as an entirely positive, progressive and positive process.

\section{Land Price, the Neoliberal Agenda and Social Housing}

By 2005, more than a decade of economic boom and a declining number of available inner-city development sites resulted in significant increases inland prices, the cheapest inner-city sites selling at 24 million euros per hectare and those in prestigious Ballsbridge reputed to have sold for over

31. Brudell Paula, Hammond Charlie, Henry Josephine, "Urban planning and regeneration: a community perspective", op. cit.; Kelly Sinéad, MacLaran Andrew, "The Residential Transformation of Inner Dublin", op. cit.; Department of Finance, Goodbody Review of Area-Based Tax Incentive Renewal Schemes, Dublin, Government of Ireland, 2006. 
Cette expérience radicalisa politiquement beaucoup de ceux qui avaient tenté, en toute bonne foi, de s'engager dans un processus de participation constructif. Certains critiquèrent sévèrement un plan de renouvellement urbain qui visait à transformer ce quartier autrefois très typique du centre de Dublin, et ce en contradiction totale avec le contenu de l'IAP, en mettant à nouveau uniquement l'accent sur la mutation paysagère et la transformation de l'environnement physique ${ }^{34}$.

Lorsque des représentants communautaires saisirent à titre individuel la Commission européenne, qui autorisait le recours à des incitations fiscales dans les IAP, ils se heurtèrent au même mur de silence. La belle « perspective communautaire ", un temps très sollicitée et mise en avant, s'était muée en parole critique et dissidente, jugée largement malvenue.

Ceux qui continuent d'exprimer leur désaccord avec les City Boosters n'ont plus désormais qu'à comparer la rhétorique des débuts (lorsque l'État invitait les habitants à participer au processus) à la manière dont ils ont été traités quand ils ont refusé d'acquiescer benoîtement aux irrégularités en matière de planification et aux échecs socio-économiques de ce plan. Ils estiment que l'État irlandais a dénaturé le projet originel de l'IAP, ainsi que les rôles et l'autorité des représentants de la communauté, que l'inclusion des communautés au sein des structures de l'IAP était purement et simplement une tentative pour préempter et coopter toute forme d'opposition émanant de la classe ouvrière, largement démunie et non propriétaire, au profit d'un projet favorable au secteur privé et mené par l'intermédiaire des IAP. Ils estiment aussi que le nouveau modus operandi de l'État, le partenariat-conciliation, n'a servi qu'à empêcher et à nier l'émergence de toute forme de critique légitime à l'encontre de ce qui était fait contre les communautés ouvrières au nom du renouvellement urbain, présenté à grands renforts de publicité comme un processus entièrement positif et progressiste.

\section{DYNAMIQUES FONCIÈRES, PROJET NÉO-LIBÉRAL ET LOGEMENT SOCIAL}

En 2005, une décennie de boom économique et la raréfaction des terrains à bâtir dans le centre-ville se sont soldées par une hausse marquée du

34. Brudell Paula, Hammond Charlie, Henry Josephine, « Urban planning and regeneration: a community perspective", op.cit.; Kelly Sinéad, MacLaran Andrew, "The Residential Transformation of Inner Dublin » op. cit.; Department of Finance, Goodbody Review of Area-Based Tax Incentive Renewal Schemes, Dublin, Government of Ireland, 2006. 
220 million euros per ha. Disconcertingly for the tenants of social housing, the rapidly escalating value of inner-city land undermined the very "viability" of social housing as an inner-city land use.

As early as the late 1980s, the central government had obliged local authorities to dispose of their land holdings to private developers to facilitate site assembly and act as an impetus to urban renewal. Sites that had been purchased for social housing or parks was sold, 78 sites in central Dublin being sold for private development during the 1990s. One such sale involved the disposal by Dublin Corporation of the Sheriff Street estate, accommodating 113 dwellings, to a private developer. Adjacent to the highly profitable Custom House Docks International Financial Services Centre, the 4 hectares site was sold in 1994 for just 2.4 million euros, being redeveloped as a mixed commercial and private housing development.

As the neoliberal agenda intensified, a directive in 2003 to local authorities from the central government (Circular PPP, 2/03) instructed them to consider for PPP all social-housing regeneration schemes valued at over 20 million euros. DCC became an enthusiastic proponent of the PPP approach. It owned several social-housing estates in the inner city which were commonly in acute need of refurbishment as a result of chronicallyinadequate maintenance by Dublin Corporation/Dublin City Council (DCC) and which were associated with social problems emanating from the economic dislocation resulting from economic restructuring. These estates were often located in areas which seemed "ripe" for renewal, near to newly-completed infrastructures such as the light-railway, or amenities such as the Phoenix Park. Indeed, in some social-housing estates, DCC seemed to pursue a policy of reducing levels of estate maintenance and management, the de-tenanting of flats and poor allocation policies (involving their becoming "dumping grounds" for tenants who required considerable social support), creating an environment not conducive to continued residency. Thereafter, DCC would seek to enter into a Public-Private Partnership with a developer, who would negotiate to provide a number of social-housing units and community facilities in return for the the ownership of the site and for permission to develop a significantly larger number of private units of accommodation for sale on the open market.

Significantly, the land value given away would often greatly exceed the value of the public sector's return from the "partnership". Yet, this is viewed by the state as a "no-immediate-cost" model. However, the enormous value of the land given to the private developer can be viewed as an "asset- stripping" process in which both the state and poor households on waiting lists for social housing lose out heavily to the interests of property capital. 
prix du foncier, les terrains les moins chers se vendant 24 millions d'euros l'hectare et ceux des très prestigieuses tours de l'hôtel Ballsbridge s'étant vendus, dit-on, 220 millions d'euros l'hectare. Les locataires du parc social ont pris conscience, et ce à leur grande surprise, que la hausse vertigineuse des coûts du foncier en centre-ville menaçait la « viabilité » même du logement social au cœur de la ville.

Dès la fin des années 1980, le gouvernement central a contraint les pouvoirs locaux à mettre leurs réserves foncières du centre-ville à la disposition de promoteurs afin de faciliter les opérations immobilières du secteur privé et d'impulser de la sorte le renouvellement urbain. Les terrains qui ont été acquis pour y construire du logement social ou aménager des parcs publics ont été vendus, 78 terrains situés au centre de Dublin l'ayant été à des promoteurs immobiliers au cours des années 1990. L’une de ces opérations concernait la vente à un promoteur privé par la Dublin Corporation, du domaine de Sheriff Street, comprenant 113 logements. Voisin du très rentable Custom House Docks International Financial Services Centre, ce terrain de 4 hectares a été vendu, en 1994, pour seulement 2,4 millions d'euros et transformé en un complexe comprenant un centre commercial et des logements privés.

Alors que le projet néo-libéral s'intensifiait, en 2003, une directive fut envoyée par l'État central aux pouvoirs locaux (circulaire PPP, 2/03) qui les enjoignait de recourir à des PPP pour tous les programmes de réhabilitation de logement social de plus de 20 millions d'euros. Le DCC devint l'un des plus ardents défenseurs du principe de PPP. Il possédait plusieurs ensembles de logements sociaux dans le centre-ville, qui avaient le plus souvent besoin d'une remise à neuf, du fait d'un manque chronique d'entretien par le Dublin Corporation/Dublin City Council et qui connaissaient des problèmes sociaux liés aux bouleversements consécutifs à la restructuration économique. Ces ensembles se trouvaient souvent dans des zones qui semblaient "mûres » pour le renouvellement urbain, car elles étaient situées à proximité d'infrastructures toutes nouvelles (ligne de tramway par exemple), ou d'équipements comme le Parc Phoenix. En effet, dans certaines résidences, le DCC semble délibérément mener une politique de désengagement en termes d'entretien et de gestion, pousser à la liquidation du parc locatif, et limiter ses dépenses (notamment ces ensembles se sont transformés en "dépotoirs » à locataires en demande particulièrement forte d'aide sociale), ce qui a créé un environnement peu propice pour y vivre de manière durable. Par la suite, le DCC a cherché à mettre en place un PPP avec un promoteur qui négocierait la propriété du terrain et l'autorisation d'y construire un très grand nombre de logements 


\section{St Michael's Estate}

The planned regeneration of St. Michael's social-housing estate of 346 dwellings, built in the early 1970s, provides an example of this PPP process, showing the huge value of land to be transferred to the private-sector developer and the small scale of the return which would have accrued to the public sector, had the original PPP project had taken place.

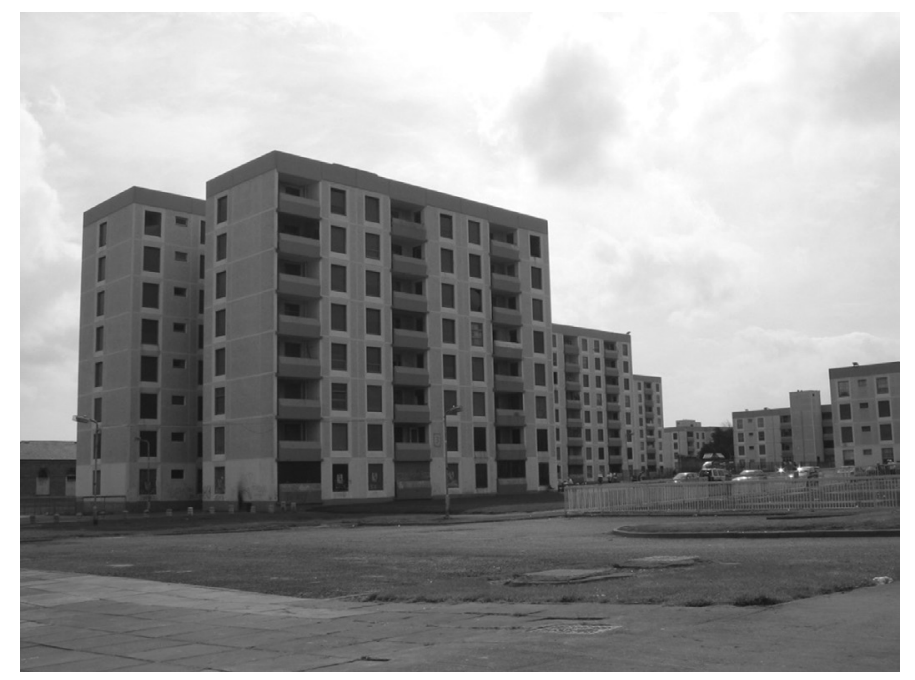

Fig. 2. St. Michael's estate

In St. Michael's, a low-rise redevelopment of the 5.6 hectares site, had been painstakingly agreed following lengthy negotiations between the community and DCC. Under traditional procurement methods, the plan would have yielded 170 social-housing units, 70 units for owner occupation and a further 80 "affordable" private-sector dwellings. However, it was rejected by the central government Department of the Environment (DoE) in 2003 as being too expensive, at a cost of 63 million euros, and DCC was required to engage in negotiations to undertake regeneration through a PPP. Having endured years of blight and neglect and having engaged laboriously and in good faith with the local authority to achieve the agreed regeneration plan, the community was bereft at such a change in policy:

To have it all wrenched away from you like that. It's really terrible. You know, to me it just proves the fact that they don't give a fuck. They really don't. They couldn't care less about people ${ }^{32}$. 
privés aux prix du marché, en échange de la construction de logements sociaux et d'équipements locaux.

De manière très significative, la valeur des terrains ainsi abandonnés au secteur privé excédait souvent largement les bénéfices obtenus par le secteur public dans ce "partenariat ». Or l'État considérait ce modèle comme « sans aucun coût direct ». Pourtant, étant donnée la valeur considérable des terrains abandonnés aux promoteurs privés, on peut y voir au contraire un processus de « dépouillement » par lequel à la fois l'État et les ménages pauvres, sur liste d'attente pour accéder à un logement social, perdent gros au profit du capital immobilier.

\section{St Michael Estate ${ }^{35}$}

Le projet de régénération urbaine des 346 logements sociaux de St Michael, construits au début des années 1970, est un exemple de PPP qui illustre l'importance de la valeur des terrains qui devaient être transférés à un promoteur privé, ainsi que le faible retour pour les pouvoirs publics, si ce projet avait été mené à son terme.

À St Michael, un projet de reconstruction de logements (de faibles densités, sur 5,6 hectares) avait été minutieusement discuté et arrêté au terme d'un long processus de négociation entre la communauté et le DCC. Conformément aux méthodes et à la procédure traditionnelles, le projet aurait concerné 170 logements sociaux, 70 logements en propriété privée et 80 logements privés, à caractère social. Cependant, en 2003, ce projet fut rejeté par l'État central (ministère de l'Environnement), car jugé trop coûteux (63 millions d'euros), et le DCC fut sommé d'engager des négociations pour monter un PPP. Après avoir enduré une situation misérable, après avoir été négligée pendant des années, après s'être engagée difficilement et en toute bonne foi dans un processus de discussion avec le pouvoir local pour concevoir le plan de régénération qui avait été adopté, la communauté locale fut totalement anéantie par ce changement de cap:

Se voir tout arracher des mains comme ça. C'est vraiment terrible. Tu sais, pour moi, ça prouve qu'ils s'en foutent complètement. Vraiment complètement. Ils ne pourraient pas se ficher davantage des gens ${ }^{36}$.

35. Les (Housing) Estates désignent des cités dévolues au logement social en général [NDT].

36. Entretien avec un locataire de St Michael, 2005. 
We had to go back to the residents in the flats and this was after we'd been building them up and convincing them to stay and convincing them that this was the best opportunity for a good house...And you know, people are laughing at us now! They must be! They must be sitting back, thinking we're a right shower of gobshites ${ }^{33}$.

The first PPP plan, which was strongly supported by council officials, involved the transfer of ownership of the site to a private-sector partner, who would act as the developer. In return, the developer would give 80 units of new social-housing units to the local authority and build a further 770 private-sector dwellings (550 at open-market prices and a further 220 at an "affordable" rate for owner occupation). Thus, the loss of social-housing units would be considerable, amounting to some 266 dwellings.

The rejection of the original negotiated plan by the DoE and the imposition of a PPP in which the community was to have no influence in its design, led to the organization of a range of protests by the community (see Figure 3) and elicited the following observations from residents:

The attitude in St. Michael's Estate is "This is the way we're doing it and you either like it or you don't like it, but irrespective, it's being done that way regardless". There's absolutely no consultation actually takes place ${ }^{34}$.

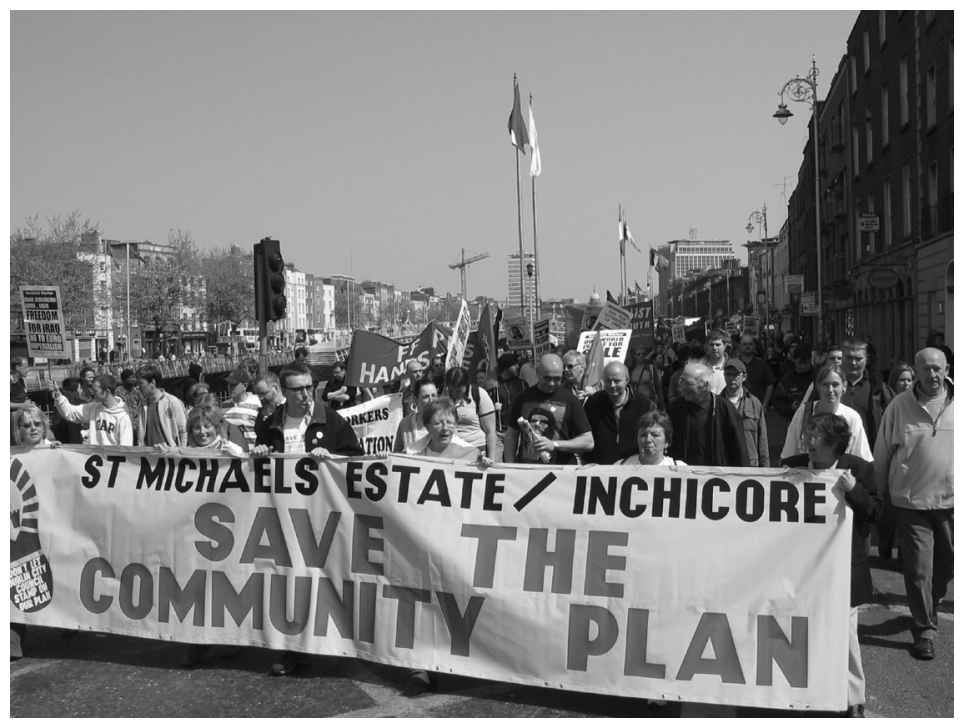

Fig. 3. Community protest to reinstate the original agreed regeneration plan

33. Interview, Tenant Activist, St. Michael's Estate, 2005.

34. Interview, Tenant Activist, St. Michael's Estate, 2005. 
Nous avons dû retourner voir les gens chez eux, après qu'on avait fait tant d'efforts pour les convaincre de rester et que c'était une excellente occasion d'avoir un bon logement... Et tu sais, les gens se moquent de nous maintenant! C'est bien leur droit! Ils peuvent nous regarder de loin en pensant que nous sommes un beau tas de peigne-culs ${ }^{37}$.

Le premier projet de PPP, qui fut fermement défendu par les fonctionnaires municipaux, prévoyait le transfert de propriété du terrain à un partenaire privé qui jouerait le rôle de promoteur. En échange, ce dernier devait donner 80 logements sociaux neufs aux pouvoirs locaux et construire 770 logements privés (550 au prix du marché et 220 plus accessibles, tous en pleine propriété privée). La perte de logement social, soit 266 logements, aurait donc été au total considérable.

Le rejet du plan d'origine et le fait qu'un PPP ait été imposé sans que la communauté ait son mot à dire, ont suscité le commentaire suivant de la part des résidants:

L'attitude à St Michael c'est: "c'est comme ça qu'on fait, et que vous aimiez ça ou non, de toutes manières, c'est comme ça qu'on va procéder ». En fait, il n'y a absolument aucune consultation ${ }^{38}$.

Les intentions du conseil municipal, devinrent alors claires et aisément compréhensibles pour les résidants, comme le résume bien cette citation:

Ils ne veulent pas faire appel à nous. Nous sommes le passé, nous ne sommes même plus le présent, nous sommes le passé. Le futur est totalement différent et nous n'en faisons pas partie. Ou bien ils ne semblent pas du tout vouloir nous y inclure. Ils sont très satisfaits de disperser les pauvres dans toute la ville pour cacher le problème de la pauvretés ${ }^{39}$.

37. Entretien avec un locataire activiste de St Michael, 2005.

38. Entretien avec un locataire activiste de St Michael, 2005.

39. Entretien avec un locataire de St Michael, 2005. 
The intentions of the City council became clear and readily comprehended by the residents, encapsulated in the following quotation :

They're not interested in appealing to us. We're the past, we're not even the present any more, we're the past. The future is something totally different and it doesn't include us. Or they certainly don't seem to want to include us. They're quite happy to disperse people who live in poverty around the city so they can hide the problem of poverty ${ }^{35}$.

It's like well you know "This is the way we're doing it and you either like it or you don't like it, but irrespective, it's being done that way regardless". There's absolutely no consultation actually takes place ${ }^{36}$.

Indeed, PPPs are inherently contrary to real community participation because the financial details are always kept confidential for reasons of "commercial sensitivity" of the private-sector partner.

Interestingly, it seems that the first PPP plan was drawn up by council officials in the absence of any independent valuation of the site $e^{37}$. It was eventually conceded by officers of the Council that just 4.6 hectares of the 5.6 hectares site had a value of at least 70 million euros ${ }^{38}$. Estimates by private-sector valuation surveyors of the true value of the land which would have been transferred under the first PPP deal range from 80 million to 130 million euros, the estate being situated just 3 kilometers from the city centre and linked to it by a newly-completed light-rail line. Yet, in return, the state would obtain just 80 units of social housing, worth less than 20 million euros!

However, as a postscript to this section, the almost total reliance placed by DCC on PPPs to effect its social-housing regeneration has recently been thrown into turmoil. PPPs rely on the private sector's ability to generate sufficient profit from the redevelopment of the land (for private commercial or residential space) to allow the developer also to provide a "social yield" in the form of new social housing. The collapse of the property market in Ireland during 2007 and 2008, with an estimated 20,000 vacant residential units lying on the market in Dublin, caused the private-sector

35. Interview, Tenant, St. Michaels Estate, 2005.

36. Interview, Tenant, St. Michaels Estate, 2005.

37. Kelly Sinéad, Maclaran Andrew, "The Residential Transformation of Inner Dublin", op. cit.

38. Punch Michael, Redmond Declan, Kelly Sinéad, "Globalization, urban governance and the inner city: lessons from Dublin", in Governing Cities in a Global Era: Urban Innovation, Competition and Democratic Reform, Gross Jill, HambleTON Robin (dir.), New York, Palgrave, 2007. 
En effet, par définition, le principe du PPP est contraire à celui d'une réelle participation communautaire car les données financières sont confidentielles à cause de la «sensibilité commerciale » des partenaires privés.

Il est intéressant de noter que le premier projet de PPP fut conçu par des fonctionnaires municipaux en l'absence de toute évaluation indépendante pour établir la valeur du terrain ${ }^{40}$. Des fonctionnaires municipaux finirent par admettre que 4,6 hectares des 5,6 hectares du terrain valaient à eux seuls au moins 70 millions d'euros ${ }^{41}$. Des estimations faites par des experts privés concluent que la valeur réelle du terrain qui aurait dû être transféré au secteur privé dans le cadre de ce premier accord de PPP était de 80 à 130 millions d'euros, le terrain étant situé à 5 kilomètres du centre-ville et relié à lui par une nouvelle ligne de train. Pourtant, en retour, l'État n'aurait obtenu que 80 logements sociaux valant moins de 20 millions d'euros.

Néanmoins, en guise de conclusion provisoire, on peut noter que la stratégie du DCC qui consistait à s'appuyer entièrement sur des PPP pour réhabiliter son parc de logement social, a récemment été bouleversée. Les PPP s'appuient en effet sur la capacité du secteur privé à engendrer assez de profit (en construisant sur les terrains des bâtiments commerciaux ou résidentiels) pour qu'il y ait aussi un "rendement social », le promoteur fournissant également du logement social. Or l'effondrement du marché immobilier en Irlande en 2007-2008 (on estime qu'il y a 20000 logements vacants sur le marché à Dublin) a poussé le secteur privé à se retirer totalement, à la mi-2008, de cinq projets de régénération de logements sociaux dans le cadre de PPP. L'avenir de ces projets et des résidants est pour l'instant fait d'incertitude.

40. Kelly Sinéad, MacLaran Andrew, "The Residential Transformation of Inner Dublin ", op. cit.

41. Punch Michael, Redmond Declan, Kelly Sinéad, "Globalization, urban governance and the inner city: lessons from Dublin », in Governing Cities in a Global Era: Urban Innovation, Competition and Democratic Reform, Gross Jill, HAмBLETon Robin (dir.), New York, Palgrave, 2007. 
partner for five social-housing regeneration PPPs to withdraw completely in mid 2008. Uncertainty currently (October 2008) surrounds the future for those schemes and for their residents.

\section{Gentrification as Urban Strategy}

The overwhelming outcome of an increasingly neoliberal central state and an entrepreneurial local state, which has become a more-than-willing "agent" of capital39, has been the widespread gentrification of inner Dublin $^{40}$. This section outlines the extent to which the built environment and the social landscape of the inner city have changed since the early 1990s. It maintains that the process of gentrification has deepened in recent years as the implementation of local-area planning and as social-housing regeneration create displacement through the direct replacement of a working-class population by young, professional owner occupiers and as a commitment to "social mix" in formerly-deprived areas of the city is realised through a policy of "social cleansing".

Since the introduction of tax-incentives for property development in the mid-1980s and the re-orientation of the local state towards more entrepreneurial forms of urban governance, the inner city has experienced an unprecedented influx of capital, largely in the form of private residential development. Having experienced negligible levels of private-sector residential development during the twentieth century, the inner city saw the construction of 16,500 new private residential units between 1989 and the end of $2003^{41}$. These new developments predominantly consist of private apartment complexes, a large majority (circa $92 \%$ ) of which are either oneor two-bedroomed units ${ }^{42}$. New and re-imagineered residential spaces have appeared in many former industrial areas including Dublin's docklands, the Liberties (south-west inner city) and the north-west inner city.

39. Sмітн Neil, «New Globalism, New Urbanism: Gentrification as Global Urban Strategy», in Antipode, nº 34 (3), 2002, p. 434-457.

40. Kelly Sinéad and Maclaran Andrew, "The Residential Transformation of Inner Dublin", op.cit., p. 36-59; Punch Michael, Redmond Declan and Kelly Sinéad, "Globalization, urban governance and the inner city: lessons from Dublin", op. cit.

41. Kelly Sinéad and MacLaran Andrew, "The Residential Transformation of Inner Dublin", op. cit.

42. Ibid. 


\section{LA GENTRIFICATION COMME STRATÉGIE URBAINE}

La conjugaison de l'action d'un État central néo-libéral et d'un pouvoir local entrepreneurial, devenu agent "plus que volontaire» du capital ${ }^{42}$, s'est traduite par une gentrification à grande échelle du centre de Dublin ${ }^{43}$. Dans cette partie, nous montrons à quel point l'environnement bâti et le paysage social du centre-ville ont changé depuis le début des années 1990. Nous soutenons que le processus de gentrification s'est accentué au cours des dernières années: la mise en œuvre de politiques urbaines locales et la réhabilitation du parc social ont en effet conduit à remplacer les populations ouvrières par des propriétaires jeunes issus des couches moyennes et supérieures. L'objectif de mixité sociale dans les quartiers autrefois déshérités est mis en œuvre à travers une politique de "nettoyage social ».

Depuis l'introduction d'incitations fiscales en faveur de l'immobilier au milieu des années 1980 et l'infléchissement vers une gouvernance urbaine locale plus entrepreneuriale, le centre-ville a connu un afflux d'investissement sans précédent, essentiellement sous la forme de construction de logements. Alors que l'investissement privé au centre-ville avait été négligeable tout au long du $\mathrm{xx}^{\mathrm{e}}$ siècle, 16500 nouveaux logements privés y ont été construits entre 1989 et la fin $2003^{44}$. Ces opérations immobilières consistent principalement en des programmes d'habitat collectif, majoritairement des appartements de deux à trois pièces (environ $92 \%)^{45}$. De nouveaux types d'espaces résidentiels ont été " réinventés » dans nombre d'anciens quartiers industriels, notamment dans les Docks, les Liberties (au sud-ouest du centre-ville) et au nord-ouest du centre-ville.

L'afflux d'investissement dans le centre de Dublin s'est accompagné d'un afflux de population (112 076 personnes, soit une augmentation de 33,3 \%).

42. Sмiтн Neil, «New Globalism, New Urbanism: Gentrification as Global Urban Strategy », in Antipode, n 34 (3), 2002, p. 434-457.

43. Kelly Sinéad, MacLaran Andrew, "The Residential Transformation of Inner Dublin », op. cit., p. 36-59; Punch Michael, Redmond Declan, Kelly Sinéad, "Globalization, urban governance and the inner city: lessons from Dublin », op. cit.

44. Kelly Sinéad and MacLaran Andrew, « The Residential Transformation of Inner Dublin », op. cit.

45. Ibid. 
The influx of capital to inner Dublin has been accompanied by an influx of population, the inner area experiencing a population increase of 33.3\% to 112,076 persons between 1991 and 2002. This shift in demographics is significant, as the population of the inner city had been decreasing since the 1930s with slum clearance.

Research into the occupiers of the first phase of residential developments (1989-1996) clearly showed the emergence of a gentrifying population, displaying socio-economic characteristics quite distinct from those of the indigenous population which was typically elderly, poorly skilled and suffering from a high incidence of unemployment ${ }^{43}$. The new population had few links with the locality. It was predominantly youthful, with $94 \%$ of residents being aged between 18 and 44 years, having an average age of 27 years. Households were small in size, averaging 1.9 persons with $80 \%$ comprising just 1 or 2 people. Professionals accounted for $48 \%$ of the new residents, clerical workers and students accounted for $14 \%$ and $9 \%$ respectively. A majority (77 \%) held, or were currently pursuing, a degree or professional qualification.

Recent census results confirm that the process of gentrification has gathered momentum ${ }^{44}$. The dramatically altered socio-economic composition of the inner city's population is revealed by changes in its age structure, social class, levels of achieved education, employment rates and housing tenure. The 33\% increase in population can be attributed almost entirely to the net in-migration of young professionals. Between 1991 and 2002 , the inner city experienced a $90 \%$ increase in the number of adults aged between 25 and 44 years to 45,107 persons. This cohort accounted for $40 \%$ of the population in 2002, up from $30 \%$ in 1991 . Simultaneously, the number of children and elderly persons has fallen ${ }^{45}$.

43. Maclaran Andrew, Maclaran Morag and Williams Brendan, Residential development as an engine for inner-city renewal in Dublin: commentary and statistical appendix, Dublin, Centre for Urban and Regional Studies, Trinity College Dublin, 1994; MacLaran Andrew, Emerson Harriet and Williams Brendan, Residential development in central Dublin: a survey of current occupiers, Dublin, Centre for Urban and Regional Studies, Trinity College Dublin, 1995; MacLaran Andrew and FloYD David, A report on the recent residential developments in central Dublin: March 1996, Dublin, Centre for Urban and Regional Studies, Trinity College Dublin, 1996.

44. Central Statistics Office (CSO), Census of Population, 2002, Dublin, Stationery Office, 2002.

45. Kelly Sinéad and Maclaran Andrew, "The Residential Transformation of Inner Dublin", op. cit. 
Ce retournement démographique est d'autant plus significatif que la population du centre-ville déclinait depuis les années 1930 du fait de la résorption des taudis.

L'étude du profil des occupants de la première phase de construction (1989-1996) a révélé l'émergence d'une population de « gentrifieurs » aux caractéristiques socio-économiques très différentes de celles de la population d'origine, plutôt âgée, peu qualifiée et particulièrement touchée par le chômage ${ }^{46}$. La nouvelle population avait peu de liens avec le territoire local. Elle était jeune, avec $94 \%$ de résidants âgés de 18 à 44 ans pour une moyenne d'âge de 27 ans. Les ménages, de petite taille (en moyenne 1,9 personnes), se composaient à $80 \%$ de 1 ou 2 personnes. Les cadres représentaient $48 \%$ des nouveaux habitants; les employés et les étudiants, respectivement 14 et $9 \%$. La majorité des habitants $(77 \%)$ détenait ou préparait alors un diplôme ou une qualification supérieure.

Les résultats du dernier recensement confirment que le processus de gentrification s'est accentué ${ }^{47}$. Le profond changement des caractéristiques socio-économiques de la population du centre-ville se manifeste par des transformations de la structure par âge, de l'appartenance sociale, du niveau de formation, des taux d'emploi et du statut d'occupation des logements. L'augmentation d'un tiers de la population peut être intégralement attribuée au solde migratoire positif de jeunes cadres. Entre 1991 et 2002, le centre-ville a connu une augmentation de $90 \%$ du nombre d'adultes (25 à 44 ans), soit plus de 45000 personnes. Ce groupe représentait $40 \%$ de la population en 2002, contre $30 \%$ en 1991. Dans le même temps, le nombre d'enfants et de personnes âgées a chuté ${ }^{4}$.

Une analyse plus pointue des changements de la composition sociale révèle une augmentation significative du nombre de personnes apparte-

46. Maclaran Andrew, MacLaran Morag et Williams Brendan, Residential development as an engine for inner-city renewal in Dublin: commentary and statistical appendix, Dublin, Centre for Urban and Regional Studies, Trinity College Dublin, 1994; Maclaran Andrew, Emerson Harriet et Williams Brendan, Residential development in central Dublin: a survey of current occupiers, Dublin, Centre for Urban and Regional Studies, Trinity College Dublin, 1995; MacLaran Andrew et Floyd David, A report on the recent residential developments in central Dublin: March 1996, Dublin, Centre for Urban and Regional Studies, Trinity College Dublin, 1996.

47. Central Strategic Office (CSO), Census of Population, 2002, Dublin, Stationery Office, 2002.

48. Kelly Sinéad, Maclaran Andrew, "The Residential Transformation of Inner Dublin », op. cit. 
Concentrating on changes in Social-Class composition, a substantial rise in the number of persons in the upper Social Classes 1-3 of 75\% to 45,112 is noted, whilst a drop in the number of persons in the lower Social Classes 4-6 of $24 \%$ to 29,177 was registered. Furthermore, 39\% of those aged between 25 and 44 years belong to Social Classes 1 and 2, representing a proportionate increase of $18 \%$ since 1991 . Other changes, which clearly support an interpretation of inner-city gentrification, relate to changes to levels of post-secondary education. In 2002, 27,090 persons had received third-level education. The corresponding figure for 1991 had been a mere 6,581 persons.

Another indication that the inner city is undergoing a process of gentrification is the changing tenure structure of the city's dwelling stock. Since 1991, there have been two notable changes to the tenure structure: a substantial increase in the number of households in privately-rented accommodation, which has more than doubled from 5,611 to 13,272 households ${ }^{46}$ and a $20 \%$ reduction in the number of households in social housing to 8,111 units, a result of the sale or privatisation of existing stock and the decline in the number of new social-housing units being constructed. This decline in the provision of social housing has had serious implications for inner-city residents, leading to an intensified housing-affordability crisis and the displacement of the indigenous population.

\section{Affordability and Displacement}

Changes to the social profile of the inner city are linked directly to a decline in housing affordability. In inner Dublin, house prices escalated in the early 1990s and have continued to spiral. New house prices in 1995-6 were still remarkably affordable when expressed in terms of multipliers of prevailing incomes. At the lower end of the market, one-bedroomed apartments could be purchased for less than twice the level of average industrial earnings, which amounted to 20,342 euros in May of that year, whilst the cost of higher-end one-bedroomed apartments was just over five times the

46. The increase in privately-rented accommodation over owner-occupied accommodation may be attributed to the high incidence of tax-incentive take-up by investors and developers rather than home-owners, and runs contrary to what may have been expected considering the high levels nationally of owner- occupied housing (almost $80 \%$ of households compared to $32 \%$ in inner Dublin in 2002). It is estimated that investors bought $80 \%$ of the residential developments that qualified for tax incentives under the Urban Renewal Schemes (Department of Finance, 2006). 
nant aux classes supérieures (catégories 1 à 3 du recensement) $(+75 \%$, soit plus de 45000 personnes), tandis qu'une baisse du nombre de personnes appartenant aux classes moins aisées (catégories 4 à 6) a été enregistrée ($24 \%$, soit plus de 29000 personnes). De plus, $39 \%$ des personnes âgées de 25 à 44 ans appartiennent aux classes supérieures (catégories 1 et 2), soit une croissance de $18 \%$ depuis 1991. Les changements dans le niveau de formation supérieure, de la population confirment l'hypothèse d'une gentrification du centre-ville. En 2002, plus de 27000 personnes étaient passées par l'enseignement supérieur. En 1991, elles étaient moins de 6600.

Le processus de gentrification en cours dans le centre-ville se manifeste également par le changement de statut d'occupation dans le parc de logements de la ville. Depuis 1991, on constate deux évolutions très importantes: une augmentation substantielle du nombre de ménages locataires dans le parc privé, leur nombre ayant plus que doublé, passant de 5600 à $13300^{49}$, et une réduction de $20 \%$ du nombre de ménages locataires dans le parc social (ramenés à 8100 environ), du fait de la vente ou de la privatisation du parc existant ainsi que du ralentissement de la construction de nouveaux logements. Ce déclin de l'offre de logement social a eu de graves conséquences sur les résidants du centre-ville, car il a conduit à une grave crise du logement et au déplacement de la population originelle du quartier.

\section{Logement abordable et déplacement}

Les changements sociaux au centre-ville sont directement liés au déclin de l'offre de logement abordable. Dans le centre de Dublin, les prix des logements ont connu des hausses vertigineuses au début des années 90 et la spirale ascendante se poursuit. Les prix des logements neufs en 1995-1996 étaient encore remarquablement abordables par rapport au revenu des habitants. Un appartement de deux pièces, bas de gamme, valait moins de deux fois le revenu annuel moyen dans l'industrie (20342 euros en mai 1995). Le prix d'un deux pièces haut de gamme s'établissait juste au

49. L'augmentation des logements locatifs par rapport aux logements privatifs peut être mise en lien avec le fait que les avantages fiscaux sont plus élevés pour les investisseurs et les promoteurs que pour les propriétaires-occupants. Elle peut paraître surprenante au regard de la forte proportion des propriétaires-occupants à l'échelle nationale (près de $80 \%$ des ménages, contre $32 \%$ à Dublin en 2002). On estime que les investisseurs ont acheté $80 \%$ des constructions résidentielles qui bénéficiaient des avantages fiscaux accordés par le Programme de Renouvellement Urbain (Department of Finance, 2006). 
average industrial wage ${ }^{47}$. For white-collar workers, three-bedroomed units could be purchased for less than four times average earnings in the Banking, Insurance and Building Society (25,584 euros).

Between 1995 and 2002, the Consumer Price Index rose by 25\%, average earnings rose nationally by $43 \%$ and building costs increased by $52 \%$. Meanwhile, new house prices rose nationally by $181 \%$. However, the changes in the housing market in inner Dublin were far more dramatic.

By June 2003, average annual industrial earnings had risen by $46 \%$ compared to May 1995 to reach 29,671 euros per annum, while earnings in the Banking, Insurance and Building Society sector increased by $44 \%$ to 36,806 euros. Despite these increases well above the rate of general price inflation, the income multipliers required to purchase a dwelling in central Dublin by November 2003 suggest strongly that prices were far less affordable than eight years previously. One-bedroomed cost nine times the level of average annual industrial earnings. Three-bedroomed units cost 14 times average annual industrial earnings. Even for the white-collar sector, one-bedroomed apartments cost six times average annual incomes while three-bedroomed units ranged from 11 to over 19 times average white-collar annual incomes. By 2006, new one- and two-bedroomed apartments in the Liberties commanded prices of 385,000 euros and 420,000 euros respectively.

Rising residential prices are also apparent in the second-hand apartment market (see Figure 4). In 1995, one-bedroomed apartments in The Maltings in the Liberties had a Euro-equivalent launch price of 38,100 euros. In 2004 , the same development were being re-sold at 187,000 euros. Furthermore, increasing house prices have also impacted on the older, nineteenth century stock. For example, a one-bedroomed, 45 square meters cottage in Daniel Street in the Liberties sold for 475,000 euros in July 2006.

Such prices indicate the scale of the affordability crisis facing indigenous residents. Indeed, there is evidence to suggest that the first-phase residential developments (1989-1996) have themselves since been gentrified. While it can be argued that some of the indigenous residents gain from

47. Kelly Sinéad and Maclaran Andrew, "The Residential Transformation of Inner Dublin", op. cit. 
dessus de cinq fois ce même revenu ${ }^{50}$. Les salariés du secteur des services pouvaient acheter un appartement de 4 pièces pour moins de 4 fois le revenu moyen dans le secteur de la banque, de l'assurance et de l'immobilier (25 584 euros).

Entre 1995 et 2002, l'indice des prix à la consommation a augmenté de $25 \%$, les revenus moyens de $43 \%$ au niveau national et les coûts de construction de $52 \%$. Dans le même temps, les prix des logements neufs ont connu une croissance de $181 \%$ au niveau national. Pourtant, les évolutions du marché du logement dans le centre de Dublin ont été de loin plus prononcées.

En juin 2003, le revenu industriel annuel moyen avait grimpé de $46 \%$ par rapport à mai 1995, pour atteindre 29671 euros par an, tandis que les revenus dans le secteur de la banque, assurance et immobilier avaient augmenté de $44 \%$, soit 36806 euros. En dépit de ces évolutions bien supérieures au taux d'inflation global, les revenus requis pour acheter un logement dans le centre de Dublin montrent que les prix étaient beaucoup moins abordables que 8 ans plus tôt. Un logement de deux pièces coûte neuf fois le revenu moyen dans l'industrie et un logement de quatre pièces, 14 fois. Même dans le secteur des services, les appartements de deux pièces coûtent six fois les revenus annuels tandis que le prix des logements de quatre pièces s'échelonne entre 11 et 19 fois le revenu moyen annuel dans ce secteur. En 2006, les logements neufs de deux et trois pièces affichaient des prix allant de 385000 à 420000 euros.

La hausse des prix dans l'immobilier résidentiel est aussi visible sur le marché de la revente. En 1995, les appartements de deux pièces aux Maltings dans les Liberties étaient vendus à un prix plancher de 38100 euros. En 2004, le même programme affichait des prix de revente à 187000 euros. De plus, la hausse des prix a également eu un impact sur le parc ancien du XIX ${ }^{e}$ siècle. Par exemple, un cottage de deux pièces d'une surface de $45 \mathrm{~m}^{2}$ à Daniel Street dans les Liberties s'est vendu pour 475000 euros en juillet 2006 .

De tels prix sont révélateurs de la crise du logement à laquelle les anciens résidants sont confrontés. En effet, certains signes montrent que les premiers programmes résidentiels (1989-1996) ont eux-mêmes connu un processus de gentrification depuis leur construction. On peut certes en conclure qu'une partie des habitants d'origine ont bénéficié de l'augmenta-

50. Kelly Sinéad, MacLaran Andrew, "The Residential Transformation of Inner Dublin », op. cit. 
rising residential values, others who do not stand to gain by virtue of their inability to access property capital. For this group, escalating prices present an insuperable obstacle to gaining access to accommodation.

Access to housing for the indigenous population has also been hampered by recent policies adopted by the local state in its pursuit of a neo-liberal urban agenda and it is to these policies that this section now turns.

\section{The State as Agent of Gentrification}

In addition to promoting property renewal through tax incentives and sale of publicly-owned sites, the local state has embraced the role of "enabler" and "facilitator" in the redevelopment of the inner city ${ }^{48}$. A process of sanitization of the inner-city has been initiated in which the local state has been an active agent in the process of gentrification, creating new residential, commercial and cultural spaces often at the expense of former lowergrade residential, commercial and cultural spaces. The privatisation of public housing and the displacement of working-class residents have been effected through the adoption of a PPP approach to social-housing regeneration and through micro-area planning via IAPs.

Additionally, in recent years, the justification for the sale of public land by the local authority has evolved to reflect principles of short-term accounting, an ideology of "social mixing" and an unwillingness by DCC to provide and manage additional social-housing units. The overwhelming result of this policy ${ }^{49}$ has been a reduction in the social-housing stock with bleak prospects for the future provision of additional public-rented units in the inner city.

48. Harvey David, "From managerialism to entrepreneurialism: the transformation in urban governance in late Capitalism", in Geografiska Annaler B, 71, 1989, p. 13-17; Punch Michael, Redmond Declan and Kelly Sinéad, "Globalization, urban governance and the inner city: lessons from Dublin", op. cit.

49. While Dublin City Council claims that it is unable to provide social housing because of a lack of sites in its ownership for such development, it pursues a policy of de facto transfer of land to private-sector developers, notably through continuing land sales and public-private partnerships. 
tion des valeurs immobilières, mais d'autres résidants sont exclus de ce bénéfice du fait de leur incapacité financière à accéder à la propriété. Pour ces derniers, la hausse des prix constitue un obstacle infranchissable à l'accès au logement.

Les politiques récemment adoptées par les autorités locales dans leur application d'un programme urbain néo-libéral ont également rendu plus difficile l'accès au logement pour la population d'origine. Ce sont ces politiques que la partie suivante va examiner.

\section{Les pouvoirs publics comme acteurs de la gentrification}

Au-delà de leur action en faveur de la revalorisation du marché foncier à travers des incitations fiscales et la vente de terrains publics, les autorités locales ont adopté un rôle d' "agent catalyseur " et de "facilitateur » du renouvellement urbain du centre-ville ${ }^{51}$. Un processus d'assainissement du centre a été engagé, dans lequel la municipalité joue un rôle actif dans la gentrification, créant de nouveaux espaces résidentiels, commerciaux et culturels, souvent aux dépens des territoires résidentiels, commerciaux et culturels autrefois peu valorisés. La privatisation du logement social et le déplacement de la population ouvrière ont été mis en œuvre à travers l'adoption d'une approche de la rénovation du logement social fondée sur le partenariat public - privé et par des politiques urbaines à l'échelle microlocale, via les IAP.

Par ailleurs, ces dernières années, la vente des propriétés foncières publiques est de plus en plus justifiée par des principes comptables à court terme, une idéologie de la «mixité sociale » et la volonté du conseil municipal de Dublin de ne plus construire ni gérer de nouveaux logements sociaux. Le résultat de cette politique ${ }^{52}$ a été une réduction massive du parc de logement social et un avenir peu engageant pour l'offre future de logement locatif public dans le centre-ville.

51. Harvey David, «From managerialism to entrepreneurialism: the transformation in urban governance in late Capitalism ", in Geografiska Annaler B, $\mathrm{n}^{\circ} 71$, 1989, p. 13-17; Punch Michael, Redmond Declan et Kelly Sinéad, «Globalization, urban governance and the inner city: lessons from Dublin », op. cit.

52. Tandis que le conseil municipal de Dublin affirme qu'il n'est pas en mesure de fournir du logement social sous prétexte qu'il ne possède pas de terrains pour réaliser ce type de programme, il mène de facto une politique de transfert de terrain aux promoteurs privés, en continuant notamment à vendre des terrains et à favoriser les partenariats public-privés. 
Recent policy documents, for example the Dublin City Development Plan $^{50}$, Part V of the Planning and Development Act ${ }^{51}$ and the Integrated Area Plans $s^{52}$, are all concerned with the promotion of "social mix", "tenure mix" and the avoidance of "undue social segregation" in the inner city. This policy of social mixing seems to be founded on an inherent belief that the introduction of middle-class residents into working-class areas will prove beneficial to the recipient community. This assumption can itself be criticised for its overtly ideological basis and for its failure to recognise the problems and difficulties thereby created for that community.

Nevertheless, there seems to exist a pervasive belief among policy makers that "social mix" can be achieved through the introduction of private residential development to areas with previously high concentrations of social housing. In effect, this "social mix" or social engineering policy is being employed as a tool for legitimising the privatisation of land and housing in the inner city.

Furthermore, Dublin City Council has interpreted the "avoidance of undue social segregation" as meaning that no additional local-authority housing should be developed in those areas already possessing high proportions of social housing (greater than $50 \%$ of dwellings). Up to April 2004, this policy of zero social housing in areas of high concentration had effectively excluded 15 of the 40 wards of the inner city from receiving any addition to its social housing stock.

Interestingly, this attempt at social engineering through the introduction of a middle-class population to poor areas is a highly selective and exclusionary policy, any one-class concentrations of middle-class or upperincome residential areas being excluded from its concern. In Ireland, where one of the strongest spatial indicators of social deprivation is the presence of social housing, this represents the withdrawal of a key element of welfare-state support from areas in which the need for assistance is most acute.

50. Dublin Corporation, Integrated Area Plans: Urban Renewal Tax Incentive Scheme 1999 (Leaflets), Dublin, Dublin Corporation, 1999.

51. Department Of The Environment, Planning and Development Act 2000, Dublin, Stationery Office, 2000.

52. Dublin Corporation, Liberties/Coombe Integrated Area Plan, op. cit. 
Les documents de planification récents, par exemple le Plan de Développement de la Ville de Dublin ${ }^{53}$, le volet $\mathrm{V}$ de la Loi sur le Développement et la Planification ${ }^{54}$ et les Plans Intégrés de Secteurs ${ }^{55}$, mettent tous en avant l'objectif de "mixité sociale», de "mixité de statuts d'occupation» et la lutte contre la «ségrégation sociale excessive» dans le centre-ville. Cette politique de mixité sociale semble fondée sur cette croyance fondamentale: l'arrivée de résidants issus des couches moyennes et supérieures dans les quartiers ouvriers ne peut être que bénéfique pour leurs habitants. On peut critiquer cette hypothèse pour son fondement clairement idéologique et pour son incapacité à prendre en compte les problèmes et difficultés qui en découlent pour la population du quartier.

Pourtant, au sein des pouvoirs publics, semble prévaloir très fortement cette conviction: la mixité sociale peut être atteinte en développant des programmes résidentiels privés dans des secteurs où domine le logement social. En fait, les politiques de «mixité sociale » ou d'ingénierie sociale sont utilisées comme des outils de légitimation de la privatisation des terrains et du logement dans le centre-ville.

De plus, le conseil municipal de Dublin a interprété « la lutte contre une ségrégation excessive " comme une injonction à ne plus développer de logement social municipal dans les secteurs où il existait déjà de fortes concentrations de logement social (plus de $50 \%$ du parc). Jusqu'à avril 2004, cette politique de " zéro logement social » dans ces secteurs a de fait empêché 15 des 40 quartiers du centre-ville (wards) de bénéficier de la construction du moindre logement social.

On peut noter que cette tentative d'ingénierie sociale par l'apport de population des classes moyennes dans les quartiers pauvres est une politique très sélective et exclusive puisque les quartiers où sont concentrées les classes moyennes ou supérieures ne sont pas du tout concernés par les politiques de mixité. En Irlande, où l'un des indicateurs spatiaux les plus significatifs de la pauvreté est la présence de logement social, ces politiques sont le signe du retrait d'un des éléments-clés de l'aide de l'État de quartiers où le besoin d'intervention est le plus criant.

53. Dublin Corporation, Integrated Area Plans: Urban Renewal Tax Incentive Scheme 1999 (Leaflets), Dublin, Dublin Corporation, 1999.

54. Department of the Environment and Local Government, Planning and Development Act 2000, Dublin, Stationery Office, 2000.

55. Dublin Corporation, Liberties/Coombe Integrated Area Plan, op. cit. 


\section{Gentrification as Strategy}

Gentrification has been adopted by the state as a more general urban strategy. In preparing and selling the city for capital, the state is actively involved in seeking to attract a middle-income professional population to live in the inner city. Recent planning and housing policies are being employed as a tool to "civilise ${ }^{53}$ " or socially to "cleanse" Dublin's inner city. A major result has been the intensification and entrenchment of the gentrification of inner Dublin. More specifically, the adoption of policies which seek to reduce the stock of local-authority housing in the city are aimed at displacing low-income families from the inner area to more peripheral parts of the city. One of the ways in which processes of gentrification (or more broadly the uneven movement of capital) can be mitigated is through the provision of social housing in the inner city. However, the local state is instead freeing up public land for capital exploitation and withdrawing from housing provision through the sale of local-authority houses and flats, the reduction of the stock through PPP redevelopment, a growing reliance on the privately-rented and voluntary-housing sectors to provide accommodation for low-income households and through the sale of sites earmarked for social-housing provision.

Dublin's inner city has become symbolic of the underlying social transformation that has taken place. Through policies of gentrification, "sugarcoated" as regeneration, locales and streets have been physically recast and "re-imagineered" as spaces for middle-class consumption ${ }^{54}$. The re-focusing of priorities of the neoliberal local state has been reflected in a redistribution and channeling of wealth through the built environment. It is in this way that it could be argued that neoliberalism is embodied in new urban redevelopment projects and that Dublin, in its physical form, is increasingly representative of a neoliberal agend ${ }^{55}$.

53. WARD Kevin, "Entrepreneurial urbanism, state restructuring and civilising 'New' East Manchester", in Area, 35 (20), 2003, p. 116-127.

54. Sмiтн Neil, "New Globalism, New Urbanism: Gentrification as Global Urban Strategy", op. cit.

55. Brenner Neil and Theodore Nik, "Cities and the geographies of 'actually existing neoliberalism”, in Antipode, 34 (3), 2002, p. 356-386; Swyngedouw Eric, "Governance Innovation and the Citizen: The Janus Face of Governance-beyondthe-State ", in Urban Studies, no 42 (11), 2005, p. 1991-2006. 


\section{La gentrification comme stratégie}

La gentrification a été adoptée par les pouvoirs publics comme une stratégie urbaine plus globale. En préparant et en vendant la ville au bénéfice du capital, les autorités sont activement impliquées dans une politique visant à attirer une population de cadres à revenus moyens dans le centreville. La planification urbaine comme les politiques du logement ont récemment été utilisées comme un outil pour " civiliser $^{56}$ » ou pour « nettoyer » socialement le centre de Dublin. Il en est résulté une intensification et une généralisation de la gentrification du centre-ville. Plus précisément, l'adoption de politiques visant à réduire le parc de logements publics locaux a pour but de déplacer les familles à bas revenus du centre vers des secteurs plus périphériques de la ville. L'un des moyens d'atténuer les processus de gentrification (ou plus largement les effets de la volatilité spatiale du capital) est de maintenir une offre de logement social en centre-ville. Au contraire, les autorités locales libèrent des terrains publics en vue de leur exploitation par le capital. Ils se désengagent du logement social par la vente des maisons et appartements publics municipaux, la réduction du parc dans le cadre des opérations de partenariat public-privé, un appel croissant aux secteurs du locatif privé et à des associations à caractère philanthropique pour loger les ménages pauvres et la vente de terrains initialement destinés à la construction de logements sociaux.

Le centre-ville de Dublin est devenu le symbole de la transformation sociale en cours. À travers des politiques de gentrification, enrobées dans des discours sur la régénération, lieux et rues ont été physiquement repensés et « ré-inventés » comme des espaces de consommation pour les classes moyennes ${ }^{57}$. Le pouvoir municipal néo-libéral a recentré ses priorités, ce qui se traduit par la redistribution et la canalisation des richesses dans l'espace physique de la ville. C'est dans ce sens que l'on peut dire que le néolibéralisme s'incarne très concrètement dans les nouvelles opérations de développement urbain et que Dublin, dans ses formes urbaines, est de plus en plus représentative d'un programme néo-libéral ${ }^{58}$.

56. WARD Kevin, «Entrepreneurial urbanism, state restructuring and civilising "New" East Manchester ", in Area, n' 35 (20), 2003, p. 116-127.

57. Sмітн Neil, "New Globalism, New Urbanism: Gentrification as Global Urban Strategy ", op. cit.

58. Brenner Neil et Theodore Nik, "Cities and the geographies of "actually existing neoliberalism" ", in Antipode, no 34 (3), 2002, p. 356-386; Swyngedouw Eric, "Governance Innovation and the Citizen: The Janus Face of Governancebeyond-the-State », in Urban Studies, nº 42 (11), 2005, p. 1991-2006. 
The overall impact of land-use change, house-price increases and the loss of low-cost housing has been the social transformation and changing terms of who can use and live in the city. It is perhaps in this context that Dublin could be viewed as becoming increasingly "revanchist ${ }^{56}$ ". Working-class areas are being repackaged for middle-class consumption and, in the longer term, an attendant middle-class politics is likely to emerge in re-colonised locales, with the local grassroots agenda being set no longer by indigenous community activists and residents but by incoming middleincome residents who are more likely to act politically in a manner which increases the capital value of property rather than lobby for appropriate services and land-uses to be provided for the lower-income population.

Indeed, the recent work of Lawton ${ }^{57}$ provides evidence of growing resentment by new residents of the use by neighbouring lower-income groups of a newly-created public square (Mayor Square) in Dublin's north docks. Here the use of and access to space is being contested but the very site itself has been reproduced and gentrified. It is the site which once accommodated the community of the Sheriff Street local-authority housing complex, discussed earlier. Essentially, a low-grade residential function was upgraded and reproduced as a consumption space for the middle classes ${ }^{58}$. Fifteen years on, the new population has begun to act politically and, to use Smith's terms, in a "vengeful" or "revanchist" way, to restrict the use of the space by the original working-class population.

\section{Concluding Remarks}

Over the last two decades, urban planning in the Republic of Ireland has become increasingly infused with an ethos of entrepreneurialism with growing emphasis being placed on the facilitative role of planners rather than on their traditional reactive and essentially passive modes of operation. In Dublin, planning has been transformed in response to central-

56. Sмiтн Neil, The New Urban Frontier: Gentrification and the Revanchist City, London, Routledge, 1996.

57. Lawton Philip, “Dublin 1990-2006: 'Cultural Quarters', urban form and city boosterism", in Progress in Irish Urban Studies, n 4, 2007.

58. Zukin Sharon, Landscapes of Power, Berkeley-Los Angeles, California University Press, 1991. 
L'impact global des transformations de l'usage des sols, de l'augmentation du prix des logements et de la disparition du logement à bon marché réside dans la transformation sociale et le changement des droits d'usage et de résidence dans la ville. C'est peut-être dans ce contexte que Dublin peut être vue comme de plus en plus « revanchiste ${ }^{59}$ ». Les quartiers ouvriers ont été reconfigurés pour la consommation des couches moyennes et, à long terme, une politique propre aux couches moyennes va probablement émerger dans ces lieux recolonisés. Le programme politique local du quartier ne sera plus défini par les militants de la communauté d'origine ni par ses habitants, mais par les nouveaux arrivants des couches moyennes. Ils seront certainement plus enclins à agir politiquement pour faire augmenter la valeur de leurs biens immobiliers qu'à militer pour obtenir une amélioration des services et un meilleur usage du sol pour les populations à faibles revenus.

Ainsi, Lawton ${ }^{60}$ a récemment montré que les nouveaux arrivants protestent fortement contre l'usage que leurs voisins pauvres font d'un nouvel espace public (Mayor Square) dans les docks Nord de Dublin. Ici, ce sont les modalités d'usage et l'accès à cet espace qui font l'objet d'un conflit, mais le site lui-même, qui accueillait l'ensemble de logement social de Sheriff Street, a bien été recréé et gentrifié. Ainsi, sa fonction résidentielle (logement pour population modeste) a été revalorisée et transformée afin de constituer un espace de consommation pour les classes moyennes ${ }^{61}$. Quinze ans après, la nouvelle population a commencé à être active politiquement, et, pour utiliser les termes de Smith, d'une manière " vengeresse » ou «revanchiste », pour restreindre l'usage de l'espace par la population ouvrière d'origine.

\section{REMARQUeS CONCLUSIVES}

Les politiques urbaines menées en République d'Irlande au cours des deux dernières décennies sont de plus en plus imprégnées d'une philosophie entrepreneuriale qui donne une importance croissante au rôle facilitateur joué par les aménageurs plutôt qu'à leurs modes d'intervention traditionnels, essentiellement passifs et réactifs. À Dublin, la planification

59. Sмiтн Neil, The New Urban Frontier: Gentrification and the Revanchist City, Londres, Routledge, 1996.

60. Lawton Philip, "Dublin 1990-2006: "Cultural Quarters", urban form and city boosterism », in Progress in Irish Urban Studies, n' 4, 2007.

61. Zukin Sharon, Landscapes of Power, Berkeley-Los Angeles, California University Press, 1991. 
government urban renewal initiatives and a climate of increasing entrepreneurialism within the local authority itself ${ }^{59}$. Rather than mitigating the impacts of economic change on an already deprived inner-city community, the consequences of national and local-authority policies aimed at the regeneration of the inner city have been to increase significantly the difficulties which such communities face.

Future policies and developments, which are likely to intensify the process of gentrification and exacerbate problems of housing affordability, include the sale of local-authority owned flats and the promotion of a new cultural quarter in Dublin's Liberties area. This new initiative, which has been "imaginatively" rebranded as Dublin's SoHo (South of Heuston Station), embodies and expresses the sentiments and intentions of Dublin's new urban entrepreneurial managers with its greatest clarity yet:

[There is a] need to get the leaders of fashion into the city core to make it fashionable/desirable for the middle classes; if they come, the others will follow and suburban mind-sets will be transformed. Only then will we get the full and final revaluing of core city and all the practical results of that (better policing for example). Tony O'Reilly and others moving into Fitzwilliam Square was positive in its time. Now we have to get them into e.g. 300 sq. m. apartments in exciting schemes in the Liberties or Docklands. It happened in 18th century with move south of river by our then aristocrats. It was also successful in New York ${ }^{60}$.

Underlying such policies seems to be a pervasive arrogance of state officials, encapsulated in an interview with another DCC Senior Planner, that:

If you live in a marginalised area, one of the aspects of making it a better place to live is bringing in richer people ${ }^{61}$.

59. McGuirk Pauline and MacLaran Andrew, "Changing approaches to urban planning in an 'entrepreneurial city': the case of Dublin”, op. cit.

60. Internal memorandum, Senior Planner, DCC, quoted in Lawton Philip, "Dublin 1990-2006: 'Cultural Quarters', urban form and city boosterism”, op. cit.

61. Interview, Senior Planner, Dublin City Council, 2005. 
urbaine s'est transformée, en réponse aux initiatives de renouvellement urbain lancées par le gouvernement central, dans un climat d'entrepreneurialisme croissant à l'intérieur des autorités locales elles-mêmes ${ }^{62}$. Plutôt que d'amortir les impacts des transformations économiques sur la communauté du centre-ville déjà défavorisée, les politiques nationales et locales de renouvellement urbain du centre-ville ont contribué à grandement aggraver les difficultés de cette communauté.

Les politiques et opérations à venir vont probablement intensifier le processus de gentrification et exacerber les problèmes de logement. Il s'agit notamment de la vente des appartements appartenant à la municipalité et de la promotion d'un nouveau quartier culturel dans le secteur des Liberties. Dans le cadre d'un projet à long terme, les Liberties sont réinventées comme le SoHo de Dublin (South of Heuston Station), reflétant et exprimant avec la plus grande clarté les sentiments et intentions des nouveaux managers entrepreneuriaux urbains de Dublin:

Il faut attirer les grands noms de la mode au cœur de la ville pour le rendre "à la mode» et attractif pour les classes moyennes; s'ils viennent, les autres suivront et les mentalités «suburbaines » se transformeront. C'est seulement à ce moment-là que nous atteindrons la revalorisation complète et finale du centre dans toutes ses dimensions très concrètes (une présence accentuée de la police par exemple). L'arrivée de Tony O'Reilly ${ }^{63}$ et d'autres à Fitzwilliam Square fut positive en son temps. Maintenant, nous devons les faire venir dans des appartements de $300 \mathrm{~m}^{2}$, dans des endroits excitants, dans les Liberties ou les Docklands. Cela s'est produit au xviII ${ }^{\mathrm{e}}$ siècle quand les aristocrates ont franchi la rivière pour passer sur la rive sud. Cela a aussi été un succès à New York ${ }^{64}$.

De telles politiques se fondent sur une arrogance très répandue chez les fonctionnaires d'État, comme l'illustre bien cette déclaration d'un urbaniste en chef de la Ville de Dublin:

Si vous vivez dans un quartier marginalisé, l'un des moyens d'en faire un endroit plus agréable à vivre est d'y faire venir des gens plus riches ${ }^{65}$.

62. McGuirk Pauline et MacLaran Andrew, "Changing approaches to urban planning in an "entrepreneurial city": the case of Dublin ", op. cit.

63. Tony O'Reilly, ancien PDG de Heinz Corporation, est l'un des hommes d'affaires les plus riches d'Irlande [NDT].

64. Document interne, Senior Planner, DCC, cité par Lawton Philip, «Dublin 1990-2006: "Cultural Quarters", urban form and city boosterism ", op. cit.

65. Entretien avec un urbaniste de la Ville de Dublin, 2005. 
The processes and policies outlined above have underpinned and legitimated a process of gentrification and working-class displacement. Viewing the new entrepreneurial regime with growing alarm, one retired Chief Planning Officer has referred to this process as "social cleansing", releasing potentially valuable sites for "higher and better" uses. Thus, as Drudy and Punch cogently observe:

Indeed, it could be argued that the state is now acting as a broker for capital in this process, while co-opting dissent and assuaging workingclass combativity by diverting it into safe channels of participatory and consultative structures. Once "on the inside" of such consultative committees or boards, it is likely that many tenants and community representatives will feel less able to speak critically about any of the policies or projects, however uneasy or alarmed they might be. Moreover, these consultation processes are not as a rule subject to much external scrutiny, nor do they greatly influence the outcome beyond a few marginal concessions (for example, the appropriateness of a PPP demolition and redevelopment is never up for negotiation - minor concessions within this framework might be won or lost, but the bigger project itself is beyond challenge $)^{62}$.

Andrew MacLaran

Department of Geography, Trinity College, Dublin

Sinéad Keluy

Department of Geography, National University of Ireland, Maynooth

Paula Brudell

Department of Geography, Trinity College, Dublin

62. Drudy P. J., Punch Michael, Out of Reach: Inequalities in the Irish Housing System, Dublin, TASC at New Island, 2005. 
Les processus et politiques mis en évidence plus haut ont préparé et légitimé la gentrification et l'éviction des ouvriers. Un directeur de l'urbanisme à la retraite, qui considère le nouveau régime entrepreneurial avec une inquiétude croissante, évoque ce déplacement comme une forme de « nettoyage social » destiné à fournir des disponibilités foncières pour des usages dits «meilleurs et plus intéressants » en termes de valorisation immobilière. Ainsi, comme P. J. Drudy et Michael Punch l'ont dit de manière très convaincante:

En effet, on peut dire que les pouvoirs publics se comportent désormais dans ce processus comme des intermédiaires pour le capital, en cooptant les protestataires et en assagissant la combativité des ouvriers en les détournant vers des modes de participation sûrs et des structures consultatives. Une fois à l'intérieur de ces structures consultatives, il est probable que beaucoup de résidants et de représentants communautaires se sentiront moins à même de s'exprimer de manière critique sur les projets et les politiques, aussi mal à l'aise ou inquiets qu'ils puissent être. De plus, ces démarches de consultation ne font en général pas l'objet d'un examen extérieur minutieux, pas plus qu'elles n'influencent les résultats, au-delà de quelques concessions minimes (par exemple, l'opportunité d'une opération de démolition-reconstruction en partenariat public-privé n'est jamais soumise à la discussion - des concessions minimes à l'intérieur de ce cadre peuvent être accordées ou non mais le principe du projet en lui-même n'est pas négociable $)^{66}$.

Traduit de l'anglais par Sylvie Fol, Sonia Lehman-Frisch et Marianne Morange 



\section{Urban Vitality in San Francisco}

A T THE TURN OF THE $21^{\text {ST }}$ CENTURY, professionals and wealthy suburbanites are moving back to central cities attracted by their trendy industrial character, restaurants and clubs, art performances, or streets festivals ${ }^{1}$. Studies of inner city neighborhoods have explained economic growth and development through processes of gentrification, land value, nostalgia, or creativity, which focus on the wealthy newcomers. Instead, I propose to focus on the diverse inner city actors and their ability to create their own intense urban vitality, which became attractive to newcomers and created a major driving force of development.

The case of the Eastern Neighborhoods of San Francisco illustrates this production of vitality and recognizes the ability of inner city actors to create their own conditions of spatial justice. Until recently, the Eastern neighborhoods of San Francisco were the poorest, most marginal, and least desirable areas for investment. By the mid 2000s, they still displayed poverty, overcrowding, and drug dealing corners. But they also displayed a wealth of vibrant urban qualities. While marginal to the more traditional economic core of the city, these neighborhoods feature colorful streets and buildings bustling with small businesses producing services and goods, families raising children at community centers and parks, or artists creating new aesthetics on theaters and clubs. They offer colorful produce stores, industrial brick buildings and art workshops, restaurants with homemade-like food, clubs and theaters, and street fairs and parades. In this context, newcomers bring resources and new activities, but they are not creating new neighborhoods and a new urban vitality. Instead, they are

1. Johns Michael, "Urban Retro: The New Style in City Living", in SPUR Newsletter, San Francisco, San Francisco Planning and Urban Research Association, 2004; Zukin Sharon, The Cultures of Cities, Cambridge, Blackwell Publishers, 1995; Binnie Jon, Holloway Julian, Millington Steve and Young Craig, Cosmopolitan Urbanism, New York, Routledge, 2006. 
attracted to the existing vitality. Their arrival in many cases led not only to the displacement of low-income residents but to the destruction of the very urban vitality they were pursuing in the first place.

Confronted with the tensions between old residents and newcomers at a time of major economic transformation, the San Francisco local government unsuccessfully attempted to guide the development process and in many cases undermined the existing vitality and conditions of justice in the Eastern Neighborhoods. This failed attempt is rooted in a spatial approach that has a limited understanding of social relations, a narrow and suburban perspective of public place, and a parochial perspective oblivious of international flows. In spite of a poor planning initiatives and strong private investment pressures, Eastern Neighborhoods' actors have skillfully negotiated their place ownership and have enforced their conditions of spatial justice through intense exchanges with newcomers, developers, and local officials. This is a call for professional planners to carefully explore the vitality of the inner city neighborhoods.

The purpose of this paper is to understand the social and political tensions in the development process of the Eastern Neighborhoods in San Francisco by recognizing the urban vitality created by the local actors and the tensions that arose as newcomers and government agencies stepped into these neighborhoods. More specifically, it explores the structural blind spots in the local planning process that constrained the conditions of spatial justice.

After reviewing the social and economic trends of the Eastern Neighborhoods at the turn of the millennium, the paper focuses on the multiple development visions and spatial practices that were enacted as the City encountered increasing social tensions and political turmoil. This is followed by an assessment of the blind spots in development and planning practices. This empirical assessment is largely drawn from a participant observation approach given my role as a senior planner for the City of San Francisco. This assessment leads to a discussion of the production of spatial capital and the conditions of spatial justice as a proposal of new lenses for the planning practice.

\section{Social ANd ECONOMic Trends}

The Eastern Neighborhoods (Figure 1) are infused with populations from various countries, particularly Latin America and Asia, which grew with a recent major wave of intense international exchange of goods, infor- 


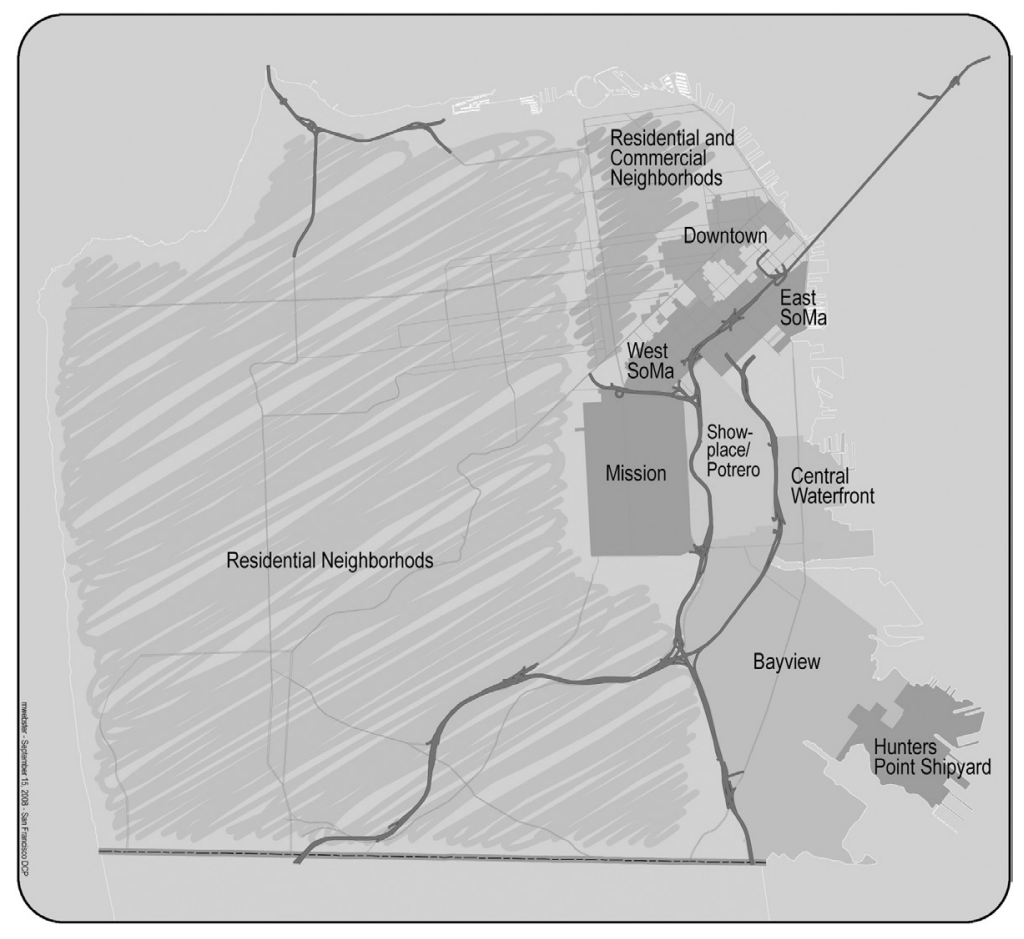

Fig. 1.San Francisco Neighborhoods: Eastern Neighborhoods, Downtown, and Residential Neighborhoods

mation, and cultural capital. They have created broad and strong networks across geographical, social, and economic boundaries providing an entry point for many immigrants, who could rapidly insert themselves into job networks, community networks, and cultural networks that ease their mobility around the city. Immigrants and their children intensify their exchanges with their homeland and express them in their everyday lives through places such as the pineapple and watermelon street cart, Chinese video shop, Chilean empanadas at Peña del Sur, Filipino breakfast joint, or Mariachis walking on the streets. These international flows have fostered multiple public cultural events, such as the Mexican Dia de Los Muertos or the Filipino Parol Lantern Festival. They have also led to the creation of a variety of ethnic restaurants and grocery stores as well as world music at the neighborhood clubs.

Left to their own devices, outside of the rules and regulations or economic pressures of the rest of the city, the Eastern Neighborhoods had the freedom to engage in a wide range of activities, from manufacturing to 
retail to housing to entertainment. Unlike homogeneous neighborhoods almost exclusively dominated by residential buildings or high-rise office buildings, businesses and residents in the Eastern Neighborhoods spread throughout pockets of industrial activities that overlapped with entertainment clusters, retail corridors, and residential areas. One could walk by the Wonder Bread factory, the bus yard, a couple of garment factories, a wholesale trade shop of Asian spices and noodles, and then stroll by auto repair shops, a cluster of graphic designers and photographers, a taqueria and a café. Then, the next block could continue with a bustling commercial street with apartments on top; a bookstore, a laundry mat, a furniture repair shop, a Chinese restaurant, a pawn shop, a pizza place, a bike shop or a used clothes shop. Right around the corner, one could step into a quiet residential alley with two, three or four flats per building, kids arriving from school and elders walking to the post office.

The Eastern Neighborhoods offered the social flexibility to accommodate gays, artists, and undocumented workers who were harassed in other places. More than many other neighborhoods in San Francisco, they accommodated populations looking for alternative lifestyles to the mainstream patterns of consumption ${ }^{2}$.

These diverse urban actors of the Eastern Neighborhoods had the flexibility to expand their social and economic networks and use their buildings and streets for a wide range of activities in the most creative ways to produce an urban vitality in their own terms. This vitality of the marginal neighborhoods has been recognized before. One could trace this trend to the "black ghettos" of the 1960s in the US, as described by Manuel Castells3: "It was in this harsh urban land left behind by the happy suburbanites, where black people congregated in their churches and where autonomous social institutions were invented ${ }^{4}$. Furthermore, Manuel Castells in his historical overview of grassroots organizing states that "... Only in the secrecy of their homes, in the complicity of their neighborhoods, in the communication of taverns, in the joy of street gatherings may they find values, ideas, projects and, finally, demands that do not conform to the dominant social interests ${ }^{53}$. At the dawn of the $21^{\text {st }}$ Century, the values, ideas, and projects of

2. Godfrey Brian, Neighborhoods in Transition: the making of San Francisco's ethnic and nonconformist communities, Berkeley, University of California Press, 1988.

3. Castells Manuel, The City and the Grassroots, Berkeley and Los Angeles, University of California Press, 1983.

4. Ibid., p. 53.

5. Ibid., p. 70. 


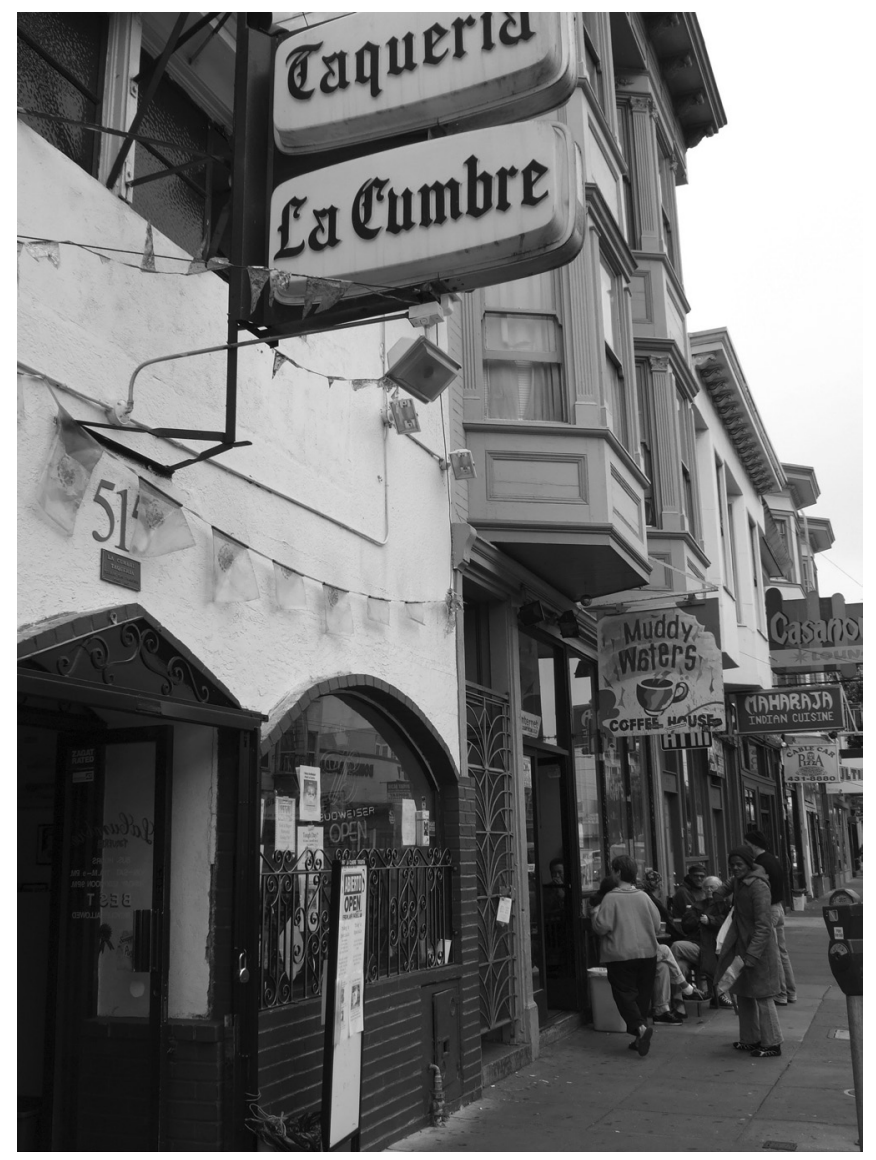

Fig. 2. Urban Vitality on Valencia Street: cafés, shops and multiple encounters (author)

the inner city population in San Francisco not only did not conform to the predominant social interests, but they became increasingly appealing to a wealthier population. In other words, the wealthier population was trying to appropriate from the marginal population the urban vitality of the inner city neighborhoods. This created a major challenge for the City given the multiple tensions that emerged as dissimilar sectors of the population struggled to produce, consume, appropriate, and transformed this vitality.

These spatial transformations in the Eastern Neighborhoods were part of broader citywide, regional, and international trends. Towards the end of the $20^{\text {th }}$ Century, San Francisco experienced major economic and social changes in its interaction with major regional and international events. San 
Francisco retained much economic vitality through its traditional financial activities, but these activities were no longer the predominant function of the city. Specialized professional services, culture, and entertainment were becoming the center of attention and much of the growth and construction were driven by them. San Francisco's core economy shifted from financial to specialized professional services with small pockets of emerging industries. In addition, the entertainment industry forcefully responded to the increasing global demands of urban consumption ${ }^{6}$.

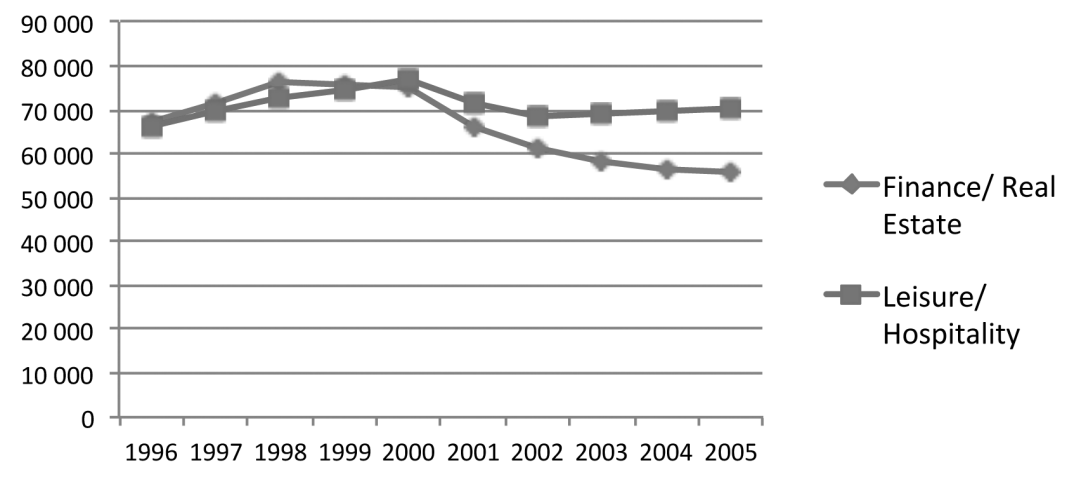

Fig 3. Finance/Real Estate and Leisure/Hospitality Jobs, 1996-2005.

Source: San Francisco Planning Department, Commerce and Industry Inventory, 2006

The strong profile in leisure and hospitality was reinforcing San Francisco's role as a central city of upscale consumption not just for tourists but for an international business elite and a wealthier resident population that demanded major housing production. Since the late 1990s, new residents arrived to remodel Victorian houses, industrial buildings transformed into live/work units, new lofts, and new high-rise buildings. Some occupied new buildings; others displaced existing renters and businesses from existing buildings. Between 2000 and 2005 San Francisco produced almost 12,000

6. Chatterton Paul, Holland Robert, Urban Nightscapes: Youth Cultures, Pleasure Spaces and Corporate Power, London, Routledge, 2003; Binnie Jon, Holloway Julian, Millington Steve, Young Craig, Cosmopolitan Urbanism, New York, Routledge, 2006; O'Connor Justin, Wynne D, "Left loafing: city cultures and postmodern lifestyles", in From the Margins to the Centre: Cultural Production and Consumption in the Post-Industrial City, O'Connor Justin, Wynne Arena, Aldersнот Hants (dir.), 1996, p. 49-89; Bell David, “The Hospitable City: Social Relations in Commercial Spaces", in Progress in Human Geography, no 31 (1), 2007, p. 7-22. 
housing units and approved construction of 16,500 housing units 7 . More than one third of those 12,000 units were built immediately adjacent to the financial core, in the Eastern Neighborhoods. In addition, the northern areas of the Eastern Neighborhoods experienced higher increases in housing cost than any other neighborhoods in the city, and much higher than California or the US ${ }^{8}$. This new wave of housing production in and around downtown was not unique to San Francisco; Eugene Birch ${ }^{9}$ and Robert Beauregard ${ }^{10}$ have documented similar patterns throughout major US cities. In addition, over the last two decades, the growth of housing production contrasts with the decline in office production (Figure 2), which further illustrates the shift in the local economy priorities from finance towards consumption of urban amenities.

But most dramatic was the decline in population during a period of major housing production. Between 2000 and 2005, San Francisco lost 35,700 people $^{11}$. Furthermore, this decline in population was happening after 20 years of constant population growth.

\section{Changes in Housing and Population $2000-2005$}

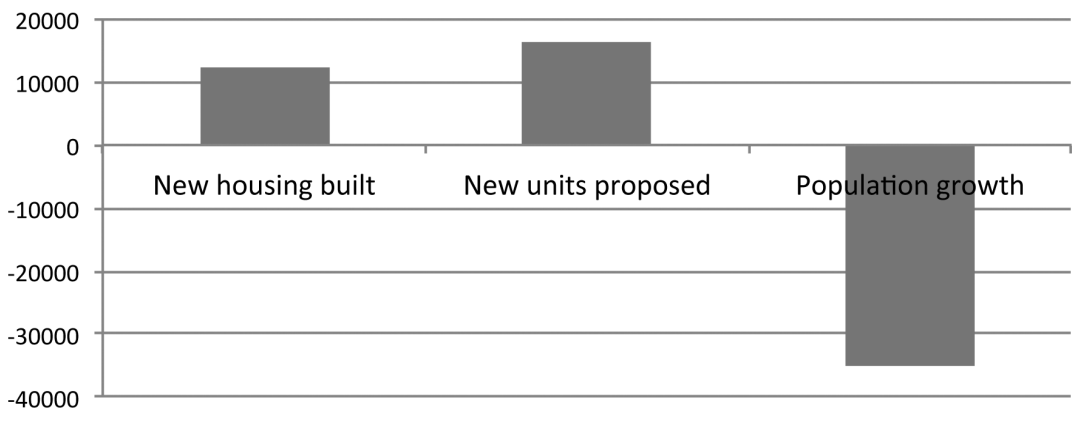

Fig. 4. Changes in Housing and Population, 2000-2005. Source: San Francisco Planning Department, Housing Inventory, 2006, US Census

7. San Francisco Planning Department, Housing Inventory, 2008.

8. San Francisco Planning Department, Unpublished economic and land use data, 2007; Zillow, http://www.zillow.com, entered October 30, 2007.

9. BIRCH Eugene, "Having a Longer View on Downtown Living", in Journal of the American Planning Association, $\mathrm{n}^{\circ} 68$ (1), 2002, p. 5-21.

10. Beauregard Robert, "The Textures of Property Markets: Downtown Housing and Office Conversions in New York City", in Urban Studies, vol. 42, $\mathrm{n}^{\circ} 13$, 2005, p. 2431-2445.

11. US Census Bureau, American Community Survey, Multi-year profile of San Francisco, 2007. 
This population change included an increase in the share of White and Asian population, and a decline in all other ethnic groups ${ }^{12}$, which reveals not only a change in density but the ethnic displacement. San Francisco was the only major city in the US that showed a decline in Latino popula$\operatorname{tion}^{13}$. In summary, these demographic and housing production trends document the departure of many Latino, African-American, and Filipino families and the arrival of a wealthier, predominantly White population of singles, or couples with no children, who use more space per person. This strong demographic shift had an impact on the ethnic and cultural diversity of the city and the vitality of the Eastern Neighborhoods in particular.

These changes in industries, housing production, and social composition of the city triggered major spatial tensions in the Eastern Neighborhoods. Too much money had arrived too fast in San Francisco and created much conflict. Dot-com companies were created overnight by a few young professionals coming together with good intentions but not much business experience or understanding of the neighborhood. This was followed by live/work and high-rise apartment buildings. The problem was not the arrival of money per se but the shape, form, and speed at which it arrived. It caught the City completely unprepared to guide its arrival. Displacement of individual families, businesses, and artists was a major problem, but this issue was amplified by the disruption of clusters of activities, social and economic networks, and neighborhood character. The displacement of the residents was not just a social loss but a loss of the urban vitality valued by a broad constituency.

\section{Visions of The City}

At the turn of the millennium, the high level of social tension and political conflict afforded the city an opportunity to openly question its path of development. The major demonstrations and even acts of violence were important for the marginal communities to gain visibility in the politics of the city. But even more transcendental was the ability of community organizations to engage their very diverse populations with the local planning process; a process that moved from extremely technical and bureaucratic procedures to a debate of spatial justice.

Professionals and new residents appreciated the trendy industrial feeling of South of Market, very close to the financial district, to shops at Union

12. Ibid.

13. Ibid. 
Square, and to convention facilities and entertainment at Yerba Buena Center. High-tech engineers from Silicon Valley also realized that they could move to San Francisco without spending more in housing but with more access to better restaurants and night life. Live/work units, originally intended for artists, were very appealing to the new generation of professionals seeking an alternative to suburban housing.

The Eastern Neighborhoods experienced a major political turmoil as these incoming young professionals and new development displaced many families, small businesses, and artists. A major dance performance blocked the street to complain about the displacement of a dance studio by a new upscale housing project. Community organizers demonstrated in front of a landlord's business who evicted a Latino family. Community activists marched within the planning department offices with drums and whistles until they got arrested. Hundreds of residents and workers arrived to a community meeting with municipal authorities. Huge billboards appeared over night mocking the arrogant attitude of the new wealthy residents in the neighborhood. Youth threw eggs at SUVs, slashed tires of luxury cars, and inscribed "yuppies go home" in colorful graffiti. A strong coalition of residents, workers, artists, and community organizers came together and challenge the strong pressures of displacement. This is how the community planning process of the Eastern neighborhoods began.

While slow and limited, in 2002 the City government responded to the political outburst with the Eastern Neighborhoods community planning process that promised a rezoning of the area and the development of community plans. The City had already started a rezoning effort in 1997, but it was unable to create a viable proposal that could be adopted in a very tense political climate at that time. The community planning process covered almost a quarter of the total land in the city and served multiple purposes.

The formal City planning process was shaped by multiple dominant visions that drove the development process and defined the conditions of justice. These visions provide an understanding of the social and economic expectations of the dominant stakeholders in the city. Some of them were formally adopted within the government planning process, while others were more quietly enacted through benign policies and private investments.

\section{A vision of highest and best use}

The concept of highest and best use comes from real estate appraisals but has been adopted by planning practices, as the urban planning field 
increased its concern with profit maximizing. This vision focuses on economic growth rather than social justice. Still, when confronted with the issue of justice, proponents of this vision argue that a growth of resources can benefit the city as a whole including the most economically disadvantage population.

While in the 1980s office use was considered the highest and best use for San Francisco, the late 1990s and 2000s were centered on housing. The construction of housing in industrial land and inner city neighborhoods was delivering the highest levels of profit, as the demand for city living increased. This argument was also substantiated as a response to the housing "crisis" in San Francisco, the Bay Area, and California. Profit and productivity was supporting the provision of housing for a growing population, which was primarily a middle and upper income group. The housing crisis became a popular framework to justify the production of any type of housing buildings and displacement of any tenants. In addition, regional authorities pursued jobs-housing balance, meaning the ability of each city to house all its workers, as a solution to the increasing transportation problems in the region. As a result many industrial buildings were demolished to build housing projects under the rationality that the retention of a few jobs could not compete with the opportunity of housing several households. This is a clear vision of developers and property owners; their job is to generate profit and maximize the economic value of land in the very short term.

This vision leads to a process of gentrification in which upscale housing and entertainment assumes a priority over industrial businesses, art studios, or low-income housing. While many city officials acknowledged the contributions of existing activities, they joined developers and new residents to argue that industrial businesses needed to be relocated outside of the city because they were using very expensive land that could be dedicated to lofts or high-rise buildings, as the highest and best uses.

\section{A vision of a creative city}

The vision of a creative city and creative class, as proposed by Richard Florida ${ }^{14}$ and Charles Landry ${ }^{15}$, emphasized the role of innovation and creativity as engines of economic growth in cities today, particularly in rela-

14. Florida Richard, Rise of the Creative Class: And How It's Transforming Work, Leisure, Community and Everyday Life, New York, Basic Books, 2002.

15. Landry Charles, The Creative City, London, Earthscan Publications Ltd., 2000. 
tionship to a middle and upper professional class and their consumption demands. This became a very popular strategy across cities of all sizes and across the world. San Francisco was considered by these and other scholars as a city of much creativity. Most government authorities and residents agreed with the innovative and artistic qualities of the city and were willing to support them, at least some of them. Along those lines, City legislation and special initiatives were developed on biotechnology, green industries, arts promotion, and tourism. The multimedia industry in San Francisco was an exemplary case of innovation emerging on the urban edges and significantly contributing to the high technology and informational economy. While San Francisco never embraced this vision officially, the City paid close attention to the desires of the professional workforce in the region and the international elite to move to the city. This was another vision where the concept of justice was not addressed. The central focus was on consumption of urban entertainment by a wealthy population. However, in some cases, conditions of justice were framed by the tensions between traditional professional activities and emerging industries and arts.

\section{A vision of smart growth}

The "smart growth" vision was probably one of the most popular approaches explicitly adopted by the municipal planning process and the one embraced by multiple constituencies. This vision suggests concentration of housing in city centers to make better use of existing infrastructure, support public transportation rather than automobile use, and sustainable development ${ }^{16}$.

The beautification of the city and the re-crafting of neighborhoods for the new residents were strongly supported with master plans, policies, and a robust budget. The "smart growth" approach was contrary to the clean slate style of previous redevelopment efforts. "Smart growth" initiatives in San Francisco included the construction of small pockets of housing in close proximity to cafes, bookstores, antique furniture stores, and upscale restaurants. One of the most important planning initiatives was the Better Neighborhoods program, launched in 2000 with a couple of million dollars for consultant services. Later in 2005, the Better Streets program, a

16. Calthorpe Peter, The Next American Metropolis: Ecology, Community, and the American Dream, New York, Princeton Architectural Press, 2003; DuAny Andres, Plater-Zyberk Elizabeth, Speck Jeff, Suburban Nation: The Rise of Sprawl and the Decline of the American Dream, New York, North Point Press, 2000; Greenbelt Alliance, Smart Infill, San Francisco, Greenbelt Alliance, 2002. 
street improvement program with an initial budget of 27 million dollars, was one of the most important mayor's efforts to make the streets nicer and greener. These were truly exemplary planning efforts breaking new ground in terms of urban design, public transit, and high density housing. It took much effort to adopt new concepts, which required less automobile use. At the same time, these efforts illustrate the emphasis of the physical planning approach, neglecting the social and economic dimensions. The Better Neighborhoods efforts catered primarily to an upper-middle class, and in some cases at the expense of the working class population and small businesses. As one Filipino resident stated, "I am too brown for the greens." The smart growth vision was the most prominent vision adopted by the City and translated into a wealth of resources for plans and projects in contrast with the lack of funding for the Eastern Neighborhoods.

\section{A vision of a global city}

Since the last quarter of the last century, the idea of a global city has been discussed by many scholars as a place of advanced technology, information and knowledge production, and high connectivity with other places ${ }^{17}$. In the global urban hierarchy, San Francisco has never been at the top with New York, Tokyo, or London; its size, its economy, its cultural events, and its resources have always been of a much smaller scale. Still, San Francisco has always had an intense international engagement through selected professional services, tourism, and has been a major gateway for recent immigrants working in the service sector. Some City efforts have supported new industrial strategies but most resources were invested in entertainment and cultural facilities such as the stadium, convention facilities, and historic buildings, among others. Luxury apartments for short-term city visits were also another major element of attraction for international visitors. The vision of a global city was embraced by developers, businesses and city officials in its technological and industrial dimensions, but it was most suc-

17. Sassen Saskia, The Global City: New York, London, Tokyo, Princeton (NJ), Princeton University Press, 1991; Castells Manuel, The Rise of the Network Society, Cambridge (MA), Blackwell, 1996; Hall Peter, Cities in Civilization, London, Phoenix, Orion Books Ltd, 1999; Sмітн Michael P., Transnational Urbanism, Locating Globalization, Massachusetts and Oxford, Blackwell Publishers, 2000; IrAzABAL Clara, City Making and Urban Governance in the Americas, Curitiba and Portland, Burlington, Ashgate Publishing Limited, 2005; Massey Doreen, For Space, London, Thousand Oaks, California, SAGE, 2005; Chion Miriam, Global Links and Spatial Transformation in Metropolitan Regions, Lima in the 1990s, Doctoral Dissertation, Department of City and Regional Planning, University of California, Berkeley, 2000. 
cessful advancing San Francisco's role as a major hub of consumption for a global professional elite. An alternative global city was also developed on the opposite side of the class spectrum. Low-income immigrants, artists, and small businesses have rapidly expanded their mobility of money, goods, and people as well as created dense networks of cultural and knowledge exchange. A comprehensive approach to the global city vision provides a useful platform to explore negotiation of spatial justice by multiple mobile actors.

\section{A vision of urban retro}

While the smart growth vision was the most explicitly embraced in the planning process of the city, the urban retro vision proposed by Michael Johns ${ }^{18}$ had probably a stronger presence but it was never adopted in the official planning or local government language. Michael Johns argued that cities are experiencing a trend of urban retro, "a growing nostalgia for the tradition and excitement of urban life" and an "attempt to instill history and authenticity into the city's streets, buildings, and neighborhoods." And no other city displays a better urban retro effort than San Francisco. Thus, for Michael Johns, new residents and planners want to recreate a city that existed in other times with old fashioned lamps, vintage trolleys, industrial brick facades, but without the continuity and identity of the real neighborhoods from the 50s. In the urban retro gentrified neighborhoods 90 percent of the people are white and most of them highly educated; they lack the diversity that new residents claim to like about the city. "For real diversity in these neighborhoods, you have to look to the dogs. These neighborhoods tend to have more types of dogs than classes of people..." remarks Johns.

Under this vision of urban retro, we could argue that the task of planners becomes the proper crafting of images undisturbed by the complexities of urban space and spatial justice. New residents want the industrial charm but without the sounds of auto repair shops or band rehearsal studios, the smells of breweries or sausage factories, or movements of trucks. Sitting on a sidewalk café cannot be spoiled by the presence of homeless or repair shops' fumes. A loft in a renovated industrial building retains the brick walls and high ceilings but with completely remodeled plumbing, new bathroom and kitchen fixtures, and only quiet residential neighbors. Now, these are not just images or empty forms, the goal is to make the city look old, but with the peace and quiet of a suburb. Michael Johns argues that

18. Johns Michael, "Urban Retro: The New Style in City Living”, op. cit. 
those forms are animated by a suburban culture that is expanding in San Francisco:

... a stage-set assembled from miscellaneous pieces of the past and from new pieces made to look like they are from the past... [U]rban retro tries to look old while being new, strives for urbanity in suburban ways, wants authenticity in novel settings, and yearns for diversity and uniqueness in relatively homogeneous communities replicated in city after city.

The development priorities focused on economic growth, natural and built environment, and upscale consumption led to visions of the city detached from social disparities and justice. In contrast, the global city and urban retro visions, focused on international mobility and historical references, have acknowledged the economic disparities and social and political challenges in the construction of a just city.

These visions were overlapping and clashing given the political differences across local government agencies. By 2000, San Franciscans had elected a progressive Board of Supervisors that counterbalanced the prodevelopers approach of Mayor Willie Brown. At the very broad level, the Board of Supervisors was more concerned with social issues and needs and the mayor's office was more concerned with the construction of new projects. Political differences were also embedded within City agencies; the Planning Department had an administration predominantly concerned with approval of projects and responsible for securing good and stable relationships between developers and the mayor's office while many mid-level planners were concerned with issues of displacement and developed close relationships with community organizations. The Board of Supervisors was very engaged in the tensions of the Eastern Neighborhoods development process and placed political pessure to support this effort. However, they had limited control over allocation of resources. The mayor and the Planning Department administration allocated very limited resources to this effort; a few planners were assigned but without a budget for consultants or production. Thus, the political and economic tensions within the City were an additional constraint to the narrow planning process mostly concerned with the physical qualities of the city.

The economic recession of 2000 minimized the sprawling of chaos and social tensions, since construction and investments had slowed down. But, in spite of the recession, and as the city recovered from it, development continued to be guided by a few fragmented pieces of legislation. By the end of 2008, after much displacement of neighborhood fragmentation, the 
City approved the community plans. It remains to be seen the impact of their implementation.

Community leaders led intense and sophisticated grassroots organizing to push the planning process towards a broader exchange of social concerns. In addition, careful coordination between community organizers and midlevel planners allowed the insertion of some of those social concerns into the planning process. Community organizations, mid-level city planners, and Members of the City's Board of Supervisors inserted a socio-economic study and a public benefit zoning proposal into the planning effort. The socio-economic study addressed social and economic impacts of recent investments and was inserted in the environmental review process, the strongest legal tool in the entire planning process. The public benefit zoning proposal addressed redistribution of profit in the community and was inserted in the rezoning efforts and plans throughout the city, beyond the Eastern Neighborhoods. These efforts were outside of San Francisco's traditional planning process.

The developers, small and large, also engaged in alternative negotiations. Thus, the battle was shifting from demonstrations on the streets and hearings at City Hall to direct negotiations among city officials, community representatives, and developers that took the development process beyond the boundaries of the formal planning process.

\section{ENCOUNTERING INVISIBILITIES AMONG THE VISIONS}

The City of San Francisco regulates the use of plastic or metal forks at restaurants, it creates public patios inside and on top of buildings that can only be accessed by those able to recognize a cryptic sign, it designs public benches that prevent homeless people from resting and sleeping there, it prohibits additional units for family in-laws but allows them for servants. The complex rules that regulate the production of space in San Francisco (through more than ten pounds of zoning codes) had been created to address specific goals, such as limit the number of fast food outlets, provide some open space for office workers, eliminate the homeless population, or accommodate wealthy families. They have addressed specific cultural and social relations, but they have been hidden. Thus, the planning practices can be elaborated in their specific social goals but they were framed by a rigid professional language, narrow understanding of urban vitality, and limited considerations of conditions of justice. 
Once I had a conversation with a high official at the Planning Department about the emphasis on physical structures as a way to hide the social dimension of development. His response clearly conveyed the constraints of the planning practice today. He said "I can predict how many cars will cross the street in front of the project, but I cannot predict the color of people ${ }^{19}$. How can the City ignore the fact that a new project with apartment's prices ranging from $\$ 650,000$ to 1.2 million, and up to 70 percent pieds à terre, will very likely be occupied primarily by a wealthy white population? The people that can access these pieds à terre properties have a very well defined profile in terms of income, ethnicity, and job. It represents 5 percent of the existing population in San Francisco. This was street knowledge, but this knowledge was not part of the transportation and environmental review models ${ }^{20}$. This was not part of the planning process. Here, we encounter an explicit structural constrain in the definition of space in which spatial practices, common knowledge, and everyday life experiences are excluded from the planning process. The idea of a just city was not part of the planning inquiry or planning process.

In 2004, I attended an environmental review meeting in which a group of Latino residents came to talk to the planners about the rats in their homes, the lack of space for kids to play, and the limited access to health services. These planners could not understand much of what these people were saying, in spite of the simultaneous translation from Spanish to English. Because most of their interactions are with consultants, planners could read regression models, vehicle counts, or read zoning legislation, but cannot connect the quality of the environment to the living conditions of these people.

Granted, we could argue that the environmental review process in San Francisco has become a monster: the strongest legal mandate turn into a very expensive and time consuming process that produces no insightful knowledge or any better understanding of the development process across parties. But even if we look at one of the highest profile plans, The Market and Octavia Better Neighborhood Plan, we can see the absence of people and social dimensions. This plan received much financial and political support from the City and various constituencies. It exemplifies how the city embraced the smart growth vision as a new way of guiding development

19. Planning Official, Planning official meeting with author, San Francisco, October 14, 2006.

20. Corburn Jason, Street Science, Community Knowledge and Environmental Health Justice, Cambridge, MIT Press, 2005. 
and housing production. Most of the 200 pages were dedicated to the design of buildings, streets, and landscapes. Only 11 pages were dedicated to the housing section, which was the closest section to any social or economic reference but without any mention of current or new residents. The text below illustrates how the benefits of development were addressed in terms of physical shapes: scales, density, and fine-grained fabric. Furthermore, it explicitly "defers" any issue of affordability or homelessness to the larger city structure.

This plan encourages housing as a beneficial form of infill development-new buildings at traditional scales and densities, reflecting the fine-grained fabric of the place. In many respects, this plan does not diverge from established and continually evolving citywide policies and programs of housing affordability. It does not establish new inclusionary standards, new funding mechanisms, nor create its own solutions to homelessness in the city. On these matters, which cannot be affected on an area-by-area basis, the plan defers to the larger citywide structure $^{21}$.

By fragmenting the tasks and geography, the City was producing more isolated, quasi suburban enclaves rather than contributing to the conditions of social justice, to the rich cultural and social fabric of the city, or to the production of urban vitality. This is not to portray an evil or unprofessional profile of planners in San Francisco. They are very smart and caring; they carried progressive politics credentials, and are socially sensitive. They are also very knowledgeable; they come from the best planning schools in the country. They prepare comprehensive plans and compile housing and economic data to inform plans and policies. They develop many transportation models to predict congestion and parking and 3-D simulation models. They go into infinite details in the production of many pounds of zoning regulations to determine if a restaurant can use a tablecloth or not. Plans include very sophisticated urban design guidelines, which defined the perfect sidewalk and bench widths, innovative shapes for urban parks, precise proportions for slender high-rise towers, or intricate building shapes to maximize sunlight. All of these elements have dramatically enhanced the quality of city life. But... for whom?

How can planners define their job as the regulation of land and physical planning detached from their social and economic dimension ${ }^{22}$ ? Why do

21. San Francisco Planning Department, Market and Octavia Neighborhood Plan, City of San Francisco, 2002.

22. San Francisco Planning Department, Junior and senior planners meeting with author, 2006. 
planners avoid the social dimension of the city? I argue that this invisibility of the social realities of the Eastern Neighborhoods explain the constraints of the planning process. The social dimension was invisible and hidden but not absent.

Some of these invisibilities were skillfully addressed by one of the community initiatives, the Mission Anti-displacement Coalition (MAC), which managed to align very diverse community organizations "to stop the displacement of working class people in the Mission District and San Francisco ${ }^{23}$." They directly addressed conditions of justice through the People's Plan, which focused on two main strategies: "democratizing the planning process and challenging inappropriate development projects in the Mission District ${ }^{24}$." While MAC gathered multiple community and art organizations, the core organizational members included St. Peter's Housing Committee, People Organizing to Defend Economic and Environmental Rights (PODER), Mission Economic Development Association (MEDA), Central American Resource Network (CARECEN), and Dolores Street Community Services (DSCS). These organizations relied on their own funding coming from public and private sources.

MAC was able to bring to the table the social construction of space and its networks. MAC's activities ranged from demonstrations on the streets to a grassroots educational program on land use, to an international conference. They recognized that demonstrating to fight evictions was acting too late in the development process and decided to engage with the planning process in the definition of land uses. Bringing families, workers, and recent immigrants to participate in the planning process was not an easy task, given the technicality of the language which was barely understood even by planning professionals, but they were successful. Eric Quezada, the leader of MAC, was ready to act on the immediate needs of the community, finding a bed for a homeless person or requesting a loan from the Mayor's office, but only because these actions were connected to a broader and future social change ${ }^{25}$. This connection between present actions and future vision were much weaker among planning professionals. While planners were reading and attending local conferences to revise the zoning codes, MAC activists were traveling to Latin America to train affordable housing government agencies and having international dialogues at the Global Social Forum. MAC representatives not only had a direct engagement in

23. Mission Anti-displacement Coalition, http://mac-sf.org/index.html, 2006.

24. Ibid.

25. Quezada Eric, Community Organizer, Interview with author, October 2005. 
the production of space in its social dimensions and fluid international networks, they also had a much broader perspective on development and planning practices.

MAC's direct engagement to shape the planning process was imbued with much tension even when city agencies were eager and open to develop a joined effort. Exchanges between the planning department and community organizations were very tense and it took time and effort to open discussions. Planners were yelled to go home and accused of pushing the African-American community out of the city at the multiple initial meetings in the Eastern Neighborhoods community planning efforts. Still, the level of interaction between planners and marginal communities matured and became sophisticated at times. Low-budget restaurants provided food for the City workshops because the City had not allocated any resources. Community activists brought and trained in advanced more than 300 participants to City workshops, ran small bilingual workshops for immigrants, built leadership among youth, and crafted sophisticated strategies to negotiate with government officials. Planners stayed past midnight cleaning the rooms used for the community workshops, way beyond their duties. Some planners were even informed in advance about the political demonstrations and takeovers of City buildings organized by community activists. The combination of grassroots mobilization, engagement with planning professionals and local officials, and community leadership for social change pushed the planning process to address conditions of spatial justice in the Eastern Neighborhoods.

\section{Production of SPATIAL CAPITAL \\ AND CONDITIONS OF SPATIAL JUSTICE}

Urban development policies include some people, some activities, and some networks and exclude others. In San Francisco, most planning resources and much of the new development were catered to a professional, high-income, primarily white population. (High-rise residential development in Rincon Hill and Transbay area, infill "smart growth" development in Market-Octavia Better Neighborhood, live-work buildings throughout the Eastern Neighborhoods, etc.) Cities are constantly changing and the City of San Francisco might be purposefully pursuing a vision of the city of upscale residential buildings and entertainment, at the expense of lowincome housing and small shops and industries. It might be pursuing a shift from an urban to a suburban culture; from a diversified place of production to a homogeneous place of consumption. The high-rise residential 
towers illustrate the suburban trends in San Francisco. These towers house their own gyms, SUV parking, and grocery stores. People can use valet parking to go to theaters and restaurants without the inconvenience of ever walking on the streets. People can look at the city's skyline from their windows; get to the baseball game in a few minutes; or access a wide range of food while enjoying the privacy and comfort of their homes.

If the City were to pursue this vision, then, the planning process might be required to minimize or make invisible those people, activities, and places that are outside of this vision. But, here I argue that this vision presents some inherent contradictions because the City might be dismantling the urban vitality of the inner city that the new residents were pursuing. The City might be losing the vitality that made San Francisco very attractive in the first place. The City might be undermining the spatial capital of the inner city. We could also approach the construction of this suburban-like space as a work in progress; we could acknowledge the efforts by new residents and planners to align those physical elements with a new suburban sensibility in the city, a major development trend identified by Johns. New residents might be creating a new spatial capital of their own, but as Johns suggests, quoting Henry James, this could be a process that takes "....an endless amount of history."

The urban retro vision highlights a development approach with an emphasis on the development of physical elements without much history or social meaning behind, except for a feeling of nostalgia. This vision highlights the absence of spatial capital in the several recently refurbished urban retro neighborhoods. The physical elements such as signs, brick walls, and vintage lamps are disconnected from their original activities and networks that made the spatial capital of the 1950s. I find Michael Johns' studies $^{26}$ of the city glamour of the 1950s extremely elaborate in its empiri$\mathrm{cal}$ and analytical constructs and very insightful to inform the recent development trends in San Francisco. However, I propose that we do not have to time-travel as far back as the 1950s to observe fine urban qualities; we can find those in the inner city neighborhoods of San Francisco today. We can recognize the value of the margins, the spatial capital of the margins that has become so attractive to presumably bored suburbanites. Johns and many others assumed that after the 1950s "cities fell into a long period of physical and cultural decay... [and that renewal projects failed to improve

26. Johns Michael, Moment of Grace: The American City in the 1950s, Berkeley, University of California Press, 2003; Johns Michael, "Urban Retro: The New Style in City Living", op. cit. 
them]." I argue that this is a well defined but narrow bourgeois perspective. If we were to look carefully we would realize that while renewal projects failed and while developers and planners were mostly concerned with office towers and suburban housing, much was happening in the inner cities during the second half of the $20^{\text {th }}$ century. We do not have to go the 1950s to encounter neighborhoods in which the community can get together and build a park for children to play, to walk to the corner taqueria and have a beer and tacos with a few friends, or to go to a house turned into a cultural center for local musicians and poets. This is the spatial capital that the inner city has been quietly producing while everybody else has been concerned with other higher profile places. These were the conditions of spatial justice produced at the margins of major urban development trends. The spatial capital is produced by urban actors when their activities and their networks intensify the coherent use of the physical setting. I propose the concept of spatial capital to recognize the production of urban vitality by marginal actors and their negotiation of spatial justice.

The city has been struggling to redefine its conditions of urbanity. Industrial changes, construction investments, consumption patterns and demographic trends placed the spotlight of development on the Eastern Neighborhoods, their spatial capital and attractiveness to other populations. At the same time this spotlight challenged the production and reproduction of this spatial capital, as newcomers, developers and city officials ignored the conditions of production.

The City was ill equipped to engage in the development and planning process of the Eastern Neighborhoods. More specifically, planners did not know how to engage with the spatial qualities of the inner city neighborhoods. They played with designs, forms, and images detached from their social dimensions and tensions. And, even when they attempted to explore the social complexities in an interaction with marginal communities the planning process was very limited and fragmented at best. The limited engagement of the City in the production of spatial capital led to a polarized situation in which two competing visions driven by the major stakeholders were constantly in tension; one that pursued an ethnically and economically diverse working class place and the other that pursued an upscale residential place with entertainment.

The diverse urban actors in the Eastern Neighborhoods, immigrants, workers, artists, and small businesses, produced a major spatial capital: streets and public places of intense economic, social, and cultural activities in which social tensions were openly addressed and international exchanges were expanded and deepened. However the arrival of wealthier newcomers 
was undermining the production of this spatial capital, intentionally and unintentionally. Facing these spatial tensions, the City was unable to articulate a development and planning process to address the conditions of spatial justice. This failure was rooted in a narrow vision of space framed by the shapes and forms of physical objects detached or hidden from its social relations and tensions and from its expanding international networks. Not that the spatial capital or the conditions of spatial justice will easily disappear even if the City wanted to dismantle it. In spite of the strong wave of displacement, much of the spatial capital, many Latino and Filipino families, shops and studios, taquerias and pho houses remained in the city by 2008. The resilience and organization of these diverse Eastern Neighborhoods actors complicate the development process of San Francisco; the land was not empty for new construction.

The challenges of development trends in central cities like San Francisco in the $21^{\text {st }}$ century demand a serious revision of the planning practice in which an understanding of the production of spatial capital in its physical, social and networks dimensions is acknowledged and in which the conditions of spatial justice are reconsidered by local governments. Without these spatial considerations planners and local governments become irrelevant in the development process.

Miriam CHion

Association of Bay Area Governments, Oakland 
ESPACES PUBLICS

ET EXCLUSION SPATIALE 

Public Space and the Politics

of Propinquity in Johannesburg

Espace public et politique de proximité à Johannesburg 


\title{
Public Space and the Politics of Propinquity in Johannesburg
}

\begin{abstract}
Few WeEks AGo I took a friend into the inner city to show her the $A$ changes that had been taking place over the past few years. We 1 entered Gandhi Square and as I showed her the memorial stature of Gandhi at the height of his legal career in South Africa, we noticed that a young middle-class man, clearly an office worker, was being chased off a circular bollard where he had sat for a brief rest before his bus arrived.
\end{abstract}

Later, my friend and I sat on a square ventilation shaft with a piece of marble on it. No sooner had we sat down than the same city security guard - or "street ambassador" - called over what appeared to be her supervisor to tell us to move.

"Why?" I asked.

"Because", he said, "there was an incident last week and the thing you are sitting on blew up."

"Blew up!" I said, genuinely astonished by the explanation, "but it looks like a ventilation shaft for the parking below."

Noting my scepticism, the security man changed his tack. "But criminals sit here and watch and so it's not safe."

As we continued with our discussion, my friend noticed that schoolchildren were being chased from the square. She asked our "street ambassador" what was going on. 


\section{Espace public et politique de proximité à Johannesburg}

I L Y A PLUSIEURS SEMAINES, j'ai emmené une amie faire un tour en centre-ville pour lui montrer les changements qui s'y étaient produits depuis quelques années. Nous sommes allées à Gandhi Square et je lui ai montré la statue qui a été érigée pour célébrer la mémoire du célèbre avocat indien; il est représenté ici au moment où sa carrière d'avocat en Afrique du Sud était à son sommet. C'est alors que nous avons vu un jeune homme de la classe moyenne, travaillant manifestement dans le secteur tertiaire, se faire chasser par un garde d'une borne où il s'était assis pour un court moment de repos en attendant son autobus.

Plus tard, mon amie et moi-même nous sommes assises sur un conduit d'aération carré dont la partie supérieure était en marbre. Nous venions tout juste de nous asseoir que ce même officier de sécurité municipal - ou « ambassadeur des rues » comme on les nomme à Johannesburg - a appelé une personne, qui s'avéra être son supérieur hiérarchique, pour nous demander de circuler.

«Pourquoi? demandai-je.

- Parce que, répondit-il, il y a eu un incident la semaine dernière et la chose sur laquelle vous êtes assises a sauté.

- Sauté! dis-je, très étonnée par cette explication, mais on dirait un conduit d'aération pour le parking qui est en dessous. »

Remarquant mon scepticisme, le garde de sécurité changea de tactique. «Oui mais les criminels s'assoient ici et vous guettent, et donc c'est dangereux.»

Alors que nous continuions de discuter, mon amie remarqua que des enfants étaient en train de se faire chasser de la place. Elle demanda à notre « ambassadeur des rues » ce qui se passait. 
"Oh, because they are supposed to be in school and the Department of Education told us that there can't be schoolchildren here because they have to go to school," he responded.

"But this is a public space..." I trailed off, realising that I was never going to win the point. "Who can I speak to about this?"

The guard brightened, "Oh, you can speak to the man who owns this space," and proceeded to give me the name of a businessman.

And so we left Gandhi Square, where people perched uncomfortably on bars waiting for their buses under Gandhi's lofty gaze, and went to have a latte at a trendy café around the corner.

\section{Public SPACE AND The “GOOD” CITy}

For urban specialists, public space has a special significance in the city. From the agora of ancient Greece and the political functioning of the Forum Romanum, public space has always been viewed as having some relationship with the public sphere; as being an expression of urban governance and the everyday politics of urban public life ${ }^{1}$. Public spaces are where a range of political identities can be expressed. “... The myriad boltholes that are to be found in cities provide some possibility to the millions of dispossessed, dislocated and illegal people stripped of citizenship to acquire some political capital2".

Public space reflects the relationship the city has to its inhabitants (citadin). The urban poor have limited access to paid-for urban leisure spaces, and frequently their residential spaces are inadequate. Traditionally, public spaces are also where the economically marginalised ensure some kind of a livelihood. In developing economies, this frequently takes the form of hawking in public areas, begging in the street, and so forth. Drawing on Henri

1. Canniffe, Eamonn, Urban Ethic. Design in the Contemporary City, Oxon, Routledge, 2006.

2. Amin Ash, "The Good City", in Urban Studies, no 43 (5), p. 1012, mai 2006. 
«Oh, c'est parce qu'ils sont censés être à l'école et le Ministère de l'Éducation nous a fait comprendre qu'il ne peut y avoir d'élèves ici parce qu'ils doivent aller à l'école, répondit-il.

- Mais c'est un espace public ici..., interrompis-je, réalisant que je n'aurais jamais raison dans cette discussion. À qui puis-je rapporter ce problème? »

Le visage du garde s'est illuminé tandis qu'il me répondait: «Oh, vous pouvez parler à l'homme à qui cet espace appartient ", et il m’a donné le nom d'un homme d'affaires.

C'est ainsi que nous avons quitté Gandhi Square et ses barres de métal sur lesquelles les gens se perchaient de manière inconfortable, en attendant leur autobus sous le noble regard de Gandhi, et que nous sommes allées prendre un latte dans un café à la mode situé au coin de la rue.

\section{ESPACE PUBLIC ET VILLE « EXEMPLAIRE »}

Pour les spécialistes de la ville, l'espace public revêt une importance toute particulière en ville. Depuis l'Agora d'Athènes et le fonctionnement politique du Forum romain, l'espace public a toujours été perçu comme étant en relation avec la sphère publique, comme une expression de la gouvernance urbaine et de la gestion quotidienne de la vie publique urbaine ${ }^{1}$. C'est dans les espaces publics que les diverses identités politiques peuvent s'exprimer. «[...] La myriade d'anfractuosités que l'on trouve dans les villes offre aux millions de déshérités, de déplacés et de sans papiers dépouillés de la citoyenneté la possibilité d'acquérir un capital politique ${ }^{2}$.»

L'espace public reflète les relations qui existent entre la ville et ses habitants, les citadins. Les citadins pauvres n'ont qu'un accès limité aux espaces de loisirs urbains payants, et leurs espaces résidentiels sont bien souvent inadaptés. Traditionnellement, les espaces publics sont également des lieux où les personnes économiquement marginalisées peuvent en partie gagner leur vie. Dans les économies en développement, cela se traduit souvent par la présence du commerce informel et de la mendicité. En s'inspirant du

1. Canniffe, Eamonn, Urban Ethic. Design in the Contemporary City, Oxon, Routledge, 2006.

2. Amin Ash, «The Good City», in Urban Studies, n 43 (5), mai 2006, p. 1012. 
Lefèbvre's Right to the City, Don Mitchell ${ }^{3}$ argues that public spaces absorb those marginalised from the rights of the citadin.

Public spaces are also the site of interaction between different urban identities. It is where a range of urban identities may regard each other, resulting in what Fran Tonkiss ${ }^{4}$ refers to as side-by-side particularity; a state where difference is unexceptional and left unassimilated. Ash Amin ${ }^{5}$ drawing on Chantal Mouffe ${ }^{6}$, argues that public space is central to building urban environments where there is an ease with this unassimilated difference and a culture of agonistic disagreement. Amin also draws our attention to the importance of public space to a sense of urban solidarity, "a certain kind of sociality which comes from particular forms of gathering in public space”".

Zygmunt Bauman ${ }^{8}$ in his discussions of ethics outside the fixed moralities of modernity, speaks to this solidarity. Following the works of Emmanuel Levinas ${ }^{9}$, for Bauman ethical life lies in a sense of concern for the other. He argues that this concern depends on knowledge of the other and that solidarity with the other emerges when this knowledge is at its "richest and most intimate". For urban theorists this rich and intimate knowledge comes with propinquity - Nigel Thrift and Ash Amin ${ }^{10}$ use this term to imply a variegated and complex sense of community. In particular, following Henri Lefèbvre" mundane, but also the community of improvisation, intuition and play". In this situationist approach to the city, everyday life is the "sum total of relations which make the human - and every human being - a whole which

3. Mitchell Don, The Right to the City. Social Justice and the Fight for Public Space, New York, Guilford Press, 2003.

4. Tonkiss Fran, "The Ethics of Indifference: Community and Solitude in the City", in International Journal of Cultural Studies, $\mathrm{n}^{\circ} 6$ (3), 2003.

5. Amin Ash, "The Good City", op. cit.

6. Mouffe Chantal, The Democratic Paradox, London, Verso, 2000.

7. Amin Ash, "The Good City", op. cit., p. 1012.

8. Bauman Zygmunt, Postmodern Ethics, Oxford, Blackwell, 1993.

9. Levinas Emmanuel, Entre nous, London, Continuum, 2006.

10. Amin Ash, Thrift Nigel, Cities. Reimagining the Urban, Cambridge, Polity, 2002, p. 47.

11. Lefèbvre Henri, La Production de l'espace, Paris, Anthropos, 1974. 
Droit à la ville d'Henri Lefèbvre, Don Mitchell ${ }^{3}$ indique que les espaces publics « absorbent » tous ceux qui sont exclus du droit à la citadinité.

Les espaces publics sont également des lieux d'interaction entre différentes identités urbaines. C’est là que ces identités peuvent se côtoyer, entraînant ce que Fran Tonkiss ${ }^{4}$ appelle la singularité de la co-présence, c'est-à-dire une situation dans laquelle la différence est à la fois tout à fait ordinaire et laissée pleine et entière. Ash $\mathrm{Amin}^{5}$, s'inspirant de Chantal $\mathrm{Mouffe}^{6}$, soutient que l'espace public joue un rôle essentiel dans la construction d'environnements urbains où cette différence assumée ainsi qu'une culture de désaccord fondée sur l'antagonisme ne posent pas de problèmes. Amin attire également notre attention sur l'importance de l'espace public comme producteur de solidarité urbaine, « une sorte de socialité qui provient de formes particulières de regroupement au sein de l'espace public ${ }^{7} »$.

Zygmunt Bauman ${ }^{8}$, dans ses discussions sur l'éthique dégagée des moralités figées de la modernité, adhère également au principe de cette solidarité. En accord avec les travaux d'Emmanuel Levinas', Bauman pense que vivre sa vie de façon morale, c'est avoir de la considération pour les autres. Il indique qu'une telle considération dépend de la connaissance que l'on a de l'autre et que la solidarité envers l'autre ne peut se développer que lorsque cette connaissance atteint son niveau «le plus riche et le plus intime ». Pour les théoriciens de l'urbain, cette connaissance riche et intime va de pair avec la proximité: Nigel Thrift et Ash Amin ${ }^{10}$ utilisent ce terme pour définir un sentiment composite et complexe de communauté. En accord avec Henri Lefèbvre ${ }^{11}$, ils parlent d'une « communauté du banal et du terre-à-terre, mais également d'une communauté de l'improvisation, de l'intuition et du jeu ». Dans cette approche situationniste de la ville, la vie quotidienne est la «somme des relations qui font de l'homme - et de

3. Mitchell Don, The Right to the City. Social Justice and the Fight for Public Space, New York, Guilford Press, 2003.

4. Tonkiss Fran, «The Ethics of Indifference: Community and Solitude in the City », in International Journal of Cultural Studies, $n^{\circ} 6$ (3), septembre 2003.

5. Amin Ash, «The Good City », op. cit.

6. Mouffe Chantal, The Democratic Paradox, Londres, Verso, 2000.

7. Amin Ash, «The Good City», op. cit., p. 1012.

8. Bauman Zygmunt, Postmodern Ethics, Oxford, Blackwell, 1993.

9. Levinas Emmanuel, Entre nous, Londres, Continuum, 2006.

10. Amin Ash, Thrift Nigel, Cities. Reimagining the Urban, Cambridge, Polity, 2002, p. 47.

11. Lefèbvre Henri, La Production de l'espace, Paris, Anthropos, 1974. 
brings into play the totality of the real, albeit in a certain manner which is always partial and incomplete: friendship, comradeship, love, the need to communicate, play, etc ${ }^{12}$." For geographers the "good ${ }^{13}$ " city is one in which there is engagement and connection for urban others. The ethical city for these writers is neither a utopian "love thy neighbour" message ${ }^{14}$, nor is it constrained by a normative (and universalised) regime of ethical conduct ${ }^{15}$. It is also not a promotion of an ethical relativism; rather it is a position, which Bauman ${ }^{16}$ terms as après-devoir - an ethic based on an awareness and acceptance of ambivalence ${ }^{17}$. The public life which makes this ethic of care for others possible requires public space for its articulation.

\section{VISIONING SPACES OF JUSTICE IN JOHANNESBURG}

There are three vision documents for the city of Johannesburg that deal with public space ${ }^{18}$. In 2002, Joburg 2030, a document embracing profoundly the principles of neo-liberal urban planning, was launched. The central motif of this document is the image of Johannesburg as a world-class African city, and this slogan has persisted. Public space does not feature overtly in the document, and many have argued that this particular vision of the city is anti-poor and exclusionary. In response to these criticisms in 2005, the city of Johannesburg launched the Human Development Strategy to

12. Amin Ash et Thrift Nigel, Cities. Reimagining the Urban, op. cit., p. 47.

13. Amin Ash, "The Good City", op cit.

14. Ibid.

15. Bauman Zygmunt, Postmodern Ethics, Oxford, Blackwell, 1993.

16. Ibid.

17. Dirsuweit Teresa, "Between Ontological Security and the Right to Difference", in Autrepart, n' 42 ("Variations"), 2007, p. 53-71.

18. Dirsumeit Teresa, "New Urbanism, Public Space and Spatial Justice in Johannesburg. The Case of 44 Stanley Ave", in Annales de Geographie, n' 665-666, 2009, p. 76-93. 
chaque être humain - un ensemble qui met en jeu la totalité du réel, mais d'une manière qui est toujours partielle et incomplète: l'amitié, la camaraderie, l'amour, le besoin de communiquer, de jouer, etc ${ }^{12} \ldots »$. Pour les géographes, la ville « exemplaire ${ }^{13}$ » est celle dans laquelle on trouve engagement et relation avec les autres citadins. Dans ces approches, la ville éthique n'est ni un message utopique du genre "aime ton voisin ${ }^{14}$ », ni une ville contrainte par un régime normatif (et universalisé) de bonne conduite morale ${ }^{15}$; elle n'est pas non plus la promotion d'une forme de relativisme moral. Il s'agit plutôt d'une posture que Bauman ${ }^{16}$ appelle « l'après-devoir » - c'est-à-dire une morale fondée sur la conscience et l'acceptation de l'ambivalence $^{17}$. Pour concrétiser cette morale fondée sur le care $^{18}$ envers les autres, la vie publique a besoin d'espace public.

\section{QUeLle JUSTiCe SPATIALE POUR JohaNNESburg?}

Il existe trois documents de prospective pour la Ville de Johannesburg qui traitent de l'espace public ${ }^{19}$. L'année 2002 a vu le lancement d'un document intitulé Joburg 2030, qui adoptait en grande partie les principes de l'urbanisme néolibéral. Le thème central de ce document posait Johannesburg comme ville globale d'Afrique (World class African city), un slogan encore d'actualité. Ce document ne traite pas explicitement de l'espace public, et nombreux sont ceux qui ont soutenu que cette vision particulière de la ville était hostile aux pauvres et excluante. En réponse à ces critiques, en 2005, la ville de Johannesburg a lancé sa «stratégie de développement humain » dans un document intitulé Human Development Strategy (HDS)

12. Amin Ash, Thrift Nigel, Cities. Reimagining the Urban, op. cit., p. 47.

13. Amin Ash, «The Good City », op. cit.

14. Ibid.

15. Bauman Zygmunt, Postmodern Ethics, Oxford, Blackwell, 1993.

16. Ibid.

17. Dirsuweit Teresa, «Between Ontological Security and the Right to Difference », in Autrepart, $\mathrm{n}^{\circ} 42$ ("Variations »), 2007, p. 53-71.

18. Le terme de care est difficilement traduisible en français et sera donc conservé tel quel dans la suite de l'article; il s'approche des notions d'humanisme, d'égard, de solidarité et de générosité [NDT].

19. Dirsumeit Teresa, "New Urbanism, Public Space and Spatial Justice in Johannesburg. The Case of 44 Stanley Ave », in Annales de Geographie, n 665-666, 2009, p. 76-93. 
complement Joburg 2030. This Strategy tempers the neo-liberal pragmatism of Joburg 2030:

A world-class African city for all - this is Joburg's commitment to the poor... [emphasis added $]^{19}$

A human development perspective of the HDS recognises that people are the City's biggest asset and that they need to be supported and encouraged to realise their full potential to become fully-fledged urban residents ${ }^{20}$.

The emphasis of the Human Development Strategy is the promotion of cohesion and inclusion.

Cities in pursuit of world-class status need to strike a fine balance between their conflicting imperatives. The sometimes uneasy relationship between economic growth and social responsibilities is reflected in social discord as the minority of city residents reaps the benefits of growth while many remain in conditions of poverty. A social inclusion agenda seeks to build social cohesion among all city residents, to build community trust in the City, and to create positive partnerships for social inclusion in the city ${ }^{21}$.

Public space is overtly engaged with in this vision document, and the creation and transformation of existing public spaces is seen as one of the pillars of encouraging "the public to interact in its full diversity". There is also an acknowledgement that public spaces are essential to the poor, who have limited access to private space.

In 2006, the Growth and Development Strategy replaced the Human Development Strategy and Joburg 2030. This vision document was intended to resolve the many conflicting terms between the preceding vision documents. Here public space is seen as a means to "proactively absorb" the poor,

"Proactive absorption" does not mean wanting to take in more poor people so that they end up in informal accommodation, stranded because they cannot pay for transport, unable to access services or social

19. City of Johannesburg, Human Development Strategy, Johannesburg, City of Johannesburg, 2005, p. 4.

20. Ibid., p. 2.

21. Ibid., p. 10. 
en complément de Joburg 2030. Cette stratégie vient tempérer le pragmatisme néolibéral de Joburg 2030:

Une ville globale africaine pour tous - c'est là l'engagement de la ville de Joburg envers les pauvres ${ }^{20} \ldots$

La HDS reconnaît que les habitants représentent le plus grand atout de la ville et qu'ils ont besoin d'être soutenus et encouragés pour réaliser au maximum leur potentiel en vue de devenir des citadins à part entière ${ }^{21}$.

La HDS met de fait l'accent sur la promotion de la cohésion et de l'inclusion:

Les villes qui cherchent à obtenir le statut de ville globale doivent trouver un équilibre subtil entre plusieurs impératifs contradictoires. Les relations parfois difficiles entre croissance économique et responsabilités sociales s'expriment au travers des dissensions sociales liées au fait qu'une minorité de résidants de la ville récoltent les fruits de la croissance alors que beaucoup continuent à vivre dans la pauvreté. Un programme d'inclusion sociale cherchera donc à développer la cohésion sociale entre tous les résidants de la ville, à construire la confiance de la communauté envers la Municipalité, et à créer des partenariats positifs pour l'inclusion sociale au sein de la ville ${ }^{22}$.

Ce document prospectif s'engage ouvertement dans une discussion sur l'espace public et la création et la transformation des espaces publics existants sont perçues comme les piliers permettant d'encourager « les habitants à interagir dans toute leur diversité ». On y reconnaît également que les espaces publics sont essentiels aux pauvres dont l'accès à l'espace privé est limité.

En 2006, un document intitulé Growth and Development Strategy (GDS) a remplacé le HDS et Joburg 2030. L'objectif de ce document prospectif était de résoudre les nombreuses contradictions émaillant les documents prospectifs précédents. Avec le GDS, l'espace public est désormais perçu comme un moyen « d'intégrer les pauvres de manière active »:

"L'intégration active» ne veut pas dire accueillir encore plus de pauvres pour les voir finir dans des logements informels, coincés parce qu'ils n'ont pas les moyens d'utiliser les transports, privés d'accès aux services ou aux équipements sociaux, et contraints d'avoir recours à

20. City of Johannesburg, Human Development Strategy, Johannesburg, City of Johannesburg, 2005, p. 4. C'est l'auteur qui souligne.

21. Ibid., p. 2.

22. Ibid., p. 10. 
amenities, and forced to behave in irregular, perhaps even criminal, activities to get by. Such people are not "absorbed into the city" - they live a half life on its periphery, never able to enjoy the real opportunities and benefits of urban life ${ }^{22}$.

There is, however, a small yet significant shift in the discursive basis of the treatment of the poor in public spaces. Where public spaces are seen as essential to the care of the urban poor in the Human Development Strategy, in the Growth and Development Strategy, public space is viewed as somewhere where the poor are to be tolerated:

Making allowances for the poor in how the built environment and use of public space is regulated and managed ${ }^{23} \ldots$

There is no doubt that urban governance structures in Johannesburg recognise the importance of public space in the promotion of a city which is more democratic, more accessible and more inclusive. Furthermore, these structures have a clear objective to "improve the opportunities for citizen interaction through attractive and accessible public space ${ }^{24}$ ". Nevertheless, the reality of public space in Johannesburg is that the way in which public spaces are constructed, revitalised and managed in the city limits the development of a community of improvisation, intuition and play. Indeed, Neil Smith ${ }^{25}$ would argue that the incident at Ghandi Square is unsurprising,

Crime of course was a central mobilizing issue in Giuliani's remake of New York as a revanchist city where reactionary revenge against those who has "stolen the city" was a central motif, and the general politics of revanchism in South Africa are parallel insofar as the state has asserted its right over that of the public in a thoroughly asymmetrical way ${ }^{26}$.

To elucidate this point, I would like to return to Lefèbvre's ontology of urban space. For Lefèbvre, space is produced through the interweaving of

22. City of Johannesburg, Growth and Development Strategy, Johannesburg, City of Johannesburg, 2006, p. 57.

23. Ibid., p. 58-59.

24. Ibid., p. 93.

25. Sмiтн Neil, The New Urban Frontier. Gentrification and the Revanchist City, London, Routledge, 1996. Sмітн Neil, "Global Social Cleansing. Postliberal Revanchism and the Export of Zero Tolerance", in Social Justice, $n^{\circ} 28$ (3), 2001; Sмiтн Neil et Low Setha, "Introduction. The Imperative of Public Space", in The Politics of Public Space, Low Setha and Sмiтн Neil (dir.), New York, Routledge, 2006.

26. Sмiтн Neil, Low Setha, "Introduction. The Imperative of Public Space", op. cit. 
des pratiques illégales voire criminelles pour s'en sortir. De telles personnes ne sont pas « intégrées dans la ville » - elles vivent une demi-vie à sa périphérie, et ne peuvent jamais profiter des vraies opportunités et avantages offerts par la vie urbaine ${ }^{23}$.

On trouve cependant dans ce document un changement léger mais significatif dans le discours sur le traitement des pauvres dans les espaces publics: là où, dans le HDS, les espaces publics étaient perçus comme essentiels pour les pauvres urbains, dans le GDS, l'espace public est perçu comme le lieu où les pauvres doivent être tolérés:

Donner des possibilités aux pauvres dans la manière dont l'espace bâti et l'usage de l'espace public sont régulés et gérés ${ }^{24} \ldots$

Il ne fait aucun doute que les structures de gouvernance urbaine à Johannesburg reconnaissent l'importance de l'espace public dans la promotion d'une ville plus démocratique, plus accessible et plus inclusive. En outre, l'objectif de ces structures est clairement « d'améliorer les possibilités d'interaction entre les citoyens au moyen d'espaces publics attrayants et accessibles $^{25}$ ». Mais la réalité des espaces publics à Johannesburg fait que la manière dont ils sont construits, revitalisés et gérés limite le développement collectif de l'improvisation, de l'intuition et du jeu. En ce sens, Neil Smith ${ }^{26}$ ne trouverait pas surprenante notre aventure de Gandhi Square.

La criminalité fut bien sûr un ressort central de la reconstruction de New York par Giuliani qui en fit une ville revanchiste, où la vengeance réactionnaire contre ceux qui avaient "volé la ville » fut un thème central; la politique revanchiste généralisée en Afrique du Sud offre un parallèle avec la situation new-yorkaise en ce sens que l'État a affirmé son droit sur celui des habitants d'une manière tout à fait asymétrique ${ }^{27}$.

Pour éclaircir ce point, j'aimerais retourner à l'ontologie de l'espace urbain proposée par Lefebvre. Pour lui, l'espace est le produit de l'entrelacement de

23. City of Johannesburg, Growth and Development Strategy, Johannesburg, City of Johannesburg, 2006, p. 57.

24. Ibid., p. 58-59.

25. Ibid., p. 93.

26. Smith Neil, The New Urban Frontier. Gentrification and the Revanchist City, Londres, Routledge, 1996. Sмiтн Neil, "Global Social Cleansing. Postliberal Revanchism and the Export of Zero Tolerance ", in Social Justice, n 28 (3), 2001; Sмiтн Neil et Low Setha, "Introduction. The Imperative of Public Space », in The Politics of Public Space, Low Setha et Sмiтн Neil (dir.), New York, Routledge, 2006.

27. Sмiтн Neil, Low Setha, "Introduction. The Imperative of Public Space ", op. cit. 
spatial practice, representations of space and representational space. Representations of space encompass "the space of scientists, planners, urbanists, technocratic subdividers and social engineers ${ }^{27}$ ". It is this spatial modality which is most concerned with the "order" of the relation of spatial production, and Lefèbvre argues that this order is associated with a Cartesian spatial engagement; fixing and ordering the functioning of public spaces and the activities within - or, to put it in the pragmatist discourse of urban management - it is about making cities work.

\section{New URbanist Renewal \\ AND REPRESENTATIONAL SPACE}

For urban planners and architects in Johannesburg, representations of space have overwhelmingly followed the principles of new urbanism in design and the principles of privatisation in political and economic spatial governance. And so while there are different types of urban public space in the city - the publicness which emerges in the privately owned shopping mall and the publicness of the street and the square are ostensibly different - representations of space, the order of urban space in Johannesburg, follows a pattern. In the extraordinary case of Melrose Arch, for example, this pattern is articulated through the simulation of new urbanist developments in major cities in the world. In the case of South-West City Improvement District, older building stock is rapidly being revitalised in mixed-use precincts. Local government has committed itself to public-private partnership governance, and the inner city is now a patchwork of city improvement districts. In addition, as new urbanist private developments grow in and around the city, the city is increasingly becoming a privatised new urbanist archipelago. New urbanism, however, has

27. Lefèbvre Henri, La Production de l'espace, op. cit., p. 48. 
pratiques spatiales, de représentations de l'espace et d'espaces de représentation. Les représentations de l'espace comprennent «l'espace conçu, celui des savants, des planificateurs, des urbanistes, des technocrates « diviseurs » et des ingénieurs sociaux ${ }^{28} »$. C'est cette modalité spatiale qui s'intéresse le plus à « l'ordre » de la relation de la production spatiale, et Lefebvre soutient que cet ordre est associé à une façon cartésienne d'envisager l'espace, laquelle consiste à définir et à mettre de l'ordre dans le fonctionnement des espaces publics et des activités en leur sein - ou, pour employer le discours pragmatique de la gestion urbaine - faire en sorte que la ville fonctionne.

\section{RENOUVELLEMENT URBAIN, NEW URBANISM ET ESPACE REPRÉSENTATIONNEL}

Pour les urbanistes et les architectes de Johannesburg, les représentations de l'espace ont en très grande majorité suivi les principes proposés par le New Urbanism en matière de conception urbaine, et le principe de la privatisation en ce qui concerne la gouvernance spatiale dans ses dimensions politique et économique. Ainsi, alors qu'on trouve différents types d'espaces publics en ville - le caractère public des centres commerciaux privés et celui des rues et places sont évidemment différents - les représentations de l'espace et l'ordre de l'espace urbain à Johannesburg suivent un certain modèle. Dans le cas tout à fait remarquable de Melrose Arch, par exemple, ce processus se reflète dans l'imitation de programmes inspirés du New Urbanism et réalisés dans d'autres grandes villes étrangères. Dans le cas du South-West City Improvement District, les plus vieux bâtiments font l'objet d'une revitalisation rapide destinée à produire des quartiers à usage mixte. La municipalité s'est engagée dans un partenariat public-privé, et le centreville est aujourd'hui un patchwork de City Improvement Districts ${ }^{29}$. De plus, au fur et à mesure que sont construits des programmes privés dans la ville et en périphérie, Johannesburg se transforme de plus en plus en archipel privatisé du New Urbanism. Pourtant, le New Urbanism a fait l'objet de

28. Lefèbvre Henri, La Production de l'espace, op. cit., p. 48.

29. Il s'agit de périmètres sécurisés soumis à une micro-gouvernance publiqueprivée locale dans lesquels des taxes supplémentaires sont levées pour améliorer la qualité des services [NDT]. 
been heavily criticised ${ }^{28}$. Michael Dear ${ }^{29}$ for example, describes new urbanism as Howard's concept of recycling the garden city as the solution to urban problems such as insecurity, alienation, urban decay and inadequate transport infrastructure. For those concerned with urban justice, new urbanism is perturbing, as this planning style frequently results is homogenous and insular communities ${ }^{30}$. For Richard Sennett ${ }^{31}$ new urbanism is "world's apart from the everyday disorders of life; these kitschy, pseudocommunities that advertise themselves as antidotes to suburban sprawl provide little home for difference - differences of the kind that lead to conflicts of ethnicity, class or sexual preference".

To return to Lefèbvre's ontology of space, the guard's disciplinary action within Gandhi Square points to a tension between representations of space and conflicting representational space. The modality - and these modalities are co-present and interweaved - of spatial practice refers to the way in which the city is produced through the workings of a particular society, for "a society secretes that society's space ${ }^{32}$ ". This is the spatiality that gradually emerges through daily routine and networks through the city. In the case of Gandhi Square, the spatial practice of this bus terminus (especially since buses are less frequent than they should be) includes the daily routine of being taken from suburban centres to inner city spaces of economic production. The modality of representational space is the space of "inhabitants" and "users". "This is the dominated - and hence passively experienced - space which the imagination seeks to change and appropriate. It overlays physical space, making symbolic use of its objects ${ }^{33}$." Gandhi Square, for its

28. Dirsumeit Teresa, Schattauer Florian, "Fortresses of Desire. Melrose Arch and the emergence of urban tourist spectacle", in Geojournal, n' 60 (3), 2004; Dirsuweit Teresa, "New Urbanism, Public Space and Spatial Justice in Johannesburg. The Case of 44 Stanley Ave", op. cit., p. 76-93.

29. Dear Michael, The Postmodern Urban Condition, Oxford, Blackwell, 2000.

30. Talen Emily, "Sense of Community and Neighbourhood Form. An Assessment of the Social Doctrine of New Urbanism", in Urban Studies, n 36 (8), 1999.

31. Sennet Richard, "Street and Office: Two Sources of Identity", in On the Edge. Living with Global Capitalism, Hutton Will and Giddens Anthony (dir.), London, Jonathan Cape, 2000, p. 70.

32. Lefèbvre Henri, La Production de l'espace, op. cit., p. 48.

33. Ibid., p. 49. 
sérieuses critiques $^{30}$. Michael Dear ${ }^{31}$ par exemple, décrit le New Urbanism comme une sorte de produit recyclé dérivé du concept de la Cité-jardin de Howard et considéré comme solution-miracle aux problèmes urbains tels que l'insécurité, l'aliénation, le déclin urbain et l'inadaptation des infrastructures de transport. Pour ceux qui s'intéressent à la justice urbaine, le New Urbanism est un phénomène inquiétant, car ce style d'urbanisme entraîne la plupart du temps la création de quartiers homogènes et insulaires $^{32}$. Pour Richard Sennett ${ }^{33}$, le New Urbanism est ainsi « diamétralement opposé au désordre quotidien de la vie; ces pseudo-communautés kitsch qui se présentent comme l'antidote à l'étalement suburbain offrent peu de place à la différence - différences qui mènent aux conflits d'ethnicité, de classe sociale ou de préférence sexuelle ».

Pour en revenir à l'ontologie de l'espace de Lefêbvre, la mesure disciplinaire prise par le garde à Gandhi Square montre la tension existant entre les représentations de l'espace et un espace représentationnel construit en contradiction avec ces dernières. Les modalités - et ces modalités sont coprésentes et interdépendantes - de la pratique spatiale font référence à la manière dont la ville est produite à travers les rouages d'une société particulière, car « la pratique spatiale d'une société secrète son espace ${ }^{34} »$. Il s'agit là d'une spatialité qui émerge graduellement de la routine quotidienne et des réseaux à travers la ville. Dans le cas de Gandhi Square, la pratique spatiale associée à ce terminus de bus (d'autant plus que les bus passent moins fréquemment qu'ils ne devraient) inclut la routine quotidienne des déplacements des banlieues jusqu'aux espaces de production économique du centre-ville. La modalité de l'espace de représentation est l'espace des « habitants » et des « usagers ». "C'est l'espace dominé et subi, que l'imagination tente de s'approprier et de modifier. Il recouvre ainsi l'espace physique en utilisant symboliquement ses objets ${ }^{35}$ ». Gandhi Square est, pour

30. Dirsumeit Teresa, Schattauer Florian, « Fortresses of Desire. Melrose Arch and the emergence of urban tourist spectacle ", in Geojournal, n' 60 (3), 2004; Dirsuweit Teresa, « New Urbanism, Public Space and Spatial Justice in Johannesburg. The Case of 44 Stanley Ave ", op. cit., p. 76-93.

31. Dear Michael, The Postmodern Urban Condition, Oxford, Blackwell, 2000.

32. TALen Emily, «Sense of Community and Neighbourhood Form. An Assessment of the Social Doctrine of New Urbanism », in Urban Studies, no 36 (8), 1999.

33. Sennet Richard, "Street and Office: Two Sources of Identity", in On the Edge. Living with Global Capitalism, Hutton Will et Giddens Anthony (dir.), Londres, Jonathan Cape, 2000, p. 70.

34. Lefèbvre Henri, La Production de l'espace, op. cit., p. 48.

35. Ibid., p. 49. 
users, is a space of resting, waiting, thinking, reading, and so forth. It is an interstitial space of pause before being moved out of the city to the suburban spaces of home, rest, and leisure. Clearly, in Gandhi Square the representational spatial modality and representations of space are at odds with one another, and thus the "zero tolerance" disciplinary control.

Ironically, new urbanist planning in its current practice acknowledges the importance of the modality of representational space. It works with non-verbal symbols and signs and the everyday lived practice of urban inhabitants. For example the marketing promises of Melrose $\mathrm{Arch}^{34}$ speaks to the lived practice of urban life,

Melrose Arch is the first private development that offers accessible public space on wide streets with a number of "third places" in which people can interact. It consists of offices, shops, restaurants, gym, hotel, squares with benches, open streets and while it is a managed environment it offers uninhibited but controlled access to everyone... Melrose Arch is a microcosm of publicness... [emphasis added] ${ }^{35}$.

The marketing promises of 44 Stanley Ave also offer a space that speaks to a particular urban imaginary,

The whole building has a playground appeal and as such attracts many playful, colourful and creative people to it... the focus is on urban renewal and the task is to provide an unparalleled lifestyle centre. The wonderfully eclectic mix of shops attest to this and it will only take one visit to be hooked. The stores are a blend of the curious and quirky, the adventurous and the sublime ${ }^{36} \ldots$

The form of representational meaning articulated in this space, however, is that of middle-class consumers and, at all costs, the image of a middleclass representational fantasy is maintained. In this way these environments are constructed to suit the imaginaries of the urban middle classes and are secured to ensure that urban others do not disrupt this image. The same is true of Gandhi Square - this space is secured and the people who enter the

34. Dirsumeit Teresa, Schattauer Florian, "Fortresses of Desire. Melrose Arch and the Emergence of Urban Tourist Spectacle", op. cit.

35. Marketing Concepts, Melrose Arch, Making the Space We Live In Worth Living In, Marketing Brochure, Johannesburg.

36. 44 Stanley website. 
ses usagers, un espace de repos, d'attente, de réflexion, de lecture, entre autres. C'est l'espace interstitiel dans lequel les usagers font une pause avant d'être transportés hors du centre-ville vers les banlieues où ils vivent, se reposent et se divertissent. À l'évidence, la modalité spatiale représentationnelle à Gandhi Square ne cadre pas avec les représentations de cet espace, ni avec l'application disciplinaire du principe de «tolérance zéro ».

De manière ironique, le New Urbanism, dans sa pratique actuelle, reconnaît l'importance de l'espace représentationnel. Cette planification use de symboles et de signes non verbaux et s'appuie sur la pratique quotidienne des citadins. Par exemple, l'argumentaire commercial de Melrose Arch ${ }^{36}$ s'adresse aux pratiques vécues de la ville:

Melrose Arch est le premier programme privé qui offre un espace public accessible sous la forme de larges avenues ainsi qu'un certain nombre « d'espaces tiers » au sein desquels les gens peuvent se rencontrer. Le programme comprend des bureaux, des magasins, des restaurants, des salles de sport, un hôtel, des places avec des bancs et des rues ouvertes, et bien qu'il s'agisse d'un environnement contrôlé, il offre un accès ouvert à tous mais surveillé... Melrose Arch est un microcosme d'espace public ${ }^{37} \ldots$

L'argumentaire commercial du 44 Stanley Avenue met également en valeur un espace s'adressant à un imaginaire urbain particulier :

Tout le bâtiment rappelle une cour de récréation et attire ainsi des gens enjoués, originaux et créatifs... la priorité est au renouvellement urbain et l'objectif est de produire un centre qui offre un mode de vie sans pareil. Le mélange merveilleusement éclectique de magasins témoigne de cela et il vous suffira d'une visite pour être "accroché ». Les magasins offrent un mélange de curieux, de décalé, d'aventureux et de sublime ${ }^{38} \ldots$

Cependant, le sens représentationnel exprimé dans cet espace est celui d'un consommateur de la classe moyenne, et c'est le fantasme représentationnel de la classe moyenne qui y est mis en scène à tout prix. Ainsi, ces types d'environnement sont construits pour convenir à l'imaginaire de la classe moyenne urbaine et sont sécurisés pour empêcher que cette image soit dérangée par la présence de l'Autre. Il en est de même pour Gandhi Square: les gens qui pénètrent place dans cet espace sécurisé et les activités

36. Dirsumeit Teresa, Schattauer Florian, « Fortresses of Desire. Melrose Arch and the emergence of urban tourist spectacle ", op. cit.

37. Marketing Concepts, Melrose Arch, Making the space we live in worth living in, Marketing Brochure, Johannesburg.

38. Site internet de 44 Stanley. 
space and the activities that take place within the space are selected and controlled. Although they speak to the imaginary of playful, cosmopolitan and interactive environments - these are highly mediated spaces where, in maintaining a constructed sense of "order", extraordinary limitations are placed on who enters the space and what is enacted within the space. The opportunities for "a whole that brings into play the totality of the real" are circumscribed and limited. There is almost no capacity for these spaces to offer unexpected moments of spontaneous interaction - the kind of sociality which could result in a great sense of connection with urban others.

Furthermore, in speaking to representational space - these developments exclude through their symbolic orders. The case of 44 Stanley Ave for example, although the owner claimed that the space was:

... totally non exclusive and I think that it embraces South Africans and it also embraces foreigners... that was the model that I worked on, when I say model, I mean my own model, that it was a non exclusive, non ageist, non sexist, non-, non-, non- ${ }^{37} \ldots$,

the owners and shopkeepers also acknowledged that the "aesthetics" of 44 Stanley appeal to a very small portion of Johannesburg residents.

But if you look at the clientele that does come here, it is quite a specific set of people...I mean if you look at the people who work in the offices around here, they don't seem to have that much interaction with the space.

No they don't.

Why do you think that it is?

Because, they don't... because it fits into a certain aesthetic. It fits into a group of people who appreciate an aesthetic... You get a lot of call centres (and I'm not judging here) and a certain ilk of people who work in these buildings ${ }^{38} \ldots$

So although the owners and retailers in the space perceived the development as inclusive and made a number of efforts to develop equal 
qui s'y déroulent sont sélectionnés et contrôlés. Bien qu'ils s'adressent à un imaginaire spatial ludique, cosmopolite et interactif, ce sont des espaces très contrôlés dans lesquels, par la construction d'un sens élaboré de "l'ordre », des restrictions importantes sont mises en place à l'égard de ceux qui y pénètrent et des activités qui s'y déroulent. Les possibilités d'y saisir « une totalité qui puisse mettre en jeu l'ensemble du réel » sont circonscrites et limitées. Ces espaces sont pratiquement incapables d'offrir des moments inattendus d'interaction spontanée, le type de relation sociale qui permettrait d'entraîner un sentiment fort de connexion avec l'Autre dans la ville.

En outre, dans leur façon d'aborder l'espace représentationnel, de tels programmes excluent par leur ordre symbolique. C'est le cas par exemple du 44 Stanley Avenue, car bien que le propriétaire ait déclaré:

[il s'agit d'un espace] absolument inclusif, je pense qu'il s'adresse aussi bien aux Sud-Africains qu'aux étrangers... et c'est le modèle sur lequel j'ai travaillé, et quand je dis "modèle ", je veux parler de mon propre modèle, un modèle dont sont absents l'exclusion, la discrimination par l'âge et le sexisme, et bien d'autres choses encore ${ }^{39}$,

les propriétaires des magasins et les commerçants admettent que l'esthétique du 44 Stanley n'attire qu'un très petit nombre d'habitants de Johannesburg.

Mais si on regarde la clientèle qui vient ici, on voit bien qu'il s'agit d'un type de clientèle particulière... Je veux dire que si l'on regarde qui travaille dans les bureaux des alentours, et bien ces gens là ne viennent pas ici.

C'est vrai.

Pourquoi croyez-vous qu'ils n'y viennent pas?

Parce qu'ils ne sont pas... parce que 44 Stanley, c'est une esthétique particulière. Ce lieu concerne un groupe de gens qui apprécient une esthétique... Vous avez beaucoup de centres d'appel (et ce que je dis là n'est pas un jugement de valeur) et des gens d'un certain genre qui travaillent dans ces bâtiments ${ }^{40} \ldots$

Ainsi, bien que les propriétaires des magasins et les commerçants perçoivent l'espace comme inclusif et aient fait un effort certain pour développer des relations d'égal à égal avec leur personnel, la sensibilité spatiale

39. Entretien avec le propriétaire du 44 Stanley, 2005.

40. Entretien avec un propriétaire de magasin, 2005. 
rela-tionships between themselves and their staff, in speaking to a particular spatial sensibility, the space became awkward for a range of users.

[44 Stanley is] so very white [laughs]... you know there's too much white people, but they're quite a nice bunch ${ }^{39}$.

[It attracts] the wealthy, of course you get the odd artsy student, but it is mainly middle-aged upper income ${ }^{40}$.

I call them mueslis, you know, rich, white, healthy ${ }^{41} \ldots$

No I never eat here; I bring my sandwiches and eat them there on the other side ${ }^{42}$.

... it's just an exclusive white kind of set up. It's only the [hip] and happening black people who know about this place. And the black people who are working around here; because even the black people, they ask, "what do you do there, what is that place?"... for me, it's not my kind of set up, you know I love...my rowdy friends, you know the people around who would like to scream or dance, you need to feel free - not every time you make a move someone will like [shows a glare]... The age gap just comes to me... For me it's just a bit too exclusive ${ }^{43}$.

Although they are different spaces, Gandhi Square, Melrose Arch, and 44 Stanley Ave, speak to a middle-class representational space as part of a deliberate and planned representation of space. As a consequence, the spontaneity that makes public space an important component of a particular sociality that includes play, agonistic disagreement and the lived appropriation of space is lost. In this loss is the potential for a greater inclusivity and sense of solidarity and care for the other.

\section{ConcLusion}

You may be reading this and, like me, you may be feeling a vague scepticism gnawing at you. Surely, if we let representational space become a dominant modality for urban, for public, space in Johannesburg, it would

39. Interview, Worker 2005.

40. Interview, Retailer 2005.

41. Interview, Retailer 2005.

42. Interview, Worker 2005.

43. Interview, Worker, 2005. 
particulière du lieu fait que l'espace est devenu inadapté pour toute une gamme d'utilisateurs.

[44 Stanley], c'est tellement blanc... [rire] Vous savez, il y a trop de blancs qui viennent ici, mais ils sont plutôt sympa ${ }^{41}$.

[44 Stanley attire] les riches, bien sûr vous trouverez à l'occasion des étudiants en art, mais on trouve principalement des gens dans la cinquantaine appartenant à la tranche supérieure de revenus ${ }^{42}$.

Je les appelle « les p’tits suisses» (Muesli)... vous savez, riches, blancs et sains ${ }^{43} \ldots$.

«Non je ne mange jamais ici; j'apporte mes sandwiches et je les mange là-bas de l'autre côtét ${ }^{44} »$.

[...] C'est une espèce de lieu exclusif pour les blancs. C'est seulement les noirs branchés qui connaissent cet endroit, et les noirs qui travaillent aux alentours; parce que même les noirs, ils demandent, "vous faites quoi là, c'est quoi cet endroit?»... moi, c'est pas mon genre d'endroit ça, vous savez, moi j'aime... mes amis un peu chauds, vous savez, les gens qui aiment bien brailler un bon coup ou danser, bon, faut qu'on se sente libre - pour pas qu'à chaque fois qu'on fait un truc y ait quelqu'un qui vous... [Il montre un regard furieux] La différence d'âge aussi, je viens juste d'y penser... Pour moi c'est un peu trop excluant ${ }^{45}$.

Bien que ces espaces soient différents, Gandhi Square, Melrose Arch et 44 Stanley Avenue s'adressent à un espace représentationnel typique de la classe moyenne, répondant à une vision planifiée de l'espace. En conséquence, toute la spontanéité qui fait de l'espace public la composante majeure d'une socialité particulière incluant le jeu, le désaccord assumé et l'appropriation vécue de l'espace, se trouve perdue. Le potentiel pour une plus grande inclusivité et un sentiment de solidarité et de care envers l'Autre est tout entier contenu dans cette perte.

\section{Conclusion}

Il est possible qu'en lisant cet article, vous ressentiez tout comme moi un vague sentiment de scepticisme. De fait, si on laissait l'espace représentationnel devenir la forme dominante de définition de l'espace public urbain

41. Entretien avec un ouvrier, 2005.

42. Entretien avec un commerçant, 2005.

43. Entretien avec un commerçant, 2005.

44. Entretien avec un ouvrier, 2005.

45. Entretien avec un ouvrier, 2005. 
simply become unmanaged, decayed and dangerous. Public spaces in Johannesburg have for many years been crime-filled and poorly looked after; places associated with fear rather than urban spontaneity. However, the imported New York style "zero tolerance" approach that the city and its private partners seem to have embraced at great $\cos ^{44}$ and with such vigour is exclusionary and disempowering. This micro-disciplinary style of governance is at odds with an enlarged sense of urban citizenship; the deepening of democracy and the building of a caring society (to use the words of Amos Masondo in his 2008 state of the city speech).

We need to think about what is meant by "tolerance" - the term used in the Growth and Development Strategy. Does tolerance mean that as long as the representational desires of middle-class consumers remain undisturbed, urban others can be tolerated on the peripheries of public spaces, only to be chased away if they become worrisome? Does tolerance mean that spaces should be designed to suit the representational fantasies of the middle classes and be devoid of services for the urban poor? How do we proactively absorb the poor into public spaces through design, interaction, and engagement? How do we make urban public spaces about enhancing a sense of being part of a caring city and serving the representational needs of the urban poor? The only way to really find out is to ensure that public spaces are safe, but in a way which still makes way for representational appropriation, agonistic participation, spontaneous sociality, rest and play.

Teresa Dirsuweit

School of Geography, University of the Witwatersrand, Johannesburg 
à Johannesburg, ce dernier deviendrait tout simplement ingérable, dégradé et dangereux. Les espaces publics à Johannesburg sont depuis de nombreuses années fortement affectés par la criminalité et bien mal entretenus; ce sont des lieux associés désormais à la peur plutôt qu'à la spontanéité urbaine. Pourtant, le modèle new-yorkais importé de "tolérance zéro " que la Ville et ses partenaires privés semblent avoir adopté à grand prix ${ }^{46}$ et avec une grande vigueur, correspond à une approche entraînant exclusion et déresponsabilisation. Ce style micro-disciplinaire de gouvernance ne cadre pas avec un sentiment élargi de citadinité, avec le renforcement de la démocratie et la construction d'une société à visage humain (pour reprendre les mots d'Amos Masondo, le Maire de Johannesburg, dans son discours de 2008 sur l'état de la ville).

Nous devons réfléchir à ce que "tolérance » veut dire, au sens où le mot est employé dans le GDS. La tolérance signifie-t-elle que, tant que les désirs représentationnels des consommateurs de la classe moyenne restent épargnés, l'Autre peut être toléré aux périphéries des espaces publics, mais en être chassé dès qu'il pose problème? La tolérance signifie-t-elle que les espaces doivent être conçus pour répondre aux fantasmes représentationnels de la classe moyenne et n'offrir en revanche aucun service pour les pauvres de la ville? Comment l'urbanisme, l'interaction et l'engagement peuvent-ils aider à intégrer de manière proactive les pauvres dans les espaces publics? Comment fait-on pour que les espaces publics urbains donnent aux gens un sentiment d'appartenance à une ville à visage humain, et servent aussi les besoins représentationnels des pauvres de la ville? La seule manière de trouver la solution est de s'assurer que les espaces publics soient des lieux sûrs, mais d'une manière qui laisse tout à la fois la place à l'appropriation représentationnelle, à une participation fondée sur l'antagonisme, à la sociabilité spontanée, au repos et aux loisirs.

Traduit de l'anglais par Laurent Chauvet

46. Sмiтн Neil, "Global Social Cleansing. Postliberal Revanchism and the Export of Zero Tolerance », op. cit. 



\section{Cultural Appeal as an Argument for Socio-spatial Segregation}

$\mathrm{T}$

HE PURPOSE OF THIS STUDY is to illustrate how culture acts both as an argument for urban improvement and as an evicting agent of "undesirable inhabitants" in the city of Buenos Aires. In fact, certain state-fostered culture cults ${ }^{1}$ arise along with social deterioration and increasingly alarming spatial injustice.

The hypothesis I intend to develop here is that, although it stems from a supposed spirit of universality, the state-driven cultural policy transforms the city into a unique, special place, and consequently, more worthy of socio-spatial segregation processes. In fact, the city can be temporarily "inhabited" for the occasion, but it is not allowed to permanently reside in it unless all the attributes of a good citizen are possessed.

To account for this tension between cultural inclusion and socio-spatial exclusion, I will analyze the case of two villas ${ }^{2}$ which are currently being evicted by the local government to clear land for the development of an open space along the coast of the River Plate, the city's eastern boundary. In fact, the realization of this project depends solely on the eviction of those villas as well as on the displacement of their "undesirable residents".

The most widely spread official policy focuses on attaching green areas to the city coast both to enlarge the Costanera Sur Ecological Reserve and foster luxurious private urbanization projects (in the case of Costanera Sur and Puerto Madero), and also to build a Memorial Park to honour the vic-

1. Delgado Manuel, "Las estrategias de memoria y olvido en la construcción de la identidad urbana: el caso de Barcelona", in Ciudad y Cultura. Memoria, Identidad y Comunicación, Herrera Gómez D. (ed.), Antioquia, Ediciones Universidad de Antioquia, 1998, p. 95-125.

2. Villa, which is similar to a Brazilian favela, refers to precarious settlements of low-income groups with no access to public services. 
tims of Argentina's last military dictatorship, the desaparecidos ${ }^{3}$ (Costanera Norte). Moreover, the local city government has recently submitted this coastal area to UNESCO as candidate to be declared a Cultural Landscape Site. Furthermore, I will explain how these arguments regarding the eviction of these people from emblematic urban areas highlight the cultural advantages that derive from the recovery of such spaces.

In order to understand the reason why the omnipresent appeal to culture acts as a mask for socio-spatial segregation, I will describe how culture regarded as a state-fostered resource - acts as a strategic embellishing instrument ${ }^{4}$. Secondly, I will analyze culture as an excuse for urban development and for the displacement of "undesirable groups" including some of the answers these groups give to the official discourse.

\section{The STRATEGIC EMBELLISHMENT OF THE CITY}

At first glance, Buenos Aires resembles - although, undoubtedly, in a more chaotic way - a warm postcard from a famous story by American science-fiction writer Ursula K. Le Guin called The Ones Who Walk Away from Omelas ${ }^{5}$. In the story, the people from Omelas are enjoying a Summer Festival. There are flying banners, music and colour. The city dwellers are enjoying the show oblivious to any kind of sordidness - they do not know what guilt is - and besides, they do not use swords or have slaves. They are not barbarians, Le Guin remarks, just ordinary people like us.

Buenos Aires official advertising campaign depicts, mutatis mutandis, a similar image of equally divided happiness and lightness: colourful displays

3. The term desaparecidos refers to people who, as a consequence of an official campaign to wipe out supposed left-wing terrorism, were systematically abducted, kept in clandestine detention centres, tortured and then murdered by the 19761983 Military Dictatorship. Their bodies were illegally and secretly reduced to ashes or disposed of to avoid identification.

4. As George Yúdice (Yudice George, El recurso de la cultura. Usos de la cultura en la era global, Barcelona, Editorial Gedisa, 2002) suggests, culture is used as an attraction to foster economic growth and tourism. Culture as a resource entails its management (as different actors make use of it and consider it an essential factor) to promote better social conditions or to encourage economic growth through projects of cultural urban development. Certain influential and powerful groups like the IDB (Inter-American Development Bank), UNESCO, federal and local governments and also businesspeople make use of this resource. Likewise, popular groups resort to culture to increase their social rating based on a number of friendly attributes.

5. Le Guin Ursula K., The Ones Who Walk Away from Omelas, Mankato, Creative Education, 1992. 
highlight Buenos Aires Attitude (Actitud Buenos Aires) or the not less optimistic vernacular web page. Very early every Saturday morning, it is not uncommon to see young people returning from outdoor local government-sponsored concerts. Together with the multiplicity of cultural options offered by different independent theatre companies or self-sponsored artists, the local government also fosters a wide range of dissimilar cultural activities: guided tours to strategically located Buenos Aires ateliers, mural painting by the homeless, or a summer carnival. We can also mention other popular alternatives like The Buenos Aires Tango Festival or the International Festival of Independent cinema. These cultural policies have an alleged universal content: workshops for everybody, art and shows in every corner of the city. Since the year 2000, the local government has been seeking to make Buenos Aires a registered trademark, presenting the city as the Cultural Capital of Latin America ${ }^{6}$.

Private entrepreneurs - generally favoured by the Government - also appeal to culture to promote the distinctive style of their projects. In this sense numerous examples may be provided. It is sufficient to mention important urban requalification processes, such as the ones in Puerto Madero or in Abasto neighbourhood, where, to revert the karma of a deteriorated area, new residential and tourist developments arise in the form of torrescountry ${ }^{7}$, hotels, malls or gastronomic areas with a distinctive cultural seal.

In various important projects - whether private (such as the gated communities or torres-country), public or mixed - the main cultural factor seems to be the eviction of fear. Euphemistically, these projects refer to this condition in terms of security production ${ }^{8}$, which is expressed in private security, surrounding gates or the reduction of potentially dangerous situations such as dark accesses or eventual contact with undesirable neighbours.

If we want to make Buenos Aires even more exotic, colour is by no means less relevant. In more consolidated circuits like $\mathrm{La} B \mathrm{Boca}$, colour expands to

6. This term was coined for the 2003-2007 period of the Culture Plan developed by the Government of the Autonomous City of Buenos Aires.

7. They are gated buildings with 24-hour security and amenities (leisure and sport facilities).

8. In accordance with other authors, Loïc Wacquant (in Giglia Angela, "Espacio público y espacios cerrados en la ciudad de México", in Espacio público y reconstrucción de ciudadanía, Kuri P. Ramírez (coord.), México D.F., FLACSO-Porrúa, 2003) explains how insecurity acts as an umbrella to promote increasingly sophisticated segregation mechanisms. 
new corners of the geography of the neighbourhood, thus symmetrically enhancing it and making it worthy of a visit. The presence of colour outlines the beauty boundaries, the city as a show ${ }^{9}$, and its absence increases the grey of the neighbouring popular groups. For the latter, ignorant of the charms of colour, the neighbourhood remains grey, possibly greyer than before.

Finally, in addition to its main role as a cultural capital, the local government has proposed Buenos Aires as a UNESCO Urban Cultural Landscape Site. The aim of this proposal is to achieve UNESCO's acceptance of coastal Buenos Aires as a World Heritage Site, which, as the Head of Government explains, "will have favourable consequences at different levels, as in the case of tourism, and it will position Buenos Aires in a very important place, thus enhancing our potential capacity to project ourselves in the world ${ }^{10}$ ". The proposed protected area comprises the Costanera Sur Ecological Reserve, Puerto Madero Dams, the historical neighbourhood, Palermo Woods and La Boca, Recoleta and Belgrano neighbourhoods.

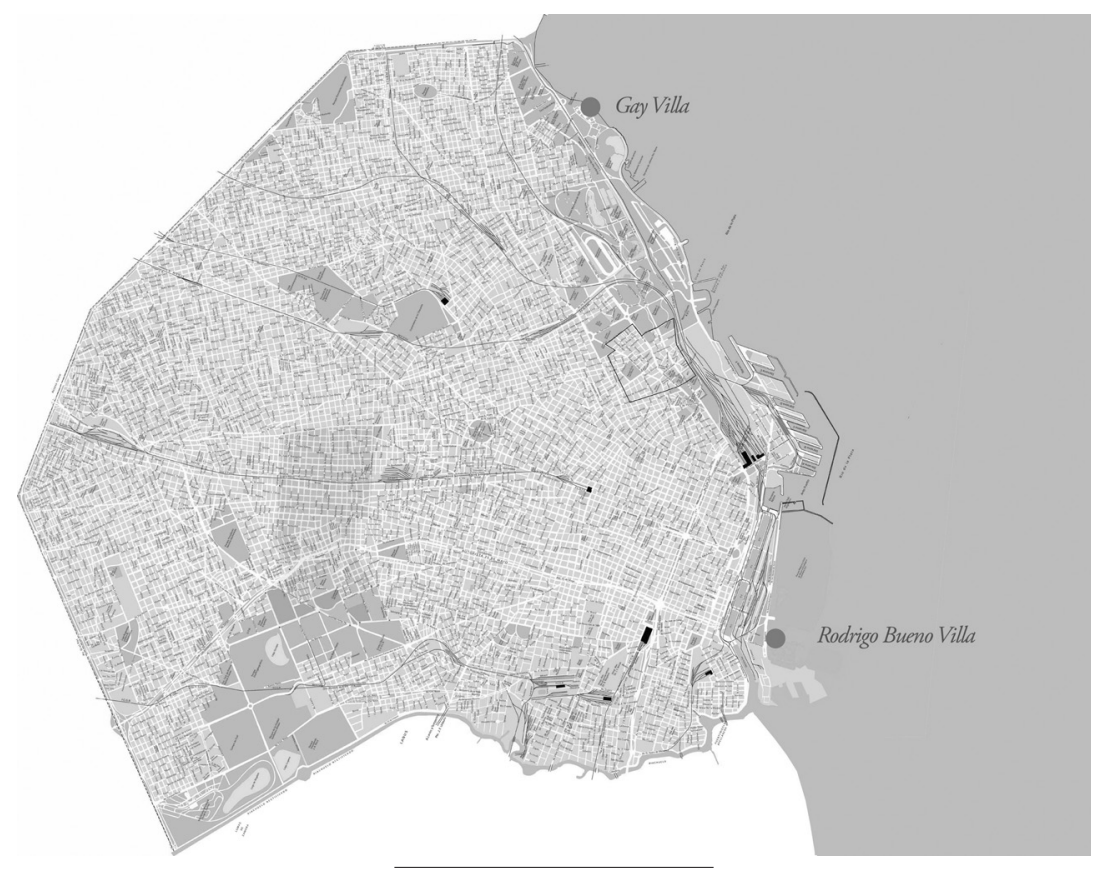

Fig. 1. Buenos Aires City

9. Amendola Giandomenico, La ciudad posmoderna. Magia y miedo de la metrópolis contemporánea, Madrid, Celeste Ediciones, 2000.

10. La Nación Newspaper, 23/3/2007. 
One of the admitted disadvantages underlying these projects is the presence of villas within this coastal area. I will analyze the case of two villas located in this area: villa Rodrigo Bueno and villa Gay. I intend to analyze how culture is used as a resource to set the limits to the legitimate and illegitimate uses of the city.

\section{"A POLLUTION-FREE" SPACE: the CaSe of villa Rodrigo Bueno}

What happens when some two thousand people settle down just a few yards away from one of the most exclusive neighbourhoods in a capital city, and to make matters worse, in a natural reserve? For about twenty years, villa Rodrigo Bueno has survived, invisible, on land gained to the river.

Simultaneously, a brand new neighbourhood called Puerto Madero, which expanded dramatically in the 1990's as the obliged location of Buenos Aires most fancy offices, restaurants and lofts, has today spread to every inch of land worthy of being commercialized. The expansion of Puerto Madero was, in fact, so overriding that it reached the very boundaries of the Ecological Reserve and, consequently, of the villa which was half-hidden among the vegetation. In particular, the construction company IRSA is fostering a 500-million dollar urbanization project on that villa's neighbouring land.

In this place, which can be accessed from the villa by crossing a small stream, they are planning to build a luxurious 11-building gated neighbourhood called Santa María del Plata. However, “...the expansion of the villa - an article ironically points out - is affecting their plans ${ }^{11 "}$. The words of a villa dweller disclose the conflict:

In the past we were ignored and now we are in the limelight. On one side, the reserve, and on the other IRSA. Everything has collapsed. When we realized, this was already a villa in the middle of Puerto Madero...

Juan, 35, Rodrigo Bueno dweller

In fact, the villa was practically ignored until four years ago, when the former director of the Ecological Reserve and the media claimed that its dwellers affected the biodiversity of the Ecological Reserve and prevented the free circulation of different animal species. Therefore, the local government began to articulate the eviction of these popular groups by granting 
subsidies. As a consequence, a high percentage of villa dwellers returned to their homeland or were displaced to the suburbs ${ }^{12}$.

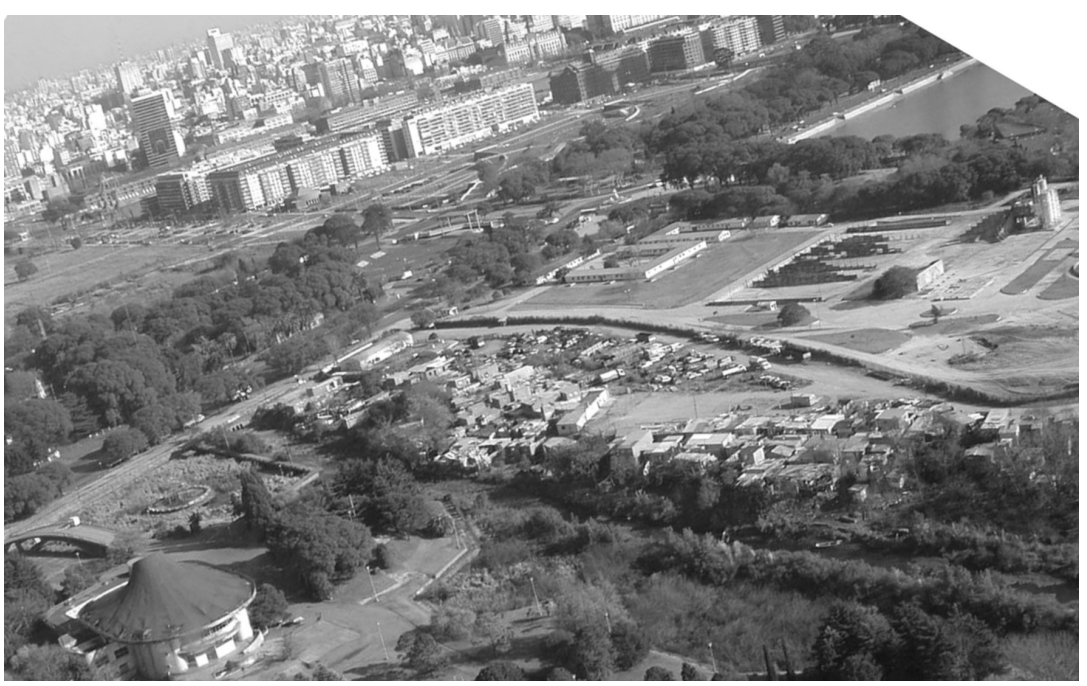

Figure 2

The evicting process included subtle violent mechanisms like the instauration of material barriers with the aim of isolating the villa. Water provision, light, rubbish collection, rat eradication measures and sewage cleaning were also discontinued. Security was placed at the entrance of the villa, and police officers discouraged the entrance of building material and food. Every night, they locked the double gates to discourage new families from coming in. Together with these intimidating measures - which sought to persuade dwellers to leave the place-, the local government built a huge wall just in front of the houses.

...they built a wall from one end to the other. Tourists come from everywhere and so they built a wall and hid poverty. We named it the Berlin Wall. We are still John Does!"

Pedro, 35, Rodrigo Bueno dweller

This testimony combines the issue of the wall with the state-fostered policies which keep dwellers, as so does the wall, "hidden" and with the sensation of "being nobody" since the villa dwellers were continually

12. Owing to a habeas corpus, the eviction of this villa was never completed. Nowadays, many families who had left the villa have returned and many other families have already settled in. 
excluded from assistance or health programmes, or had no access to public services which were available to other city dwellers.

Secondly, symbolic frontiers were also erected since these dwellers were considered impure, contaminating and outside the domain of culture:

A new threat is coming on the Costanera Sur Ecological Reserve [...]. Few people know that within the boundaries of an area of great biodiversity like the one alongside the canal and ceibo ${ }^{13}$ trees therein, more than one thousand and five hundred people have camped for years next to a polluted river, from which they get sick fish and protected coipos ${ }^{14}$ as food. Their urbanization would stop the free circulation of the species between the river and the rest of the reserve, thus affecting the ecosystem and the development of animals ${ }^{15}$.

The only humanity that has been recognized in them seems to be the need to calm down their hunger with sick animals. Would this imply - as Evolutionism advocated a century ago - that certain productions of actors and specific groups do not apparently belong to our truly civilized world? As long as they are considered an archaic group, behind the times or anchored in mere material survival ${ }^{16}$, there is an impossibility to consider them co-citizens since it seems as if they were not, in fact, there. Treated as outmoded remains of a state of nature, what is actually denied to them is their human condition. One of the villa dwellers makes this point clear:

[Regarding different views in favour of the Reserve and against the villa], Animals have more rights than human beings! (She laughs). I think human beings must be given priority, because they are human beings in need.

Ana, 30, villa Rodrigo Bueno dweller

13. Ceibo (erythrina crista-galli) is a kind of tree that grows in many areas in Argentina, specially on the side of rivers and creeks. It can grow 12 meters high. In 1942 the flower of this tree was declared the National Flower of Argentina.

14. Coipo (myocastor coypus) is a widespread rodent in Argentina and South America. It is an excellent swimmer and lives near water. Its meat is edible and its fur is traded.

15. "A New Threat to the Ecological Reserve", an article written by former general director of Costanera Sur Ecological Reserve, in La Nación Newspaper, 2/12/2004.

16. As Johannes Fabian (Fabian Johannes, Time and the other. How Anthropology makes its object, New York, Columbia University Press, 1983) points out, it is better to place "the others" in an almost inaccessible time. This time dilation is regarded by the author as a denial of contemporariness (Mignolo Walter, "La razón postcolonial: herencias coloniales y teorías postcoloniales", in Revista Chilena de Literatura, 47, 1995, p. 91-114). 
In certain exaltations of nature, from this viewpoint, there is a degradation of what is human: the autochthonous wildlife of the reserve would be more akin to the spirit advocated by environmentalists. If culture is defined in terms of opposition to another thing ${ }^{17}$, so could this be alleged with reference to nature. The eviction argument is based on the danger of contamination - and not on the nearby luxurious housing projects - due to the unanimous consensus that ecological preservation is likely to be achieved.

The other unquestionable argument to account for the quest of eviction of the villa is based on the ideal of the recovery of public space. It is averred that the perpetration of a crime - usurpation - violates a right: citizen's use of public space. In this case, it is an argument by extension: in the same way that the villa dwellers damage nature, they so damage public space. Let us examine the decree which arguments the eviction of villa Rodrigo Bueno.

\section{WITNESSETH:}

Whereas $[\ldots]$ such settlement hinders the full development of the Costanera Sur Ecological Reserve, thus negatively impacting on its ecosystem which is of vital importance to the city and its inhabitants;

Whereas, likewise, the latter are prevented from full enjoyment of the abovementioned Reserve due to the existing urban settlement [...]

[And $][\ldots]$ therefore are deprived of their right to a pollution-free environment $[\ldots]$

The Head of Government of the Autonomous City of Buenos Aires declares that:

"A Programme for the Recovery of the Costanera Sur Ecological Reserve shall be created to foster the solution of housing problems that guarantees the eviction of the aforementioned place $[\ldots]^{18}$ ".

There is here, additionally, the reordering of nature as a public place and vested with real property attributes. If the villa dwellers are distinct because they damage nature, heritage and public space, it is the State that presents itself as vulnerable to such threat, which is, "far from being a sign of weakness, a manifestation of strength and it becomes visible in the potentiality of aggression. Only those who are strong can account for the use of violence triggered by vulnerability ${ }^{19}$.

17. Kuper Adam, Cultura. La Versión de los antropólogos, Buenos Aires, Paidós, 2001.

18. Excerpt of Decree number 1247, Government of the Autonomous City of Buenos Aires, August 25, 2005. Highlighted by the author.

19. De Sousa Santos Boaventura, La caída del Ángelus novus, Bogotá, ILSAUniversidad Nacional De Colombia, 2003. 
In this elliptical language of segregation, the "real" city dwellers are the ones who would be affected by the villa. The aim of these Recovery Programmes is focused on the expected effect of full environmental development, or on the joyful enjoyment of certain rightful citizen, which undoubtedly does not include any villa dwellers, who, apparently feed on sick or protected animal species. In this regard, a clear "natural" supremacy of civilization over what is considered uncivilized is constructed ${ }^{20}$.

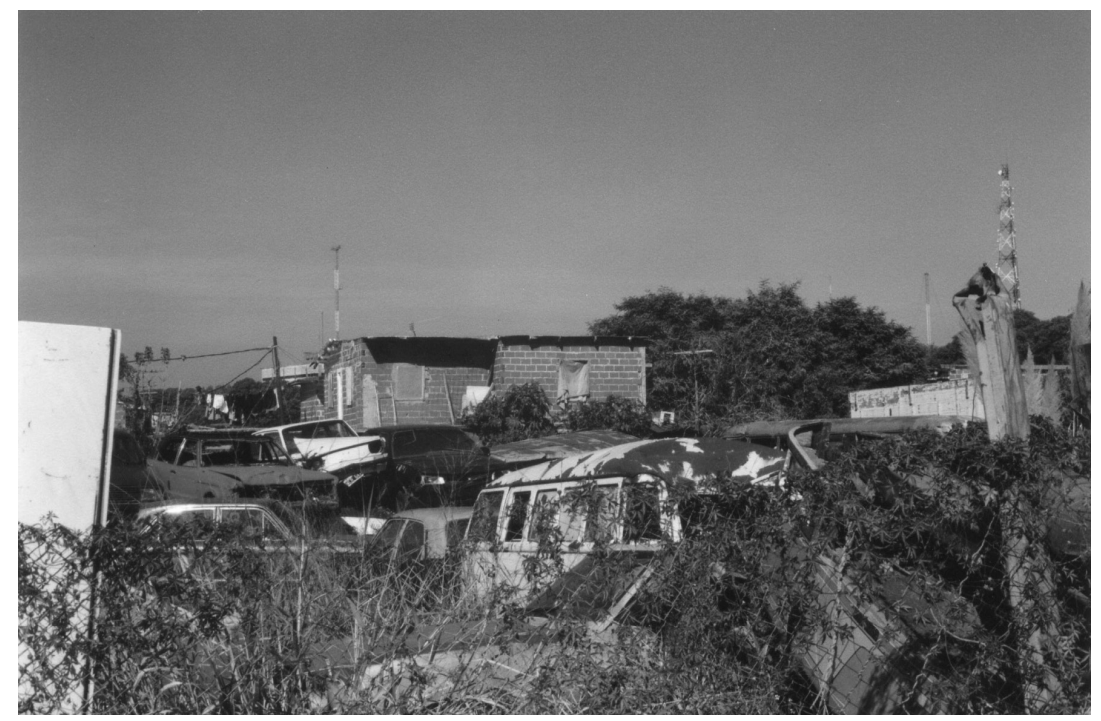

Figure 3

My hypothesis is that the expropriation of the human condition of the villa dwellers operated as an argument to trigger the violence against them. If some dwellers did collaborate to speed their eviction, this was due to the subtle extortion and social inaction that the State produced through, not only the deliberate absence of the provision of services, but also the threats of a potential violent eviction.

In another paper ${ }^{21}$, which cannot be quote in extenso here, I analyzed the statements of the local government in charge of the eviction which announced that if the dwellers refused the monetary subsidy, they would

20. Ibid.

21. Carman María, "Políticas del desamparo: superfluidad y represión", in Revista Ciudades, ${ }^{\circ} 78$, April-June, Puebla, México, Red Nacional de Investigación Urbana, 2008, p. 21-27. 
be evicted by armed police forces. This omnipresent threat was accompanied by similar coercive measures like pulling down the houses of those neighbours who accepted to move, which entailed serious damage to the remaining houses and forced the rest of the neighbours to live among the rubble. Under this complex emotional pressure, which included sleepless adults and children, more dwellers accepted the terms of the negotiation. Forced to play the game imposed by the local government, the villa dwellers were compelled to abandon certain projects - which included community activities - aimed at solving the ongoing problems.

The State, in short, became an active part in the process of weakening social bonds between the inhabitants of the villa, either by negotiating with each person separately or by luring delegates with more money. In accordance with the ideas of a neoliberal State, this policy of expulsion of popular groups from popular areas of the city centre oscillates from assistance to repression ${ }^{22}$.

When these evictions were carried out with notorious violence in the 1990s, it was much easier to object to them due to the illegality of their methods. However, when they allege the recovery of heritage, or the celebration of memory, and the use of explicit violence in the eviction processes is concealed, who would object? When faced with these imbrications of the benefactor side and the expropriator side of the State, it is very difficult to present some resistance. These double bonds - which Pierre Bourdieu (1999: 161-198) characterizes as the right and left hands of the State - are difficult for their own inhabitants to disentangle since these people are accustomed to simultaneously defending and reviling those public officials they deal with every day.

The State is generous, but at the same time, it does much harm. Do you know what it is like to go back to Peru now? Our kids see their houses being pulled down!

Patricia, 36, villa Rodrigo Bueno dweller

Paradoxically, in a democratic context and in a context of a local government which proclaims itself progressive and in favour of the integration of ethnic minorities, it is almost impossible to publicly denounce these discretional practices, whether they are secretly carried out or performed under the complicity of dawn as in the case of the eviction of the homeless form Buenos Aires squares.

22. Grassi Estela, Hintze Susana, Neufeld María Rosa, Políticas sociales. Crisis $y$ ajuste estructural, Buenos Aires, Espacio Editorial, 1994. 


\section{Those Who Violate Rights: THE CASE OF VILLA GAY}

The case of villa Gay offers new aspects to be considered in the issue of how culture may be used to justify the expulsion of popular groups. Located on land gained to the river, villa Gay owes its name to a group of gay cartonero $^{23}$ who lived in the streets. Throughout the years, new families have settled down in this villa to form a permanent population of 90 families.

After these inhabitants were almost totally ignored, besides being compulsively and repeatedly evicted and even sexually assaulted by the police, this villa was finally dismantled in 2006. The central argument that justified said eviction was the need to conclude the Natural Park and Monument to the Victims of State Terrorism, which was being built on these premises, to honour the desaparecidos of the last military dictatorship.

In 2006 the city dwellers and the local government signed an agreement in which the local government would grant monetary subsidies to enable each family to "freely choose" where to buy their house. What was not explicitly stated - and in fact, was completely disregarded by the Government - was that the money given was not sufficient to buy a house. Nevertheless, some people welcomed this subsidy as they viewed this as the only possible alternative to the imminent use of violence.

Either we leave, or the machine pulls down our house. They told us that 100 soldiers would come to clear everything out.

Martín, 50, villa Gay dweller

From an official perspective, however, this course of action was quite successful. Off the record, a Government official admitted that the construction of the coastal park was imposed by law and that the subsidies as well as the lack of information were used as means of extortion.

Information is never clear. It is a strategic resource $[\ldots]$ works are already agreed. But you break an organization...

Local Government official

In effect, neighbours had organized a housing cooperative and there was a project to build a neighbourhood in Greater Buenos Aires: the govern-

23. The term cartoneros refers to the unemployed who earn their living by selling cardboard and other recycling materials they collect from people's rubbish. The number of cartoneros expanded dramatically in the city of Buenos Aires as of the 2001 crisis. 
ment would provide materials, and the neighbours, labour. Some professionals blamed the dwellers for the dismantling of these projects, either by arguing that they lacked education or that gay people were "not sufficiently hard-working" and that each person "gets his due". Considered secondclass citizens, their rights were thus proportional to their "unfinished humanity".

In the official news broadcast at the time of the eviction, the emphasis was placed not on the fate of the displaced families - who were almost ignored - but on the environmental and cultural achievement: the construction of a new corridor next to the river and the realization of the Memory Project. The centre of attention was the clearing of land and on the assurance that those displaced people, by means of a truck provided by the government, would never squat either land or houses in the capital city again.

One paradox is that these Memory spaces which are fostered by Human Rights Organizations directly contradict the resolution of the social rights of the inhabitants of the same city. An official of one of those organizations who was engaged in the realization of the Park manifested that the villa Gay dwellers - cartoneros who lived in precarious houses with no light or water - "violated the rights of their desaparecidos ${ }^{24 "}$. What is cultural is considered, from certain conceptions, an authentic and supreme good, diminishing what is social, which is perceived as superfluous and interchangeable.

\section{ConClusion}

The cases of villa Rodrigo Bueno and villa Gay may evidence how culture can be a master key to obtain political gain, consolidate tourism and position Buenos Aires among the most attractive cites in the world. These two stories further show how cultural appeal accounts for the eviction of groups which are considered undesirable in cosmopolitan Buenos Aires.

Although the eviction of Rodrigo Bueno was based on the exaltation of heritage and, in the case of the villa Gay, the eviction was based on the celebration of memory, they both shared the emphasis on the preservation of nature.

In the preceding cases, it may be assumed that nature functions as a cultural resource. This is not equivalent to stating that which, in fact, is

24. We may wonder whether the forced evictions of those groups would have pleased the desaparecidos of the last military dictatorship, whose memory is honoured in that Park. In many cases, those desaparecidos worked precisely to improve the living conditions of the villa dwellers. 
obvious: that nature is a cultural fabrication, a fabrication produced and reinterpreted considering the actors involved (local government, entrepreneurs, villa dwellers) who seek that their points of view be socially recognized. More specifically, reference is made to the fact that the local government uses nature as an added value in the design of urban projects which celebrate the beauty and uniqueness of the scenery and its cultural privilege.

This statement is relevant in the case of villa Rodrigo Bueno, the survival of which is affected not only because it is part of the Ecological Reserve and this reserve is, in turn, proposed as a UNESCO Cultural Landscape Site, but also because of the real estate development pressure imposed by the nearby booming Puerto Madero neighbourhood. It is also relevant in the case of villa Gay, which was evicted due to the articulation of different interests, among which were the demands of Human Rights Groups for the realization of the Memory Park and those of the Government to finish the Natural Park located next to it, which was regarded as an innovative place for Buenos Aires dwellers and as an "unprecedented urban environmental heritage ${ }^{25}$ ".

In both situations, natural and cultural resources merge in a continuum in which their arguments are mutually reinforced, in order to legitimate certain policies of places ${ }^{26}$ of the city of Buenos Aires. It is no coincidence that the arguments in favour of the eviction of these "undesirable groups" are disclosed together with the unique advantages of these open places, which would be threatened by the sole presence of these people. In the case of the Ecological Reserve, these advantages would be its biodiversity, its recent annexation of new land and its recent inclusion to the list of protected Wetlands.

The reinforcement of our heritage or of our memory is not merely descriptive, but also prescriptive ${ }^{27}$. Those social groups which are regarded as perpetrators of our urban heritage will eventually be "excommunicated" from the capital city and therefore will be deprived of their right to inhabit it.

Paradoxically, these popular groups become subjects only when they perpetrate a threat: the threat that is to damage, impede or hinder the

25. This is one of the statements advocated by The Coast Management Area of the Local Government, which is responsible for the realization of some projects to recycle the coast of the city of Buenos Aires.

26. Delgado Manuel, "Las estrategias de memoria y olvido en la construcción de la identidad urbana: el caso de Barcelona”, op. cit., p. 95-125.

27. Bourdieu Pierre, ¿Qué significa hablar?, Madrid, Ediciones Akal, 1985. 
aura $^{28}$ of nature, our heritage or memory. In this sense, it is not insensible to view as a cultural policy this gesture of discouraging the citizens from the idea that the eviction of the "undesirable groups" constitutes a mere recovery of scenes, always renewed for festivals and idleness. In my view, the official policy concerning the enjoyment of public space - an uninterested, open, festive, democratic policy - renders all the vestiges of state violence unreal.

In effect, the official policy resorts to less visible courses of action, which include not only meagre monetary subsidies to the precarious inhabitants of such lands, but also subtle extortion and threats by public officials to speed the expulsion of those who are considered undesirable.

In short, the appeal to culture on the part of the government in these processes of urban renewal entails a series of effects:

1. It transforms a complex social issue into a mere environmental achievement, and in doing so, it fails to make any reference to the displaced human beings.

2. It dissolves all the violence used in the eviction of these "undesirable groups" and lessens all the conflicts that may arise.

3. It builds a quick consensus around new public places, places which seek to provide a unique experience to the passerby by highlighting the exceptional quality of the heritage, memory and nature.

From what has been exposed, we could hypothesize that urban segregation processes in the city of Buenos Aires comprise at least four essential dimensions:

1. A silent segregation, expressed in the displacement of groups considered unworthy of the capital city. The paradox is that these silent eviction policies are difficult to denounce in a context of a self-proclaimed progressive State which is in favour of democratic and multicultural integration.

2. An aggravated segregation, as many popular groups were already violently ousted from the city during the last military dictatorship (19761983) and through illegal eviction during the 1990s. In this sense, these

28. I refer to the widely-spread conception of aura by Walter Benjamin (1980, in Castilla Urbano Francisco, "Moral y elitismo: la concepción de la cultura de Walter Benjamín", in La ciudad es para ti. Nuevas y viejas tradiciones en ámbitos urbanos, Ortiz García Carmen (dir.), Barcelona, Editorial Anthropos, 2004, p.325-347), which becomes particularly appropriate to describe nature as the object of artistic contemplation: its plenitude and authenticity, its mystery which renders it impossible to embrace. 
new eviction policies reinforce the unwritten rules that govern the legitimate and illegitimate use of urban space and they also disclose the relation of these popular groups with the state and their troublesome permanence in the capital city.

3. A default segregation, which arises as a consequence of an omission policy expressed in the absence of housing policies for popular groups, even in a city with a significant surplus ${ }^{29}$.

4. An alleged positive or indolent segregation, which manifests itself in the process of self-segregation of the higher classes, both in the torrescountry in the centre of the capital city and in the suburban gated communities. In fact, each eviction of "undesirable groups" from prestigious neighbourhoods consolidates, simultaneously, the splintering urbanism ${ }^{30}$ or the desired homogeneity of certain emblematic neighbourhoods.

With reference to what has been previously exposed, this policy concerning the displacement of low-income groups from the city's most prestigious areas may be explained in terms of spatial injustice since it not only deepens the current socio-urban segregation process, but also discloses an authoritarian viewpoint with regard to which social groups deserve to live in the heart of the city of Buenos Aires, the alleged Cultural Capital of Latin America. Is there not, in fact, a deliberate obliviousness production policy of those who involuntarily offer their hard daily existence? I refer to those people who live in squares or garbage dumps, in squatted houses, alongside

29. The cultural urban management becomes visible in its complex articulation with schizopolicy (CARMAN María, "Usinas de miedo y esquizopolíticas en Buenos Aires", in AIBR, Revista de Antropología Iberoamericana, vol. 3, n 3, SeptemberDecember 2008b, p. 398-418), which undoubtedly complements the hegemonic logic about the ways to inhabit and to stay in the city. In another paper (CARMAN María, Ibid.), I identified three types of coercive policies arising from the erratic urban policies directed to popular groups in Buenos Aires, which were implemented in the last decades. Firstly, there is the omission policy, which contributed to build the city even more intensively than the policies which were effectively implemented. Secondly, in the excess policies, I state that those illegal dwellers receive an equally illegal response from the State as in the case of the illegal forced evictions. Finally, while analyzing the excess and omission policies, I came across a wide range of contradictory practices with respect to the level of official intolerance towards popular groups, which I named schizopolicies. The reference to the delirium as being social and political is not my production; neither is the articulation between capitalism and schizophrenia, which is explained by Gilles Deleuze and Félix Guattari in The AntiEdipous (1982 [1972]).

30. Donzelot Jacques, "La nouvelle question urbaine", in Esprit, vol. 11, n 258, Paris, 1999, p. 87-114. 
rivers or in precarious villas, "those who are mentioned (if not exclusively) when they cause problems ${ }^{31 "}$.

We know that the State contributes in a number of different ways, as Bourdieu ${ }^{32}$ suggests, to the unification of cultural and symbolic space. One of those ways is the concentration and monopolization of a legitimate lifestyle, the counterpart of which is the discredit of different lifestyles which are "abandoned to savagery or vulgarity"3". Another possible way is the authoritarian organization of urban space ${ }^{34}$ and the control of the cultural management of the resistance. Although the State highlights the sociocultural diversity, at the same time, it sets limits to show how this diversity could be presented and represented. On the other hand, certain practices and expressions arising from low-income groups that cannot be reabsorbed by the logic of the State are likely to be displaced from the city, yet, at the same time, these groups can be granted certain rights. It is a mutual formative struggle, or rather, in other words, a dialectics of cultural struggle against a project of domination ${ }^{35}$.

From an anthropological viewpoint, it is essential to consider which concepts of public space underlie these land depuration practices ${ }^{36}$. Who should have access to public space and who should not? For whom should this space be organized and who should have the right to use it? We must remember that we, anthropologists, are co-citizens of these so-called undesirable groups and our discipline discourages the very concept of segregation $^{37}$. These are two reasons, among hundreds of others, which should encourage us to leave behind our endogamy and take an active part in the

31. Bourdieu Pierre, La miseria del mundo, Buenos Aires, Fondo de Cultura Económica, 1999.

32. Bourdieu Pierre, Las estructuras sociales de la economía, Buenos Aires, Ediciones Manantial, 2001.

33. Ibid.

34. Delgado Manuel, "Las estrategias de memoria y olvido en la construcción de la identidad urbana: el caso de Barcelona”, op. cit., p. 95-125.

35. Hall, in Levinson Bradley, Todos somos iguales. Cultura y aspiración estudiantil en una escuela secundaria mexicana, México D.F, Santillana, 2002, p. 387-422.

36. Delgado Manuel, "Las estrategias de memoria y olvido en la construcción de la identidad urbana: el caso de Barcelona”, op. cit., p. 95-125.

37. Bernard Carmen, "Ségrégation et anthropologie, anthropologie de la ségrégation. Quelques éléments de réflexion”, in La ségrégation dans la ville, Paris, L’Harmattan, 1994, p. 73-84. 
public debate by denouncing those sugary words and subtle practices of contemporary segregation.

María CARMan

University of Buenos Aires, CONICET (Argentine National Council of Scientific and Technological Research)

Translated from Spanish by Maria Celeste Irace 



\section{Ecological Gentrification: Re-negotiating Justice in the City}

I N THIS воOK on Justice and Segregation, I want to return to David Harvey's book Justice, Nature \& the Geography of Difference, in which he challenged scholars to explore the spatial and political forces that produce the convergence of environmental and social phenomena. Harvey called for collapsing the boundaries between social and natural through recognizing human impacts on ecosystem functioning. He also advocated incorporating ecological processes into understanding the transformation of social processes within urban spaces ${ }^{1}$. As a dialectical thinker, Harvey paid attention to the complex relationships in urban spaces that planning practice and research conceptualizes as less complex and more discrete phenomena. He was and remains critical of planning's narrow approach to urbanization, and argued that planning research fails to rigorously engage the dialectics of social and environmental change in urban areas. My work responds to David Harvey's challenge to develop a concept which captures the spatial and political complexities operating in urban environments, and which brings together social and ecological understandings of urban change.

There are three goals for this paper. My first goal is to demonstrate tensions between notions of home articulated by homeless individuals in urban green spaces and definitions of homeless and green space articulated by policy makers currently involved in developing policies aimed at ending homelessness. I apply the analytic notion of bare life ${ }^{2}$ to capture the political consequences for homeless individuals encountering the ideologies of policy makers, planners, and law enforcement. Bare life reveals the ways in which juridical notions of power, exercised by policy makers, planners and

1. Harvey David, Justice, Nature and the Geography of Difference, Oxford, Blackwell Publishing, 1996.

2. Agamben Giorgio, Homo Sacer: Sovereign Power and Bare Life, Daniel HellerRoazen (trans.), Stanford, CA, Stanford University Press, 1998. 
law enforcement work in concert to keep individuals vulnerable to the discretionary application of law absent full legal protections ${ }^{3}$. At its core, bare life captures the dialectics between politically and culturally contingent notions of home, homelessness, and green space; and reveals the consequences of enforcing these notions of homeless and green spaces upon the lives of homeless individuals who lack private places while permitted to be nowhere publicly.

The second goal of the paper is the presentation of a concept that reveals the complexity and specificity of how social and environmental processes are inter-related. I define ecological gentrification as the displacement of vulnerable human inhabitants resulting from the implementation of an environmental agenda driven by an environmental ethic. Ecological gentrification captures the consequences of narrow planning approaches that fail to recognize the connectively among housing, homelessness, and urban green spaces. As the city parks department sets aside land based on ecological values and natural amenities, homeless individuals who live in these same green spaces because they consider all other options afforded not viable are forced to either move or remain illegally, thus risking incarceration. It is in these urban green spaces where social and ecological processes encounter each other in unanticipated ways, and where a concept is needed to capture this unfolding complexity.

I conclude by advocating a robust pluralism of home and green spaces as an initial movement towards re-negotiating concepts of justice in urban areas. I present strategies for resisting the production of bare life with the goal of improving the lives of homeless people, and argue that such strategies require integrating environmental and social planning agendas.

Previous scholarship has focused on articulations of home by homeless people using shelters ${ }^{4}$, residing in squats ${ }^{5}$, and living on the

\section{Ibid.}

4. Desjarlais Robert, Shelter Blues: Sanity and selfhood among the homeless, Philadelphia, PA, University of Pennsylvania Press, 1997; Rivlin Leanne, "The significance of home and homelessness", in Marriage and Family Review, vol. 15, n ${ }^{\circ}$, 1990, p. 39-56.

5. Rivlin Leanne, Імвімво Jeanne, "Self-help efforts in a squatter community: Implications for addressing contemporary homelessness", in American Journal of Community Psychology, vol. 177, nº 6, 1989, p. 705-728; Moore Jeanne, Canter David, Stockley Des, Drake Madeline, The Faces of Homelessness in London, Aldershoot, Dartmouth, 1995. 
streets $^{6}$. Constructions and perceptions of home have been related to identity $^{7}$, to types of residences ${ }^{8}$, and to spatial movement patterns and social networks ${ }^{9}$. Much of this work has documented the similarity between homeless and housed people's construction of home; while other work has demonstrated how concepts of shelter influence the types of accommodations provided by the social service industry. My research builds on this previous work, beginning with the recognition that presenting notions of home among homeless individuals documents how that which is most familiar - home - informs that which is least familiar being homeless. In addition, I analyze how seemingly disparate concepts - home, homelessness, and green spaces - are involved in urban homelessness, and how policy makers and planners fail to recognize these connections. The decision made by homeless individuals to live in urban green spaces points to the specific ways in which homeless people are precisely managed by the social service system, the city parks department and law enforcement. In order to fully understand the complexities of homelessness, which includes the experiences of being homeless, and the political and cultural constructions of homelessness as a policy and planning issue, it is necessary to articulate the ideologies operating in concert producing bare life for homeless individuals.

6. Rowe Stacey, Wolch Jennifer, "Social networks in time and space: Homeless women in Skid Row, Los Angeles", in Annals of the Association of American Geographers, vol. 80, n 2, 1990, p. 184-205; Desjarlais Robert, Shelter Blues: Sanity and selfhood among the homeless, op cit.; MAY Jon, "Of nomads and vagrants: Homelessness and narratives of home as place", in Environment and Planning D: Society and Space, vol. 18, 2000, p. 737-759; Sсотт Susan, All our sisters: Stories of homeless women in Canada, Ontario, Canada, Broadview Press, 2007.

7. Rowe Stacey, Wolch Jennifer, "Social networks in time and space: Homeless women in Skid Row, Los Angeles”, op. cit.; Sсотт Susan, All our sisters: Stories of homeless women in Canada, op. cit.

8. Watson Sophie, Austerberry Helen, Housing and homelessness: A feminist perspective, London, Routledge and Kegan Paul, 1986; Veness April, "Home and homelessness in the United States: Changing ideals and realities", in Environment and Planning D: Society and Space, vol. 10, 1992, p. 468-493; Tomas Annabel, DitTMAR Helga, "The experience of homeless women: An exploration of housing histories and meanings of home", in Housing Studies, vol. 10, 1995, p. 468-493.

9. Rowe Stacey, Wolch Jennifer, "Social networks in time and space: Homeless women in Skid Row, Los Angeles", op. cit.; MAY Jon, "Of nomads and vagrants: Homelessness and narratives of home as place", op. cit. 


\section{Theoretical Framework: Bare Life}

I want to begin by reviewing Giorgio Agamben's notion of bare life ${ }^{10}$, which I leverage to more precisely reveal how homelessness, motivated by specific notions of home and green spaces, is constructed by policy makers and planners. Echoing Feldman ${ }^{11}$ and Kathleen Arnold ${ }^{12}$, I argue that bare life is a useful analytic framework for understanding that homelessness is related to more than the economics of affordable housing; that is it more than a psycho-medical problem focused on individuals' addiction and mental illness. Homelessness is a deeply political problem tied closely to concepts of housing and shelter, and to the legitimized values and uses of housing and green spaces. The politics of homelessness are informed by relationships between politically and culturally contingent notions of home and homelessness, and requires an analytic framework that reveals the confluences of ideological categories within juridical and institutional systems in order to articulate the consequences of these categorical constructions on the lives of those being categorized.

Giorgio Agamben premises the concept of bare life upon the exercise of sovereign power, defined as "... the legal power to suspend the validity of the law, legally [placing] himself outside the law ${ }^{13}$ ". The suspension of the juridical order results in a state of exception, where people are denied protection from the law while remaining vulnerable to discrimination and violence. These individuals are known as homo sacer, a term Agamben retrieves from Roman times to describe individuals capable of being murdered without accountability. People categorized as homo sacer live ambiguous and vulnerable lives, where they are included in society by exercises of juridical power that exclude, expel and erase them from urban society. Agamben refers to this as "the ban", in which vulnerable human lives are included as members of society through the management of their daily existences via a suite of arbitrarily enforced ordinances motivated by specific conceptions of what constitutes a legitimate citizen - and in the case of homeless individuals, motivated by specific conceptions of housing, shelter, homeless, and green spaces. However, this inclusion ultimately excludes homeless people - spatially, legally, and culturally - from other urban (housed) resi-

10. Agamben Giorgio, Homo Sacer: Sovereign Power and Bare Life, op. cit.

11. Feldman Leonard, Citizens Without Shelter: Homelessness, Democracy, and Political Exclusion, City, Cornell University Press, 2006.

12. Arnold Kathleen, Homelessness, Citizenship, and Identity: The Uncanniness of Late Modernity, Albany (NY), State University Press of New York, 2004.

13. Agamben Giorgio, Homo Sacer: Sovereign Power and Bare Life, op. cit., p. 15. 
dents and spaces. The ban emphasizes the ambiguous relationship between insider/outsider; between legal citizen/illegal refugee; between protection/ violence. It is this zone of indistinction, where juridical protection and violence becomes undifferentiated, that characterizes Seattle's approach to urban homelessness.

The challenge in applying the concepts of bare life and sovereign power resides in their abstract qualities; and recent critiques of Agamben's work point to this ${ }^{14}$. Agamben's idea of sovereign power is not explicitly attached to a tangible institutional body or set of human-scaled relationships involved in the everyday lives of people ${ }^{15}$. Rather, the state persists as a pervasive homogenous regulating entity, elusive and powerful in its ability to render decisions regarding the applicability of law. However, the exercise and experience of sovereign power is not faceless. Although Agamben does not define the multiplicity of institutions and actors who exercise sovereign power, I argue that sovereign power is exercised not only by policy makers and planning administrators, but also by front line workers in government and social service agencies who routinely interact with homeless individuals. Integrating the work of Michael Lipsky ${ }^{16}$, I argue that homeless people interact directly with those who possess discretionary power to decide when and how to enforce the law, who grant or deny access to a shelter, or choose when to incarcerate individuals for violating anti-camping ordinances. Each encounter is an exercise of juridical and institutional power that ultimately contributes to the bare life existence of homeless people.

\section{Notions of Home \\ Among Homeless Individuals}

In this section, I present notions of home as articulated by homeless people living in urban green spaces. These vignettes are from currently and formerly homeless individuals interviewed for my doctoral research ${ }^{17}$. I

14. Laclau Ernesto, "Bare life or social indeterminacy?", in Giorgio Agamben: Sovereignty and Life, Calarco M., DeCaroli S. (dir.), Stanford (California), Stanford University Press, 2007.

15. Agamben Giorgio, Homo Sacer: Sovereign Power and Bare Life, op. cit.

16. Lipsky Michael, Street-level Bureaucracy: Dilemmas of the Individual in Public Services, New York, Russell Sage Foundation, 1980.

17. My doctoral research is a case study that describes the disconnections between notions of home as articulated by homeless adults and ideological notions of home and homeless espoused by government agencies, local social service administrators, housing advocates, and policy makers, and provides recommendations for reconci- 
have chosen these particular stories because they highlight the experiences of bare life, while also being representative of those who decide to live outside.

David. David is 50 years old and lived on the streets for almost 19 years. He walked away from an oil rig job in Louisiana because he was unable to pay property taxes, and hopped a freight train to Chicago and then Seattle. Upon arriving in Seattle, he began living in a homeless camp with 15 other people. While he worked day laborer jobs, either as a construction or landscape worker, the other campers would watch his belongings and take care of the common space. The camp survived on food from food banks and tolerated wet, cold winters with donated blankets and tents. Despite these hardships, David describes this camp as the only type of family he has ever known. He says: "Your word was your bond in the camp. It was very organized and dependable. It was just a good feeling." Due to increased violence on the streets that targeted his camp, and because the land was purchased by the city parks department for the construction of a new urban green space, most of the campers, including David, moved inside. The active and supportive network was spatially dispersed, and with the former campers housed in various single room occupancy hotels throughout the city, David has not been able to maintain close connections. Now, living inside, David considers himself homeless. That is, for David home is a sense of belonging to a group of people that care for each other and share a common space.

Michael. Michael is 43 years old who was homeless from adolescence until his early forties. In his words, he says: "At 14 years old, I voiced to the system: the abuse needs to stop here. I want to be set free from the system of abusive adults." Upon legal emancipation, which he achieved with the help of a prostitute and drug dealer, he lived on the streets along the west coast. He claims that living on the streets stabilized his traumatized psyche. He lived under a highway for eight years in a wooded camp site; he got his food from dumpsters; he went without taking showers for years; and remained a loner, working through the intense anger, betrayal and confusion that resulted from extreme childhood abuse. Michael slowly learned to enter into relationships with street people. He worked with a community psychiatrist who allowed him to holler out his anger. Michael says: "He let me reconstruct the human being in me." For Michael, home was a landscape

ling these disconnections. I combined semi-structured interviews with 80 homeless individuals and 20 policy makers, with multi-sited participant and direct observations conducted in three agencies in policy development meetings associated with Seattle's Ten Year Plan to End Homelessness. 
that was large enough to contain his overwhelming grief and rage while he recovered himself. Home, as a childhood place, was associated with pain and terror, and until his psychological trauma was processed, Michael could not be at home contained by four walls. Instead, home was a process of reconstructing and recovering a sense of himself. It was only after recovering a strong sense of his personhood that Michael was able to move into a single room occupancy hotel, where he has lived for the past five years.

Pablo. Pablo is 20 years old. Born in Columbia, he has been homeless for two years, arriving in Seattle from Florida where he was episodically employed. He sells and uses marijuana, and works as a day laborer to earn enough money for food, coffee, and pot. He lives in an urban green space that is adjacent to a city park in a wealthy neighborhood. Pablo decided to live outside to heal lung damage he sustained while working in Florida. The green space he lives in holds 30 camps during the wet winters and roughly 150 camps in the summer. Entrances to the camps along the perimeter are concealed by brush strategically placed by campers, yet Pablo fears being detected by local residents and park users when he returns to his camp site at the end of a work day. While camping in the green space is prohibited, the parks department and police are aware of the camps, and allow campers to reside until a neighborhood resident complains; then the parks department begins to sweep the camps out. So far, Pablo's camp site has not been detected. Despite minimal camaraderie between camps, Pablo has made connections with some of the longer term residents. In the summer they pool money for beer and combine food stamps for grilling meat. The majority of time Pablo works as a day laborer, and when not working, he reads about cosmology and explores his connections to nature. For Pablo, home is the privacy of the camp where he can heal his body, connect to nature, and develop friendships.

Mel. Mel is a 61 year old Native American who has lived outside for 15 years. He ran away from his home on a Minnesota reservation when he was 15 years old. He worked for the Canadian railroad for a few years, and then spent 20 years building log cabins. He tried living in a single room occupancy hotel but was disoriented by the quiet and absence of his friends. The schedules, rules, and expectations associated with the shelters are not compatible with his desires for autonomy and freedom. Mel has a legal eviction on his record, and he occasionally pools money with friends for hotel rooms during the rainy season. For Mel, home is not defined by four walls, and includes places in the city where he and his friends congregate to socialize and sleep. He notes that there are fewer places where he can camp now, and he has been jailed for sleeping in parks and green spaces. He says: "I am 
homeless because it's the way I like it. People ask me where I live and I say - over there and over there. I drink when I want to and I move around when I want to." Mel's notion of home is also related to specific cosmology that embraces a physical and spiritual intimacy with the natural landscape, even in an urban area. For Mel, home is located in a landscape steeped in a cosmology that prefers the openness of the urban environment despite threats of incarceration.

To summarize, the notions of home articulated by the four individuals presented here include: autonomy (defined as management of self by self), freedom, a sense of belonging to a community, the recovery of oneself, healing oneself in nature, and dwelling not bounded by walls. Some of these notions of home reflect aspects of home (autonomy, freedom, belonging) articulated by traditionally housed individuals ${ }^{18}$. Other notions of home (healing in nature, dwelling not bounded by walls) challenge societal, governmental, and institutional conceptions of the legitimate home as a structure with four walls, where nature and the built environment are clearly distinct. What is striking is how the four conceptions of home presented here, and the strategies these homeless individuals practice to obtain, sustain, and occasionally lose, strategies for being-at-home, challenge the legitimized concepts of shelter and housing that drive current policy development efforts aimed at ending homelessness.

It is important to recognize that I am not romanticizing homeless people's lives in urban green spaces; I am not advocating that homeless people take up permanent residence in urban green spaces as a strategy for alleviating homelessness. No one should be forced to sleep outside as a last resort. What I am emphasizing is that the options afforded homeless individuals are not viable. Homeless individuals I interviewed experience shelters as spaces of violence and crime, requiring a constant vigilance, where programs and meals are often linked to a religious agenda that they experience as insulting or alienating. Single room occupancy hotels are described as places of surveillance with monthly cleaning inspections, places where an active drug culture persists. All of these environmental factors threaten the sense of freedom, autonomy and dignity, and an alignment with a cosmological orientation (like Native American spirituality that embraces direct connections with the biophysical landscape) central to

18. Dovey Kim, "Home and homelessness", in Home Environments, Altman I. and Werner C. (dir.), New York and London, Plenum Press, 1985, p. 33-61; MARCus Cooper Clare, House as a Mirror of Self: Exploring the Deeper Meaning of Home, Berkeley (CA), Conari Press, 1995. 
how these individuals want to live. In response to these environmental factors, some homeless individuals opt to camp in urban green spaces precisely because in these spaces they can achieve desired qualities of home. Their decision to camp outside is not an absolute preference; rather, it is a choice made relative to the viability of all other options.

\section{Policy Context}

These decisions of individuals to sleep outside are made as policies aimed at ending homelessness are currently being developed in Seattle. Although Seattle's homeless population constitutes less than one percent of the total population ${ }^{19}$, this remains a highly visible group of people, partly in response to the federal initiative to end homelessness ${ }^{20}$. Seattle, like over 290 communities in the United States, is in the process of developing what is referred to as The Ten Year Plan to End Homelessness. The U.S. Department of Housing and Urban Development [HUD] has mandated that Ten Year Plans be developed by communities in order to receive HUD money for homeless services. HUD rationalizes the local approach to policy development by claiming homelessness varies locally, and consequently effective strategies to 'end homelessness' need to be developed locally. The role of HUD in the development of ten year plans is primarily facilitative, providing technical expertise to local policy development groups. Critics of HUD's Ten Year Plan to End Homelessness initiative assert that HUD is devolving its responsibility for creating a national housing strategy, and, with concurrent budget cuts in housing voucher programs and homeless services funds, critics assert that HUD is setting up local policy development efforts to fail through lack of adequate funding ${ }^{21}$.

19. Seattle/King County Coalition for the Homeless, The 2004 Annual One Night Count: People Surviving Homelessness in King County, Washington, Seattle, WA, Seattle/King County Coalition for the Homeless, 2006.

20. In 2000, the National Alliance to End Homelessness (NAEH) published $A$ Plan, Not A Dream: How to End Homelessness in Ten Years (Washington, D.C., 2000). NAEH defined four strategies: collect local data; implement a housing first strategy; prevent individuals from becoming homeless; and integrate employment, housing, and services into building the infrastructure to end homelessness. In 2001, the U.S. Department of Housing and Urban Development endorsed ending chronic homelessness in ten years; and in 2002 the U.S. Interagency Council on Homelessness was re-activated.

21. Western Regional Advocacy Regional Project, Without Housing: Decades of Federal Housing Cutbacks, Massive Homelessness, and Policy Failures, San Francisco, CA., 2006. 
HUD categorizes homeless individuals based on the amount of time spent homeless and the places used for sleeping. A chronically homeless person is a person who has been continually homeless for a year or more, or at least four times in the past year. A non-chronically homeless individual is defined as:

a person sleeping in a place not meant for human habitation (i.e., on the streets, parks, cars), residing in emergency shelter, transitional housing, or supportive housing. Also someone being discharged from an institution without subsequent residence identified and lacking the resources and support networks needed to obtain access to housing ${ }^{22}$.

On the one hand, alleys, parks and cars are not designed for sleeping, urinating, and having sex; in this sense, these spaces are not designed for human habitation, if habitation is equivalent to human dwelling. Yet, these spaces are occupied by people who are creating living in parks and green spaces because the options afforded them are not considered viable. HUD's de-legitimization of homeless peoples' strategies for acquiring qualities of home in green spaces reflects the adherence to an ideologically constructed notion of home. In classifying a person homeless based on sleeping in a park (and implied is sleeping in greens spaces), HUD implies that legitimate housing of homeless individuals requires four walls, separated from nature and an occupant who is clean and sober. In addition, HUD defines people who live in transitional and supportive housing also as homeless. Taken together, HUD's definitions of a homeless person reflect the imposition of a legitimate home upon a group of people who, for a variety of reasons, are not able to, or choose not to, secure a legitimate home. Instead, what these people are offered, including shelters and transitional housing, is not perceived or categorized as a home at all by policy makers and planners. Individuals living in green spaces are consequently considered lacking the very thing (home) that they are seeking to maintain. Such irony is a fundamental experience of bare life for homeless individuals.

While the occupation of green places designates occupants homeless according to HUD, the police department considers such individuals in violation of anti-camping ordinances. In 1993, the city attorney proposed and citizens passed a series of ordinances that regulate behavior in public spaces, making it illegal to sit and lie down on sidewalks during certain

22. United States Housing and Urban Development Agency, Shelter Plus Care Manual (Section 2.2), 2006, http://www.hud.gov/offices/cpd/homeless/library/ spc/resourcemanual/, no page numbers. 
hours, to urinate and drink in public, and to camp in public parks ${ }^{23}$. Other scholars have argued that these ordinances reflect political economic agendas developed by political and business elites, which are enforced to produce sanitized and safe spaces of consumption that ultimately criminalizes homeless people $e^{24}$. I expand this critique by arguing that the anti-camping ordinance, in particular, reflects an ideological notion of what constitutes legitimate use of green space, now appropriated to serve an ecological agenda that ignores the connections between notions of green space, home, and homelessness.

Seattle is known as the Emerald City and the Seattle Department of Parks and Recreation (SPRD) manages parkland representing approximately $9 \%$ of the city land area ${ }^{25}$. The political context in which city parks are managed and designated has changed in response to an increasingly urban and densely populated landscape that embraces a distinct environmental consciousness ${ }^{26}$. Beginning in 2000, SPRD broadened their management goals and embraced a more ecologically oriented strategy for parks, and created its first Urban Wildlife and Habitat Management Plan in response to citizens who expressed their desire "to have wildlife as an integral part of

23. In 1993 Seattle City Council approved a series of ordinances known as the Civility Ordinances (Gibson Timothy, Securing the Spectacular City: The Politics of Revitalization and Homelessness in Downtown Seattle, New York (NY), Lexington Books, 2004). The no-sitting ordinance prohibits sitting on any sidewalk between 7:00am and 9:00pm, and carries a 50 dollars fine and possible incarceration (BAss Sandra, "Negotiating change: Community organizations and the politics of policing", in Urban Affairs Review, vol. 36, n' 2, 2000, p. 148-177). In 1997, City Council approved a parks exclusion ordinance in response to complaints that parks were becoming homeless camp sites. Individuals caught drinking, camping, or committing "acts of misbehavior" are banned from parks. Individuals with repeat violations can be banned from parks by police for up to one year (ibid.).

24. WALDRON Jeremy, "Homelessness and the Issue of Freedom", in UCLA Law Review, vol. 39, 1991, p. 295-324; MArin Peter, "Helping and Hating the Homeless", in Harper's Magazine, January 7, 1987, p. 310-318; Mitchell Don, The Right to the City: Social Justice and the Fight for Public Space, London, Guilford Press, 2003; Arnold Kathleen, Homelessness, Citizenship, and Identity..., op. cit.; Feldman Leonard, Citizens Without Shelter..., op. cit.

25. Seattle Parks and Recreation Department, Seattle Parks and Recreation 2006 Development Plan, Seattle (WA), 2006; Dooling Sarah, Simon Gregory, Yocom Ken, "Place-Based Urban Ecology: A Century of Park Planning in Seattle", in Urban Ecosystems, vol. 9, N4, 2006, p. 299-321.

26. Ibid. 
the city ${ }^{27}$.' It was during this time green space became a designated category of park property, defined as land set aside to protect natural amenities and ecological functioning ${ }^{28}$.

Yet these are also the places where Pablo lives; where Mel drinks with his friends; and where Michael and David used to live. The parks department definition of green spaces excludes the occupation by homeless people; homeless people are also expelled if detected through the enforcement of the anti-camping ordinance. These are markers of bare life, where homeless people are included in society through active exclusion, expulsion, and erasure. But this is an old story.

\section{ECological Gentrification}

Here is the new story unfolding in Seattle: that an espoused environmental ethic is also involved in the production of bare life for homeless people. I refer to this concept as ecological gentrification, and define it as the displacement of vulnerable human inhabitants resulting from an implemented environmental agenda driven by a totalizing environmental ethic. Ecological gentrification captures the complex dialectics involved in the transformation of urban environments; specifically it integrates the relationships involved in the production of bare life for homeless people which conventionally have been treated discretely, or integrated in limited ways, by policymakers and planners.

There are two recent examples of ecological gentrification in Seattle. The first example is the largest city funded ecological restoration of an urban salmon-bearing stream. In 2000, as part of the site preparation, the city cleared out homeless people who occupied the site adjacent to the $\mathrm{creek}^{29}$. With the construction of a public trail and the improved aesthetics of the stream, the site is now monitored to ensure homeless people remain excluded. The second example was a recent public design charette which invited housed citizens to plan future green spaces over the next 100 years to create an ecologically sustainable city through the construction of green

27. Seattle Parks and Recreation Department, Urban Wildlife and Habitat Management Plan: 2000 Update, Prepared by Greg Miller, Seattle, Washington, 2000.

28. Dooling Sarah, Simon Gregory, Yocom Ken, "Place-Based Urban Ecology: A Century of Park Planning in Seattle", op. cit.

29. Shapiro Sheryl, "Seattle Public Utilities", Personal communication, Longfellow Creek Watershed Project, 2 March 2006. 
infrastructure ${ }^{30}$. Among the two charette teams focused on the downtown core, homelessness was conceived of only in terms of threats to the safety of housed residents who entered public spaces. During early designs, participants inserted new green spaces onto the map, replacing spaces occupied by shelters and transitional housing which were removed in an effort to enhance the ecological functioning of the city while homogenizing the social diversity of downtown residents.

In the economics and planning literature, gentrification is typically conceptualized in terms of the transition of property rights ${ }^{31}$. As a process of economic development, gentrification involves the displacement of residents from low-rent, often-times formerly industrial neighborhoods by higher-end real estate developments with the concomitant influx of higher income residents into these increasingly attractive spaces ${ }^{32}$. Green spaces, including parks, are conceived of as tools of economic development ${ }^{33}$. Parks are framed as vehicles for social reform, beginning with the Olmstedian notion of parks as spaces of democratization and socialization ${ }^{34}$, and

30. The University of Washington, in collaboration with the Urban Land Institute, the City of Seattle, and local design firms, sponsored a public design charette to create a 100 year plan for Seattle's open spaces. The final report and green infrastructure maps are available at: http://www.open2100.org/. Envisioning Seattle's Green Future: Visions and Strategies from the Green Futures Charette, RоттLе Nancy, MARYMAN Brice (dir.), Open Space 2100 Project and the University of Washington, Department of Landscape Architecture, February 3-4 2006, available at http:// depts.washington.edu/open2100/book/book.complete.pdf.

31. Palen John, London Bruce, Gentrification, Displacement, and Neighborhood Revitalization, Albany (N), University of New York Press, 1984; Blomely Nicholas, Unsettling the City: Urban Land and the Politics of Property, New York (NY), Routledge, 2004.

32. Sмiтн Neil, The New Urban Frontier: Gentrification and the Revanchist City, London, Routledge, 1996.

33. Cranz Galen, The Politics of Park Design, Cambridge (Massachusetts), MIT Press, 1982; Crompton John, Parks and Economic Development, Chicago (Illinois), American Planning Association, 2001; Low Setha, Taplin Dana, Scheld Suzanne, Rethinking Urban Parks: Public Space \& Cultural Diversity, Austin (TX), University of Texas Press, 2005.

34. Sheridan Miriam, The Olmsteds in Seattle: a Continuing Legacy of Parks and Boulevards, draft, Sheridan Consulting Group with Artifacts, Inc., March 2004; Low Setha, Taplin Dana, Scheld Suzanne, Rethinking Urban Parks: Public Space \& Cultural Diversity, op. cit.; Dooling Sarah, Simon Gregory, Үосом Ken, "PlaceBased Urban Ecology: A Century of Park Planning in Seattle", op. cit. 
currently associated with public health issues, often framed in the language of new urbanism ${ }^{35}$.

The concept of ecological gentrification challenges many of the assumptions associated with the definitions, uses, and values of green spaces developed in planning literature and practice. Specifically, ecological gentrification problematizes conventional agency approaches to using green spaces as tools facilitating social reform and public health objectives, and as tools promoting economic development for the benefit of private property owners. The dialectical relationships between economic processes displacing economically marginalized residents coupled with the loss of affordable housing, and the implementation of an ecological agenda for urban green spaces has not been explicitly linked to homelessness. Recognizing the connectivity between urban green spaces and homelessness is a movement towards resisting the production of bare life for homeless individuals.

\section{Re-Negotiating Concepts of Justice in the City \& Strategies Resisting Bare Life}

Resisting bare life requires a politics of emancipation and the possibility of antagonistic social practices. In a recent critique, Ernesto Laclau asserts that Agamben's concept of sovereign power as a homogenous, pervasive, regulating entity called the State requires socially isolated individuals absent any sense of collective identity and agency ${ }^{36}$. He charges that instead of bare life being the outcome of conflict between lawlessness and a juridical system imposed by some sovereign power, the conflict is actually between two systems that fail to recognize each other. That is, bare life is the result of two incompatible systems of life - the life of the legitimate citizen, housed and economically productive, deserving of and afforded full legal protection; and the life of a person existing in a zone of indistinction, targeted and vulnerable to expulsion, exclusion and erasure in urban spaces while not considered deserving of legal protection. My research demonstrates homeless individuals do exercise agency in their decisions to live outside in order to maintain selected qualities of living - autonomy, dignity, sobriety for some, and connections to nature for others - while risking incarceration. Ecological gentrification attempts to conceptually integrate

35. Katz Peter, New Urbanism: Toward an Architecture of Community, New York (NY), McGraw Hill, 1994.

36. LaClau Ernesto, "Bare life or social indeterminacy?", op. cit. 
these two seemingly incompatible systems of urban living by motivating recognition among policy makers and planners that green spaces and environmental planning, in addition to housing, welfare, and employment, are involved in urban homelessness. Only with mutual recognition between social and environmental planning systems can effective strategies resisting the production of bare life be developed.

The concept of ecological gentrification provokes a re-negotiation of justice in relation to housing, planning, and the interrelatedness of social and ecological transformation of urban spaces. Within the planning and policy analysis literature, homelessness is conventionally analyzed as an economic justice issue related to affordable housing and employment. Yet, the decisions made by homeless people to sleep outside reveal the need for a concept of justice that recognizes the qualities and aspects of home these individuals seek and need, and a revision of housing and shelter that currently dominates the social service industry. Policy makers specific conceptions of housing and shelter resists the production of bare life and hinder the effectiveness of housing people by repressing those who decide to sleep in urban green spaces. This revised vision of social justice embraces a robust pluralism of home, and challenges policy makers to ask: How might policies, plans, and programs look different if, instead of focusing on shelter and housing, we focused on social networks, senses of belonging, processes of recovering from trauma, connecting to nature, dwelling without walls, and multiple cosmologies?

One strategy that initiates resistance to bare life for homeless individuals is the creation of an outreach program where outreach workers enter green spaces with the goal of listening in order to understand more clearly the reasons individuals have for camping in green spaces. This outreach strategy is very different from conventional outreach efforts whose goal is to provide information about housing and services, enforce civility ordinances, and convince homeless individuals to use shelters during extremely cold weather. Outreach strategies grounded in an appreciation of a pluralistic notion of home requires workers to interact with homeless individuals in less controlled environments, and needs to incorporate what is shared into the production of diverse housing options and strategies.

Ecological gentrification also re-negotiates concepts of nature through the recognition that green spaces, in addition to being valued for wildlife habitat and ecosystem functioning, are also places of human habitation. In providing relief and refuge from and residence within heavily urbanized environments for human and non-human urban inhabitants, green spaces are also habitations of last resort for those people unable to gain access to 
the formal housing market and unwilling to suffer violence and humiliations in the shelter and housing systems. The integration of social and environmental planning systems points to a practice of spatial justice. For planning, spatial justice can be thought of as an approach to urban phenomena that acknowledges the totality of spatial locations and practices which supports diversity - for example, a diversity of home and housing options, and a diversity of values and uses of green spaces. In relation to homelessness, spatial justice integrates social and environmental systems and efforts, and begins with the recognition that homeless individuals are managed in all urban spaces - sidewalks, alleys, parking lots, parks and green spaces, shelters, and even single-room occupancy. Even future designs of green infrastructure developed by local residents produce markers of bare life for homeless individuals. A spatially just planning approach recognizes the moral calculus operating within and motivating current social policy developments and recognizes the totalizing aspects of an environmental agenda that ignores consequences of ecological transformation on vulnerable human populations. A spatially just approach might motivate policy makers and planners to ask:

- How might embracing expanded notions of home motivate re-imagined notions of green spaces?

- How might re-imagined notions of green spaces expand notions of home and homelessness?

- How might transformed notions of green spaces motivate dialectical approaches to other urban planning efforts, by recognizing the interconnections and complex relationships among inhabitants of urban spaces (human and non-human) and (social and natural) processes?

A strategy that promotes connections between social and environmental planning efforts proposed by homeless individuals is the creation of a Green Stewardship Program within the parks department. The program would allow homeless campers in green spaces to remain there, harassment-free, while working for the parks department to remove non-native vegetation. Workers would receive a living wage as employees of the parks department while implementing one of the park department's major ecological agenda items in urban green spaces. Creating opportunities for participation in the formal economy through this proposed program could potentially cultivate perceptions of homeless people as productive inhabitants of urban green spaces, while the policies addressing the production of housing continue. 


\section{ConcLusion}

Both of these strategies emerge from re-negotiated concepts of justice, home, and nature, where interactions and interdependencies between multiple human and natural systems are recognized - that housing is related to homelessness, and that homelessness is related to green spaces, and that complex green spaces are produced by social and ecological transformations informing each another. A spatially just approach to planning recognizes the totality of urban inhabitants - housed, non-traditionally housed, homeless, and non-human - and in doing so, challenges the ideological constructions of home, homeless, and green space. As long as people sleep outside as a decision of last resort; as long as conceptions of housing and shelter blind policy makers to the diverse needs for social, cosmological, and psychological aspects of having a home; and as long as the inter-relatedness of ecological and social processes involved in the transformation of urban spaces is denied, bare life will continue to unfold.

Sarah Dooling

School of Architecture and the Environmental Science Institute, University of Texas, Austin 



\section{"Bad Spaces?": Interrogating Suburbs, Myth and Spatial Justice}

$\mathrm{T}$ HE RIOTS THAT HAVE repeatedly encircled Paris and ignited other suburban communities around France in the $21^{\text {st }}$ century provide iconic visions of the banlieue as social problem. Powerful images of burning cars, angry youths and social injustice resonate with cinema ${ }^{1}$ and social studies that analyze "ces banlieues qui nous font peur". For many global spectators, the vivid demands of these youths in bleak places far from the promises of Paris, have epitomized issues of space and social justice through the stark polarity of city and suburb. Yet, as Alain Touraine noted decades ago, "Ce qu'on appelle d'un terme symbolique la banlieue, c'est justement cette zone de grande incertitude et de tensions où les gens ne savent pas s'ils vont tomber du côté des in ou du côté des out ${ }^{3}$ ".

Rap artists, journalists and social analysts have drawn parallels between these banlieues and American inner cities ${ }^{4}$. By contrast, these iconic Parisian suburbs seem far from the middle class homes, lawns and private lives associated with American suburbia, which have spatialized the American dream for many. Both developments embody terrains of difference vis-àvis the city, but the content of the difference appears irreconcilable. Commentators, nonetheless, have attacked American suburbs for social segregation, cultural complacency, ecological depredation and even issues of physical and mental health. In fall 2008, with the U.S. facing a national mortgage crisis, high gas prices and crises of confidence, an observer even

1. Mathieu Kassovitz, La Haine, 1995.

2. Lançon Georges and Bouchoud Nicolas, Ces banlieues qui nous font peur, Paris, L'Harmattan, “Questions Contemporaines”, 2000.

3. Touraine Alain, "Face à l'exclusion", in Citoyenneté et Urbanité, Paris, Esprit, 1991, p. 165-173 et 167.

4. WaCQuant Loïc, "Urban Outcastes", in International Journal of Urban And Regional Research, n 17/3, 1993, p. 366-383; Boyer Jean-Claude, Les Banlieues en France, Paris, Armand Colin, "Collection U” 2000; etc. 
spatialized regional problems in once-glorious suburbia: "the story of vacant suburban homes and declining suburban neighborhoods did not begin with the crisis, and will not end with it. A structural change is under way in the housing market - a major shift in the way many Americans want to live and work. It has shaped the current downturn, steering some of the worst problems away from the cities and toward the suburban fringes ${ }^{5 "}$. As historian Becky Nicolaides observed, images of Hell have been transposed onto Arcadia ${ }^{6}$.

In this essay, I reread American suburbs (and other global suburbs) to highlight a complex underlying theme: the transformation of varied suburban peoples and places into myths of the anti-city and the implications of the designation of suburbs as "bad places" for inclusive metropolitan spatial justice. From France and the U.S. to Latin America, Asia, and Africa, gated communities, habitat pavillonaire, shantytowns, grands ensembles and sprawling subdivisions of uniform houses have formed elements in discussions of the good city. Yet, in many cases, this use of suburbs in metropolitan arguments involves a reduction that conceals the complex historical, social and economic processes that constitute such areas, the agents who work to better them and the shared forces creating or constraining cities and suburbs. Suburbs as "bad places" have an intimate relation to urban social justice in so far as they are read as projections and opposites rather than places of growth that share problems of race, class, gender and civic rights. Whether suburbs are heavens or hells, mythologization undercuts voices who should be part of local and regional discussions and solutions of spatial justice.

In defining myth, I draw primarily on its use in anthropology (while recognizing important convergences with Lefebvre's conception). In anthropological terms, a myth is a narrative-like cluster, often set in past or distant (disembodied) times, that charters values, institutions, dialogue and conflict in the present. In contemporary multi-mediated societies, these narratives echo and transform across multiple media - journalism, mass media, academic studies and personal narratives. This diffusion introduces indeterminacies in story and interpretations and also conceals underlying elements. In no case, though, should myths be taken as mere falsehoods,

5. Leinberger Christopher, “The Next Slum?”, in The Atlantic, mars 2008, http:// www.theatlantic.com/doc/200803/subprime.

6. Nicolaides Becky, "How Hell Moved from the City to the Suburbs", in The New Suburban History, Kevin Kruse and T.J. Sugrue (eds.), Chicago, University of Chicago Press, 2006, p. 80-99. 
even if they are false (as Orfield notes in his seminal American Metropo$\left.\operatorname{lics}^{7}\right)$. Myths are framing rather than falsifiable; hence, their invisible power in policy and other issues.

For anthropological work in contemporary settings, literary critic Roland Barthes remains a key figure because of his recognition of the politics of myth in everyday life, crystallized in concrete places, objects and scenarios of modern France and his attention to functions through which myth reinforces power". Barthes saw myths as the "Signes Zodiacaux de l'univers bourgeois : les Essences et les Balances"'. His readings of modern French space and society, in fact, guide us in a skeptical analysis of dichotomies of suburb and city that have framed spatial questions, excluded voices and thwarted meaningful responses. Such dichotomies invoke recurrent processes of myth, including the concealment of history, arguments through false alternatives, and reduction of data. Barthes' insights also inform a dialogue with recent scholars in media, urban/suburban history and related fields ${ }^{10}$.

To link myth and demythologization to spatial justice, we also must remember Barthes' observation that "statistiquement, le mythe est à droite. Là, il est essentiel, bien nourri, puissant, expansif, bavard ${ }^{11} . .$. ." This recognition, fundamental to imbalances of power and voice between cities and French banlieues or Latin American villas miserias, proves equally compelling in settings where suburbs are identified with power, as in the U.S. Demythologization, in turn, moves toward inclusive spatial and social justice: to challenge myths, we must explain how constructed differences have divided society and restricted inclusive dialogue and change. At the same time, we must grapple with the lived experiences that myths ignore. Only

7. Orfield Myron, American Metropolitics, Washington, Brookings Institute, 2002.

8. Barthes Roland, Mythologies, Paris, Éditions du Seuil, 1957.

9. Ibid., p. 259-264.

10. Spigel Lynn, Welcome to the Dreamhouse, Durham, NC, Duke, 2001; AmoRIN Marilia, Images et discours sur la banlieue, Paris, Érès, 2002; Orfield Myron, American Metropolitics, op. cit.; Katz Jack, "Metropolitan Crime Myths", in New York \& Los Angeles, Halle David (ed.), Chicago, University of Chicago Press, 2003, p. 195-224; Dikeç Mustafa, Badlands of the Republic, Oxford, Blackwell Publishing, 2007; Kevin Kruse and T.J. Sugrue, The New Suburban History, Chicago, University of Chicago Press, 2006; esp. Nicolaides Becky, "How Hell Moved from the City to the Suburbs", op. cit.

11. Barthes Roland, Mythologies, op. cit., p. 257. 
with critical reading and experiential investigation can we reimagine suburbs within a different paradigm, in which:

The scope of the polity... ought to coincide with the scope of the obligations of justice which people have in relation to one another because their lives are intertwined in social, economic, and communicative relations that tie their fate ${ }^{12}$.

My examination of suburban myth is grounded in historical, ethnographic and cultural studies, everyday life in American metropoles, and comparative fieldwork in suburban Paris, Hong Kong, and Latin America. In this global project, I have examined structural and visual forms, processes of political economic development and the social, cultural and texts about places outside the city while raising children, shopping, eating out, being a neighbor and commuting. The quotidian cannot refute myth but often challenges it. Comparison, similarly, underscores how myths shape spatial justice in general and homogenize, silence and divide spaces and people. To illustrate problems in this essentialist separation in this essay, I focus on two key themes in U.S. materials: the racialization of space and justice and the (mis)reading of public spheres and alternative sites of metropolitan dialogue.

\section{Divided Metropoles: \\ Race, Place and Suburbs}

In the United States, postwar suburban development often has been explained by stark geographies of the "Other", delineated via race and class. "White flight", for example, identifies suburbs with racialized escape of the white middle class from the city. Many suburban stories emphasize such exclusiveness: Herbert Gans, for example, in his classic Levittowners chronicles how African-American families were excluded in this new development outside Philadelphia ${ }^{13}$. Gans, however, carefully showed how new suburbanites continued attitudes formed in the city rather than simply inventing or expressing new forms. And, over decades, Levittowns have become integrated in multiple dimensions as they have evolved in physical form and social meaning.

Racialization, for many liberal urban observers, nonetheless transformed the utopian imagery of earlier elite suburban development, adding dark

12. Young Iris Marion, Democracy and Inclusion, Oxford, Oxford University Press, 2000, p. 229.

13. Gans Herbert, The Levittowners, London, Penguin, 1967. 
moral dimensions. Images of suburbanite's abandonment of the impoverished racialized inner city, for example, spatialized fundamental questions about inclusive versus exclusive social visions and shared responsibilities versus private gains. Yet, this fundamental creation myth of suburbs, which journalists and even academics invoke today, overlooks historical processes, local complexities and cross-cutting metropolitan processes.

Pennsylvania's Main Line, for example, where I live and teach, is an elite railroad suburb that formed around great homes in the late $19^{\text {th }}$ century ${ }^{14}$. Myths of race, class and space have been reinforced by the built fabric of great estates, journalists and social commentators and Hollywood films like George Cukor's Philadelphia Story (1940). In the early $20^{\text {th }}$ century, essayist Christopher Morley, scion of local suburban university professors, used the commuter rail journey from the city to these suburbs to crystallize his vision of Arcadia:

At Overbrook one gets one's first glimpse of those highly civilized suburbs. It is a gloriously sunny May afternoon. Three girls are sitting under a hedge at the top of the embankment reading a magazine... Toward Merion we skirt a brightly sliding little brook under willow trees, with glimpses of daintily supervised wilderness. It is all so trimly artificial that one is surprised to see that the rubbery stalks of the dandelion have evaded the lawn-mowers just as they do in less carefully razored suburbs ${ }^{15}$.

Vivid, personal images here create a transcendant space of controlled nature, gendered leisure, and "civilization." Unspoken rights of race and that bind these images into "the loveliest spot on earth, now and forever ${ }^{16 !}$ ".

Even as Morley wrote, however, African-American, Irish, Italians and other working class Americans had joined wealthy homeowners on the Main Line. They found stable employment in great homes, on the railroad, or in institutions such as colleges, hospitals, hotels and government. While Morley opposed the sylvan idyll of the Main Line to the smoke, vacant ground and rowdy children of the city, social researcher Marion Bosworth noted a spatial symbiosis across classes in a report on housing that claimed spatial justice for those confined in the slums of the Main Line: "if the

14. Lower Merion Historical Society, The First 300: The Amazing and Rich History of Lower Merion, LMHS, 2000.

15. Morley Christopher, “The Paoli Local”, in Christopher Morley's Philadelphia, Ken Kalfus (ed.), New York, Fordham University, 1990, p. 12-14, p. 229-30.

16. Ibid., p. 231. 
country is good for the rich it is also good for the poor, and if the country is desired by the rich it may likewise be desired by the poor ${ }^{17} . .$. . Here, spaces of the Main Line become dystopic:

Workers living in places where filth and squalor and disease are more prominent even than country air and sunshine, and laboring in the country by day where the very words filth and squalor seem anomalies, are another means of contact between the poorly housed and the well-to-do ${ }^{18}$.

Race and class converged as element and challenges for Main Line rather than issues "outside" the suburbs. Indeed, Bosworth read housing problems in the wider context of metropolitan social justice:

In the country the interrelation of rich and poor and their reciprocal effect upon each other is no less strong because it is not seen, as it were, through a magnifying glass, and is prone to be overlooked. The very thing which makes it possible for slums to exist in the country, the demand for workers, brings the connection between the two extremes of society very close ${ }^{19}$.

The Main Line, in fact, participated in wider national movements of race, class and space often invisible in later suburban myth. Andrew Wiese' work on African-American suburbia shows that working-class Blacks created their suburban spaces by moving towards the city (from rural and urban settings) as much as escaping from it. During the American Great Migration (1910-20), 15\% of all Black migrants moved to suburbs rather than cities in the North. They built homes that incorporated work places, productive gardens and rental sites for kin and others. After World War II, suburban development took more upper class residential retreats from the city as their "model" in both sales and "white" self-identity: an iconography of homogeneity that in turn would become an ahistorical paradigm for both supporters and critics. But as Wiese insists, the disappearance of African-American voice and examples from narratives of suburbia never meant displacement of African-American communities. Today, twelve million African-Americans live in suburbs ranging from old working class cores to

17. Bosworth Marion, Housing Conditions in Main Line Towns, Committee on Investigation of Main Line Housing Association, 1919, p. 4.

18. Ibid., p. 5.

19. Ibid. 
new elite subdivisions. Yet, even scholars of suburbia who have fought to integrate suburbs often accepted suburbia's intrinsic whiteness ${ }^{20}$.

As I have found in my own work, presence, historical and enduring, does not disprove myths of space or rights. In Savannah, Georgia, for example, in the early 1900s, Alsatian Catholic missionaries developed a near-suburban space on industrial lowlands west of the city for an African-American school and congregation. The Savannah Tribune of August 17, 1909 noted:

Lots are being sold there everyday. A few beautiful homes have already been erected by colored men, who are being moved by the praiseworthy ambition of having their own sweet home. Soon a nice colony of colored citizens will be established on that beautiful healthy spot where peace and happiness will reign supreme ${ }^{21}$.

Black suburbanization was part of preaching conversion and a religious commitment to racial justice, offering security, health and opportunity against the divisions of a segregated Southern city.

Despite decades of development, African-Americans complained decades later that the Catholic hierarchy did not recognize the spatial implications of their history. Closure of the black parish schools to produce integrated (previously white) units embittered many. Others argued that the diocese would not let them transfer an inner city, traditionally black parish to a new suburban lot they had acquired. Identified with urban missionary efforts to the poor, these parishioners felt they were denied the mobility through which white parishioners created new suburban churches. Ironically, some of these newer suburban parishes, in territories less imbued with urban racial categories, have experienced racial integration and incorporated new global migrants far better than fading white center city parishes. Still, myths of place and justice denied suburban movement as an option, much less a solution, for black questions about place and rights ${ }^{22}$.

This power of myth resonates among African-American, Irish, Italian, Jews and others in marked categories in Main Line settings today. In so far as "white" became an unmarked feature of suburban place, even anomalies came to reaffirm myth. By the 1950s, for example, the Woodman mansion, built by a $19^{\text {th }}$ century Euro-American industrialist, became the center for a worldwide Afrocentric religious movement and the charismatic Father

20. Wiese Andrew, Places Of Their Own, Chicago, University Of Chicago Press, 2004, p. 4.

21. McDonogh Gary, Black and Catholic in Savannah, Georgia, Knoxville, University Of Tennessee, 1993, p. 156.

22. Ibid. 
Divine, who showed his unique power by his place in of this white domain. A commentator in the 1980s added that "as one Main Line lady put it, One really ceases to be black or Jewish as soon as one is worth $\$ 10$ million $^{23}$ ". Differences of race fade along tree-lined streets of privilege.

Nonetheless, Black communities survive; churches, funeral homes, recreational and service associations and commercial institutions still are centers for specific ethnic and racial publics, sustained by generations of praxis rather than laws. Middle-class black families with long-rooted social ties and multiple local/national institutions form part of the variegated Main Line amidst new middle-class housing and a few remaining mansions. Yet, new people have moved into new developments and older housing, remapping spaces. On the one hand, multicultural professionals associated with local colleges and hospitals or metropolitan wealth have claimed places that affirm class while not challenging older images of oncewhite suburbia. On the other, neither the architectural fabric of older Black and working class areas nor neighbors themselves constitute fixed spaces. Outsiders identify these areas as affordable housing within an expensive suburban region of strong schools, low taxes and extensive services. Older Main Line African-Americans may resist gentrification of traditionally African-American (and working class ethnic) neighborhoods, but because of a widespread reading of suburbs as "White", they often lose their place and participation within this local space.

Meanwhile, other changes in race and place continue in the Main Line, as in other American suburbs, but may also be eclipsed by mythic racialization of suburbs. Chinese, Japanese and Korean families have formed Saturday schools that use Main Line facilities for cultural training and social gatherings that reflect their growing suburban presence. Koreans rent worship space from one of the oldest congregations in the area, whose traditional Euro-American membership has dwindled. A new Latino population has emerged in both work and housing around Philadelphia, raising new questions of social justice with regard to new laborers in the community - echoing Bosworth's 1919 comments. All these groups have become important in the transformations of other American suburban areas - yet mythic contrasts of homogeneous white suburbs and diverse cities conceal ongoing transnational transformations.

23. Mallowe, 1983, in Pottinger Trecia, Rethinking Race, Class and Space on Philadelphia's Main Line" Black Suburbanites in Ardmore Pennsylvania, Unpublished Dissertation, American Studies, University of Minnesota, 2008, p. 31. 
Moreover, the powerfully discrete myth of the Main Line is not bounded by opposition to the city alone. Recognition of suburban diversity and its implications for inclusive justice must take into account the evolving regional physical, social and cultural context as well. Norristown, for example, the capital of Montgomery County, is a small suburban post-industrial city facing issues of economic restructuring among many poor and minority residents. One Levittown development in the area has celebrated its fiftieth anniversary of change and diversification, inviting Gans himself as a keynote speaker. Nearby Upper Darby has accommodated multiple migrations yet has become a center for Korean investment and commerce. Meanwhile, outlying suburbs have been sites of rapid greenfield development that outstrip planning and services despite strategies to conserve land and privilege through conservancies and other strategies of zoning and reproduction $^{24}$. These suburbs and their residents have strong feelings of difference and distinctiveness vis-a-vis their "neighbors." Reducing them to a simple geography of white middle class communities obscures historical processed and complex motivations that have created metropolitan black, white and hybrid suburbanization.

Such mythological divisions increase the difficulty of seeking metropolitan social justice across culturally-accepted divides. A review of changing issues of poverty in the U.S., for example, notes that:

Shifts caused the city-suburb poverty gap to narrow overall, but the rift remains wide, to the point that city residents remain more than twice as likely to be poor as their suburban counterparts. Likewise the share of the poor population residing in suburbs increased during the 1990s, though even so, half of all poor people in the United State's largest metropolitan areas still live in central cities ${ }^{25}$.

Older suburbs in the U.S. have become centers for immigration, racial mixture and concomitant "urban" questions of poverty or educational demands which vary, as noted, among the Main Line and other contiguous places but ultimately influence all of them as well as the cities they surround. While suburbs and cities differ, they do so within shared trajectories that suggest the need for shared solutions. In the past few years, in fact, grassroots demands have challenged mythic barriers as Greater Philadel-

24. Rybczynski Witold, Last Harvest: From Cornfield to New Town, New York, Scribner's, 2008.

25. Frey William H, "Melting Pot Suburbs: A Study of Suburban Diversity", in Redefining Urban and Suburban America: Evidence from Census 2000, Katz Bruce J. and LANG Robert E. (eds.) vol. 1, Washington, DC, Brookings Institute, 2003, p. 17-136, p. 131; see Orfield Myron, American Metropolitics, op. cit. 
phians have met and discussed common issues, creating a new space for "First Suburbs" cutting across jurisdictions of city and county, following people and issues instead of boundaries.

The diffuse distribution of social issues and social solutions in these U.S. cases has global implications. Squatters and poverty taken as emblematic of the periphery of many Latin America cities constitute powerful symbols of fear and division within the metropolis. Yet, residents from these areas work across the city and its spaces even if they cannot find homes there. At the same time, we should also pay attention to the multiple meaning of "walls" in Latin American suburbs, where elite gated communities have now laid spatial claims to many shanty areas. Here, scholars have suggested that these areas may be symbiotic as well as antagonistic, as elites rely on a local labor pool and squatters experience improved local facilities and voice $^{26}$. Resolving these issues demands Young's wider dialogue rather than walls of exclusion and hostility that preclude spatial justice for cities and squatters peripheries.

All these examples challenge simple, absolute division of bad suburbs and good cities through essentialization, contrast and alienation of history in Barthian terms. Constructed polarities divide publics and issues through false absolutes; thus, these processes shape how space and justice are conceived, much less achieved. They also may silence or conceal sites of dialogue and new visions themselves within this mythic landscape, as we may see in an examination of suburban public spheres and spaces.

\section{Public, Private and Non-Spaces: Crucibles of Social Justice}

Reduction of suburbs to monolithic images raises issues of spatial justice within suburbs and within larger connected regions. Another set of images of American suburbs as "bad spaces" identifies them as inarticulate place markers in such debates as well. Mythic U.S. suburbs are distilled into mute mass media icons such as a single-family home, the car (station wagon, van, SUV), lawns and malls; all these images evoke pervasive themes of privacy, exclusion and alienation in opposition to the vital public spaces and public spheres of the city championed by Jorgen Habermas, Jane Jacobs or Lewis Mumford. Hence, in mass media, planning models and

26. Salcedo Rodrigo and Torres Alvaro, "Gated Communities in Santiago: Wall or Frontier?", in International Journal of Urban and Regional Research, $\mathrm{n}^{\circ}$ 28/1, March 2004, p. 27-44. 
academic texts, the home and car become insular domains; the mall, a corporate pseudo-public space; and television, an insidious villain. Suburbs are places without dialogue or ideas.

Metropolitan commentators and planners often have cited these features of suburbia as harbingers of spreading alienation, opposing a mythic city of public contact, exciting encounters and rich discussions to seemingly empty, alienated spaces where passive suburbanite live within cocoons of spatial exclusivity. Such images pervade plans for reform of soulless suburbs, from New Towns to New Urbanism. One might object that such visions idealized the city as well: not all cities are New York, Berlin or Paris. Nor are elite cafés and other fora prized by flaneurs and commentators equally accessible to all citizens. Small cities, working class neighborhoods and suburbs may lack canonically intense public spaces, but they also incorporate interesting alternatives. Through recognition of mythic reductions and suburban experiences, in fact, we can learn about wider forms of public space, public spheres and spatial justice in cities as well.

Often, the issue seems to be how we read spaces of planned or new development as well as people who use, connect and complicate even anodyne places ${ }^{27}$. As a suburban resident and scholar, I know banality and places of emptiness. I also experience multiple public and semi-public spaces where my neighbors interact as parts of everyday life. Defining suburbs as lands without expected urban public spaces in opposition to "cities", though, denies the very possibility of agency in social action, of voices of dissent and change. Instead, I argue that these interactions are intrinsic to suburban life and underscore connections to urban fora as well as possibilities for local and metropolitan social change. Examples are surprisingly easy to find in life, if not in the literature on these suburbs, as I suggest through my own rhythms of schools, associations, libraries and churches as well as research in the U.S. and abroad.

Many American critics of suburbs, for example, have signaled public schools as critical sites of investment, population and privilege dividing cities and suburbs (despite the wide variation among suburbs in many regions $\left.{ }^{28}\right)$. Schools, however, also articulate multiple "communities" around activities, responsibilities and social networks. Networks grow through children and class activity: ongoing reproduction as a goal of suburban homes. Schools also evoke counterpublics epitomized by images of youth gathering in marginal space in American suburbs - parking lots, cemete-

27. Kolв David, Sprawling Places, Athens, University of Georgia Press, 2008.

28. Orfield Myron, American Metropolitics, op. cit. 
ries, wild parties, and unpoliced school functions - that locate intergenerational debate in suburbs as well (and resonate with images of banlieues and shantytowns as well).

Associations transcend schools through parents as well. The morning bus stop, for example, becomes a site for conversation, gossip and politics. This intensification of neighborly contacts across generations creates functional political and social networks in home and school associations. School issues motivate political forums as well: local elections have turned on school funding and taxation issues, while redistricting brings parents and students into public meetings.

Yet public spheres originating in suburban public schools do not embrace the entire territory of even the Main Line, where elite private schools that screen candidates according to various criteria while charging for their selective educational services. Catholic and Jewish schools also reconstitute suburban ethnic identity and community. Together, these account for nearly one-third of all students, creating a complex tapestry of institutions and meanings. All these facilities, as monumental semi-public places, can foment other networks around Saturday immigrant schools, sporting events, and public performances. And all connected with other urban and suburban schools through partnerships, rivalries and circulation of teachers and students over time.

Despite American sociological concerns with declining social capital in suburbia, a vast range of associations also unites and divides this suburban space, organized around places, ethnic groups, interests, social categories or gendered roles (women's clubs). Some also bridge social divides to create social capital and address the inequalities intrinsic to local space. The century-old YMCA (Young Men's Christian Association), combines religious and civic mission on the Main Line. It moved five decades ago from a commercial location near to traditionally black and working class men to a site ensconced in more upscale, predominantly white residential zone one kilometer away. Nonetheless, it promotes diverse participation in camps, after school programs and athletics and shares programs with YMCAs across the metropolitan region.

Other suburban institutions go beyond formal roles implicit in architectural monumentality to foster multiple publics. Main Line libraries, for example, are among the most monumental of public institutions near my home. They provide books, films and other material to any resident of the township. As social and intellectual centers, they participate in campaigns of shared reading that echo the "One Book, One City" campaign of Phila- 
delphia. In addition, libraries offer meeting spaces, drop off points and after school activities, and host myriad activities for citizens of all ages, ranging from story readings to tutoring to temporary shelter for the homeless. In fact, the very complexity of these centers underscore how multilayered communities are as branches encased in sober Quaker buildings combine special African-American collections with large print books, children's rooms and heavily used computers. Library environs provide important open spaces as well. Their lawns have hosted summer concerts, art exhibits and political actions; I have met neighbors in candlelight vigils against the war and random encounters on the steps of branches. Here, it is not their difference from urban public spaces but the roles these spaces share with similar urban institutions of conversation and protest that demand demythologization. And suggest that we also pay attention to the intersection of other open spaces - parks, playgrounds and even semiprivate swaths of lawns - as places of social interaction as well as boundaries.

As I have noted in other work ${ }^{29}$, the problems in essentialist oppositions of public cities and private suburbs seem especially acute with regard to churches, synagogues and other religious spaces. Despite religious institutions' recognized roles as platforms for ethnic integration and urban protest in American history, suburban churches have been met with skepticism or glossed over in suburban studies. Even reports that highlight the centrality of churches in far-flung new exurban growth - providing social centers, daycare and schools and support in areas not served by the social contract of public governance - often use these examples to lament the absence of "real" public spaces and spheres. This resonates with an antagonism to churches as public spaces among postwar suburban planners and reformers in the United States - a theme that deserves comparative considerations in other exurban settings. Such new models and analyses, however, pay scant attention to processes that have created urban and suburban spaces.

Across the U.S., religious meetings in homes were often the first sites of local and community life in nascent suburbs and points of identity in places swallowed by exurban growth. Congregations, buildings and cemeteries became nuclei for those who have created community life outside settled urban centers, as in the early spread of Philadelphia Quakerism that still anchors historic Main Line settlements. Over succeeding centuries, people, institutions and meanings of religion have moved from city to suburb, where citizens have actively recreated have added history and memory to

29. McDonogh Gary, "Suburban Place, Mythic Thinking and the Transformation of Global Cities", in Urban Anthropology, vol. 35 (4), 2006, p. 471-501. 
the raw new landscapes of suburbs. In some cases, the existence of a fledgling religious nucleus has been a promise of continuity; in others, it has been one of the first spatial commitments or the first marker of difference.

Suburban history and diversity are intertwined with the religious landscape and its social meanings and the Main Line township of Lower Merion has more than sixty religious institutions for its 58,000 residents. Even in the material presence of their sanctuaries, religious spaces, with their opportunities for teaching, preaching, discussion and identity constitute a network of styles, populations and issues rather than suburban homogeneity. Landmark Episcopalian churches claim landscaped places of privilege, while other denominations have adopted colonial or Gothic designs as statements of history, while several synagogues and churches boast intensely modern style. Still others have converted Main Line mansions into sanctuaries for Armenians, Catholic Colleges and the home of the Foundation for Islamic Education.

Churches anchor time and power in suburban space. Although some approach mega-church status with more than 3,000 members, or dominate neighborhoods with their spires and chimes, others hang on with only a handful of loyal supporters. While many of these institutions occupy visible places along major suburban arteries, African-American churches, anchors of their communities, tend to be tucked away in side streets. Their congregations, nonetheless have been vocal and visible in many questions of race and social justice while other citizens have crossed color lines to create religious and social places of integration.

Beyond sanctuaries and cemeteries, Main Line religious institutions also recreate faith communities through schools, including multiple regional seminaries, Catholic and Quaker colleges, and Catholic, Jewish, Episcopalian and Islamic day schools. These complement the daycare, youth training and adult activities that affirm generations and life courses within individual congregations.

Religions sites are, of course, "private" spaces. In practice, however, they often act as semi-public spaces, hosting concerts and town planning meetings, day care, Alcoholics Anonymous, educational projects and diverse social groups. On election days, canvassers and voting machines bustle in and around church basements. Certainly such places may become nodes of exclusivity, discrimination, injustice and even hatred. Still, their partial permeability forces us to rethink the concepts of public space used in urban discourse, where religious and private origins of public spaces have been concealed under centuries of evolving use. 
Finally, the religious public sphere, like other associations, crosses urbansuburban divides. Catholic and Jewish social justice missions act on a metropolitan level. Partnered denominational institutions create social ties across jurisdictional lines. Religious affiliates have been active in First Suburbs meetings I have attended at a college in the Quaker tradition (Bryn Mawr), a suburban Catholic high school and a Catholic parish in Norristown. Moreover, people from suburbs may drive hours to participate in an inherited urban community, while others may change congregations in search of leadership, ambience and issues.

These spaces may not resemble the great public squares or idealized cafés that has dominated discussion of the public sphere. Yet, we must not equate form with function - whether demanding grand plazas in suburbs or assuming that all such inherited spaces fulfill these idealized social roles in contemporary cities. Suburbs, reflecting their origins in expansion beyond cities, are about creating space, physically and socially, rather than the manifest hierarchies that often have characterized urbane constructed public spaces. Within this ongoing evolution of new places, the sheer ordinariness of suburban public spaces and public spheres renders them less visible but all the more important to identify as crucibles for discussion of spatial justice. Exclusions or undervaluation of churches, schools, libraries (and markets, streets, post offices and stores) by planners and academics obscures the variety and evolution of suburban space, society and culture and fundamental quests for meaning and justice that suburbanites share as global citizens.

In global suburban settings, many depictions of the poverty of public space echo the bland landscape imputed to American suburbia. Public and semi-public social spaces - schools, bars and restaurants, streets, markets, churches and other sites - nonetheless articulate these landscapes worldwide. In France, for example, religious institutions seem to have claimed problematic places in working class suburbs, whether in the rise and fall of worker-priests in older suburban factories or the religious institutions of new suburban Islam - and the lives of suburban synagogues - that have surfaced in discussion of social unrest. Indeed, a 2008 New York Times piece underscores the creative connection of religious spaces as Muslim students find spiritual sanctuary and dialogic homes within Catholic schools, constituting perhaps $10 \%$ of all Catholic school students ${ }^{30}$. Other portraits of contemporary banlieue life emphasize the intense creation of spaces of

30. Bennhold Katrin, "French Muslims Find Haven in Catholic Schools", in New York Times, September 29, 2008. 
interaction around bars, markets and schools, or, in the case of alienated youth, around almost any abandoned space within their environment ${ }^{31}$. These texts and studies underscore connections of urban and suburban lives and the significance of suburban counter-publics for lived geographies that disrupt mythic spaces and reframe spatial justice. Analysts have even underscored how creative use of "bad spaces" can foster community through shared experience in zones like Sarcelles and La Courneuve, identified with the bleakest alienation of French high-rise public housing ${ }^{32}$. Perhaps the messages of rap, novels and conversations in Petit Casinos, garages and market stalls can teach us about agents and actions who define spaces of potential justice even within bleak suburbscapes.

In denying the public sphere of suburbia, planners and analysts shaped by urban myths and belief in difference overlook the malleability of space and the creativity of human populations. Not recognizing that many places can serve as points for the creation of diverse publics within a metropolitan region, they reaffirm visions of inevitable separation. In denigrating or disallowing these possibilities, they also delimit voices and concerns of the public space/public sphere that might allow agents to respond and go beyond their complaints.

Instead, I argue that interrogations of suburban public space and public spheres help us reinterpret public spaces and spatial justice in cities as well. When police patrol urban parks worldwide to exclude skateboarders or protestors, libraries close on weekends due to shortage of funds and gentrification challenges the boundaries of behavior in parks and streetscapes, are malls, churches and other "suburban spaces" qualitatively different or points on a spectrum of creative and hybrid spaces with a range of present and potential meanings? Suburban issues offer challenges within wider metropolitan and national frames that balance institution and process, social justice and ideologies of space and place.

\section{Conclusions: Spaces, Voices and Justice}

Suburban myths, in the U.S. and many other places, have become "second nature", fodder for situation comedies and journalistic commentary. Visualizations of American suburbia replete with white middle-class single-

31. Charef Mehdi, Le Thé au harem d'Archi Ahmed, Paris, Mercure de France, 1985; Lepoutre David, Cour de banlieue, Paris, Odile Jacob, "Document", 1997.

32. See the local socialist housing blog on this point at hto://ps-sarcelles.hautetfort.com/archive/2006/04/21/note-ed-lecture-sarcelles-une-utopie-reussie.html. 
family homes with stereotyped gender roles, spaces and characters facing offstage work or danger reproduce myths across media and society, as noted in a review of the American cable series Weeds:

When all else fails, when American life gets too complicated and wacky to get a good satirical hold on, writers repair to the suburbs. The unlovely secrets harbored by the ranch houses, and bi-levels, by the lawns and empty sidewalks of the towns lying just beyond the fervid cities have been to American novelists, screenwriters, and television writers what plutocrats were to Daumier. Behind every traveling sprinkler there is a penis longing to wander.

Artists and intellectuals have always hated the suburbs, probably because it's the cities that produce works of art and intellect ${ }^{33}$.

Guided by historical, ethnographic and political economic data, we can reread these images to understand more complex relations of myth, power, voice and spatial justice. Such an approach resonates with Myrto Konstakorakos' reading of French banlieue films as oppositional voices that challenge reductionist polarizations of space:

despite their label, they are not strictly about banlieues, but about the distance between the centre and the margin and the stark division between two worlds that cannot understand each other, nor communicate to reduce their tensions. The banlieue films challenge the official representation of space by rethinking the relationship between centre and peripher $y^{34} \ldots$

These readings take us back to central questions of space, dialogue and justice that have been argued here through the fundamental claim that both suburbs and cities, as spaces of myth, demand nuanced analysis. Shared myths of suburbia, generalized within both metropolitan and national cultures, heighten contrasts and normalize symbolic spaces within a tense, changing and vitally interconnected metropolitan realm. Through these myths, many societies have crystallized strengths, problems and partial solutions for suburbs as for cities. Yet, while these certainties have delimited the transformation of urban/suburban America, they must be called into question there and elsewhere, challenging suburbs as anti-urban spaces. As I have argued, suburbs as places and processes certainly differ from cities (and from other suburbs), yet the qualities of such difference need not pre-

33. Siegeil Lee, "Suburban Blight”, inThe New Republic Online, August 11, 2005 http://www.tnr.com/doc.mhtml?i=w050808\&s=siegel081105.

34. Konstantorakos Myrto, "The film de banlieue: Renegotiating the Representation of Urban Space", in Urban Space and Representation, Balshaw Maria and Kennedy Liam (eds.), London, Pluto Press 2000, p. 131-146, p. 135. 
clude connection and comparison of real value to analysts and citizens. Suburbs as metropolitan creations provide laboratories that reveal - as cities have done for millennia - what people value as humans in groups, creating built environments, balancing justice and opportunity, experiencing and changing place. Thus, the exploration of uncertainties outside the city clarifies both knowledge and values of action for the future of metropolitan spatial justice.

Gary W. McDonogh Growth and Structure of Cities Department, Bryn Mawr College 
SÉGRÉGATION

ET RECONNAISSANCE POLITIQUE 



\section{Californie : de la ségrégation résidentielle à l'injustice politique}

$\mathrm{L}$

'EXIGENCE DE JUSTICE est au coeur de la nation américaine depuis ses fondements, voire ses prémices. Il a en effet été le principal moteur de la révolution. Les abus de la couronne britannique, l'usage de la force pour faire régner l'ordre chez les colons leur était d'autant plus insupportable qu'ils ne bénéficiaient pas d'une juste représentation politique. «No taxation without representation" (pas d'impôt sans représentation politique, slogan politique du révolutionnaire James Otis dès 1764), devint le cri de ralliement de la guerre d'indépendance qui trouvait sa justification dans les enseignements de John Locke et des Lumières: le juste pouvoir du gouvernement émane du consentement des gouvernés; le pouvoir britannique, selon les termes de la déclaration d'indépendance, est « resté sourd à la voix de la justice »; face au despotisme, la rébellion relève du droit et du devoir du peuple à se défendre et établir un gouvernement juste.

Profondément épris de justice, les pères fondateurs veillèrent à garantir la démocratie naissante de toute tyrannie, qu'elle provienne de la majorité, de la minorité ou du président même et d'assurer l'égalité de tous les hommes - ce qui n'incluait certes pas, à l'époque, les femmes et les minorités - par la défense du droit inaliénable à la vie, la liberté et la propriété. Le système politique qu'ils inventèrent en rédigeant la constitution de 1787 fut décrit comme "l'oeuvre la plus merveilleuse jamais conçue par le cerveau de l'homme ». Vénérés comme une "assemblée de demi-dieux ${ }^{1}$ ", les pères fondateurs défendirent ardemment par leurs écrits, rassemblés dans un ouvrage intitulé Le Fédéraliste, un régime inconnu jusque là, une démocratie exceptionnelle sans équivalent dans le monde. Le cœur de ce système politique est la division des trois pouvoirs (législatif, exécutif et judiciaire) et le système de pouvoirs et contrepouvoirs (checks and balances) qui

1. Lacorne Denis, «La philosophie de la Constitution américaine », in Philosophie politique, $\mathrm{n}^{\circ}$ 7, 1995, p. 25-41. 
s'exerce pour garantir les dérives autoritaires ${ }^{2}$. Mais surtout, pour les pères fondateurs, la démocratie repose sur une juste représentation politique des intérêts du peuple, qui ne peut s'exercer qu'à travers l'élection de délégués « honnêtes ", « intègres ", des « hommes de talent » capables de " discerner l'intérêt véritable du pays [...] sans sacrifier à des considérations partielles ou temporaires ${ }^{3} »$. Un tel détachement ne peut s'opérer qu'à l'échelle d'un grand territoire. L'élection est un filtre et non un « miroir représentatif » du peuple, comme l'affirment les anti-fédéralistes, pour qui la recherche du bien commun "n'est pas l'objet de la délibération savante et raisonnée des élites représentatives [mais] le produit d'un marchandage entre groupes et régions dont les intérêts sont difficilement réconciliables ${ }^{4} »$.

La question du territoire était déjà centrale dans la construction d'une représentation politique juste, alors que le pays, en pleine expansion, regroupait des États de forme, de taille et de population extrêmement diverses et en évolution constante. La juste représentation du peuple se fit par l'élection de représentants à l'assemblée, proportionnellement à la population, la juste représentation des territoires, au même titre, conduisit à l'élection de deux représentants par État. La plupart des États calquèrent leur organisation des pouvoirs sur le modèle fédéral afin d'assurer, à l'échelle fédérée, une juste représentation politique des intérêts de tous les citoyens, garante du fonctionnement de la république moderne, juste et égalitaire.

Pourtant, les évolutions démographiques et politiques récentes de la Californie remettent clairement en question le bon fonctionnement de cette démocratie " exceptionnelle ». Les évolutions récentes ne peuvent se comprendre qu'à l'aune d'une analyse géographique précise qui recèle la clé de contradictions politiques majeures apparentes: comment, dans un État à forte majorité progressiste, a-t-on pu révoquer un gouverneur démocrate pour en élire un - star de cinéma, certes - républicain? Ou encore voter les lois de répression de la criminalité parmi les plus dures de l'union (Loi des trois coups) ? Pourquoi l'État à la plus forte proportion de minorités, premier État d'immigration, qui ne possède plus de majorité raciale depuis 2000, a-t-il été le premier à voter une loi privant de services publics les immigrants clandestins (Proposition 187 en 1994)? Ou à démanteler les politiques d'affirmative action (Proposition 209 en 1996) après en avoir été le précurseur? Ou encore l'éducation bilingue (proposition 227 en 1998)?

2. Manin Bernard, Principes du gouvernement représentatif, Paris, Flammarion, 1997.

3. LaCorne Denis, «La philosophie de la Constitution américaine», op. cit.

4. Ibid. 
Pourquoi l'État le plus riche des États-Unis n'est-il pas en mesure d'assurer un enseignement public secondaire de qualité sur l'ensemble de son territoire?

La réponse est nécessairement complexe et la Californie s'est souvent trouvée à l'avant-garde de tendances qui ont fini par s'étendre à nombre d'autres États ${ }^{5}$. Mais la nouvelle géopolitique de la Californie révèle avant tout l'accroissement d'inégalités socio-spatiales qui, en raison des évolutions du système politique de l'État, conduisent à une représentation politique injuste d'une partie des citoyens et des territoires. Notre hypothèse est donc que la ségrégation résidentielle conduit à l'injustice politique, source des contradictions apparentes que nous venons d'évoquer mais aussi du renforcement, en retour, des inégalités socio-spatiales.

\section{DiVERSITÉ ET SÉGRÉGATION RÉSIDENTIELLE En CALifornie}

Soumise à une immigration massive, des migrations internes importantes et une très forte mobilité de la population, la Californie a vu sa population considérablement augmenter et devenir plus diverse et plus démocrate au cours des dernières décennies. En 2006, plus de $57 \%$ des Californiens étaient des minorités - soit Latinos, Asiatiques ou AfricainsAméricains. En 2000, d'après le recensement, on comptait 47,3 \% de Blancs, 32,4 \% d'Hispaniques/Latinos, 6,5 \% de Africains-Américains/Noirs, $11 \%$ d'Asiatiques, 0,6 \% d'Indiens-Américains et 1,9\% de «multirace ». Alors qu'ils étaient encore 66,6 \% en 1980, les Blancs ne devraient plus constituer plus que $26 \%$ de la population de l'État en 2050. Pourtant, au cours de la dernière décennie, comme nous le démontrerons par une analyse quantitative, la ségrégation résidentielle a augmenté, alors qu'elle est en décroissance dans l'ensemble du pays. Les Californiens tendent ainsi à se regrouper clairement, volontairement ou non, dans des zones résidentielles entre personnes de même niveau socio-économique, de même appartenance ethnique et de mêmes affinités politiques.

Alors que les zones de mixité sont de plus en plus nombreuses, notamment dans les grands centres urbains, de poches de très forte homogénéité socio-économique et/ou raciale persistent ou se créent dans les territoires jusqu'ici très peu peuplés de l'intérieur de l'État. D'un côté, les comtés d'Orange ou la San Gabriel Valley, qui jusqu'à récemment étaient les ban-

5. Douzet Frédérick et Cain Bruce, «Le paradoxe multiculturel de la Californie », in Politique américaine, n 9, hiver 2007-2008, p. 13-31. 
lieues blanches de Los Angeles, sont désormais largement peuplées d'immigrants hispaniques et asiatiques, comme bien d'autres zones autrefois presque exclusivement blanches. Quasiment tous les anciens ghettos noirs sont devenus au moins partiellement latinos. Dans le même temps, des quartiers dotés d'une importante communauté latino sont devenus plus homogènes, à savoir presque exclusivement latinos. De nombreux Californiens ont accueilli très favorablement cette diversité et ré-emménagé dans les villes-centre pour profiter de quartiers culturellement dynamiques et du foisonnement des restaurants ethniques. D'autres, au contraire, ont cherché refuge dans des zones de forte homogénéité, notamment à l'intérieur de l'État, au point de remettre en question la traditionnelle division régionale nord-sud pour conduire à l'émergence d'une division est-ouest ${ }^{6}$.

Face aux problèmes posés par la croissance de la population, par l'afflux d'étrangers mais aussi par la congestion automobile, l'augmentation des prix du logement, la dégradation du niveau des écoles publiques ou les violences urbaines, nombre de Californiens partent s'installer au-delà des banlieues, dans des villes-champignons en périphérie lointaine des centres, que les urbanistes n'appellent plus suburbs mais exurbs. À la recherche d'une meilleure qualité de vie, d'écoles de qualité pour leurs enfants ou d'une plus grande homogénéité sociale ou ethno-raciale, ces Californiens n’hésitent pas à effectuer un trajet domicile-travail supérieur à une heure pour installer leur famille dans de bonnes conditions. D'autres quittent l'État, qui connaît désormais un solde migratoire interne négatif. La croissance de population est aujourd'hui seulement liée à l'immigration et l'accroissement naturel. Entre 1990 et 2000, la Californie a perdu plus d'un million de résidants blancs, partis pour la plupart en Arizona, dans le Nevada ou le Colorado ${ }^{7}$.

Un bon exemple est la ville de Modesto (comté de Stanislaus), dans la Central Valley, à une heure et demie de route de Sacramento et deux heures de San Francisco. La population a plus que doublé depuis les années 1980 et malgré les évolutions démographiques de l'État, la ville et ses environs maintiennent un pourcentage de population blanche nettement supérieur à la moyenne de l'État (10 points de pourcentage). Plus au nord-est, dans la région montagneuse, les comtés sont blancs à 80 voire plus de $90 \%$. Ils se

6. Douzet Frédérick et Miller Kenneth P., «California's East-West Divide », in The New Political Geography of California, Douzet Frederick, Kousser Thad, MiLLer Kenneth P. (dir.), Berkeley, CA, Berkeley Public Policy Press, 2008.

7. Perry Marc J., State-to-State Migration Flows, 1995-2000, Census Special Report 2000, U.S. Bureau of the Census, août 2003. 
diversifient beaucoup plus lentement que le reste de l'État. Sur la côte, des villes comme Sausalito (comté de Marin), dans la Baie de San Francisco, restent à très forte majorité blanche, malgré la présence croissante d'immigrants dans le reste du comté. Du coup, le décalage entre la proportion de Blancs dans la ville et celle dans l'État s'est accrue, pour atteindre 34 points de pourcentage.

Pour vérifier nos hypothèses, nous avons donc cherché à mesurer si l'accroissement de la diversité de la population conduit à plus ou moins de ségrégation résidentielle. L'une des difficultés, pour la Californie, est l'absence de groupe dominant par rapport auquel mesurer la ségrégation de tel ou tel autre groupe, les Blancs représentant désormais moins de la moitié de la population. L'autre défi est la prise en compte de la dimension spatiale de la ségrégation, afin de comprendre si les habitants se regroupent plutôt en fonction de frontières régionales, municipales ou de quartier. Nous avons eu recours à l'indice « $\mathrm{H}$ » de Theil qui permet d'établir un indice de diversité pour l'État de Californie et de mesurer ensuite le niveau de diversité de chacune de ses composantes spatiales par rapport à l'indice de diversité de l'État ${ }^{8}$. Cette méthode permet d'étudier la ségrégation en tenant compte de plusieurs groupes, plusieurs variables et plusieurs échelles géographiques. Elle a par ailleurs l'avantage d'être parfaitement additive. On peut ainsi mesurer la ségrégation à l'échelle de l'État et calculer la contribution de chaque échelon géographique (région, comté, municipalité, quartier) au total de l'État.

Les résultats montrent que l'accroissement de la diversité de la population ne signifie pas plus de diversité pour chacune de ses régions ou de ses quartiers. Les changements ne se produisent pas à la même vitesse ni dans les mêmes proportions selon les zones géographiques. Certaines ont connu des changements drastiques, d'autres ont été peu affectées. En d'autres termes, la diversification n'a pas mis fin aux dynamiques ségrégatives. $\mathrm{Au}$ contraire, la ségrégation tend à se renforcer. La ségrégation raciale a augmenté de 6,9\% entre 1990 et 2000 et la ségrégation politique (démocrates et républicains) de 4,7\%. De la même façon, elle s'est accrue aux deux

8. Reardon Sean F., Firebaugh Glenn, « Measures of multigroup segregation », in Sociological Methodology, vol. 32, no 1, 2002, p. 33-67; Fischer Claude S., StockMAYer Gretchen, Stiles Jon, et Hout Michael, «Distinguishing the geographic levels and social dimensions of U.S. Metropolitan Segregation ", in Demography, vol. 41, $\mathrm{n}^{\circ}$ 1, février 2004, p. 37-59; Iceland John Iceland, Douzet Frédérick, " Mesurer la ségrégation raciale et ethnique dans les milieux résidentiels », in Hérodote, $\mathrm{n}^{\circ} 122,3^{\mathrm{e}}$ tr. 2006, p. 25-43. 
extrêmes de l'échelle de revenus: $+4,9 \%$ pour le quintile des plus hauts revenus, $+1,8$ pour les plus bas revenus.

Le deuxième résultat montre que le moteur principal de la ségrégation résidentielle est l'auto-ségrégation des Blancs et des populations aux revenus les plus élevés, qui prend soit la forme d'une « fuite » (white flight) vers les exurbs ou d'un cloisonnement par le biais des frontières municipales. La ségrégation des Blancs a augmenté dans le même temps de 16,9\%, particulièrement au niveau municipal $(+28,6 \%$ contre $12,3 \%$ à l'échelle de la région, $4,1 \%$ du comté et $10,8 \%$ du quartier). Ce cloisonnement municipal se vérifie toutes races confondues: $+13,3 \%$ contre $10,4 \%$ pour le comté, $4,2 \%$ pour la région et $2,0 \%$ pour le quartier.

En revanche, le taux de ségrégation a fortement diminué pour les Noirs $(-17,4 \%)$, en raison notamment de leur plus grande mixité avec les Latinos. Les Asiatiques ont également vu leur ségrégation diminuer (-16,5\%) alors qu'elle se renforce pour les Latinos $(+4,7 \%)$.

Cette ségrégation résidentielle renforce des inégalités socio-spatiales perçues comme d'autant plus injustes que ses conséquences politiques les perpétuent voire les aggravent. En effet, la ségrégation résidentielle renforce les inégalités politiques créées par le système de double démocratie en Californie (représentative et directe) et accroît la compétition entre les territoires, au profit de ceux qui cumulent les avantages et le plus fort pouvoir politique.

La différence de pouvoir politique entre les territoires entraine ainsi des disparités importantes, des rivalités de pouvoir majeures et un accès inéquitable aux ressources de développement, ce qui peut être considéré comme une première dimension d'injustice spatiale. En effet, quelles que soient les définitions de la justice que l'on puisse retenir, «la justice vise d'abord à réduire, abolir, ou rendre acceptable l'inégalité socio-économique $^{9} »$. La ségrégation résidentielle n'est pas intrinsèquement injuste en ce qu'elle résulte du libre choix des habitants de vivre « entre soi » en fonction de leurs moyens respectifs et de leurs affinités sociales, raciales ou politiques. Elle le devient, en revanche, lorsqu'elle enferme des populations dans des situations dont le choix ne leur appartient pas et qui les privent d'accès équitable aux ressources économiques, sociales et politiques, conditions essentielles de leur mobilité socio-économique et d'une réelle égalité des chances. Or la ségrégation résidentielle, en Californie, nourrit le repli

9. Appel à communications du colloque « Justice et injustice spatiales », Université Paris Ouest Nanterre La Défense, mars 2008. 
sur soi et la défiance envers les institutions politiques de l'État, décourageant notamment les électeurs de financer des services publiques collectifs, ce qui renforce, en retour, les inégalités territoriales et donc les processus de ségrégation spatiale. Le système politique californien accroît ainsi les injustices spatiales liées à la ségrégation résidentielle.

Trois facteurs permettent d'expliquer que le système politique californien favorise un accroissement des inégalités spatiales liées à la ségrégation résidentielle, aboutissant ainsi à une représentation politique injuste d'une partie de la population: une fragmentation urbaine qui encourage la compétition entre les territoires; les revers de la démocratie directe; les limites du redécoupage électoral.

\section{FragmentATION ET COMPÉTITION TERRITORIALE}

En raison de la grande décentralisation des pouvoirs et de la forte fragmentation territoriale urbaine, l'autonomie des gouvernements locaux favorise une intense compétition entre les territoires. Dans un contexte d'immigration massive, de forte mobilité de la population et de concurrence économique accrue, certains gouvernements locaux sont à même d'élaborer des règles visant à encourager ou empêcher l'installation de certains types de populations, équipements, activités économiques, selon qu'ils soient considérées comme désirables ou non. Or ce sont les territoires qui concentrent déjà le plus d'avantages économiques et sociaux qui sont à même de mobiliser le plus efficacement les ressources pour défendre leurs intérêts spécifiques, au détriment des territoires défavorisés.

L'analyse multiscalaire est ici indispensable pour comprendre comment s'organisent les rivalités entre groupes politiques sur des territoires et entre territoires. L'organisation des pouvoirs au niveau de l'État s'articule principalement entre l'État fédéré et le gouvernement local (la municipalité), qui peut comprendre quelques milliers d'habitants ou quelques millions. L'État est cependant subdivisé en comtés qui possèdent un certain nombre de pouvoirs, notamment celui d'organiser les élections ou d'administrer les hôpitaux, et dont le pouvoir le plus intéressant en termes de rivalités territoriales est celui d'administrer les territoires qui n'ont pas encore formé de gouvernement local (non incorporés), soit en raison de leur petite taille, de leur développement récent, ou en raison de leur absence d'organisation politique. Bien que n'ayant pas d'autorité en matière de développement urbain sur les gouvernements locaux, le comté est de fait partie intégrante de l'organisation du développement puisqu'il administre tous les territoires en périphérie des villes sur lesquels des habitants ou des entreprises 
sont susceptibles de venir s'installer. Il administre même des territoires au sein de certaines villes, comme Los Angeles, qui s'est formée en annexant des territoires voisins, laissant au sein de ses frontières des territoires non incorporés ou des villes déjà formées, dotées d'un gouvernement élu indépendant. Les districts spéciaux, enfin, font également partie de l'équation sur ces territoires. Ils sont en général formés dans le but de gérer un aspect particulier du développement (le réseau d'eau potable, les écoles d'un territoire, le réseau de transports publics...). Leurs frontières dépendent en partie de leur activité mais aussi de leur ancienneté et des rivalités de pouvoir politiques existant sur leur territoire. Ils sont par ailleurs très dépendants dela coopération des gouvernements locaux pour leur fonctionnement et sont souvent gérés par un comité composé de membres élus ou nommés par les maires. Il est par exemple difficile de prolonger une ligne de métro ou d'étendre le réseau ferroviaire local si les communes traversées s'y opposent.

On compte 182 gouvernements locaux pour la région métropolitaine de Los Angeles (567 pour celle de Chicago!) et presque autant de casernes de pompiers, de départements de police et d'élus soucieux de conserver leur siège. Les tentatives de mettre en place une échelle métropolitaine de gouvernement se heurtent à de farouches résistances. Au contraire, la tendance est à la création de communautés fermées qui se protègent, derrière de hauts murs et une réglementation stricte, des nuisances potentielles en provenance des territoires environnants. Exemple extrême, des leaders politiques de San Fernando Valley, à Los Angeles, réussirent à soumettre au vote en 2002 une demande de sécession, afin de contrôler le développement et les revenus financiers de leur territoire, et de s'extraire d'une municipalité trop grande, une rébellion contre le big government. La proposition fut rejetée par les habitants de Los Angeles à $67 \%$ mais fut approuvée à une courte majorité (51 \%) par les habitants de San Fernando Valley.

Ces résistances sont en partie fondées sur les représentations que les acteurs politiques se font d'un échelon de pouvoir métropolitain, qu'ils perçoivent non pas comme une décentralisation des pouvoirs de l'État, comme cela peut être le cas en France, mais bien comme une recentralisation des pouvoirs qui prive les gouvernements locaux d'une autonomie qu'ils défendent ardemment. Il s'agit donc d'une logique complètement inverse à celle des États fortement centralisés, centrée sur la défense des intérêts particuliers de petits territoires. Et dans la promotion de cette forte autonomie locale, on retrouve bien des arguments développés par les antifédéralistes à l'époque de l'élaboration de la Constitution de 1787, puis de la campagne qui s'en est suivie pour sa ratification par les 13 États fonda- 
teurs de la nation américaine. La défiance à l'égard de l'État central repose sur la conception développée par Montesquieu en 1748 selon laquelle une démocratie ne pourrait fonctionner que dans le cadre d'une " petite république », afin que les représentants soient proches du peuple et partagent ses préoccupations. Sacramento, capitale politique de l'État, est ainsi souvent décrite par les représentants locaux comme un lieu de pouvoir éloigné, déconnecté des enjeux locaux et des besoins des populations locales. Les gouvernants locaux accusent souvent l'État de ne pas répondre à ces besoins et de ne pas « rendre » sous forme de services efficaces, l'argent versé par les contribuables. L'individualisme et la peur de la tyrannie marquent aussi profondément les relations entre État et gouvernements locaux et expliquent que parmi ces derniers, beaucoup cherchent à préserver leur pouvoir afin de ne subir ni nuisance, ni entrave à leur prospérité de la part du gouvernement central, tout en exigeant par ailleurs d'obtenir la part la plus importante possible des investissements de l'État. La logique qui prévaut est donc celle de la maximisation des pouvoirs politiques et des ressources sur des territoires qui se trouvent ainsi en forte compétition.

Cette compétition exacerbée entre les territoires pour attirer des ressources et empêcher l'installation de populations ou équipements « indésirables" se traduit notamment par la multiplication des conflits géopolitiques liés aux questions d'aménagement et dans lesquels la population en mesure de mobiliser d'importantes ressources s'implique de plus en plus, exerçant une pression majeure sur les élus et participant souvent directement au processus de décision ${ }^{10}$. L'enjeu est de taille pour les élus, au-delà de leur seule réélection, car les Californiens votent facilement avec leurs pieds.

Or ces populations qui partent s'installer en lointaine périphérie sont avant tout celles qui en ont les moyens financiers, ce qui a tendance à aggraver la ségrégation socio-économique, mais aussi celles qui ont le plus fort pouvoir électoral, et qui s'en servent pour préserver les atouts et l'autonomie du territoire sur lequel elles se sont installées. Le maire de Murietta, ville champignon à mi-chemin entre Los Angeles et San Diego, fut révoqué en 2005 pour une mauvaise gestion du développement: les habitants lui reprochèrent essentiellement d'avoir laissé construire de petits immeubles à proximité de résidences pavillonnaires. D’autres communes usent de lois de zonage imposant une taille minimale des propriétés pour sélectionner

10. Miller Gary J., Cities by Contract: The Politics of Municipal Incorporation, Cambridge (Mass.), MIT Press, 1981. 
les habitants et offrent des réductions d'impôts pour attirer commerces et entreprises.

Les acteurs politiques comme les électeurs en Californie agissent en fonction de leurs intérêts spécifiques, bien loin des principes de justice chers à John Rawls ${ }^{11}$, approuvés par des individus «libres et rationnels », placés dans la "position originelle derrière un voile d'ignorance ", inconscients de leur propre statut dans la société, ou leur classe, sexe ou race. En l'absence d'un niveau régional de gouvernement, qui pourrait instaurer des mécanismes de péréquation (comme en Europe ou au Canada), les populations des territoires déjà défavorisés ne bénéficient ainsi pas d'une représentation juste de leurs intérêts.

\section{LES REVERS DE LA DÉMOCRATIE DIRECTE}

Cette compétition territoriale est aggravée par le fait que l'intérêt général peine à être défendu à l'échelle de l'État par la démocratie représentative, largement court-circuitée par la démocratie directe.

La Californie fit le choix de la démocratie directe dès 1911 en dotant ses électeurs d'un processus de référendum pour ratifier des lois proposées par la législature, ainsi qu'une procédure de révocation et de mesures d'initiative populaire. Ces dernières permettent à un petit groupe de citoyens motivés, capables de réunir suffisamment de signatures, de mettre au vote une proposition de loi qu'il a élaborée. Elle existe au niveau de l'État fédéré - dans 24 États aux États-Unis - mais aussi au niveau local en Californie.

D’inspiration progressiste, la réforme institutionnelle visait à protéger la souveraineté du peuple face au pouvoir des «machines politiques». Elle est, depuis, devenue le vecteur de la frustration d'électeurs face à l'immobilisme ou la trop grande puissance de l'État. Les mesures d'initiative populaire furent très peu utilisées au début du siècle. Elles sont aujourd'hui devenues, pour certains groupes de citoyens, le meilleur moyen de défendre leurs intérêts particuliers, voire un outil de contournement de la législature en place par le gouverneur. En 2005, en effet, Arnold Schwarzenegger avait vainement tenté de court-circuiter le pouvoir législatif, hostile à ses projets de loi, en soutenant des mesures d'initiative populaire. C'est d'ailleurs en raison de la déconcertante facilité d'utilisation de la démocratie directe que le gouverneur Gray Davis a pu être révoqué et Arnold Schwarzenegger élu

11. Rawls John, Théorie de la Justice, Audard Catherine (trad.), Paris, Éditions du Seuil, 1987. 
gouverneur dans la foulée, par la même élection, au mépris de toute investiture par l'appareil de parti ${ }^{12}$.

Là encore, la dimension spatiale est fondamentale. Au sein des communautés immigrantes, la proportion de résidents qui ne possèdent pas la nationalité américaine est élevée et le taux d'électeurs, par conséquent, faible. En revanche, les populations qui arrivent d'autres États pour des raisons professionnelles ou qui déménagent au sein de l'État comportent une forte proportion d'électeurs. Les choix résidentiels des populations en mobilité ont donc un impact direct sur le pouvoir politique des territoires sur lesquels elles s'installent.

Cette situation conduit à l'existence de deux types d'électorat: d'une part, un électorat de démocratie directe qui s'exprime à l'échelle de l'État, dominé par les territoires de classes moyennes et aisées dotées d'un fort pouvoir électoral. Cet électorat a fréquemment recours à des mesures d'initiative populaire qui défendent des intérêts spécifiques et imposent des contraintes budgétaires de plus en plus lourdes à l'État; d'autre part, un électorat de démocratie représentative, basé sur le découpage des circonscriptions législatives, qui reflète mieux la composition de la population de Californie avec l'élection d'un représentant par circonscription et ce, quel que soit le degré de participation politique de cette circonscription. La croissance rapide du nombre d'élus latinos au cours de la dernière décennie - encouragée par le renouvellement de la classe politique depuis l'adoption d'une limite à deux mandats électifs - atteste ainsi de la présence de plus en plus nombreuse et répandue de cette minorité en Californie. Elle offre ainsi une représentation relativement juste de la population, même si les minorités récentes restent sous-représentées au sein de l'électorat, en raison de leurs faibles taux de citoyenneté et de participation électorale.

Les mesures d'initiative populaire mobilisent un électorat partiel, peu représentatif de la population dans son ensemble, qui est parfois en totale contradiction avec la politique défendue par la législature et qui impose des lois extrêmement contraignantes pour le budget de l'État. L'exemple emblématique est la Proposition 13, surnommée "révolte des contribuables ", initiée par des associations de propriétaires de Californie du Sud, qui a littéralement vidé les caisses de l'État en plafonnant l'impôt foncier à $1 \%$ de la valeur du bien et en limitant strictement son augmentation. Tous les ser-

12. Chandler William M. et Kousser Thad, «L'ascension, la chute et la résurrection du gouverneur Arnold Schwarzenegger ", in Politique américaine, n 9, hiver 2007-2008, p. 47-64. 

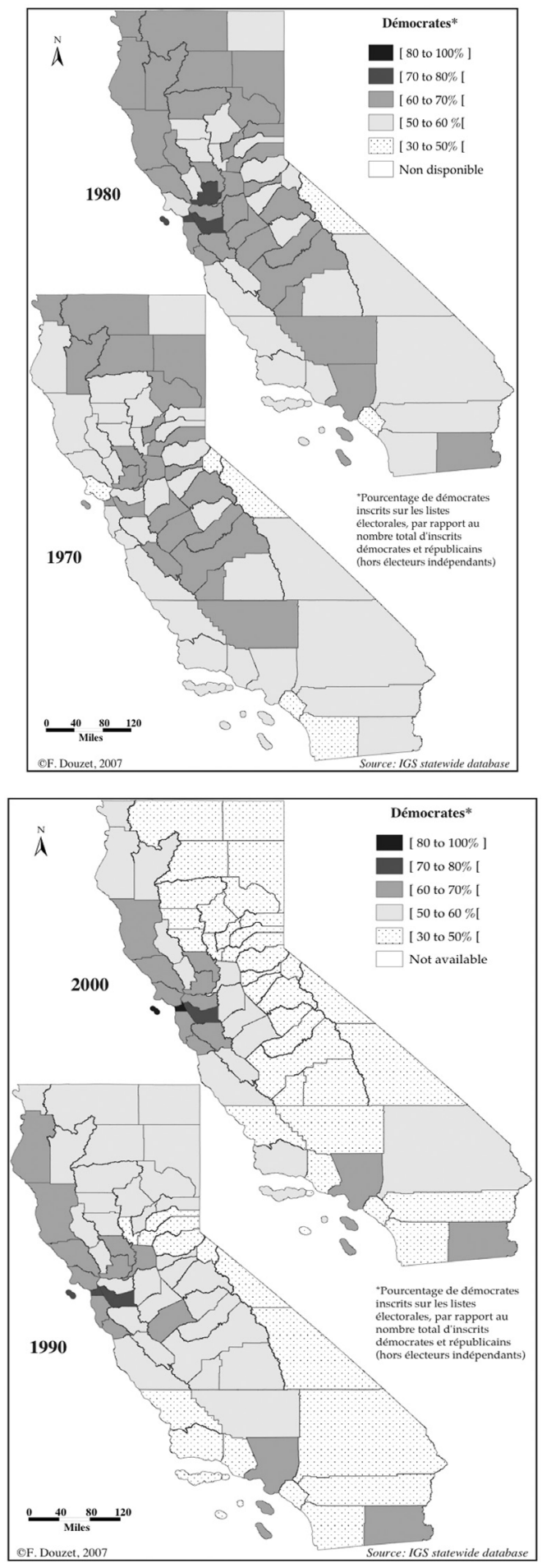

Fig. 1. L'évolution du vote démocrate en Californie entre 1970 et 2000 
vices publics de l'État en ont souffert, à commencer par les écoles publiques dont le financement a chuté du $5^{\mathrm{e}}$ au $44^{\mathrm{e}}$ rang national sur les 50 États.

Les Blancs républicains de classe aisée sont surreprésentés au sein de l'électorat de démocratie directe et parmi les initiateurs de propositions qui nécessitent des ressources politiques et financières importantes. Les cartes de quelques propositions clé sont extrêmement explicites: la proposition de révocation du gouverneur Gray Davis en 2003 a été approuvée dans tous les comtés de l'intérieur de l'État, majoritairement républicains mais a été rejetée par tous les comtés de la côte ouest, région nettement plus peuplée, plus diverse et démocrate. Il en va de même de la proposition 209 en 1996, de démantèlement des politiques préférentielles envers les minorités, ou encore de la tentative de réforme de la « loi des trois coups » en 2004, qui, par l'imposition de peines-plancher de 25 ans au troisième délit ${ }^{13}$, grève sévèrement le budget de la Californie en accroissant la population carcérale et soulève nombre de questions éthiques.

La démocratie représentative, qui puise sa légitimité dans un découpage territorial visant à refléter au mieux les intérêts de la population, se trouve ainsi largement concurrencée, voire court-circuitée. Et ce malgré d'intenses débats sur le redécoupage des circonscriptions, censé corriger les effets de l'injustice spatiale en offrant une représentation juste de la population et des minorités, mais soupçonné de favoriser la sécurisation politique des sièges de la législature et d'accroître ainsi la ségrégation spatiale et politique.

\section{LES LIMITES DU REDÉCOUPAGE ÉLECTORAL}

La loi sur le droit de vote de 1965 - et notamment l'amendement de 1982 - impose un redécoupage électoral tous les dix ans, après chaque recensement, afin de garantir une juste représentation de la population, particulièrement des minorités. Les débats sont parfois houleux à l'échelle municipale, comme ce fut le cas à Oakland en 1992, tant les enjeux de la représentation politique sont importants ${ }^{14}$. Certains découpages particulièrement alambiqués ont été invalidés par les cours de justice, dont la Cour suprême (voir notamment Shaw v. Reno). Maximiser la représentation des minorités conduit parfois à des découpages qui empiètent sur des territoires protégés par des élus ou des communautés. L'objectif d'équité

13. À condition que l'une des deux premières ait comporté un caractère violent.

14. Douzet Frédérick, "The Geopolitical Transition of Oakland », in The New Political Geography of California, op. cit. 
peut ainsi conduire à des entorses à l'égalité formelle, une inégalité, d'après John Rawls, pouvant être juste tant qu'elle est profitable à l'ensemble de la société. Le débat a rejoint celui des politiques d'affirmative action, ce « mal nécessaire", selon la formule célèbre du juge Blackmun, hautement contesté dans les années $1990^{15}$.

Par ailleurs, devant la polarisation extrême de l'État Californie, et sachant que le taux de réélection des représentants est de plus de $90 \%$, les pratiques de redécoupage électoral firent l'objet d'une vive remise en question dans les années 1990. Les élus furent accusés de troquer des parties de leur circonscription pour assurer leur réélection, et par-là de créer des poches d'homogénéité politique quasiment inaltérables. Soucieux de conquérir plus de sièges, les républicains ont cherché à transférer la responsabilité du redécoupage à un conseil de neuf juges, s'estimant injustement représentés au sein de la législature actuelle où le redécoupage est entre les mains d'élus qui cherchent avant tout la préservation de leur circonscription.

Pourtant, les études montrent que la ségrégation résidentielle est si forte que les pratiques visant à créer des districts où les minorités sont majoritaires ou bien à accroître la compétitivité politique des circonscriptions ne sont efficaces qu'à la marge. Tout au plus, les pratiques des élus renforcent des tendances déjà existantes ${ }^{16}$.

\section{ConcLusion}

Bien que la législature californienne reflète relativement bien la population de l'État, l'écart entre la composition de l'électorat et celui de la population totale reste très important. Or le système de double démocratie et la fragmentation territoriale de l'État accentuent cette injustice. Ils confèrent un pouvoir politique supérieur aux territoires et aux populations les mieux dotées, ce qui leur permet d'infléchir sérieusement les politiques de l'État en fonction de leurs intérêts spécifiques et de maximiser leurs ressources dans un contexte de compétition accrue entre les territoires. La mobilisation politique des élus et leaders communautaires locaux les place en rivalité directe avec le gouvernement de l'État envers lequel ils affichent une

15. Calvès Gwénaële, L'Affirmative Action dans la jurisprudence de la cour suprême des États-Unis. Le Problème de la discrimination positive, Paris, LGDJ, 1998, p. 78.

16. Cain Bruce, Hui Iris, McDonald Karin, « Sorting or Self-Sorting: Competition and Redistricting in California? ", in The New Political Geography of California, Berkeley, op. cit. 
grande défiance, justifiant leur désolidarisation financière et politique par les piètres performances de l'État en matière de services publics. En retour, la multiplication des mesures d'initiative populaire a profondément grevé le budget de la Californie et limité sa capacité d'action.

On retrouve ainsi, au sein même de l'État de Californie, des tensions similaires à celles qui ont marqué les débats fondateurs lors de l'élaboration de la Constitution des États-Unis: le clivage opposant les fédéralistes, tenants d'une démocratie représentative reposant sur l'équilibre des pouvoirs, aux anti-fédéralistes, soucieux de la préservation d'un pouvoir local fort, resurgit. Chaque camp croyait ainsi défendre une représentation politique juste, condition essentielle de la démocratie.

Frédérick DouzeT

Institut français de géopolitique,

Université Paris 8

\section{BIBLIOGRAPHIE COMPLÉMENTAIRE}

Chandler William M. and Kousser Thad, " Governors, Geography and Direct Democracy: the Case of Arnold Schwarzenegger ", in The New Political Geography of California, Douzet Frederick, Kousser Thad, Miller Kenneth P. (dir.), Berkeley (CA), Berkeley Public Policy Press, 2008.

ICELAND John, "Beyond Black and White. Metropolitan residential segregation in multi-ethnic America ", Social Science Research, $n^{\circ} 33,2004$, p. 248-271.

Vergniolle de Chantal François, Fédéralisme et antifédéralisme, Paris, PUF, « Que sais-je?», 2005. 



\title{
Recognizing Justice: Identities and Policies in Beer Sheva
}

\begin{abstract}
"What we ask from you is simple: just observe the law; if you do this, everybody will benefit: you will have well planned, serviced and recognized towns, and we'll safeguard the last tracts of vacant land for the Jewish people around the world, and particularly for those who stayed for the time being in the ex Soviet Union, for a possible day of crisis." Ze'ev Boym, Minister for Housing, Beer Sheva, 14 June 2006.
\end{abstract}

$\mathrm{T}$

He CONTEXT IS THE UNRESOLVED LAND and planning disputes between the Bedouin Arabs surrounding the city of Beer Sheva and the Israeli state. The minister asks the indigenous Bedouin in no uncertain terms to leave their ancestors land, where they reside in "unrecognized" (and in the eyes of most Israeli planners "illegal") villages and towns, and relocate into modernized, legal, and well-serviced localities.

Beyond the colonialist disregard of indigenous rights embedded in the minister's vision, he unwittingly exposed a dilemma about recognition widely accepted as "positive" in discussions about spatial justice. His comments invoked a type of recognition which works against, not for, group rights and social justice. At the same time, he extended privileged recognition to potential Jewish immigrants. This differentiation provides a puzzling aspect to our thinking about urban justice and group rights rarely addressed by planning theorists. Should we, can we, "open up" the Pandora Box of recognition?

This chapter explores the relations between recognition and justice. We analyze the treatment of various immigrant and indigenous groups by state and urban authorities, and highlight the manner in which various types of recognition guide urban policy. Our central argument takes issue with the mainstream view of recognition as a necessarily positive element in the pursuit of urban justice. Instead, we view it as a multi-faceted socio-politi- 
cal process, ranging between positive affirmation, marginalizing indifference and exclusive hostility, with a multitude of possibilities in between these poles. We argue that the "gradients" of recognition are linked to significant changes in the urban fabric. Not only are they clearly associated with socioeconomic (class) stratification, but also with phenomena we identify as new "urban colonialism" "creeping urban apartheid", and the formation of "gray" (informal) spaces.

We thus seek to advance the discussion on spatial justice, by "opening up" the rubric of "recognition". We maintain that a more sophisticated and critical understanding of this concept is needed, and that recognition, or lack of, may enhance or harm social and spatial justice. Recognition should thus be viewed as a continuum, and governing bodies should be aware of the damaging possibilities of marginalizing indifference or exclusive hostility, as much as the positive possibilities of affirmative recognition.

Following a theoretical discussion, a conceptual scheme is used to analyze the impact of planning on various groups in the Beer Sheva region. We trace the formulation of differential policy: affirmative recognition is extended to "Russian" immigrants (denoting Russian- speakers hailing from the former USSR); "marginalizing indifference" is prevalent in the policies towards Mizrahim (Jews arriving from the Middle East and their descendents); and hostile recognition is evident vis-a-vis most Arabs in the region. The claims of Palestinian refugees are totally absent from the planning discourse, while potential Jewish migrants, as noted in the minister's statement, cast a distant but ever-present shadow over the allocation of space in the region.

This chapter aims to rethink social justice under conditions of variegated recognition. We briefly suggest below the "right to the city ${ }^{1 "}$ as a possible guiding principle for combining recognition and spatial justice, while avoiding the colonial pitfalls of planning for different types of recognition. This requires politicization and specialization of the abstract concept, and critical engagement with mainstream liberal literature on urban justice. 


\section{Planning, Justice and Difference}

Until the 1970's the profession of planning was described as the redeemer of the industrial city by offering new social moral and professional zeal ${ }^{2}$. During the 1970's the attention was drawn to the structural links between planning, economic structure, development capital, and neglected social needs ${ }^{3}$. This critical analysis was the basis on which an "urban" justice literature began to emerge, in an attempt to rethink the links between space, development, power and planning ${ }^{4}$.

During the 1980s and 1990s, new claims for a just city began to appear. In the main, three related and partially overlapping perspectives informed these challenges: identity, feminism, and postmodernism ${ }^{5}$.

Other studies highlighted the close links between ethno-nationalism, religion, the state, and the making of cities and regions ${ }^{6}$. This is particularly so in "ethnocratic" regimes, which work to enhance the position of a dominant ethnic group, while actively marginalizing minorities and peripheral ethno-classes ${ }^{7}$. Other studies have shown the centrality of race to urban structure, segregation and hence to notions of corrective justice and improved terms of collective coexistence ${ }^{8}$.

2. Hall Peter, Cities of Tomorrow, Berkeley, Basil Blackwell, 1988.

3. Castells Manuel, The Urban Question, London, Arnold, 1978; Hague Cliff, The Development of Planning Thought, London, Hutchinson, 1984; BADCOCK Blair, Unfairly Structured Cities, Oxford-London, Blackwell, 1984.

4. Harvey David, Social Justice and the City, London, Arnold, 1973; Castells Manuel, The Urban Question, op. cit.

5. Young Iris Marion, Justice and the Politics of Difference, New Jersey, Princeton University Press, 1990; Sandercock Leonie, Mongrel Cities of the 21st Century, New York, Continuum Press, 2003.

6. Bollens Scott, Urban Peace-Building in Divided Societies, Boulder, CO and Oxford, Westview Press, 1999; Yiftachel Oren, "State Policies, Land Control and an Ethnic Minority: the Arabs in the Galilee, Israel", in Society and Space, vol. 9, 1991, p. 329-362; Thомаs Huw, "Race, Public Policy and Planning in Britain”, in Planning Perspectives, $\mathrm{n}^{\circ}$ 10, 1995, p. 125-148.

7. Yiftachel Oren, Ethnocracy: Land and Identity Politics in Israel/Palestine, Philadelphia, Pennpress, University of Pennsylvania, 2006; Kedar Sandy, "On the Legal Geography of Ethnocratic Settler States: Notes Towards a Research Agenda", in Law and Geography Current Legal Issues, Holder Jane, Harrison Carolyn (ed.), Oxford, Oxford University Press, 2003, p. 401-442.

8. Thomas Huw, "Race, Public Policy and Planning in Britain", op. cit.; Sandercock Leonie, Mongrel Cities of the 21st Century, op. cit. 
The main consequence of this discussion was the growing introduction of new categories and entities into the vocabulary and imagination of the "just city" concept, most notably "recognition", "diversity", "difference" and "multiculturalism".

\section{Recognition and Redistribution}

Nancy Fraser's now classic essay ${ }^{10}$ re-conceptualized much of the above discussion, by arguing that claims for justice can be organized on two major structural axes - distribution and recognition, which operate in constant interaction, but are not reducible to one another. Within each axis, she added, approaches to justice range between "affirmative" and "transformative" measures. Affirmative measures denote relatively cosmetic steps with a temporary effect on injustices, which tend to reproduce in the long-run the unequal capitalist/nationalist and male dominated settings. Transformative measures, on the other hand, have more profound effects, by challenging the social systems that produce the hierarchical order of classes, genders, "races" and ethnic entities. Fraser's intervention and the debates that ensued ${ }^{11}$, further entrenched recognition as a major category in the pursuit of social and urban justice ${ }^{12}$.

Fraser's work included a profound critique of mainstream liberalism and of the increasingly popular procedural approaches to social justice ${ }^{13}$. Furthermore, she addressed the returning to structuralism, following a period in which Western theoretical debates were dominated by postmodernism and post-structuralism ${ }^{14}$ who focused on micro investigations of the com-

9. TAYlo R Charles, “The Politics of Recognition", in Multiculturalism: Examinnig the Politics of Recognition, Gutman Amy (ed.), Princeton, Princeton University Press, 1992, p. 25-73; Kyмlicka Will, Multicultural Citizenship: A Liberal Theory of Minority Rights, Oxford, Clarendon Press, 1995.

10. Fraser Nancy, "Recognition or Redistribution? A Critical Reading of Iris Young's Justice and the Politics of Difference", in Journal of Political Philosophy, vol. 3, 1996, p. 166-80.

11. Young Iris Marion, Intersecting Voices: Dilemmas of Gender, Political Philosophy and Policy, New Jersey, Princeton University Press, 1997; Fraser Nancy, "Rethinking Recognition", in New Left Review, vol. 259, 2000, p. 107-120.

12. SANDERCOCK Leonie, Mongrel Cities of the 21st Century, op. cit..

13. Fraser Nancy, "Recognition or Redistribution? A Critical Reading of Iris Young's Justice and the Politics of Difference", op. cit.

14. Soja Edward, "Heterotopologies: A Rememberance of Other Spaces in the Citadel-LA", in Postmodern Cities and Spaces, Watson Sophie, Gibson Katherine 
municative interaction of planners and their working environments ${ }^{15}$ and inspired by the Habermassian "communicative action" as the key to just and effective "deliberative" planning, at the expense of more structural, material or critical approaches ${ }^{16}$.

Fraser's critique opened the door for including of recognition of diversity in any consideration of a just city. Yet, and this is our main theoretical point, it appears as if recognition was adopted somewhat uncritically. For most Western scholars, recognition became a catch-all phrase for an act of including minority or weakened groups, allowing them a "voice" in the policy process. Recognition was to be accepted as the liberal or civil "right" to be heard, to be counted and represented. Beyond a general support of inclusion and participation, we wish to advance three main lines of critique to this approach. First, recognition as a "right" presupposes a benign state and political setting and an operating constitutional democracy, where rights can be secured through an independent judiciary. But rights alone are not enough, and should be supplemented by "capabilities" in order to progress towards a just city. Second, the emphasis and operationalization of liberal recognition is chiefly procedural; that is, focusing on participation and inclusion, but paying little attention to the material, economic and concrete power aspects of planning recognition. There have been numerous accounts of this "thin" type of recognition that often neglects and is therefore blind to material inequalities and oppressions ${ }^{17}$.

Third, and most importantly, liberal multicultural recognition tends to overlook the possibility that the marking of distinct groups may also harbor a range of negative consequences, beyond the neglect implied by the previous point. As shown by various studies dealing with minorities, recognition may lead to a process of "othering", and bear distinctively unjust material and political consequences. This negative potential often surfaces

(ed.), Oxford, Basil Blackwell, 1995, p. 13-34; Huxley Margo, Yiftachel Oren, "New Paradigm of Old Myopia? Unsettling the Communicative Turn in Planning Theory", in Journal of Planning Education and Research, vol. 19, 4, 2000, p. 333-342.

15. Forester John, Critical Theory, Public Policy and Planning Practice: Toward a Critical Pragmatism, Albany, State University of New York Press, 1993; Healey Patsy, Collaborative Planning: Shaping Places in Fragmented Societies, London, Macmillan, 1997.

16. Huxley Margo, Yiftachel Oren, "New Paradigm of Old Myopia? Unsettling the Communicative Turn in Planning Theory", op. cit.

17. Marcuse Peter, "Identity, Territoriality and Power", in Hagar: International Social Science Review, Vol 1, n 1, 2000, p. 128-143. 
in situations of ethnic, national, religious or racial conflict, where dominant groups are keen to reinforce the difference of weakened groups in order to perpetuate their disempowerment ${ }^{18}$.

\section{Urban Neo-Colonialism}

The main point behind the need to re-conceptualize recognition is the growing evidence of emerging urban neo-colonial relations, which put in motion a pervasive process we define as "creeping apartheid" and the widespread emergence of "gray" (informal) space as part of today's urbanity. Urban colonialism sees dominant elites, whose privilege draws upon their identity, class, and location utilize the contemporary city to advance three main dimensions of colonial relations. These dimensions are 1) Expansion (of material or power position) 2) Exploitation (of labor and/or resources), and 3) Segregation (construction of hierarchical and essentialized difference).

To be sure, these dimensions operate today in geopolitical conditions very different from classical European colonialism. Most strikingly, the global European conquest and settlement is now reversed, with a flow of disenfranchised, often status-less immigrants and indigenous peoples into the world's major cities. The economic power of the urban elites, and the weakness and deep difference of immigrants (whether from rural regions or overseas), create patterns of ethno-class segregation and economic disparities which often resemble the traditional colonial city ${ }^{19}$. This urban order is most prevalent in liberalizing ethnocratic states, which structurally privilege particular identities, while marginalizing minorities through both identity and economic regimes ${ }^{20}$.

These colonial-type urban relations are linked to the condition we term "creeping apartheid" in which groups enjoy vastly differing packages of rights and capabilities under the same urban regime, drawing on their class, identity and place of residence. The order is "creeping" because it is

18. Howitt Richie, "Recognition, Respect and Reconciliation: Steps towards Decolonisation?”, in Australian Aboriginal Studies, vol. 16, n 2, 1998, p. 3-16.

19. Al-SAYYAd Nezar, "Culture, Identity and Urbanism in a Changing World: a Historical Perspective on Colonialism, Nationalism and Globalization", in Preparing for the Urban Future: Global Pressures and Local Forces, Cohen Michael, Ruble Blair, Tulchin Joseph, Garland Allison (ed.), Baltimore, Woodrow Wilson Center Press, 1996, p. 106-133.

20. Roy Ananya, "Urban Informality: Toward an Epistemology of Planning", in Journal of the American Planning Association, vol. 71, n 2, 2005, p. 147-158. 
never declared, and is only partially institutionalized. Profound discrimination and inequality are based on both de-jure and de-facto mechanisms, which are commonly identified as "temporary." One of the most conspicuous "temporary" phenomena is the emergence of "gray" spaces, composed of informal, often illegal, development and populations ${ }^{21}$. Most typically, indigenous and immigrant minorities, squeezed between the various state and identity regulatory mechanisms, occupy and develop these gray spaces into a major component of today's metropolis, thereby augmenting the entrenchment of "creeping apartheid ${ }^{22 \text { ". }}$ Hence, despite its putative "temporariness", this exploitive and uneven urban order has been intensifying for decades, and the population of disenfranchised urban residents and workers has grown significantly, often into the millions ${ }^{23}$.

A variety of urban colonial relations are recorded in the non-Western cities $^{24}$ and mainly in cities of the first world that are focal points of mass immigration and economic growth ${ }^{25}$. Most of these studies find that identity and class inequalities are frequently connected, and that consequently, recognition and distribution intertwine in claims of social and spatial justice. Yet, identity and class also present different bases for human organization, which may undermine one another in the process of political mobilization yet not reducible to one another ${ }^{26}$.

Given the above, we claim that the rubric of "identity", "diversity", "difference", and the catch-all "multiculturalism" are often too vague and at times confused in the current urban literature. We offer a conceptual way forward by sketching a continuum of recognition types, with three main "ideal types" - affirmative, indifferent and hostile. These can assist in a more systematic analysis of the interaction between policy and identity.

\section{Ibid.}

22. Yiftachel Oren, Yасові Haim, "Control, Resistance and Informality: Jews and Bedouin-Arabs in the Beer-Sheva Region", in Urban Informality in the Era of Globalization: A Transnational Perspective, Al-SAYyad Nezar, Roy Ananya (ed.), London, Lexington Books, 2004, p. 118-136.

23. Roy Ananya, "Urban Informality: Toward an Epistemology of Planning", op. cit.

24. Robinson Jennifer, Ordinary Cities: between Globalization and Modernity, London, Routledge, 2006.

25. Marcuse Peter, "Identity, Territoriality and Power", op. cit.

26. Robinson Jennifer, Ordinary Cities: between Globalization and Modernity, op. cit.; Roy Ananya, "Urban Informality: Toward an Epistemology of Planning", op. cit. 
Affirmative recognition entails recognition of a group's identity with the associated cultural and material needs and aspirations; allocation of a fair share of power and resources. There are two main sub-types: proportional and privileged recognition, reflecting the group's power and importance in the policy arenas. Affirmative recognition often leads to the constitution of amicable multicultural relations and inter-group integration in the city, although it may cause some tension with marginalized minorities, who may object to the advantageous position of privileged groups.

Indifference means the passive existence of the distinct group in the policy process. It entails non-recognition of the group's specific identity and its associated needs and demands, with official acceptance of its members as formally equal members of the urban community. Indifference leads to implicit and covert types of group domination and discrimination, deriving from the inability of minorities to pinpoint their discrimination in the absence of clear categories about their existence as a group. This often prevents from setting legitimate collective goals. Sub-types include benign and marginalizing indifference, the first being typical of liberal regimes where the promise of individual mobility tempers group grievances, while the latter typifies illiberal conditions, where group assimilation is coerced without strong commitment to civil rights. The consequences depend on specific geopolitical and economic conditions, although in general, conflict levels are relatively low. The main focus of urban politics revolves around class and place, while identity politics is nudged to the periphery of the policy process.

Hostile recognition means the acknowledgement of group identity in policy-making, with a concurrent framing of its demands in a range of negative images to the dominant perception of a good city. Hostile recognition constructs the group in question as a nuisance or threat. Subtypes vary between implicit and explicit hostility, which in turn fluctuates according to the nature of the groups in question. The consequences of hostile recognition also vary according to the group type, size and setting, but they commonly cause the emergence of "gray" spaces of informal development, and generate a dynamic of antagonism and polarization. Levels of conflict are highest when national or religious minorities, with strong historical claims to the city, are subject to this type of policy.

Notably, the above categories, and those used later in the paper, provide an analytical grid which cannot capture the complexity of the policy-recognition nexus. We suggest here a conceptual map to help discern and organize the complex field, with full awareness that all categories are socially constructed and are never stable or complete. The application of each type 
of recognition depends on a range of historical and political factors negotiated and determined in a wide range of societal spheres and struggles. They also depend on the variegated nature of group identities, which vary in their depth and future goals, ranging between separation, autonomy, integration or assimilation.

Within this context, it is vital to remember that spatial policy is not a mere reflector of political forces imported from the "outside", but an important actor itself, which determines much of the way groups are treated in the public arena. While clearly set within an active political sphere, urban policy can assist in changing group position from marginalization and hostility towards recognition and equality, and vice versa, as depicted in Figure 1.

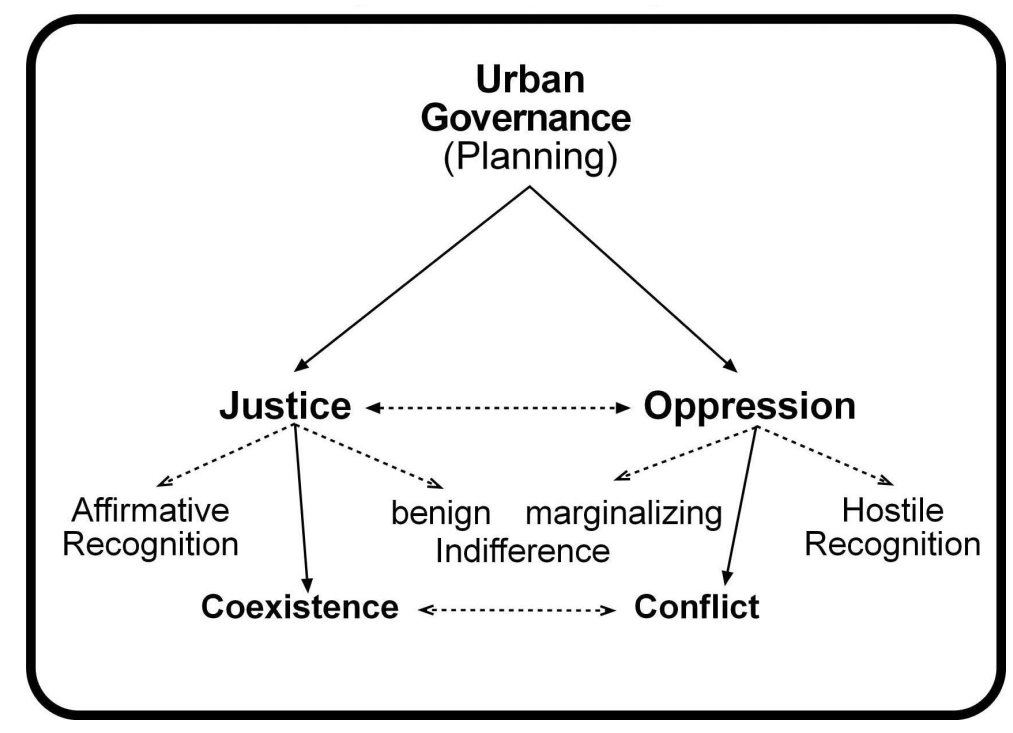

Fig. 1. Policy Justice, Recognition

With this conceptual framework in mind, let us proceed to the planning of the Beer Sheva region, and examine the ability of this framework to shed light on the connection between planning, justice and the city.

\section{Planning and Recognition(s) in Beer Sheva}

Beer Sheva is the main urban center of the Negev/Naqab region accommodates a population of 186,000 in the city, and some 560,000 in the 
metropolitan $\operatorname{area}^{27}$. The modern city was rebuilt by the Ottoman Empire as an urban service and control center for surrounding Bedouin tribes, and continued this function during the British Mandate period, remaining a small and predominantly Arab town.

During the Independent War in 1948, Beer Sheva was captured by Israel, which drove out about eighty percent of its Arab population to Gaza, Egypt, the West Bank and Jordan. The 11,000 who remained were awarded Israeli citizenship, but concentrated in a special military controlled zone known as "the siyag" ("the limit") as depicted in Figure 2.

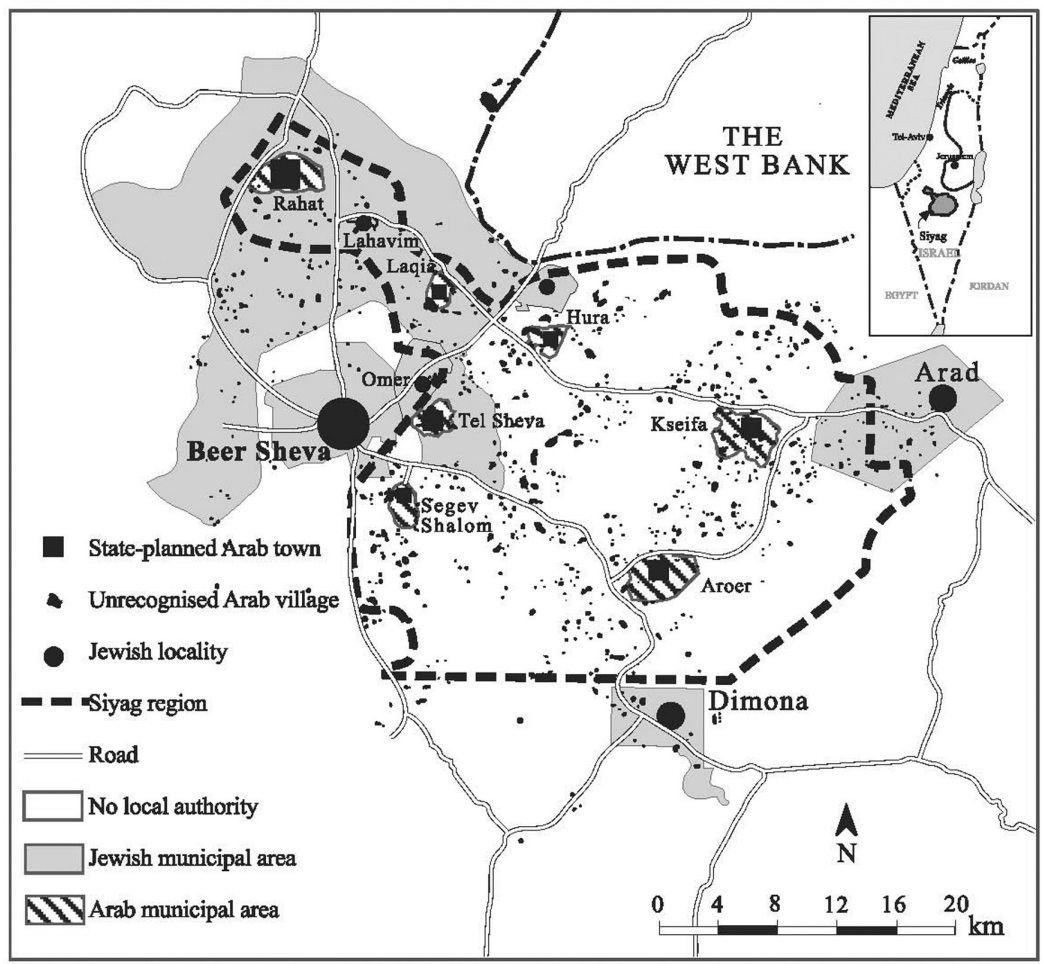

Fig. 2. La zone du Siyag

Source: Ministry of the Interior records. Aerial photograph analysis (1999)

The ensuing decades saw the first wave of concerted Israeli effort to Judaize the previously Arab Naqab, using a combination of deeply ethno-

27. BSCC (Beer Sheva City Council), Annual Report for 2006, Beer Sheva, City Council, 2007. 
cratic land, development, housing, and planning policies. Israel nationalized nearly all Bedouin land (leaving about fifteen percent of the region still under legal dispute), built eight new Jewish towns and some 105 rural Jewish settlements ${ }^{28}$. Masses of Jewish refugees and immigrants - mainly Mizrahim ("Eastern Jews") fleeing a hostile Arab world - were housed in large public housing estates, portrayed in the state planning discourses as the national frontier.

In a few short years, however, the frontier, including Beer Sheva, turned into a marginalized periphery, in what was termed the "frontiphery" pro$\operatorname{cess}^{29}$. Subsequently, the Beer Sheva region became characterized by social and economic under-development, mediocre levels of education and health, and a stigma deriving from its Mizrahi (Eastern) character ${ }^{30}$. This was most conspicuous in the "development towns" - Israel's version of new town policy aimed at housing immigrants and creating new urban communities.

Eight such towns were built in the Beer Sheva region during the implementation of one of Israel's most ambitious planning projects. The towns housed large numbers of Mizrahim during the 1950s and 1960s. Small groups of immigrants continued to arrive during the 1970s and 1980s, mainly from the Soviet Union, South and North America, and France, although they did not significantly alter the region's Mizrahi character.

In the 1990s a mass influx of Russian-speaking immigrants arrived from the former Soviet Union (hereafter Russians), and some groups of Ethiopians. The city of Beer Sheva, welcomed the new influx, which facilitated large scale development to accommodate the new housing demand, and a new planning and public discourse of a "globalizing city ${ }^{31}$ ". This demand

28. Meir Avinoam, "Negev Bedouins, Globalization and Planning and Metropolitan Beer Sheva", in Beer Sheva: Metropolis in the Making, Gradus Yehuda, MeirGlitzenstein Ester (ed.), Beer Sheva, Negev Center for Regional Development, Ben-Gurion University Press, 2008, p. 81-106 (Hebrew); Kedar Sandy, "On the Legal Geography of Ethnocratic Settler States: Notes Towards a Research Agenda”, op. cit.

29. Yiftachel Oren, Ethnocracy: Land and Identity Politics in Israel/Palestine, op. cit.

30. Cohen Eitan, Beer Sheva - the Fourth City, Jerusalem, Carmel, 2006.

31. Gradus Yehuda, "The Beer Sheva Metropolis: Polarized Multicultural Urban Space in the Era of Globalization", in Beer Sheva: Metropolis in the Making, op. cit.; Markovitz Fran, Urieli Natan, "Consumerism and Global/Local Identity in the Negev: the "BIG" Center and Beer Sheva's Old City", in Beer Sheva: Metropolis in the Making, op. cit., p. 212-228. 
used the vast reserves of low value state land, relaxed planning controls, and generous state incentives for large scale housing development ${ }^{32}$.

In 2007 the city population was composed of Mizrahim (41\%), Russians (31\%), Ashkenazim (8\%), Ethiopians (4\%) and Arabs (3\%), and six other small groups. In the wider metropolitan region, Mizrahim also constitute the largest group (29\%), while Russians (24\%) and BedouinArabs $(27 \%)$ also hold substantial proportions. The other groups are all smaller than four percent ${ }^{33}$.

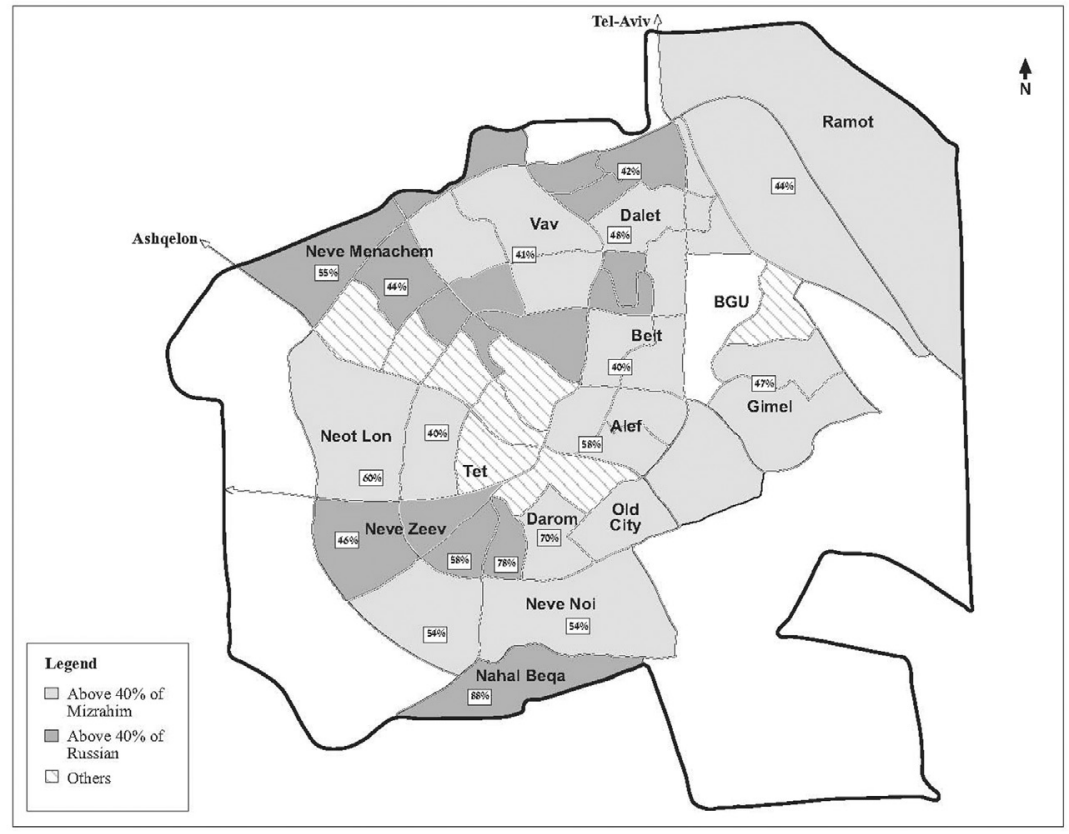

Fig. 3. Composition ethnique à Beer Sheva

Source: Central Bureau of Statistics (Israel). Demographic characteristics of populations in cities and statistical areas:

Population and households - select data. General Census 1999

32. Tzfadia Erez, Yacobi Haim, "Identity, Migration, and the City: Russian Immigrants in Contested Urban Space in Israel", in Urban Geography, vol. 28, n 5, 2007, p. 436-455.

33. NCRD (Negev Center for Regional Development), Distribution of Ethnicities in Beer Sheva city and Metropolis, selected data from Israel Bureau of Statistics 2006, Beer Sheva, Negev Center for Regional Development, 2007. 


\section{APPROACH}

For this project we have attempted to analyze the overall impact of spatial policies on the main cultural groups in the Beer Sheva metropolitan region. To this end, we analyzed the plans affecting city and region, which include: the 1952 national outline plan (TAMA 1); the 1978 southern district plan (Plan 4/1); the 1991 national plan (TAMA 31); the 1996 development plan for Beer Sheva (non-statutory); the 1998 metropolitan plan for Beer Sheva region (Plan 4-14); the 2005 national plan (TAMA 35); the 2007 metropolitan plan (Amendment Plan 4-14-23); and supporting urban housing, land and cultural policies of the Beer Sheva City Council.

These plans were developed by the ministries of Housing, Interior and Infrastructure, and the Israel Land Authority, and have been only partially successful and Beer Sheva remained a peripheral urban region in terms of its economic, political or cultural standing within Israeli/Palestinian space.

During this period of debate over the region, Israel implemented an urbanization planning strategy for the region's Bedouin Arabs. This has involved an attempt to concentrate the Bedouins into seven modern towns surrounding, but not part of, Jewish Beer Sheva (see Figure 2). This policy relocated about half the Arabs of the south (some 85,000 in 2007) and mainly those with no land claims, through the lure of modern infrastructure and prospects of modernization. However, despite some development, the towns became known for their marginality, unemployment, deprivation and crime ${ }^{34}$. The remaining Bedouins, estimated at 80-90,000, have steadfastly stayed on their disputed land in some 45 unrecognized (shanty) towns and villages (Figure 2). A protracted land dispute over this "gray" space has persisted for decades.

The combination of these plans and policies, and the accompanying discourses, regulations, and development initiatives are the subject of our analysis. We focus mainly on local and district plans, and pay special attention to the implications of these plans for the region's main ethnic communities - Russian, Mizrahi and Arab. We gain further insights by conducting a series of interviews with six key policy makers in the region, as well as 11 in-depth interviews with members of the communities in question.

34. Yiftachel Oren, "Territory as the Kernel of the Nation: Space, Time and Nationalism in Israel/Palestine", in Geopolitics, Vol. 7, 3, 2002, p. 215-248. 


\section{Planning and Affirmative Recognition: "RusSIAN" IMMIGRANTS}

Planning for immigrants from the former USSR in Beer Sheva has generally been marked by a benign attitude, premised on generous distribution and affirmative recognition, and couched within a long-term expectation of Russian integration into the Israeli-Jewish culture and society. The policy has been promoted jointly by an active state government, and by urban authorities interested in accommodating the immigrants ${ }^{35}$.

The main thrust of the urban policy towards the Russians, as reflected in National Plan $\mathrm{n}^{\circ} 31$ and the various Beer Sheva development plans, was the provision of rapid housing, first temporary and then permanent ${ }^{36}$. In parallel, the Israeli housing and planning systems thoroughly reorganized themselves and sped up the approval process, released previously protected agricultural land for urban development, and provided generous subsidies and incentives for both immigrants and developers. A level of $65 \%$ of home ownership was achieved in 2005, a mere 10-15 years after their mass arrival with meager financial or property resources ${ }^{37}$.

The influx of over 40,000 Russian immigrants to Beer Sheva during the 1990s, and a corresponding period of rapid economic growth, spawned large scale new housing and office construction ${ }^{38}$. Initially, the mass arrival caused economic and social concerns, because the population was relatively old, and relied heavily on the city's welfare services. However, within a decade, the economic benefits to the city outweighed the social costs, as the combination of social benefits and human skills propelled large sections within the Russian communities into the city's middle classes ${ }^{39}$.

City planning revisions created three large new neighborhoods on the outskirts of the city - Ramot, Nahal A'shan and Neve Ze'ev/Nahal Beka

35. Tzfadia Erez, Yacobi Haim, "Identity, Migration, and the City: Russian Immigrants in Contested Urban Space in Israel”, op. cit.

36. Gradus Yehuda, "The Beer Sheva Metropolis: Polarized Multicultural Urban Space in the Era of Globalization", op. cit.

37. Tzfadia Erez, “Trapped' Sense of Peripheral Place in Frontier Space”, in Constructing a Sense of Place: Architecture and the Zionist Discourse, YAсов Haim (ed.), Burlington, Ashgate, 2004, p. 119-135.

38. BSCC, Annual Report for 2006, op. cit.

39. Elias Nelly, Khvorostianov Natalia, "Not on Bread Alone: the Cultural Life of the Beer Sheva Russian Street", in Beer Sheva: Metropolis in the Making, op. cit, p. $45-68$. 
(Figure 3). The latter two are characterized by their high percentage of Russians, and their predominance in shaping local landscape and institutions.

With regard to culture, large parts of Beer Sheva's urban landscape have been "Russified", with signs, institutions and businesses catering to their growing demand for Russian products (especially food, drinks and sex ${ }^{40}$, supported, financially and planning by the Beer Sheva authorities.

This has also been reflected in Russian political organization, which formed several local parties, created conspicuous levels of collective Russian political representation in City Hall and appointing Russian professionals.

It is important to frame that Russians are still expected by the majority of Israelis to integrate and eventually assimilate into the mainstream Jewish community. Israel has not adopted an open multicultural approach, and denies the right for separate legislation or institutions for autonomous governance. Partial Russian autonomy is created "from below" by communities, markets, and local governments, and this cultural autonomy is thriving due to the population's overall development in accordance with the Zionist state and its Judaization project termed as "the ethnicization of Zionism ${ }^{41}$ ".

\section{Planning and (Marginalizing) Indifference: the Mizrahim}

The backbone of Beer Sheva's population is made up of the Mizrahim (Eastern Jews) who arrived en-mass to the region during the 1950s and 1960s. The treatment of these migrants by urban authorities can be termed, "marginalizing indifference."

From the outset, the Mizrahim were the "step child" of Zionism, mobilized to join the Jewish national movement after the horrific consequences of the Nazi holocaust of the 1940s. As Zionist-Palestinian tensions rose, Arab regimes and Islamic societies became increasingly hostile to Middle Eastern Jewry causing mass exodus during the late 1940s and early 1950s. Most of these Jews arrived in Israel and were housed by the state, first, in temporary camps, and later in mostly peripheral urban centers. Beer Sheva was one of the largest centers to accommodate Mizrahi immigration, with the city population rising six fold between 1950 and 1970.

40. Ibid.

41. Yiftachel Oren, Ethnocracy: Land and Identity Politics in Israel/Palestine, op. cit. 
But the type of recognition extended to the Mizrahim was condescending and marginalizing. Their inclusion into the Zionist project was premised on their Judaism, but at the same time on a denial of their Eastern and Arab cultural affiliation. The state attempted to re-build Jewish identity in the vision set by European secular elites. To that end, the masses of Mizrahim, who became a majority among Israel's Jews in the mid 1950s, had to be westernized, secularized and de-Arabized ${ }^{42}$.

In Beer Sheva, as noted, Mizrahim quickly made a decisive majority, accounting for over 70 percent of the population. However, the city leadership remained predominantly Ashkenazi (western Jewish). The Ashkenazi-Mizrahi tension marked much of the local political scene during the first three decades of the state, but no genuine Mizrahi leadership could prevail at this time.

Over the years, only one Mizrahi mayor was appointed during the 1970s and was considered as a soft "mizrahi ${ }^{43 \text { " }}$ with the influx of Russian immigrants, the Mizrahi "threat" was blunted. The two long-serving mayors who followed (one is incumbent), came from the traditional Ashkenazi elites, preventing city Mizrahi communities from receiving open, public recognition.

Urban planning initiatives for the Mizrahi immigrants involved dense, modernist, public housing developments, located in a dozen centrally planned "garden city" type neighborhoods across the city. During the last two decades, several new, low density, neighborhoods and three suburban "satellite" towns, have attracted most of Beer Sheva's (small) Ashkenazi population and those Mizrahim who moved into the middle classes. A degree of benign ethnic mixing began to occur in these localities, as it did in middle-class neighborhoods within the city limits. Large groups of Mizrahim still remain in the inner city stigmatized neighborhoods. Their employment was predominantly in labor-intensive industries and lowmedium-level public sector, as well as small traders and local businesses. This created a conspicuous overlap between their Mizrahi ethnicity and working and lower middle-class position.

The organization of Mizrahi parties was constantly undermined by the state and city leadership, and portrayed as "divisive" and harmful to the

42. Shenhav Yehuda., The Arab Jew: a Postcolonial Reading of Nationalism, Religion, and Ethnicity, Stanford, Stanford University Press, 2006.

43. Cohen Eitan, Beer Sheva - the Fourth City, op. cit. 
Israeli state project ${ }^{44}$. The local Mizrahi majority attempted to form a political block on several occasions during the 1960s, 1970s and 1980s, but was continuously thwarted by the concerted campaign to delegitimize Mizrahi "divisive" mobilization ${ }^{45}$.

The lack of political recognition was mirrored in the cultural sphere. Mizrahi culture was stigmatized in Israel and by implication in Beer Sheva during Israel's early decades. Most aspects of Mizrahi identity - family, dress, language, music, dwelling and even religion, were silenced or ridiculed in the public discourse, education system, cinema and popular culture. "Levantine" became synonymous with "primitive", leaving strong Mizrahi localities like Beer Sheva in deep identity crisis.

But this critical self-observation remains on the periphery of the public debate, and the marginalizing indifference among the elites by and large continued until the late 1980s. During the last two decades, some change can be traced, termed earlier "multiculturalism from below", The more liberal attitudes of recent years has yielded a measure of cultural recognition, revolving around Mizrahi holidays, music, food and cultural events, although these are more typically assigned to sub-groups (e.g. "Moroccan" or "Yemenite") than to a general Mizrahi identity. This liberalization serves to further highlight the lack of political organization, and Mizrahi narrative in the urban public sphere.

\section{Planning and Hostile Recognition: Bedouin Arabs}

One central aspect of spatial policy in the Beer Sheva metropolitan region has been the hostile recognition extended to the region's Bedouin Arab community. A bitter land conflict has developed with the state, which has continuously denied the Bedouins indigenous land rights, and as a result declared them "invaders" to their own historic localities. In an effort to force them to relocate, the state has refused to recognize their land claims, and has prevented the supply of most services, including roads, electricity, clinics and planning. House demolition campaigns are launched on a regular basis ${ }^{46}$.

44. Peled Yoav, Shas: the Challenge of Israeliness, Tel-Aviv, Yediot Ahronot, 2001 (Hebrew).

45. Cohen Eitan, Beer Sheva - the Fourth City, op. cit.

46. Yiftachel Oren, Ethnocracy: Land and Identity Politics in Israel/Palestine, op. cit.; Meir Avinoam, "Negev Bedouins, Globalization and Planning and Metropolitan Beer Sheva”, op. cit. 
Levels of poverty, child mortality, and crime are the worst in Israel/Palestine, and create a metropolitan geography of stark ethno-class contrast with the well-serviced adjacent Jewish localities. The Beer-Sheva metropolis has come to resemble many Third World cities that comprise a welldeveloped modern urban core, and a range of peripheral informal localities, suffering severe poverty and deprivation. It is here that the process of urban colonialism and "creeping apartheid" noted above, are most evident.

Arab campaigns against deprivation have highlighted both equality and identity, focusing on the right to reasonable material conditions, as well as cultural preservation ${ }^{47}$. In recent years, religion has played an increasing part in Arab urban campaigns, especially around education and places of worship.

Bedouin Arab representation in urban and regional planning affairs has ranged between non-existent and negligible. Despite being the indigenous inhabitants of the region, and constituting nearly a third of its current population, Bedouin presence in planning bodies has been meager and random. During the last decade, for example, only two Bedouins have sat on the district planning council (each in turn being one amongst 13 Jews in the council), and not even one Bedouin is represented on the Beer Sheva city council. Other planning bodies such as the Israel Land Authority, Ministry of Housing, Welfare and Education have occasionally included a single Arab member, but always in a position of distinct minority.

The combination of land, cultural, and material deprivations and a lack of representation, has bolstered antagonism towards the state and spurred the Bedouin Arabs to form their own institutions. The Regional Council for the Unrecognized Villages (RCUV) was formed in 1997 to combine the various localities surrounding Beer Sheva and present an alternative planning approach, based on full recognition of indigenous rights and equality. This form of "insurgent planning ${ }^{48 "}$ "rallied a group of notable NGO's to support the new (unrecognized) council, and caused some change in the public discourse. It is no longer possible to ignore the Bedouins as mere "invaders" or "outsiders" to the metropolitan region, and their demands are heard continuously in the media and in administrative and professional circles. 
The authorities have also been forced to recognize nine of the 45 unrecognized villages, although no infrastructure such as running water, roads or permanent schools, have been allocated to these localities as yet. Insurgent indigenous planning practices and the prevailing attitude of "hostile recognition" has clashed in recent years to cause spiraling polarization between Bedouins and authorities, with little progress towards resolving the conflict ${ }^{49}$. One such issue revolves around the renowned and architecturally significant Beer Sheva mosque, which was built by the Ottomans to serve the region's population. Despite constant Arab demands, the city refuses to open it for Muslim worship, with one powerful councilor of the ruling coalition, Eli Bokker claiming that "the region has dozens of mosques in Bedouin localities and towns, and Beer Sheva is now a Jewish city, with the right to protect this urban character ${ }^{50}$."

As a result, the Mosque has been lying idle for decades, and is now in an advanced state of architectural deterioration. Following a recent appeal by several NGO's, the Israeli high court ruled in favor of opening the mosque for "Arab cultural uses." Despite the latest ruling, the city is steadfast in its refusal, and has now condemned the building as too dangerous for human use.

Eli Bokker's statement is a reminder of the powerful narratives framing urban colonialism, and the resultant politics of denial, fear and hostile recognition as well as the process we termed "creeping apartheid".

\section{IMPACT AND REFLECTION}

The foregoing shows that, indeed, groups are recognized in very different ways by the urban policy process. One clear question that arises from this is what the long-term impact of such uneven recognition is, although its systematic examination must await a different context.

Yet, it is not difficult to intuitively associate negative types of recognition with socioeconomic marginalization and political weakness. This is supported by a cursory look at the socioeconomic standing of urban communities in the Beer Sheva region. We can take, for example, the "quality of life" index of localities prepared by the Israel Bureau of Statis-

49. Yiftachel Oren, Ethnocracy: Land and Identity Politics in Israel/Palestine, op. cit.

50. Sheva (local newspaper), May 9, 2005; a similar statement was made by Bokker in Kolbi (another local paper) in May 8, 1998. 
tics which is based on a combination of socioeconomic characteristics ${ }^{51}$. In the 2005 survey, the typical Russian neighborhood of Neve Ze'ev received a score of 12 (in a 1-20 range), while a decade earlier it received only a score of 8 . Another concentration of Russians, Nahal A'shan, received the score of 9 against 6 a decade earlier. In relative typical Mizrahi neighborhoods such as Schuna Gimmel, and Schuna Tet, the scores remained quite the same during the years: 8 in 2006 and 9 in 1995, and 13 in both years respectively. The Bedouin Arab localities surrounding Beer Sheva, Tel Sheva and Laqiyya scored 3 and 4, respectively in 2005, and 2 and 3 a decade earlier. These scores indicate the significant improvement of localities identified with Russians, as opposed to the stagnation characterizing localities with Mizrahi and Arab majorities. They also highlight notable differences with-in each cultural group, indicating that other forces are at work in the stratification process. Needless to say, the link between recognition and development requires a more in-depth investigation. This cursory look confirms however the importance of considering the specific type of recognition as a key element in theorizing justice and oppression in the city. Our understanding of spatial justice has indeed been complicated in recent years with the introduction of "recognition" as a major philosophical axis for justice claims, and by the mobilization of politics of identity. Recognition claims interact in complex ways with the well established call for fair distribution of material and political resources and fairness in decision making processes. The nature of this interaction is further complicated by our main argument in this paper, namely that recognition has to be studied critically, and that it may work for or against, the group in question.

Clearly, the questions raised in this paper present a major challenge to the justice literature, and need to be explored further - theoretically and empirically. The need for this investigation is reinforced in the rapidly changing urban world, where diversity, hierarchy, and identity politics are re-written within a globalizing economy, and within new regimes of uneven citizenship. We plan to continue the current exploration both comparatively, between various types of ethnically divided cities, and theoretically, engaging new debates over spatial justice which emerge from changing urban and political environments.

A promising way forward may be found in the further development of the Lefebvrian notion of "the right to the city" that lacks specific details on

51. CBS (Central Bureau of Statistics, Israel), Quality of Life Index 2005, Jerusalem, CBS, 2006. 
the precise nature and applicability of this right. This abstraction allows us to inject new meanings to the main features: centrality and difference of Lefèbvre's framework, reflecting a need to extend benign forms of recognition to all groups residing in the city. In such settings urban colonialism and "creeping apartheid" may be transformed into new forms of urban federalism based on equality, autonomy and redistribution.

Oren YifTachel, Ravit Goldhaber Departement of Geography and Environmental Development, Ben-Gurion University and Roy Nuriel Negev Center for Regional Development, Ben-Gurion University 

Space, Politics and (in)Justice

L'espace, le politique et l'injustice 


\section{Space, Politics and (in)Justice}

In the last decade or so, there has been a marked attempt in geography and urban studies, in the Anglophone academia at least, to think space politically and politics spatially. Notions and concepts that hardly escaped the confines of the fields of political science and theory have now entered, and started to orient to a certain extent, the research agendas of many scholars working in these fields. This, I believe, is good news for it renders the city and urban space as potentially political sites for the articulation and claiming of rights, and for fighting against various forms of injustice spatially produced or manifested.

A quick list, obviously not an exhaustive one, may be sketched with some of the issues that have recently been re-considered with a decidedly spatial focus. A first issue involves a growing concern with justice and the various forms of injustice inherent in the workings of the capitalist city ${ }^{1}$. Such a concern is closely related to a second issue; that is, considering emancipatory projects informed by a politics of space and the (re)construction of the city as a terrain of spatially informed politics². Formation of political

1. Harvey David, Justice, Nature and the Geography of Difference, Malden (MA) et Oxford (UK), Blackwell, 1996; The Urbanization of Injustice, Merrifield Andy et Swyngedouw Erik (ed.), New York, New York University Press, 1997; SojA Edward, Postmetropolis: Critical Studies of Cities and Regions, Oxford (UK) and Massachusetts (US), Blackwell, 2000; or earlier, Harvey David, Social Justice and the City, Baltimore, Johns Hopkins University Press, 1973.

2. Cresswell Tim, In Place/Out of Place: Geography, Ideology, and Transgression, Minneapolis, University of Minnesota Press, 1996; Keith Michael, "Street sensibility? Negotiating the political by articulating the spatial”, in The Urbanization of Injustice, op. cit., p. 137-160; Massey Doreen, For Space, London, Sage, 2005. 


\section{L'espace, le politique et l'injustice}

Au cours de la décennie qui vient de s'écouler, la géographie et les études urbaines, au moins dans le monde anglophone, se sont efforcées de penser l'espace en termes politiques et le politique en termes spatiaux. Des notions et des concepts qui restaient confinés dans les champs de la science politique et de la théorie politique se retrouvent maintenant dans les préoccupations de recherche des géographes et urbanistes, et les définissent jusqu'à un certain point. C'est une évolution dont on peut à mon sens se féliciter, car elle restitue à la ville et à l'espace urbain leur qualité de lieux du politique, où les droits peuvent être formulés, où les faire valoir, et d'où lutter contre différentes formes d'injustice produites ou manifestées spatialement.

Sans prétendre à l'exhaustivité, on peut citer quelques unes des questions qui ont récemment été repensées depuis une perspective ouvertement spatiale: c'est par exemple le souci de penser la justice et les différentes formes d'injustice inhérentes au fonctionnement de la ville capitaliste ${ }^{1}$. Ce souci n'est pas sans lien avec une autre question, celle des projets d'émancipation informés par une prise en compte de l'espace et la (re)construction de la ville comme terrain d'un politique structuré autour de l'espace ${ }^{2}$. La formation d'identités politiques et des réflexions sur la démocratie accompagnent

1. Harvey David, Justice, Nature and the Geography of Difference, Malden (MA) et Oxford (UK), Blackwell, 1996; The Urbanization of Injustice, Merrifield Andy et Swyngedouw Erik (dir.), New York, New York University Press, 1997; SojA Edward, Postmetropolis: Critical Studies of Cities and Regions, Oxford (UK) et Massachusetts (États-Unis), Blackwell, 2000; ou plus tôt encore, Harvey David, Social Justice and the City, Baltimore, Johns Hopkins University Press, 1973.

2. Cresswell Tim, In Place/Out of Place: Geography, Ideology, and Transgression, Minneapolis, University of Minnesota Press, 1996; Keiтh Michael, « Street sensibility? Negotiating the political by articulating the spatial ", in The Urbanization of Injustice, op. cit., p. 137-160; Massey Doreen, For Space, Londres, Sage, 2005. 
identities and deliberations on democracy accompany such projects ${ }^{3}$. A third issue that is easily discerned is the attempt to reconsider citizenship with a shift in focus from the state to the city, considering the city as a privileged site for the formation and practice of rights and political claims, and re-conceptualizing citizenship with an emphasis on its urban and spatial dimension ${ }^{4}$.

Besides more specific arguments, there is a strong argument that is being made, if not always explicitly, in these works as to the nature of the relation between space and politics: that space is not merely a "container" of politics, an immutable surface on which political processes unfold. Space, in other words, is more than a given and static container of politics; it is causal, transformative, and is itself always in the making. If this is so, however, space could be both a "good thing" for politics or a "bad thing"; that is, it could as much hinder political possibilities as it could engender them.

My conceptualization of the relationship between space and injustice follows from these strands of literature that, on the one hand, make space central to theoretical and empirical inquiry, and, on the other, refuse to assign space an a priori emancipatory quality, but rather recognize that most often than not, space seems to be a source of injustice or a means of control, mastery and domination (which, not despite but because of this very reason, can also become a significant tool of resistance). Spatiality of injustice is based on the premise that justice has a spatial dimension to it, and that one can observe and analyze various forms of injustice manifest in space. Injustice of spatiality shifts focus from spatial manifestations of injustice to structural dynamics that produce and reproduce injustice through space. The attempt, therefore, is not merely on the spatial manifestations of injustice, but equally importantly, on the processes that produce spatial

3. Place and the Politics of Identity, Keith Michael et Pile Steve (dir.), London, Routledge, 1993; WACQUANT Loïc, "America as social dystopia: The politics of urban disintegration, or the French uses of the "American Model", in Bourdieu Pierre et al., The Weight of the World: Social Suffering in Contemporary Society, Stanford, Stanford University Press, 1999, p. 130-39 [translated by Priscilla Parkhurst Ferguson, La Misère du monde, Paris, Éditions du Seuil, 1993]; Featherstone David, Resistance, Space and Political Identities, London, Wiley-Blackwell, 2008.

4. Brodie Janine, "Imagining democratic urban citizenship", in Democracy, Citizenship and the Global City, IsIn Engin (ed.), London, Routledge, 2000, p. 110-128; Holston James et Appadurai Arjun, "Cities and citizenship", in Public Culture, vol. 8, $n^{\circ}$ 2, 1996, p. 187-204; Isın Engin, Being Political: Genealogies of Citizenship, Minneapolis-London, University of Minnesota Press, 2002; Staeheli Lynn, "Globalization and the scales of citizenship", in Geography Research Forum, n 19, 1999, p. 60-77. 
de tels projets ${ }^{3}$. Un troisième point qui ressort clairement est l'effort pour repenser la citoyenneté non plus en référence à l'État, mais en référence à la ville, en considérant celle-ci comme un site privilégié pour la formation et la mise en œuvre de droits et revendications politiques, et en re-conceptualisant la notion de citoyenneté avec un accent nouveau mis sur sa dimension spatiale et proprement urbaine ${ }^{4}$.

Parmi les idées à retenir de ces travaux, l'une des plus saillantes concerne la nature de la relation entre l'espace et le politique: en substance, l'idée que l'espace n'est pas qu'un pur « contenant» du politique, une surface plane sur laquelle se déploieraient les processus politiques. L'espace n'est pas un donné, ou un support passif du politique; il joue un rôle causal, transformateur, et il est lui-même en devenir. En ce sens, l'espace est à la fois un élément positif ou un élément négatif du politique, puisqu'il peut limiter les champs du possible en politique autant qu'il peut les ouvrir.

Je construis ma conceptualisation de la relation entre espace et injustice à partir des thèses qui, d'une part, font de l'espace une entrée essentielle de leur réflexion, et d'autre part, refusent de prêter à l'espace une qualité émancipatrice a priori, et reconnaissent que le plus souvent, l'espace fonctionne comme source d'injustice et moyen de contrôle et de domination (pour cette raison même, il est possible que l'espace devienne un outil de résistance significatif). La notion de «spatialité de l'injustice » se fonde sur l'idée que la justice a une dimension spatiale, et qu'on peut observer et analyser différentes formes d'injustice qui se manifestent dans l'espace. L' « injustice de la spatialité », elle, renvoie non aux manifestations spatiales de l'injustice mais aux dynamiques structurelles qui produisent et reproduisent l'injustice par le biais de l'espace. Je m'intéresse donc, non seulement aux manifestations spatiales de l'injustice, mais à ce qui est également

3. Place and the Politics of Identity, Keith Michael et Pile Steve (dir.), Londres, Routledge, 1993; WACQUANT Loïc, "America as social dystopia: The politics of urban disintegration, or the French uses of the "American Model" ", in Bourdieu Pierre et al., The Weight of the World: Social Suffering in Contemporary Society, Stanford, Stanford University Press, 1999, p. 130-39 [traduit par Priscilla Parkhurst Ferguson La Misère du monde, Paris, Éditions du Seuil, 1993]; Featherstone David, Resistance, Space and Political Identities, Londres, Wiley-Blackwell, 2008.

4. Brodie Janine, "Imagining democratic urban citizenship ", in Democracy, Citizenship and the Global City, Isin Engin (dir.), Londres, Routledge, 2000, p. 110128; Holston James et Appadurai Arjun, "Cities and citizenship ", in Public Culture, vol. 8, nº 2, 1996, p. 187-204; Isın Engin, Being Political: Genealogies of Citizenship, Minneapolis-Londres, University of Minnesota Press, 2002; Staeneli Lynn, "Globalization and the scales of citizenship », in Geography Research Forum, $\mathrm{n}^{\circ} 19,1999$, p. 60-77. 
injustices ${ }^{5}$. In what follows, I will try to exemplify the interplay between the two - spatiality of injustice and injustice of spatiality - through a notion of "remainders", using the case of problematization of French banlieues as an example.

An instance to explain the notion of remainders may be provided by a brief recourse to arithmetic. When, for example, the number 100 is divided by 11 , the remainder is 1 . The notion of remainders implies a problematization of the status of the remainder: is 1 the remainder or the remaindered?

My definition of remainders is derived from Honig ${ }^{6}$. The implication is that the remainder 1 does not exist prior to and apart from the division process; it is remaindered by the very division operation. The notion, therefore, serves as an important reminder of remaindering processes, processes that produce the remainders themselves. Honig employs the notion to expose the remainders of political theory through its processes of closure. Any closure almost necessarily produces remainders. Therefore, it is possible, for example, to discern the remainders of a discourse, a theory, or a hegemonic project. The important point is to focus attention on process, rather than merely on form, and to see whether the discourse, theory, or hegemonic project in question relies on the remainders it produces as a source of legitimacy.

I use the notion of remainders both literally and figuratively to refer at once to the remaining and the remaindered. The former meaning may be exemplified by an OECD report on "integrating distressed urban areas". The housing market, the report states, through its dynamics of distribution and redistribution, is a major determinant of concentration. Since the post-war boom in social housing, conceived as an immediate response to housing shortage spawned by increasing population and/or immigration, private sector housing has developed to meet the demands of middle to low income

5. For more on this formulation, see Dikeç Mustafa, "Justice and the spatial imagination”, in Environment and Planning A, vol. 33(10), 2001, p. 1785-1805.

6. Honig Bonnie, Political Theory and the Displacement of Politics, Ithaca, Cornell University Press, 1993. 
important, les processus qui produisent les injustices spatiales ${ }^{5}$. Dans les paragraphes qui suivent, je me propose d'illustrer l'interaction entre les deux (la spatialité de l'injustice et l'injustice de la spatialité) au travers de la notion de « restes » (remainders), en utilisant le cas des banlieues françaises comme exemple.

Pour expliquer la notion de "restes ", on peut recourir brièvement à l'arithmétique. Par exemple, si l'on divise 100 par 11, le reste est 1. Il s'agit alors de problématiser le statut de ce « reste $^{6} »$.

Je m'appuie sur la définition de « reste» (remainder) par Honig ${ }^{7}$. Celle-ci suppose que le reste de 1 n'existe pas avant et en-dehors du processus de division: c'est l'opération qui en fait un reste. La notion rappelle donc utilement l'importance des processus qui produisent les restes. Pour Honig, en théorie politique, ce sont les processus de fermeture qui produisent les restes: on peut donc, par exemple, considérer comme "restes » les résultantes de tout processus de fermeture, de l'ordre du discours, de la théorie, ou du projet hégémonique. Ce qui est important, c'est de se concentrer sur le processus, et non simplement sur la forme, et de déterminer si le discours, la théorie ou le projet hégémonique en question instrumentalisent les restes qu'ils produisent comme source de légitimité.

J'utilise la notion de « restes » à la fois littéralement et métaphoriquement pour parler à la fois de " ceux qui restent » et de "ceux qui sont mis au rebut». On peut illustrer le premier sens à partir d'un rapport de l'OCDE sur «l'intégration des zones urbaines en difficulté ». D'après ce rapport, le marché du logement, par le biais de dynamiques de distribution et redistribution, produit de la concentration. Le développement massif d'habitat social au lendemain de la Seconde Guerre Mondiale, en réponse à la pénurie de logement liée à l'accroissement démographique et à l'immigration, a été suivi de l'émergence d'un marché de logements privés destinés aux ménages à revenus faibles ou moyens, qui a conduit beaucoup de

5. Pour plus de détails voir Dıкeç Mustafa, «Justice and the spatial imagination ", in Environment and Planning A, vol. 33 (10), 2001, p. 1785-1805.

6. En anglais, « remainder » renvoie à cette notion arithmétique de « reste », mais on parle aussi de "remaindering" par exemple pour la liquidation d'un stock de livres invendus. On ne peut, en français, rendre ce jeu sur le terme [NDT].

7. Honig Bonnie, Political Theory and the Displacement of Politics, Ithaca, Cornell University Press, 1993. 
families, many of whom left their initial public housing. "Those remaining in social housing are in many cases, those who are also least able to compete in the modern labour market and, hence, the most likely to be unemployed $^{7 ”}$. This translates into decreased tax returns and investment, and a process of deprivation - first in the physical environment - takes place:

When local actors - notably home-owners, businessmen, potential entrepreneurs, insurers, bankers, and local civil servants - perceive that such a process is taking place, they react to protect investments and minimize risk, and many choose to relocate ${ }^{8}$.

And this process eventually leads to a "vicious cycle":

First $[\ldots]$ once problems start to accumulate the better off residents begin to leave. The poorest, who have no choice, remain [...] Second, the worsening situation in the area, particularly as regards security, discourages business even more than before [...] Thirdly, resignation and underachievement tend to take root in the schools. Low educational performance tends to become normal and without the presence of an escape route through education, the spatial "poverty trap" then passes from one generation to the next ${ }^{9}$.

What is missing are the remainders themselves, those "who have no choice" but remaining; they are not even counted as "local actors". These quotes are used to clarify the literal use of the notion of remainders: those who remain "trapped in space ${ }^{10 "}$, or "chained to a place ${ }^{11 "}$ ", which can be seen as an instance of spatiality of injustice.

Figuratively, on the other hand, remainders refer to those that are left out whenever an attempt is made to systematically organize the world conceptually, categorically, linguistically, politically, culturally, socially, morally, and spatially.

7. OECD, Integrating Distressed Urban Areas, Paris, OCDE, 1998, p. 49; emphasis added.

8. Ibid., p. 51.

9. Ibid., p. 58; emphasis added.

10. Harvey David, The Urban Experience, Baltimore, Johns Hopkins University Press, 1989.

11. Bourdieu Pierre, "Site effects", in Bourdieu Pierre et al., The Weight of the World: Social Suffering in Contemporary Society, op. cit., p. 123-129. 
ces derniers à quitter leur logement social. «Ceux qui restent dans les logements sociaux sont, dans la plupart des cas, ceux qui sont les moins compétitifs sur les marchés du travail, et de ce fait, ceux qui ont les plus grandes chances de subir le chômage ${ }^{8} »$. Ceci conduit à un déclin des prélèvements fiscaux, donc des investissements, et une spirale de paupérisation, ressentie d'abord dans l'environnement matériel, s'enclenche:

Lorsque les acteurs locaux (notamment les propriétaires, les chefs d'entreprises, les entrepreneurs potentiels, les assureurs, les banquiers et les fonctionnaires locaux) perçoivent ce processus, ils réagissent de façon à protéger leurs investissements et minimiser leur prise de risque, et beaucoup choisissent de partir'.

Ce processus mène finalement à un « cercle vicieux » :

Premièrement $[\ldots]$ une fois que les problèmes commencent à s'accumuler les résidants les plus aisés commencent à partir. Les plus pauvres, qui n'ont pas le choix, restent [...]. Deuxièmement, la situation qui se dégrade dans le quartier, particulièrement en termes de sécurité, décourage les entreprises plus encore qu'avant [...]. Troisièmement, la résignation et l'échec tendent à s'enraciner dans les écoles. L'échec scolaire tend à devenir la norme et sans échappatoire via l'éducation, le "piège de la pauvreté » dans l'espace se transmet alors d'une génération à la suivante ${ }^{10}$.

Les grands absents sont les « restes » eux-mêmes, ceux qui n'ont d'autre choix que de rester: ils ne figurent même pas parmi les " acteurs locaux». Ces citations avaient pour but d'illustrer la notion littérale de « restes »: ceux qui sont "pris au piège de l'espace ${ }^{11}$ ", ou " enchaînés à un lieu ${ }^{12}$ ", dont le devenir illustre bien la spatialité de l'injustice.

D’un autre côté, au sens métaphorique, le terme de " restes » peut s'appliquer à tous ceux qui ne sont pas inclus dans une tentative systématique d'organisation du réel en termes conceptuels, catégoriques, linguistiques, politiques, culturels, sociaux, moraux, ou spatiaux.

8. OCDE, Integrating Distressed Urban Areas, Paris, OCDE, 1998; les italiques sont de l'auteur.

9. Ibid., p. 51.

10. Ibid., p. 58.

11. Harvey David, The Urban Experience, Baltimore, Johns Hopkins University Press, 1989.

12. Bourdieu Pierre, "Site effects", in Bourdieu Pierre et al., The Weight of the World: Social Suffering in Contemporary Society, op. cit., p. 123-129. 
The French case provides a typical example that brings together these two meanings. On the one hand, one finds certain groups of the population living in dilapidated peripheral areas of cities. On the other, these areas, under the rubric of "the banlieue", are being used to designate the problems of the society as places of "lack" (lack of order, lack of respect for the law, lack of urbanity, etc.), or "surplus" (too many immigrants, too much crime, etc.), reifying its fears. Inhabitants of such places not only remain spatially in these highly stigmatized areas, but are also remaindered socially and politically, as groups to be governed from above, to be "integrated", "included", rejected, or contained. They are too different, too poor, too violent, not integrated enough, not "French" enough, not urban enough. They are the remainders of urbanity.

How, then, is this remaindering done? Journalists, media intellectuals, "specialists", and policy makers and politicians have all played their part. A media review by Collovald, for example, demonstrates how this discursive construction of banlieues has made it possible to address the "immigration problem" (and immigrants as problem) in other, "more abstract and less directly political" terms, which was not the case when debates around immigration had started in the early 1980s. This is not an innocent modification, but one with significant political consequences, for "[i]n modifying the identification of the problem, it changes its meaning and signification $^{12}$ ". Since the 1990s in particular, "the banlieue", owing to such discursive constructions, has served as an appealing spatial and politically less charged metaphor to talk about such politically sensitive issues as immigration, and to frame problems in a way that drove certain issues away from perspective (e.g., structural dynamics, persistent inequalities, racism and discrimination, etc.) while introducing others (e.g., violence, crime, insecurity, etc.).

As I have tried to show elsewhere ${ }^{13}$, state policies - in particular, urban policy - have been very effective in the constitution of banlieues as remainders as they institutionalized many of the journalistic categories used to

12. Collovald Annie, "Violence et délinquance dans la presse. Politisation d'un malaise social et technicisation de son traitement", in Prévention et sécurité. Vers un nouvel ordre social ?, Bailleau Francis et Gorgeon Catherine (dir.), Saint-Denis La Plaine, DIV, 2000, p. 39-53, p. 39.

13. Dikeç Mustapha, Badlands of the Republic: Space, Politics and Urban Policy, Oxford, Blackwell, 2007. 
Le cas français constitue un très bon exemple de la conjugaison de ces deux acceptions. D'une part, on trouve certains groupes de la population qui vivent dans des quartiers dégradés des périphéries urbaines. D’autre part, ces quartiers, sous l'appellation générale de "banlieue », sont utilisés pour évoquer les problèmes de la société comme ressortissant de ces lieux de "manque " (manque d'ordre, manque de respect pour la loi, manque d'urbanité, etc.) ou de "surplus » (trop d'immigrés, trop de criminalité, etc.), comme outil de réification des peurs. Les habitants de tels lieux ne « restent » pas seulement spatialement dans ces quartiers stigmatisés, ils sont aussi socialement et politiquement déconsidérés (remaindered), comme groupes à gouverner d'en haut, à "intégrer ", à « inclure ", rejeter, ou contenir. Ils sont trop différents, trop pauvres, trop violents, pas assez intégrés, pas assez «français », pas assez urbains. Ils sont mis au pilon de l'urbanité (remainders of urbanity).

Comment fonctionne cette mise au pilon? Les journalistes, intellectuels médiatiques, les «spécialistes » et les politiques y jouent tous un rôle. Collovald, par exemple, s'appuie sur une étude des médias pour montrer comment la construction discursive des banlieues a permis de traiter «le problème de l'immigration" (et les immigrants comme "problème») dans des termes "plus abstraits et moins directement politiques » qu'il n'était possible de le faire lorsque le débat public autour de ces questions a commencé au début des années 1980. La modification n’a rien d'anodin, puisqu' « en modifiant l'identification du problème, on en change le sens et la signification ${ }^{13} »$. Depuis les années 1990, particulièrement, cette construction discursive de la «banlieue » a permis d'en faire une métaphore spatiale et de facto moins chargée de connotations politiques pour parler de thèmes sensibles comme l'immigration, et recadre les problèmes de façon à occulter certains aspects (les dynamiques structurelles, la persistence des inégalités, le racisme et les discriminations, etc.) et à en mettre d'autres en avant (par exemple la violence, la délinquance, l'insécurité, etc.).

Comme j'ai eu l'occasion de le montrer ailleurs ${ }^{14}$, les politiques de l'État, et en particulier la Politique de la Ville, ont été des plus efficaces pour constituer les banlieues comme "restes", dans la mesure où ce sont elles qui ont institutionnalisé beaucoup des catégories journalistiques utilisées

13. Collovald Annie, «Violence et délinquance dans la presse. Politisation d'un malaise social et technicisation de son traitement ", in Prévention et sécurité. Vers un nouvel ordre social?, Bailleau Francis et Gorgeon Catherine (dir.), Saint-Denis La Plaine, DIV, 2000, p. 39-53 (p. 39).

14. Dikeç Mustafa, Badlands of the Republic: Space, Politics and Urban Policy, Oxford, Blackwell, 2007. 
frame the banlieues. This constitution has not only externalized the remainders from the very remaindering processes, but also produced a hegemonic discourse on the banlieues. While the spatial designation of distressed areas is not inherently bad, and does not automatically produce remainders, the spaces designated by state policies have been subject to different discursive articulations over the years. Despite the republican anxiety over division and disunity, French urban policy operated with a divisive spatiality, eventually consolidating a rather rigid geography of "threat". The challenge, it seems to me, is to avoid the hegemony of this spatial order, and to conceive this state-led organization of space as part of the production of space rather than a "naturally given" organization.

\section{III}

My reading of French urban policy and other state policies addressing the banlieues suggests that policy making has had a role to play in this "naturalization"; first, through its particular spatial conceptualization, and second, through the discursive re-articulations of its spaces of intervention. Spatial delimitation and designation have been integral parts of French policy making. French urban policy is based on a definition of a "geography of priority neighbourhoods ${ }^{14}$ ", a geography constituted by the designated areas, which then becomes the basis of policy programmes and interventions. Based on how such areas have been constituted, Estèbe identifies two different "geographies": a "local" geography of priority neighbourhoods (in the 1980s) and a "relative" geography of priority neighbourhoods (starting from the 1990s). I follow his analysis, but also argue that it is possible to distinguish a third, "statist geography", from the mid-1990s onwards. These geographies also correspond to changing discursive terms associated with the banlieues and different forms of state intervention ${ }^{15}$.

14. Esтѐвe Philippe, "Instruments et fondements de la géographie prioritaire de la politique de la ville (1982-1996)", in Revue française des affaires sociales, $\mathrm{n}^{\circ} 3$, 2001, p. 25-38, p. 25.

15. This periodization is not meant to imply that each "geography" represented a rupture with the preceding period. Although there were noticeable changes in forms of state intervention, spatial conceptualization and discursive articulation of intervention areas in these periods, there were also many continuities among different policy programmes. 
au sujet des banlieues. Cette constitution n'a pas seulement dissocié les « restes » des processus qui les produisent, mais elle a aussi produit un discours hégémonique sur les banlieues. La désignation et la délimitation spatiale de secteurs en détresse sociale n'a rien d'intrinsèquement mauvais, et ne produit pas nécessairement des " restes », mais les espaces désignés dans le cadre des politiques de l'État ont subi des qualifications discursives qui ont varié au fil du temps. En dépit des phobies républicaines de la division et de la perte d'unité nationale, la Politique de la Ville a opéré des divisions spatiales et a conduit à terme à la consolidation d'une géographie assez rigide de la « menace ». Il me semble important de mettre en question l'hégémonie de cet ordre spatial, et de concevoir cette organisation de l'espace due en premier lieu à l'État comme partie intégrante d'une production de l'espace, plutôt que comme un donné « naturel ».

\section{III}

Ma lecture de la Politique de la Ville en France, ainsi que d'autres politiques s'appliquant aux banlieues, m'amène à penser que la formulation même des politiques a joué un rôle dans cette "naturalisation ", tout d'abord, par le biais de sa conceptualisation spatiale spécifique, et aussi par sa façon d'articuler discursivement ses espaces d'intervention. La délimitation spatiale et la désignation font partie intégrante de la mise en place des politiques. La Politique de la Ville se fonde sur la définition d'une " géographie des quartiers prioritaires ${ }^{15}$ », une géographie des espaces concernés, qui devient la base des programmes et interventions. Selon le mode de constitution des territoires de l'action publique, Estèbe identifie deux « géographies » différentes: une géographie « locale » des quartiers prioritaires (dans les années 1980), et une géographie « relative » (à compter des années 1990). Je reprends sa distinction, mais je distingue également une troisième géographie, que je qualifierais d' « étatique », à compter du milieu des années 1990. Ces géographies correspondent à l'association de termes différents à la banlieue, et à des formes différentes d'intervention de l'État ${ }^{16}$.

15. Estèвe Philippe, «Instruments et fondements de la géographie prioritaire de la politique de la ville (1982-1996) ", in Revue française des affaires sociales, $\mathrm{n}^{\circ} 3$, 2001, p. 25-38 (p. 25).

16. Cette périodisation n'implique pas que chaque "géographie» ait constitué une rupture par rapport à la précédente. Bien qu'on note des changements significatifs dans les formes d'intervention de l'État, la conceptualisation spatiale et l'articulation discursive des secteurs d'intervention entre ces périodes, les continuités dans les programmes sont également nombreuses. 
In the first period (roughly 1981-1989), policy makers tried to address perceived problems in certain social housing neighbourhoods located mostly in the banlieues. The situation in such neighbourhoods were seen as negative consequences of the economic crisis settling in, and they were referred to as working-class (or popular) neighbourhoods, which were the ones most hard hit by the loss of industrial and manufacturing jobs. Such was the spatial order that was starting to settle down: these "points in space" were characterized by a concentration of problems, and policy measures would spatially target such areas. They were not seen as separate from the urban areas that contained them. The borders that separated the banlieue from the city were situated in a particular geography and history; they were seen neither as naturally given nor immutable. The selection process was very much linked to local knowledge and specificities, and the role of inhabitants in the appropriation of their lived spaces was emphasized in the founding documents of urban policy.

Major institutional restructurings in 1989 and 1990 brought about new measures. With the initiation of the City Contracts program, the local geography turned into a relative (or contractual) geography, defined through negotiations between local and central actors. The institutionalization of urban policy made the question of social housing neighbourhoods and banlieues a national issue of political eminence. It also corresponded with the constitution of its problem, defined in spatial terms as "exclusion". But the specific context, both national and international, in which urban policy was institutionalized led to different discursive articulations of its spaces of intervention, diverging from the ways in which social housing neighbourhoods were seen by the earlier generation of policy makers. Marked by the unprecedented scale of riots in Vaulx-en-Velin, one of urban policy's neighbourhoods, the Islamic headscarf and Salman Rushdie affairs, Intifada and the forthcoming Gulf War, this context led to the articulation of the question of banlieues with immigration and Islam. It was in this context that a special section called "Cities and banlieues" was created at the French Intelligence Service.

In the contractual geography of urban policy, the neighbourhoods were seen as "neighbourhoods at risk". However during the 1990s, they have increasingly become associated with insecurity. They were no longer "at risk"; they were the very risk, the threat, that had to be confronted by the "re-foundation of the republican pact" and more security measures. This 
Au cours de la première période (grosso modo 1981-1989), les initiateurs de la politique ont cherché à remédier à des problèmes perçus dans certains quartiers d'habitat social situés surtout dans les banlieues. On voyait alors la situation de ces quartiers comme résultant des effets négatifs de la crise économique, et on en parlait comme de quartiers populaires (ou ouvriers), naturellement les plus touchés par la disparition d'emplois industriels et manufacturiers. Tel était l'ordre spatial qu'on commençait à établir: ces " points dans l'espace » étaient caractérisés par une concentration de problèmes, et les mesures politiques devaient spatialement viser ces secteurs. On ne les concevait pas comme distincts des aires urbaines où ils s'inscrivaient. Les limites séparant banlieue et ville relevaient d'une géographie historique particulière, on ne les voyait ni comme un donné naturel, ni comme immuables. Le processus de sélection s'appuyait très fortement sur une connaissance locale des spécificités des quartiers, et le rôle des habitants, vus comme devant se re-saisir de leurs espaces vécus, était souligné dans les documents fondateurs de la Politique de la Ville.

Des restructurations institutionnelles majeures intervenues en 1989 et 1990 amenèrent de nouvelles mesures. Avec la mise en place des « contrats de ville ", la géographie locale se transformait en une géographie relative (ou contractuelle), définie dans le cadre de négociations entre des acteurs locaux et le pouvoir central. L'institutionnalisation de la Politique de la Ville fit des quartiers d'habitat social et des banlieues une question d'ampleur nationale politiquement sensible. Cette tendance coïncida avec la redéfinition du problème en termes spatiaux comme " exclusion ». Mais les circonstances spécifiques, à la fois au niveau national et au niveau international, dans lesquelles la Politique de la Ville fut instituée, a conduit à des articulations discursives de ses espaces d'intervention différant considérablement de la façon dont les quartiers d'habitat social étaient vus par la génération politique précédente. Face aux émeutes d'une ampleur sans précédent qui se produisirent à Vaulx-en-Velin, l'un des plus anciens quartiers Politique de la Ville, à l'affaire des «foulards islamiques", et dans le contexte international de l'affaire Salman Rushdie, de l'Intifada puis du début de la guerre du Golfe, la question des banlieues en vint à être associée à l'immigration et à l'islam. Ainsi, une section spéciale "Villes et banlieues » fut créée aux Renseignements Généraux.

Dans la géographie contractuelle de la Politique de la Ville, les quartiers étaient vus comme "quartiers en danger "; mais au fil des années 1990, ils furent de plus en plus associés à l'insécurité. Ils n'étaient plus « en danger »: ils étaient devenus le danger, la menace à laquelle devaient répondre la « refondation du pacte républicain» et d'autres mesures sécuritaires. Ce pas- 
shift from risk to threat in the mid-1990s, once again, reflected larger happenings around the world. Following the 1992 Los Angeles riots, "ghettos" and references to the perils of the so-called "Anglo-Saxon model" became integral parts of the urban policy discourse. Wacquant ${ }^{16}$ shows that the dystopian images of the American city have been very influential in shaping the discourse on banlieues in France, and in this sense, it is emblematic that Mike Davis's City of Quartz was first translated into French in this period, in 1997 (followed by a reprint in 2000), seven years after its publication in English ${ }^{17}$. These dystopian images of the city were also accompanied by what Wacquant ${ }^{18}$ called "the punitive wind" blowing from the other side of the Atlantic, and the increased emphasis on security in this period also reflected "the intensification of social and spatial control" in the city with a security-obsessed urban discourse ${ }^{19}$, instilled with republican references.

Therefore, the third period, especially after the Pacte de relance of 1996, was marked by the transformation of the relative/contractual geography of the priority neighbourhoods of urban policy into a statist (étatique) geography. Local specificities disappeared, and the neighbourhoods of urban policy became hierarchized neighbourhoods of exclusion, some of which were "more excluded" than the others. This was also a shift from a relative geography of difficulties (now relativity exists merely among the excluded neighbourhoods themselves) to an absolute geography of threat, determined by centrally decided upon criteria, and rearticulated by a republican nationalist discourse. The neighbourhoods of urban policy were thus closed upon themselves, becoming "problems" as such. The inhabitants and local specificities, in the process, turned into internally homogeneous spatial categories, and the earlier ideas about appropriation of lived spaces by inhabitants themselves disappeared.

Such was the spatial order consolidated throughout the 1990s, which also informed the "new generation of city contracts" announced by the Jospin government. The priorities of urban policy, and with them the image of the banlieues and their inhabitants, were constantly being re-defined with

16. WACQuAnt Loïc, "America as social dystopia: The politics of urban disintegration, or the French uses of the 'American Model'", op. cit., p. 130-139.

17. Davis Mike, City of Quartz. Los Angeles, capitale du futur, Paris, La Découverte, 1997.

18. Wacquant Loïc, "Ce vent punitif qui vient d'Amérique”, in Le Monde diplomatique, April 1999, p. 1 and p. 24-25.

19. Soja Edward, Postmetropolis: Critical Studies of Cities and Regions, op. cit., p. 299. 
sage du danger à la menace, vers le milieu des années 1990, s’inscrivait aussi dans un contexte mondial: après les émeutes de Los Angeles en 1992, l'idée de "ghettos» et les références aux risques du soi-disant "modèle anglosaxon » devinrent des constantes du discours sur la Politique de la Ville. Wacquant a montré comment les images dystopiques de "la ville américaine » ont influencé le discours sur les banlieues en France ${ }^{17}$, et il est tout à fait révélateur que City of Quartz, le livre de Mike Davis, ait été traduit en français en 1997 (avec une ré-édition en 2000), sept ans après sa parution en anglais ${ }^{18}$. Ces images de la ville s'accompagnaient aussi de ce que Wacquant a appelé le «vent punitif » soufflant de l'autre côté de l'Atlantique ${ }^{19}$, et l'accent mis sur la sécurité au cours de cette période reflétait aussi «l'intensification du contrôle social et spatial» avec l'imposition d'un discours sécuritaire sur la ville imprégné de références républicaines ${ }^{20}$.

Dans une troisième période, surtout après le Pacte de relance de 1996, la géographie relative et contractuelle des quartiers prioritaires de la Politique de la Ville s'est transformée en géographie étatique. Les spécificités locales s'effaçaient, et les quartiers furent hiérarchisés en fonction de leur degré d'exclusion, certains étant "plus exclus» que d'autres. On passait également d'une géographie relative des difficultés (la relativité n'existant plus qu'entre les quartiers exclus eux-mêmes, plus en relation avec leurs aires urbaines environnantes) à une géographie absolue de la menace, définie en fonction de critères produits de manière centralisée, et intégrée dans un discours républicain nationaliste. Les quartiers Politique de la Ville étaient ainsi fermés sur eux-mêmes, constitués en tant que "problèmes ». Les habitants et les spécificités locales avaient été transformés en catégories spatiales homogènes, et les idées initiales sur l'appropriation des espaces vécus par les habitants disparaissaient.

C'est cet ordre spatial qui se consolida au fil des années 1990, y compris dans les « contrats de ville nouvelle génération » annoncés par le gouvernement Jospin. Les priorités de la Politique de la Ville, ainsi que l'image des banlieues et de leurs habitants, ne cessaient d'être redéfinies avec une insis-

17. WACQUANT Loïc, «America as social dystopia: The politics of urban disintegration, or the French uses of the "American Model" ", op. cit., p. 130-139.

18. Davis Mike, City of Quartz. Los Angeles, capitale du futur, Paris, La Découverte, 1997.

19. Wacquant Loïc, "Ce vent punitif qui vient d'Amérique ", Le Monde diplomatique, avril 1999, p. 1 et 24-5.

20. Soja Edward, Postmetropolis: Critical Studies of Cities and Regions, op. cit., p. 299. 
more emphasis on the republic, the issue of insecurity and the authority of the state. Despite the criticisms of the Sueur Report ${ }^{20}$ and those of the Cour des Comptes ${ }^{21}$, both of which maintained that "zoning" brought with it a string territorial stigmatization and that it was very difficult to get these neighbourhoods out of the "priority geography" of urban policy once they were included, urban policy's spatial focus has not changed. A comparison of the lists of the priority neighbourhoods of urban policy (16 neighbourhoods in 1982, 23 in 1983, 148 in 1984, 400 in 1989, 546 in the early 1990s, and around 1,200 in 751 ZUSs since 1996) shows that despite the increase in the number of neighbourhoods included, the list basically remains "unchanged"; that is, new neighbourhoods are constantly added to the list while the older ones remain. For example, the very 16 neighbourhoods that were selected in 1982 as "neighbourhoods in difficulty" when urban policy was experimentally initiated are still on the list. The same is true for about 500 neighbourhoods included since 1989 - they have practically all remained on the list since then.

Although the same spatial strategy (i.e., spatially targeting intervention areas) was in place since the early 1980s, it was in the third period that the exclusion of the neighbourhoods was absolutized. This points to a major trait of urban policy. The main issues that French urban policy is concerned with have not changed, but the way its intervention areas have been conceptualized and their representations have changed remarkably. Since the early 1980s, the shift of focus from "social development" to "security", from "prevention" to "repression", from "right to difference" to "the republican model of integration", and from "autogestion" to "the republican pact" did not ensue "naturally" from the changing nature of problems, but followed, to an important extent, from different discursive articulations of the spaces targeted by urban policy.

This brief account shows the naturalization of a certain spatial order (i.e. the geography of priority neighbourhoods of urban policy) and its different discursive articulations through state policies. The remaindering of the banlieues as a form of exteriority menacing the "values and principles of the republic" is not merely the product of the state's discursive practices, but also about the becoming hegemonic of a certain spatial order, a form of injustice of spatiality as the hegemonic spatial order has become a source of

20. Sueur J-P., Demain, la Ville, rapport présenté au ministre de l'emploi et de la solidarité, 2 vols., Paris, La Documentation française, 1998.

21. Cour des Comptes, La Politique de la ville. Rapport public particulier, Paris, Les éditions des Journaux Officiels, 2002. 
tance accrue sur la République, la question de l'insécurité et de l'autorité de l'État. Malgré les critiques formulées dans le rapport Sueur ${ }^{21}$ (1998) et par la Cour des Comptes 22 (2002), selon lesquelles le «zonage » conduisait à une stigmatisation territoriale en chaîne empêchant la sortie des quartiers de la "géographie prioritaire " une fois qu'ils y étaient inclus, la logique spatiale de la Politique de la Ville n'a pas changé. Une comparaison des listes des quartiers prioritaires montre bien que, alors même que leur nombre s'accroît (de 16 en 1982 à 148 en 1984, 400 en 1989, 546 au début des années 1990 et environ 1200 depuis 1996), la liste reste foncièrement inchangée: on ajoute de nouveaux quartiers, alors que les plus anciennement présents «restent». Ainsi, les 16 quartiers sélectionnés en 1982 comme " quartiers en difficulté » quand la politique fut lancée de manière expérimentale se trouvent toujours sur la liste. De même des près de 500 quartiers ajoutés depuis 1989, tous ou presque sont restés sur la liste depuis.

La même stratégie spatiale, consistant à définir des territoires d'intervention, a perduré depuis les années 1980, mais c'est au cours de la troisième période que l'exclusion des quartiers est absolutisée. Ceci renvoie à un trait essentiel de la Politique de la Ville. Les problèmes que prétend traiter la Politique de la Ville n'ont pas changé, mais la façon dont ses territoires d'intervention ont été conceptualisés, et les représentations dont elles sont l'objet, ont connu d'énormes changements. Depuis le début des années 1980, on est passé du " développement social » à la « sécurité », de la " prévention » à la « répression », du « droit à la différence » au « modèle républicain d'intégration », et de l' « autogestion » au " pacte républicain », non pas en réponse à un changement dans les problèmes, mais bien plutôt à la suite des changements dans les discours produits autour des espaces visés par la Politique de la Ville.

Cette brève évocation illustre une forme de naturalisation d'un ordre spatial (la géographie des quartiers prioritaires de la Politique de la Ville) et les différentes façons de l'articuler discursivement par le biais des politiques étatiques. La construction des banlieues comme "restes» (remainders), comme forme d'extériorité menaçant les «valeurs et principes de la République » ne sont pas de simples résultantes des pratiques discursives de l'État, mais aussi de l'hégémonie d'un ordre spatial, une forme d'injustice de la spatialité dans la mesure où cet ordre hégémonique est aussi source de

21. Sueur J-P., Demain, la Ville, rapport présenté au ministre de l'emploi et de la solidarité, 2 vols., Paris, La Documentation française, 1998.

22. Cour des Comptes, La Politique de la ville. Rapport public particulier, Paris, Les éditions des Journaux Officiels, 2002. 
stigma. Such a spatial order and its discursive register, to be sure, has been used by successive governments to legitimize increasingly repressive measures directed towards the banlieues. It has been, in other words, an integral part of the so-called "securitarian ideology", said to be characteristic of the last four governments. Or better yet, it has been the product of this ideology, which contributed to the remaindering of the banlieues in the established "police order".

\section{IV}

What is ultimately important for me is to dismiss the facile opposition between a plane of appearances and a plane of reality and to show $[\ldots]$ how it is that the "social" - a category supposedly intended to explain away and thereby refute the "ideological" - is in fact constituted by a series of discursive acts and reconfigurations of a perceptive field ${ }^{22}$.

What is an ideology without a space to which it refers, a space which it describes, whose vocabulary and links it makes use of, and whose code it embodies?... [W] hat we call ideology only achieves consistency by intervening in social space and in its production, and by thus taking on body therein. Ideology per se might well be said to consist primarily in a discourse upon social space ${ }^{23}$.

"The police", in its non-pejorative sense, is the name Rancière gives to orders of governance. It is based on a particular regime of representation, to which he refers to as "the partition of the sensible", defined as "that system of sensible evidences that discloses at once the existence of a common [i.e., the whole to be governed] and the partitions that define the respective places and parts in $\mathrm{it}^{24}$ ". The partition of the sensible, as a system of sensible evidences, arranges the perceptive givens of a situation - what is in or out, central or peripheral, audible or inaudible, visible or invisible. The police, then, is not self-evident or naturally given, but rather a product of a particular regime of representation, or what Rancière calls sensible evidences. It is exemplary in this sense that one of the first measures the then French Minister of the Interior Nicolas Sarkozy had proposed, when he first took office in 2002 with a stated aim to "restore the Republican order", was to

22. RANCIÈRE Jacques, "Dissenting words: A conversation with Jacques Rancière", in Diacritics, vol. 30, no 2, p. 113-126, p. 117.

23. Lefèbvre Henri, La Production de l'espace, Paris, Anthropos, $4^{\text {th }}$ edition, 2000 [1974], p. 55.

24. Rancière Jacques, Le Partage du sensible: Esthétique et politique, Paris, La Fabrique, 2000, p. 12. 
stigmatisation. Cet ordre spatial et son registre discursif ont ainsi été utilisés par les gouvernements successifs pour légitimer des mesures de plus en plus répressives à l'encontre des banlieues. En d'autres termes, il fait partie intégrante de l'«idéologie sécuritaire » dont il a été montré qu'elle est caractéristique des quatre derniers gouvernements. Ou, mieux encore, c'est un produit de cette idéologie, qui a contribué à la mise au pilon (remaindering) des banlieues dans le cadre de l'ordre policier établi.

\section{IV}

Ce qui est important pour moi, finalement, c'est de mettre en cause l'opposition simpliste entre un niveau des apparences et un niveau de réalité et de montrer [...] comment le «social »- une catégorie censée expliquer et réfuter l'« idéologique » - est en fait constitué par une série d'actes discursifs et de reconfigurations d'un champ de perceptions ${ }^{23}$.

Qu'est-ce qu'une idéologie sans un espace auquel elle se réfere, qu'elle décrit, dont elle utilise le vocabulaire et les connexions, dont elle contient le code?... Plus généralement, ce qu’on nomme "idéologie » n'acquiert de consistance qu'en intervenant dans l'espace social, dans sa production, pour y prendre corps. En soi, ne consisterait-elle pas surtout en un discours sur cet espace ${ }^{24}$ ?

"La police», au sens non péjoratif du terme, c'est le nom que Rancière donne aux ordres de la gouvernance. Elle se fonde sur un régime particulier de représentation, auquel il se réfere avec l'expression « le partage du sensible », défini comme " ce système d'évidences sensibles qui donne à voir en même temps l'existence d'un commun et les découpages qui y définissent les places et les parts respectives ${ }^{25} »$. Le partage du sensible, comme système d'évidences sensibles, ordonne les donnés perceptibles d'une situation - ce qui est à l'intérieur ou à l'extérieur, central ou périphérique, audible ou inaudible, visible ou invisible. La police n'a rien d'évident ou de donné, c'est au contraire le produit d'un régime de représentation spécifique, ou ce que Rancière appelle des évidences sensibles. Par exemple, l'une des premières mesures prises par Nicolas Sarkozy lors de son entrée en fonctions comme ministre de l'Intérieur, en 2002, avec comme but explicite de "restaurer

23. RANCIÈRE Jacques, "Dissenting words: A conversation with Jacques Rancière ", in Diacritics, vol. 30, nº 2, p. 113-126, p. 117.

24. Lefèbvre Henri, La Production de l'espace, Paris, Anthropos, $4^{\mathrm{e}}$ edition, 2000 [1974], p. 55.

25. Rancière Jacques, Le Partage du sensible: Esthétique et politique, Paris, La Fabrique, 2000, p. 12. 
modify the periodicity of the publication of figures of delinquency, and to make them publicly available more frequently ${ }^{25}$.

Rancière's conceptualization of the police as consolidated through the putting in place of sensible evidences suggests a way of looking at state policies. State policies put in place certain sensible evidences (policy documents, spatial designations, mappings, categorisations, namings and statistics) that help to consolidate a particular spatial order and encourage a particular way to think about it. In the French case, the spatial order that state policies helped to consolidate with its designations of intervention areas (the banlieues) became officially so accepted that when the French Intelligence Service decided to engage with the question of banlieues, it was the list of urban policy neighbourhoods that they took as a starting point. When the Ministry of Justice engaged with the issue with a stated aim to restore the law, its measures aimed at the same neighbourhoods. Similarly, other repressive measures (like security contracts, Sarkozy's flash-ball guns, etc.) and growing anxieties about the "values of the republic" were all guided by the same spatial imaginary, which became the basis for the consolidation of what I call the "republican penal state" from the 1990s onwards ${ }^{26}$.

Arguably, the most perverse consequence of the consolidation of this spatial order - the police - has been the constitution of banlieues as spaces that somehow do not fit, excluded, dangerous, deviant - as, in other words, a form of exteriority that menaces the integrity of "the Republic". By confining the "other" into a geographical elsewhere, by closing the banlieue in itself, this constitution not only removed from perspective the structural dynamics of persistent inequalities - that is, shifted focus away from the remaindered to the remainder itself - but also reconfigured the "givens" of the situation by representing the banlieue in itself as a problem. This has, furthermore, made it possible to debilitate potential movements of justice rising from the banlieues; first, by legitimizing repressive measures and surveillance techniques, and second, by turning political claims into disturbances. Since the mid-1990s, no government has seen the recurrent banlieue

25. "Le ministre veut publier plus fréquemment les chiffres de la délinquance", in Le Monde, 31 May 2002.

26. Dikeç Mustafa, Badlands of the Republic: Space, op. cit. 
l'ordre républicain", fut la modification de la périodicité de publication des chiffres de la délinquance, pour les rendre publics plus fréquemment ${ }^{26}$.

En nous appuyant sur la façon dont Rancière conceptualise la police, en tant que consolidée par la mise en place d'évidences sensibles, nous pouvons interpréter les politiques de l'État. Celles-ci mettent en place un certain nombre d'évidences sensibles (des documents programmatiques, des désignations spatiales, de la cartographie, des catégorisations, des dénominations et des statistiques) qui aident à consolider un ordre spatial spécifique et encourage une façon particulière de le penser. En France, l'ordre spatial institué en partie par les politiques de l'État, avec la désignation d'aires (de territoires?) d'intervention (les banlieues) en vint à être tellement accepté officiellement que lorsque les RG furent chargés de traiter la question des banlieues, c'est la liste des quartiers de la Politique de la Ville qui a été prise comme point de départ. Quant le ministère de la Justice s'est préoccupé de la question, avec pour but affiché de "rétablir l'ordre légal », ses mesures ont porté sur les mêmes quartiers. De même d'autres mesures répressives (comme les contrats de sécurité, les flash-balls de Sarkozy, etc) et les anxiétés croissantes au sujet des "valeurs de la République » ont été conditionnées par le même imaginaire spatial, qui a servi de fondement à la consolidation de ce que j'appelle « l'État pénal républicain » à compter des années $1990^{27}$.

On peut penser que la conséquence la plus néfaste de la consolidation de cet ordre spatial - la police - a été la constitution des banlieues comme espaces qui, en quelque sorte, font pièce rapportée, sont exclus, dangereux, déviants - comme, pour le dire autrement, une forme d'extériorité qui menace l'intégrité de «la République ». En confinant l' «Autre» dans un ailleurs géographique, en fermant la banlieue sur elle-même, cette perspective dissimule les dynamiques structurelles qui font persister les inégalités (ou autrement dit, l'opération qui produit les " restes ») et reconfigure les données de la situation en représentant la banlieue elle-même comme problème. C'est ce tour de passe-passe qui permet, de plus, de discréditer les mouvements qui naissent en banlieue pour revendiquer plus de justice: d'abord, en légitimant les mesures répressives et les techniques de surveillance, et ensuite en faisant des revendications politiques des perturbations de l'ordre public. Depuis le milieu des années 1990, aucun gouvernement n'a vu dans les révoltes récurrentes qui se sont produites

26. "Le ministre veut publier plus fréquemment les chiffres de la délinquance ", in Le Monde, 31 mai 2002.

27. Dikeç Mustafa, Badlands of the Republic: Space, op. cit. 
revolts as anything more than pointless looting and burning, which was not the case in the 1980s and early 1990s.

To follow the remarks of Lefèbvre that open this section, ideology may be seen as a discursive reconfiguration of social space, which establishes the terms of a discourse with which problems are identified, solutions shaped, measures legitimized, and claims articulated. This social space, however, is not naturally given, although it may seem to be naturalized. The sheer contingency of the established order may be questioned by opening up new discursive spaces organized around different discursive terms, which could form the basis of new political formations that act on the police. It is in this sense that a notion of "spatial justice" can be mobilized as a critique of systematic exclusion, domination and oppression, which are reproduced, among other things, by the police order that has been consolidated.

Mustafa Dikeç Department of Geography Royal Holloway, University of London 
dans les banlieues plus que des pillages et incendies gratuits, alors que ce n’aurait pas été le cas dans les années 1980 et au début des années 1990.

Pour reprendre les idées de Lefèbvre sur lesquelles s'ouvre cette partie, l'idéologie peut être vue comme une reconfiguration discursive de l'espace social, qui établit les termes d'un discours avec lequel les problèmes sont identifiés, les solutions formulées, les mesures légitimées, et les revendications avancées. Cet espace social, pour naturalisé qu'il soit, n'est pas naturellement donné. La contingence de l'ordre établi peut être contestée par l'ouverture de nouveaux espaces discursifs organisés autour de termes différents, qui pourraient constituer la base de nouvelles formations politiques susceptibles d'agir sur la police. C'est en ce sens qu'on peut mobiliser la notion de " justice spatiale ", pour critiquer l'exclusion systématique, la domination et l'oppression, qui se reproduisent entre autres par le biais de l'ordre policier. 

SÉGRÉGATION SPATIALE, ÉQUITÉ TERRITORIALE ET ACCÈS AUX RESSOURCES URBAINES 



\section{Distance physique, proximité sociale et inégalités devant le chômage}

L ES CATÉGORIES POPULAIRES sont de loin les principales victimes du chômage. En 2010, en France, 19,6 \% des ouvriers non-qualifiés étaient au chômage contre $4 \%$ pour les cadres supérieurs. L'économie et la sociologie du travail ont apporté les explications majeures de cette inégalité devant le chômage. Mais, aux États-Unis notamment, l'économie et la sociologie de la ville ont également proposé des pistes pour expliquer ces différentiels. Deux facteurs proprement urbains seraient susceptibles d'alimenter le chômage, et plus encore celui des classes populaires.

Le premier facteur renvoie à une question de distance/dispersion. C'est l'hypothèse d'un "spatial mismatch »: la dissociation croissante entre lieux d'habitat et lieux d'emploi serait source d'une faible accessibilité à l'emploi pour les actifs les plus modestes et les moins bien reliés aux lieux d'emploi. Les distances internes de la ville dispersée pèseraient sur le devenir professionnel de ceux qui contribuent le moins à en imprimer les formes. L'autre ressort urbain évoqué dans l'explication du chômage des catégories populaires est associé au contraire à une question de proximité/concentration et suggère l'existence d' « effets de quartier ». La concentration des ménages défavorisés dans les quartiers les plus dévalorisés de la ville serait génératrice d'un environnement où, dans la proximité de chacun, dominent pauvreté et détresse sociale. Vivre au quotidien dans de tels environnements aurait des conséquences négatives sur le destin social des résidents.

Ces analyses ont suscité des débats d'autant plus vifs, outre-atlantique, que leurs résultats alimentaient nécessairement une discussion sur l'opportunité d'une action publique contre la ségrégation. Le bilan est controversé $^{1}$, mais plusieurs études ont fourni des résultats corroborant

1. Voir Gordon Peter, Kumar Ajay et Richardson Harry, "The spatial mismatch hypothesis: some new evidence », in Urban Studies, ${ }^{\circ} 26,1989$, p. 315-326; KaIN John, "The Spatial Mismatch Hypothesis: Three Decades Later », in Housing Policy Debate, $\mathrm{n}^{\circ} 3$ (2), 1992, p. 371-460; Ihlandfeld Keith et SJoquist David, 
l'hypothèse de variables spatiales "agissantes ». Dans le cas français, les recherches empiriques sont beaucoup plus rares ${ }^{2}$.

La présente contribution souhaite enrichir le corpus empirique existant en explorant le rôle de l'espace - et de la difficulté à s'en affranchir - dans l'exposition au chômage des actifs les plus modestes, dans le cas de la région parisienne, grande aire urbaine de onze millions d'habitants. On exposera (i) les fondements théoriques des hypothèses sur les effets de l'espace, (ii) les partis pris méthodologiques retenus dans la présente recherche et le corpus des données mobilisées ${ }^{3}$, puis (iii) les principaux résultats, qui feront l'objet (iv) d'une discussion finale.

\section{THÉORIES SUR LE RÔLE DE L’ACCESSIBILITÉ ET DE L'EXPOSITION À UN ENVIRONNEMENT DÉFAVORISÉ DANS LE RISQUE DE CHÔMAGE}

Pour certains auteurs, la configuration actuelle de la ville fournit une part d'explication aux plus grandes difficultés d'emploi rencontrées par les classes populaires. Toutes choses égales par ailleurs, certains quartiers de la ville offriraient une faible accessibilité à l'emploi ou exposeraient leurs habitants à un environnement marqué par le chômage et la pauvreté, entraînant un sur-risque de chômage, et les classes populaires seraient sur-représentées dans de tels quartiers. On expose ici les fondements de cette analyse.

\footnotetext{
" Job accessibility and racial differences in youth employment rates", in American Economic Review, n 80, 1998, p. 267-276; MARPSAT Maryse, "La modélisation des effets de quartier aux États-Unis. Une revue des travaux récents", in Population, no 54 (2), 1999, p. 303-330; BaCQue Marie-Hélène et Fol Sylvie, «Effets de quartier: enjeux scientifiques et politiques de l'importation d'une controverse ", in Le Quartier. Enjeux scientifiques, actions politiques et pratiques sociales, AuthiER JeanYves et al. (dir.), Paris, La Découverte, 2007, p. 181-193.
}

2. Voir Marpsat Maryse et Laurent Raphaël, «Le chômage des jeunes est-il aggravé par l'appartenance à un quartier en difficulté? ", in En marge de la ville, au coeur de la société: ces quartiers dont on parle, collectif, Paris, L'Aube, 1997, p. 231251; Choffel Philippe et Delattre Éric, « Habiter un quartier défavorisé: quels effets sur la durée de chômage? ", in Premières Synthèses, nº 43.1, DARES, 2003; Gaschet Frédéric et Gaussier Nathalie, "Ségrégation urbaine et marchés du travail au sein de l'aire urbaine bordelaise: quelle portée pour l'hypothèse de mauvais appariement spatial?" " in Cahiers du GRES, n 14, 2003; GobILlon Laurent et Selod Harris, "Les déterminants spatiaux du chômage en Île-de-France ", in Ségrégation urbaine et intégration sociale, Fitoussi Jean-Paul et al, Paris, La Documentation Française, 2004, p. 171-187.

3. Nous remercions le Groupe Études et Stratégies des Transports de la Division des Infrastructures et des Transport (DIT) de la DREIF pour la mise à disposition de données nécessaires à la conduite de cette recherche. 


\section{Accessibilité à l'emploi et risque de chômage}

Les économistes de l'urbain considèrent que le marché du travail fonctionne d'autant mieux qu'il est grand. Offres et demandes d'emploi ont alors de meilleures probabilités de se rencontrer rapidement et de se satisfaire, limitant ainsi la durée des périodes de chômage . Pour un actif sédentaire (c'est-à-dire qui n'envisage pas de déménager) en recherche d'emploi, l'offre d'emploi n'est pas égale à la somme des emplois localisés dans la ville où il vit. Elle correspond aux seuls emplois qui lui semblent à sa portée depuis son domicile. Il s'ensuit que l'offre d'emploi effectivement disponible est une fonction de l'accessibilité. Meilleure est l'accessibilité à l'emploi, plus large est le marché de l'emploi «effectif» des demandeurs d'emploi ${ }^{5}$. A contrario, une mauvaise accessibilité réduit le volume de l'offre et risque alors d'allonger les périodes de chômage.

Deux grands facteurs déterminent le niveau d'accessibilité à l'emploi: (i) la distance qui sépare les emplois du lieu de résidence, et (ii) la capacité à s'affranchir de ces distances grâce à des déplacements rapides. Sur cette base, il fait peu de doute qu'aujourd'hui, les classes populaires disposent d'une moindre accessibilité à l'emploi dans les villes et ce pour deux raisons.

Premièrement, pour une part importante, la localisation résidentielle dépend de la capacité d'enchère des ménages. Or, ces capacités sont les plus modestes chez les catégories populaires, ce qui les contraint souvent aux secteurs excentrés de la ville, les moins chers parce que les moins proches des ressources et aménités urbaines ${ }^{6}$. D’un autre côté, les activités économiques recourant abondamment au travail peu qualifié recherchent moins la centralité si bien que l'emploi à destination des catégories populaires se localise plus souvent que les autres à la périphérie des agglomérations.

Dans le cas francilien, on vérifie bien que les résidences et les lieux d'emplois des ouvriers sont abondamment disséminés dans les zones périphériques peu denses: $48 \%$ des résidences et $43 \%$ des emplois sont situés en

4. Veltz Pierre, Des territoires pour apprendre et innover, Paris, L'Aube, 1994; JAYET Hubert, "Villes et marchés du travail ", in Ville et emploi. Le Territoire au cour des nouvelles formes du travail, PERrin Évelyne et Rousier Nicole (dir.), Paris, L'aube, 2000, p. 53-64.

5. Prud'homme Rémy et Lee Chang, «Size, Sprawl, Speed and the Efficiency of Cities », in Urban Studies, $n^{\circ} 36$ (11), 1999, p. 1849-58.

6. Initialement, dans la littérature américaine, c'est la ségrégation « raciale » dont sont victimes les Noirs qui explique leur localisation « inadéquate » par rapport aux lieux d'emploi. 
grande couronne en $1999^{7}$, contre respectivement $35 \%$ et $25 \%$ pour les cadres. Seuls $12 \%$ des domiciles et $21 \%$ des emplois ouvriers sont présents dans Paris intra-muros, contre $33 \%$ et $37 \%$ respectivement pour les cadres.

La dispersion des lieux de résidence et des lieux de travail des catégories populaires dans les zones périphériques peu denses accroît la distance qui sépare, en moyenne, les domiciles des emplois. Il s'ensuit naturellement une accessibilité à l'emploi réduite, puisque le nombre d'emplois accessibles dans un rayon donné tend à être plus faible que la moyenne. La carte 1, qui figure la part des emplois régionaux (pour les catégories sociales respectives) accessibles en une heure de déplacement en voiture depuis les communes de résidence franciliennes, souligne le poids de la géographie dans l'accessibilité à l'emploi différenciée des cadres et des ouvriers.

Deuxièmement, ce premier handicap est mécaniquement renforcé par le moindre accès des catégories populaires à la voiture, mode de transport qui permet les déplacements les plus rapides. La voiture a la particularité d'être le transport à la fois le plus coûteux financièrement et le moins coûteux en temps de parcours. La possibilité d'en disposer est donc déterminante en termes d'accessibilité mais reste discriminée par le niveau de revenu. En Ile-de-France, en 2001, la part des salariés disposant d'un " accès total ${ }^{8}$ » à la voiture n'excédait pas $48 \%$ des ouvriers et $43 \%$ des employés, alors que ceux qui ne disposaient d'aucun accès à la voiture atteignait $25 \%$ et $32 \%$. Ces parts étaient respectivement de $66 \%$ et $15 \%$ pour les cadres supérieurs. Le moindre accès à la voiture des classes populaires contribue à leur moindre accessibilité à l'emploi: plus souvent captifs des transports en commun alors même qu'ils sont plus susceptibles de se déplacer de banlieue à banlieue (compte tenu des lieux d'emploi et de résidence), trajets pour lesquels les transports collectifs sont moins performants, les ouvriers et employés sont contraints à des déplacements plus lents, ce qui réduit le périmètre spatial et donc les offres d'emplois qui leur sont accessibles en un temps de déplacement donné.

7. Année de référence de l'analyse empirique qui suit, à défaut de disposer des données nécessaires plus récentes.

8. Ces indicateurs sont produits à partir de l'Enquête Globale de Transports. On dit qu'un actif dispose d'un «accès nul » à la voiture quand il n'a pas le permis de conduire ou vit dans un ménage sans voiture. À l'opposé, l' « accès total » à la voiture correspond à la situation d'un actif qui, ayant le permis de conduire, vit dans un ménage comptant au moins autant de voitures que d'actifs. 
Les recherches empiriques ont établi, dans le cas francilien mais aussi ailleurs (notamment dans les villes nord-américaines), que les catégories populaires souffrent effectivement d'une moindre accessibilité à l'emploi. En Ile-de-France, Wenglenski ${ }^{9}$ a montré qu'en 1999, dans la limite d'un déplacement d'une heure et compte tenu de leurs chances d'utiliser la voiture, les ouvriers avaient accès, en moyenne, à $44 \%$ de l'emploi ouvrier régional, soit 20 points de moins que l'accessibilité moyenne pour les cadres supérieurs.

La sous-accessibilité à l'emploi des catégories populaires peut être un facteur explicatif de leur taux de chômage supérieur à la moyenne. Elle signifie que les ouvriers et employés bénéficient, en moyenne, d'une offre d'emploi accessible plus restreinte que les autres catégories. On peut alors s'attendre à des durées de chômage plus longues pour les ouvriers et employés à la recherche d'un emploi, ce qui, globalement, aura pour effet de tirer le taux de chômage de ces actifs vers le haut.

Outre-atlantique, la littérature autour de la «Spatial Mismatch Hypothesis » réunit un grand nombre de travaux testant le lien entre sous-accessibilité et sur-risque de chômage. Kain ${ }^{10}$, le premier, a montré, pour Chicago et Detroit, que le taux de chômage des Afro-américains serait moins élevé si ceux-ci n'étaient pas cantonnés aux ghettos du centre quand les emplois se développent en périphérie. Vingt ans plus tard, dans une large revue de littérature ${ }^{11}$, il pointe les limites méthodologiques des recherches (recensées avant lui par Jencks et Mayer ${ }^{12}$ ainsi que par Holzer $^{13}$ ) qui semblent invalider l'hypothèse d'un lien entre sous-accessibilité et sur-chômage. Dans les années 1990, les nouvelles recherches, employant des méthodes

9. Wenglenski Sandrine, "L'accessibilité au marché de l'emploi en Île-deFrance: une fonction de la catégorie sociale ", in Données urbaines, $\mathrm{n}^{\circ} 5$, Pumain Denise et Marie-Flore Mattei (dir.), Paris, Economica, 2007, p. 171-182.

10. KaIN John, «Housing Segregation, Negro Employment, and Metropolitan Decentralization », in The Quarterly Journal of Economics, Mai, Vol. 82, n 2, 1968, p. 175-197.

11. KaIN John, «The Spatial Mismatch Hypothesis: Three Decades Later », in Housing Policy Debate, no 3 (2), 1992, p. 371-460.

12. Jencks Christopher et Mayer Susan E., « Residential Segregation, Job Proximity, and Black Job Opportunities » \& " The social consequences of growing up in a poor neighbourhood ", in Inner-City Poverty in the United States, Lynn Laurence E. et Mcgeary Michael G.H. (dir.), Washington DC, The National Academy of Sciences, 1990, p. 187-216.

13. Holzer Harry J., « The spatial mismatch hypothesis: what has the evidence shown? », in Regional Studies, vol. 28, 1991, p. 105-122. 
Cadres

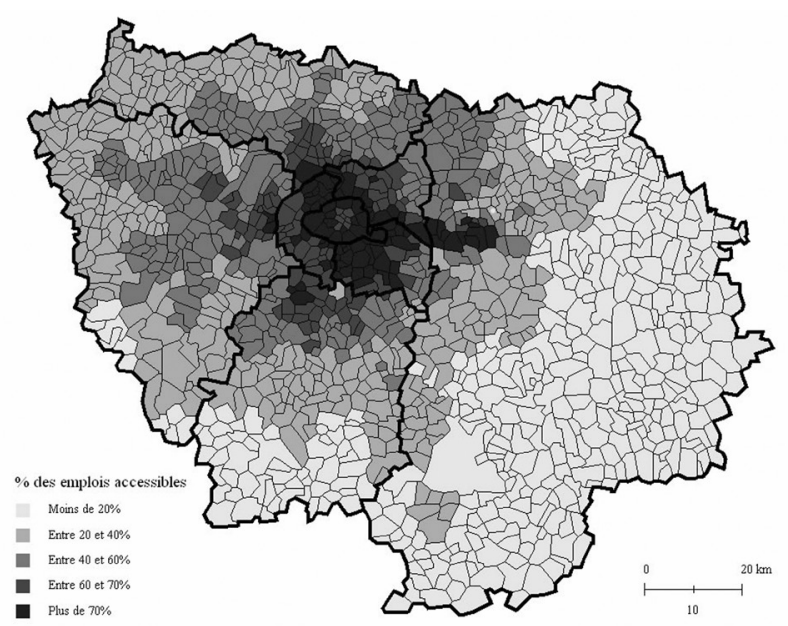

Ouvriers

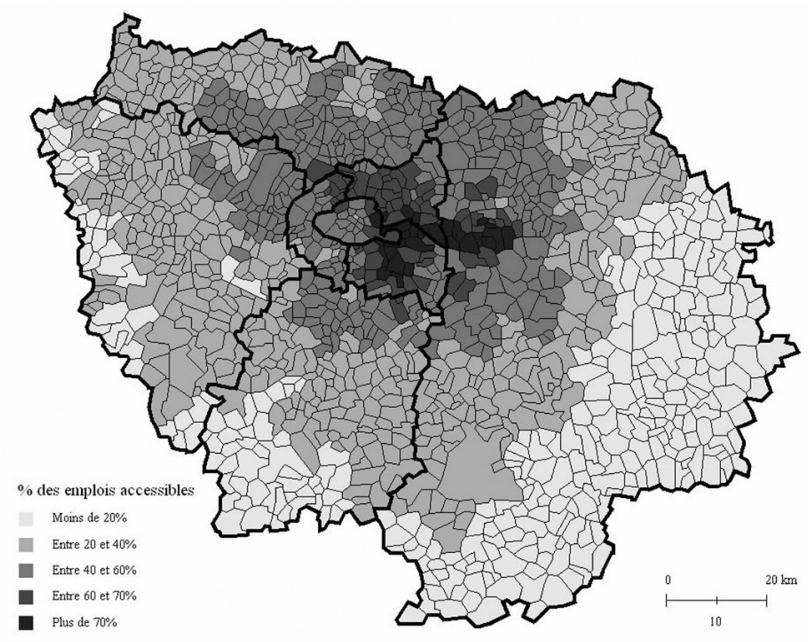

Fig. 1. Accessibilité à l'emploi des actifs franciliens en voiture* depuis leur commune de résidence

* Part des emplois régionaux de leur catégorie sociale, accessibles par des déplacements d'une heure ou moins, en 1999

Source: Calculs des auteurs, d'après INSEE RGP 1999, EGT 2001, DREIF 2000 
améliorées, donnent des résultats favorables à l'hypothèse de Kain ${ }^{14}$. Dans les années 2000, les approches se renouvellent et se diversifient: Hess ${ }^{15}$ prend en compte les modes de transport disponibles; Dawkins, Shen et

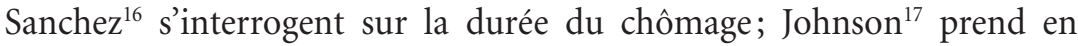
compte la compétition des actifs pour un même emploi. Les chercheurs européens se mettent à explorer la question dans le contexte du Vieux continent: en Angleterre sur des données désagrégées ${ }^{18}$ et en France sur la base de données agrégées le plus souvent ${ }^{19}$, avec des résultats qui valident généralement l'idée d'une corrélation entre niveau d'accessibilité à l'emploi et risque de chômage.

\section{Ségrégation et risque de chômage}

La division sociale de l'espace urbain est un second facteur urbain susceptible d'alimenter le chômage des catégories populaires. Le fonctionnement du marché du logement et les préférences des ménages en matière de choix résidentiel ont pour effet de concentrer une fraction importante des classes populaires dans les quartiers les plus dévalorisés de la ville. Dans un contexte où le chômage frappe un ouvrier non-qualifié sur cinq, cette concentration produit un environnement où chacun vit au contact quoti-

14. Ihlandfeld Keith et Sjoquist David, « The Spatial Mismatch Hypothesis: A Review of Recent Studies and Their Implications for Welfare Reform ", in Housing Policy Debate, $\mathrm{n}^{\circ} 9$ (4), 1998, p. 849-892; Ihlandfeld Keith et SJoquist David, " Job accessibility and racial differences in youth employment rates ", in American Economic Review, no 80, 1998, p. 267-276.

15. Hess Daniel, «Access to Employment for Adults in Poverty in the BuffaloNiagara Region ", in Urban Studies, no 42 (7), 2005, p. 1177-1200.

16. Dawkins Casey, Shen Qing, Sanchez Thomas, "Race, space, and unemployment duration », in Journal of Urban Economics, n 58 (1), 2005, p. 91-113.

17. Johnson Rucker C., « Landing a job in urban space: The extent and effects of spatial mismatch", in Regional Science and Urban Economics, n ${ }^{\circ} 36,2006$, p. 331-372.

18. Houston Donald, «Employability, Skills Mismatch and Spatial Mismatch in Metropolitan Labour Markets ", in Urban Studies, no 42 (2), 2005, p. 221-243; Fieldhouse Edward, « Ethnic minority unemployment and spatial mismatch: the case of London ", in Urban Studies, n 36, 1999, p. 1569-1596.

19. Voir Dujardin Claire, Selod Harris et Thomas Isabelle, « Le chômage dans l'agglomération bruxelloise: une explication par la structure urbaine », in Revue d'Économie Régionale et Urbaine, février 2004, p. 3-28; GobILLON Laurent et SELOD Harris, "Les déterminants spatiaux du chômage en Île-de-France », op. cit., p. 171187; Gaschet Frédéric et Gaussier Nathalie, « Ségrégation urbaine et marchés du travail au sein de l'aire urbaine... », op. cit. 
dien de la détresse économique et sociale. Pour plusieurs sociologues anglo-saxons, le fait de vivre dans un tel voisinage est un facteur de risque pour l'accès à l'emploi, et ce pour trois raisons ${ }^{20}$.

Une première raison renvoie aux conditions de socialisation des jeunes. Grandir dans les quartiers défavorisés, au contact quotidien de la pauvreté, du chômage et de l'insécurité, dans la proximité de groupes de pairs dont certains vivent dans la marginalité, voire dans la délinquance, risquerait de détourner les jeunes des normes dominantes et de les conduire vers une socialisation "déviante ». Sans un apprentissage et une intériorisation suffisants du système de normes, de valeurs et de codes comportementaux que transmet une socialisation "normale", ces jeunes rencontreraient, à l'heure de l'entrée dans la vie active, des difficultés spécifiques que le manque de capital scolaire seul n'explique pas.

La seconde raison découle des recherches établissant que les réseaux sociaux constituent une ressource capitale en tant que « relais vers l'emploi $^{21} »$. Dans ce rôle, le rendement d'un réseau social est proportionnel à la capacité de ses membres à faire circuler des informations sur les opportunités d'emploi ou à interférer auprès d'employeurs potentiels. Dans les quartiers défavorisés, la concentration de populations au chômage fait que chacun compte dans son entourage un grand nombre d'individus privés d'emploi, exclus du marché du travail et peu en mesure de détenir des informations sur les opportunités du marché du travail ou d'influencer les employeurs. Il s'ensuit que les réseaux sociaux bâtis dans ces quartiers sont susceptibles d'être peu productifs en tant que facilitateurs d'accès à l'emploi, ce qui risque de compliquer encore davantage les sorties de chômage.

La troisième raison met en avant les stigmates subis par les quartiers défavorisés et leurs habitants. Les classes populaires des quartiers défavorisés subiraient, dans l'accès à l'emploi, les conséquences de la mauvaise réputation dont sont porteurs ces quartiers dans les représentations collectives. Associant les quartiers défavorisés à des univers pathogènes et délictueux, certains employeurs exprimeraient une franche aversion envers les candidats à l'embauche provenant de ces quartiers.

Les recherches empiriques consacrées aux effets de quartier sont abondantes dans les domaines de l'échec scolaire, des problèmes de santé ou des comportements déviants mais plus rares dans le domaine de l'accès à l'em-

20. Sur ce point, voir Massey Douglas et Denton Nancy, American Apartheid, Paris, Descartes et Cie, 1995.

21. Granovetter Marc, "The Strength of Weak Ties ", in American Journal of Sociology, $\mathrm{n}^{\circ} 78$ (6), 1973, p. 1360-1380. 
ploi. Toutefois, ces rares travaux semblent valider l'hypothèse d'effets négatifs dans les quartiers pauvres. Datcher ${ }^{22}$ puis Corcoran et al ${ }^{23}$. ont trouvé une corrélation, toutes choses égales par ailleurs, entre la composition ethnique du quartier et le niveau de salaire des jeunes Noirs. Massey et Denton $^{24}$ et $\mathrm{O}^{\prime}$ Reagan et Quigley ${ }^{25}$ ont montré que la probabilité des jeunes adultes d'être employés décroît avec le taux de pauvreté du quartier. Le suivi des bénéficiaires du Programme Gautreaux (système d'allocation logement en direction des familles déménageant des inner-cities pauvres vers des quartiers de banlieue plus aisés) a permis de confirmer ces résultats, en témoignant de l'amélioration du sort des familles ayant déménagé comparativement à celui des familles qui sont restées dans les quartiers pauvres du centre ${ }^{26}$.

Dans les années 2000, on a également vu le développement de recherches européennes sur ces questions. Musterd et $a l^{27}$., Van der Klaauw et Van Ours $^{28}$ ou Brännström ${ }^{29}$, pour ne citer que quelques travaux, ont observé le lien entre le profil du voisinage et la longueur des périodes de transition entre chômage et emploi. En France, les deux seules recherches existantes donnent des résultats divergents. Pour Marpsat et Laurent ${ }^{30}$, les caractéris-

22. Datcher Linda, «Effects of Community and Family Background on Achievement ", in The Review of Economics and Statistics, $\mathrm{n}^{\circ} 64$ (1), 1982, p. 32-41.

23. Corcoran Mary et al., Effects of Family and Community Background on Men's Economic Status, NBER Working Paper 2896, Cambridge (MA), National Bureau of Economic Research, 1989, 26 pages.

24. Massey Douglas et Denton Nancy, American Apartheid, op. cit.

25. O'Reagan Katherine et Quigley John, « Where Youth Live: Economic Effects of Urban Space on Employment Prospects ", in Urban Studies, n 35 (7), 1998, p. 1287-1305.

26. Mendenhall Ruby et al, "Neighborhood Resources, Racial Segregation, and Economic Mobility", in Social Science research, 2006, p. 892-923; Fauth Rebecca et al., "Short-term effects of moving from public housing in poor to middle-class neighbourhoods on low-income, minority adults' outcomes ", in Social Science \& Medicine, n 59, 2004, p. 2271-2284.

27. Musterd Sako et al, "Environmental effects and social mobility », in Housing Studies, $1 \mathrm{n}^{\circ} 8$ (6), 2003, p. 877-892.

28. Van Der Klaauw Bas et Van Ours Jan, «From welfare to work: does the neighbourhood matter? ", in Journal of Public Economics, n 87, 2003, p. 957-985.

29. BRÄnnström Lars, « Poor Places, Poor Prospects? Counterfactual Models of Neighbourhood Effects on Social Exclusion in Stockholm, Sweden ", in Urban Studies, $\mathrm{n}^{\circ} 41$ (13), 2004, p. 2515-2537.

30. Marpsat Maryse et Laurent Raphaël, « Le chômage des jeunes est-il aggravé par l'appartenance à un quartier en difficulté? », op. cit. 
tiques sociales du quartier ne semblent pas peser sur la chance d'être employé pour les jeunes adultes qui y résident; pour Choffel et Delattre ${ }^{31}$, chez les demandeurs d'emploi, à caractéristiques identiques, la probabilité d'être toujours au chômage au bout d'un laps de temps donné est plus élevée dans les quartiers pauvres classés Zones Urbaines Sensibles.

\section{Méthodologie D’EXPLORATION}

\section{Données et méthode d'analyse}

La méthode que nous avons utilisée est classique dans ce type de recherches. À l'aide de techniques de régression logistique, on a estimé le risque de chômage des actifs selon les caractéristiques de leur lieu de résidence en termes d'accessibilité et d'environnement social, tout en contrôlant les autres variables susceptibles d'agir. Les données proviennent du fichier détail du Recensement Général de la Population de 1999. Le recours à cette source présente plusieurs avantages et singularise notre recherche par rapport aux recherches empiriques françaises antérieures. Cela permet (i) de travailler avec des données individuelles (plus adaptées à la problématique que les données agrégées), (ii) de disposer d'un large échantillon (notre analyse porte sur 55400 observations) ce qui réduit considérablement les risques d'erreur dus aux aléas de l'échantillonnage, et enfin, (iii) de restreindre le champ spatial de l'analyse à une agglomération unique (région Ile-de-France) et d'éviter une analyse qui porte, par contrainte, sur la France entière, en ménageant dans un petit échantillon des contextes urbains très différents.

Conceptuellement, la démarche consiste à mesurer le lien statistique entre la variable à expliquer - la situation d'emploi des actifs (avoir un emploi/être au chômage) ${ }^{32}$ - et les variables explicatives spatiales - les caractéristiques du lieu de résidence en termes d'accessibilité et d'environ-

31. Choffel Philippe et Delattre Éric, « Habiter un quartier défavorisé: quels effets sur la durée de chômage? ", op. cit.

32. Dans les recherches antérieures pré-citées, la variable à expliquer varie selon les analyses. Dujardin, Selod et Thomas («Le chômage dans l'agglomération bruxelloise: une explication par la structure urbaine ", op. cit.) ainsi que Marpsat et Laurent ( « Le chômage des jeunes est-il aggravé par l'appartenance à un quartier en difficulté? »,op. cit.), comme nous, estiment la probabilité pour un actif d'être au chômage à un instant $t$. Choffel et Delattre ( «Habiter un quartier défavorisé: quels effets sur la durée de chômage? »,op. cit.) estiment la probabilité, pour un actif au chômage à l'instant $\mathrm{t}$, d'être toujours au chômage à l'instant $\mathrm{t}+1$. Gaschet et Gaussier ("Ségrégation urbaine et marchés du travail au sein de l'aire urbaine...", 
nement social - «toutes choses égales par ailleurs », c'est-à-dire en neutralisant l'effet éventuel des autres variables actives - les caractéristiques individuelles. Nous avons conduit une analyse de régressions pour établir ${ }^{33}$ ce lien pour le groupe des catégories supérieures (cadres et professions intellectuelles supérieures et professions intermédiaires) d'une part, et pour les catégories populaires (employés et ouvriers) d'autre part.

\section{Champ et variables observés}

Le champ de l'analyse inclut les seuls actifs, personnes de référence et conjoints, qui ont un profil de salarié non-fonctionnaire (d'après la catégorie socio-professionnelle renseignée par le Recensement): les professions libérales et les salariés de la fonction publique n'étant pas soumis aux mêmes modalités en termes de recrutement et de chômage ont été écartés. On ne retient également que les personnes résidant en 1999 dans le même logement qu'en 1990, ce qui nous permet d'observer les seuls actifs ayant vécu durablement au lieu de résidence où ils sont recensés et qui sont susceptibles par conséquent d'en avoir réellement subi l'influence. Cette condition est aussi favorable à l'analyse de l'influence de l'accessibilité car elle accroît la probabilité que les personnes qui ont un emploi l'aient effectivement cherché et trouvé depuis leur domicile actuel.

Les variables de contrôle retenues sont l'âge, le sexe, la catégorie socioprofessionnelle (en huit modalités d'après la nomenclature des PCS en 24 postes de l'INSEE), le niveau d'études/dernier diplôme obtenu, la nationalité/pays de naissance.

Les variables relatives à l'environnement social du lieu de résidence et à l'accessibilité à l'emploi sont présentées dans le tableau 1. La variable « accessibilité à l'emploi » est construite à partir d'un indicateur quantitatif. Celui-ci exprime, pour un actif francilien d'une catégorie sociale donnée et habitant une commune donnée, la part des emplois régionaux de sa catégorie qui lui sont accessibles, en moyenne, depuis son domicile au terme de déplacements d'une heure au maximum, en transports en commun ou en voiture selon la disposition qu'il en $\mathrm{a}^{34}$. Sur la base de cet indi-

op. cit.) et de Gobillon et Selod ( « Les déterminants spatiaux du chômage en Île-deFrance », op. cit.) veulent expliquer le taux de chômage communal.

33. La variable à expliquer comme les variables explicatives sont conçues sous forme de variables discrètes dichotomiques.

34. Les temps de transport en voiture et en transports collectifs entre toutes les origines et destinations franciliennes sont donnés par des modélisations de la DREIF; les emplois (qui ne sont pas les emplois vacants, mais les emplois occupés) 
cateur, les actifs sont classés en cinq catégories selon leur niveau d'accessibilité.

Cet indicateur d'accessibilité offre des avantages par rapport à ceux de certaines recherches antérieures. Certains, fondés sur les caractéristiques des déplacements domicile-travail accomplis par les actifs occupés, ont l'inconvénient d'affecter aux chômeurs des possibilités de déplacement déduites des pratiques de déplacement des détenteurs d'emploi, alors même qu'on peut penser que les potentiels des premiers diffèrent de ceux des seconds (en l'occurrence concrétisés par des pratiques). D'autres mesurent un potentiel d'accès à l'emploi mais de manière plus approximative (taux d'emploi de la commune de résidence ou distance moyenne aux emplois de la commune de résidence).

La variable liée à l'environnement social de la commune de résidence est conçue à l'échelle des quartiers IRIS. Elle est construite à partir de données portant sur le chômage (taux de chômage calculé à partir du Recensement de la population de 1999) et sur les revenus des ménages ( $1^{\text {er }}$ décile de la distribution des revenus imposables par unité de consommation du ménage dans le quartier en 2001 d'après la Direction Générale des Impôts). Les quartiers et les communes sont classés selon leur "score » d'après cet indicateur composite ${ }^{35}$, des plus défavorisés aux plus favorisés, puis regroupés en cinq catégories. Les communes (périurbaines) de petite taille pour

sont connus à l'échelle communale par le Recensement. Pour la présentation de l'indicateur de base, voir: WeNGLENSKI Sandrine, "L'accessibilité au marché de l'emploi en Île-de-France: une fonction de la catégorie sociale", in Données urbaines, $\mathrm{n}^{\circ}$ 5, Pumain Denise et Marie-Flore Mattei (dir.), Paris, Economica, 2007, p. 171-182. Dans la présente analyse, l'affectation d'un mode de transport pour le calcul de l'accessibilité repose sur un certain nombre de postulats. D'une part, on fait l'hypothèse que les personnes « disposant d'une voiture " pourraient s'en servir pour aller travailler et on leur affecte une accessibilité calculée à partir de déplacements en voiture. Pour les autres, l'accessibilité est calculée à partir de déplacements en transports en commun. D'autre part, la " disposition d'une voiture » est établie à partir des variables disponibles dans le Recensement de la manière suivante: quand il y a au moins autant de voitures que d'actifs au sein du ménage, chacun est supposé disposer d'une voiture; quand il n'y a pas de voiture, aucun n'est supposé disposer d'une voiture (et chacun se déplace donc en transports en commun). Quand il y a une seule voiture pour deux actifs, soit les deux actifs sont occupés et la voiture est affectée à celui qui déclare s'en servir pour aller travailler; soit l'un est au chômage et elle est affectée à l'actif occupé s'il déclare s'en servir, au chômeur sinon; soit les deux actifs sont chômeurs et la voiture est affectée à la personne de référence.

35. L'indicateur composite est obtenu en deux étapes: (i) calcul des écarts centrés-réduits pour les distributions relatives aux deux variables (taux de chômage et 
lesquelles aucune information sur les revenus n'est disponible sont regroupées dans une catégorie à part («Autre»).

Fig. 2. Répartition des actifs franciliens selon leur accessibilité à l'emploi et le profil social du quartier en 1999

\begin{tabular}{|c|c|c|c|c|c|}
\hline $\begin{array}{l}\text { Accessibilité à } \\
\text { l'emploi }\end{array}$ & \multicolumn{3}{|c|}{$\begin{array}{c}\text { Part de l'emploi régional accessible en une heure compte } \\
\text { tenu de l'accès aux modes de transport }(\%)\end{array}$} & $\begin{array}{l}\text { Cadres et prof. } \\
\text { Intermédiaires }(\%)\end{array}$ & $\begin{array}{l}\text { Employés et } \\
\text { ouvriers }(\%)\end{array}$ \\
\hline Très bonne & \multicolumn{3}{|c|}{ Plus de $70 \%$ des emplois de la catégorie } & 23,9 & 14,0 \\
\hline Bonne & \multicolumn{3}{|c|}{ Entre $60 \%$ et $70 \%$ des emplois de la catégorie } & 24,8 & 22,1 \\
\hline Moyenne & \multicolumn{3}{|c|}{ Entre $40 \%$ et $60 \%$ des emplois de la catégorie } & 31,5 & 35,8 \\
\hline Médiocre & \multicolumn{3}{|c|}{ Entre $20 \%$ et $40 \%$ des emplois de la catégorie } & 14,2 & 17,4 \\
\hline Mauvaise & \multicolumn{3}{|c|}{ Moins de $20 \%$ des emplois de la catégorie } & 5,6 & 10,7 \\
\hline $\begin{array}{l}\text { Environnement } \\
\text { social }\end{array}$ & \multicolumn{2}{|c|}{$\begin{array}{cc}\begin{array}{c}\text { Part de la } \\
\text { population }\end{array} & \begin{array}{c}\text { ler décile des } \\
\text { revenus annuels }\end{array} \\
\text { francilienne }(\%) & \text { par uc }(€)\end{array}$} & $\begin{array}{l}\text { Taux de chômage } \\
\text { communal }(\%)\end{array}$ & 100,0 & 100,0 \\
\hline Favorisé & 35,1 & 10626,60 & 8,1 & 43,9 & 26,9 \\
\hline Moyen & 19,8 & 7354,30 & 11,0 & 20,2 & 18,6 \\
\hline Médiocre & 19,5 & 5183,10 & 14,7 & 17,3 & 21,6 \\
\hline Défavorisé & 10,4 & 3747,30 & 20,0 & 7,7 & 13,3 \\
\hline Très défavorisé & 10,5 & 2652,80 & 31,9 & 4,9 & 14,1 \\
\hline Autre* & 4,8 & - & - & 6,0 & 5,4 \\
\hline
\end{tabular}

Source : calculs des auteurs d'après INSEE RGP 1999, Direction Générale des Impôts 2001, DREIF 2000.

Champ : personnes résidant en Île-de-France en 1999 dans le même logement qu'en 1990 ; actifs de catégorie (1) cadre, profession intermédiaire, (2) employé ou ouvrier ; non agriculteur, artisan, profession libérale, fonctionnaire ou intermitant.

* Autre : espaces pour lesquels l'information sur le revenu n'est pas disponible à l'échelle des quartiers pour des raisons de taille de population et de règle de secret statistique (petites communes périurbaines).

Lecture : $23,9 \%$ des cadres et professions intermédiaires du champ de l'analyse bénéficient d'une très bonne accessibilité aux emplois de leur catégorie sociale respective, contre $14 \%$ des employés et ouvriers. $43,9 \%$ des cadres et professions intermédiaires du champ de l'analyse vivent dans une commune où l'environnement social est favorisé, contre $26,9 \%$ des employés et ouvriers ; dans ces quartiers favorisés, les $10 \%$ d'individus les moins riches économiquement vivent dans des ménages où le revenu annuel imposable est supérieur en moyenne à 10 626,6 euros par unité de consommation et le taux de chômage moyen est de 8,1 contre $31,9 \%$ dans les quartiers très défavorisés.

\section{RÉSULTATS DES ANALYSES}

Au terme des analyses, la double hypothèse sur le rôle de variables spatiales sur le risque de chômage est validée: l'exposition à un environnement social défavorisé et une moindre accessibilité à l'emploi semblent bien accroître le risque de chômage.

Les modèles testés (tableau 2) sont globalement cohérents - les tests statistiques donnent des résultats satisfaisants - significatifs et plutôt perfor-

ler décile de la distribution des revenus); (ii) addition des deux écarts centrésréduits pour chaque quartier/commune. 
mants -, la capacité des modèles à prédire le chômage est non-négligeable (taux de prédictions concordantes de $62 \%$ et $63 \%$ ). La plupart des variables explicatives individuelles présentent les signes attendus et des coefficients significatifs (toutes choses égales par ailleurs, risques de chômage plus élevés pour les actifs les plus jeunes et les plus âgés, les femmes, les étrangers) à l'exception de l'effet du diplôme et de la catégorie sociale pour les employés et ouvriers (leur double prise en compte apparaît responsable de ce brouillage: menée sans la catégorie sociale, l'analyse redonne sa place traditionnelle au diplôme).

\section{L'accessibilité à l'emploi influence le risque de chômage}

L'analyse statistique révèle que, toutes choses égales par ailleurs, le risque de chômage varie significativement avec le niveau d'accessibilité à l'emploi depuis le lieu de résidence dans le sens attendu. Plus l'accessibilité des actifs aux emplois est forte, meilleure est leur probabilité d'avoir un emploi. Notons cependant que les coefficients estimés ne sont pas ou peu significatifs et qu'il semble exister un palier au-delà duquel la relation achoppe.

Pour l'actif-type ${ }^{36}$ des catégories supérieures, la probabilité d'être au chômage s'élève à $9,18 \%$ quand ils ont une très faible accessibilité, passe à $7,15 \%$ pour une accessibilité "médiocre » et atteint $8,26 \%$ et $8,17 \%$ quand elle est « bonne » et " très bonne ». Il y a donc une plus forte propension à être au chômage en cas de mauvaise accessibilité, mais on observe que cette propension est supérieure dans les contextes de bonne et très bonne accessibilité que quand l'accessibilité est simplement moyenne ou médiocre. Pour l'actif-type des classes populaires, la probabilité d'être au chômage décroît également de 13,29 \% depuis une situation de "mauvaise " accessibilité jusqu'à 10,44 \% pour une «très bonne » accessibilité. Là encore, néanmoins, on constate qu'une "bonne » accessibilité ne prémunit pas davantage du chômage qu'une « très bonne » accessibilité.

36. L'actif-type correspond à l'individu qui présente les caractéristiques de référence dans l'analyse de régression. Il s'agit d'un homme, entre 35 et 50 ans, français né en France métropolitaine, habitant une commune depuis laquelle l'accessibilité à l'emploi est «bonne » et dans un quartier où le profil social est «moyen ». Pour les catégories moyennes et supérieures, il est diplômé d'un bac +2 et de profession intermédiaire administrative d'entreprise. Pour les catégories populaires, il s'agit d'un homme ayant les mêmes caractéristiques mais détenteur du bac ou bac+2 et employé administratif d'entreprise. 


\section{L'exposition à un environnement social défavorisé accroît le risque de chômage}

S'agissant du lien statistique entre le risque de chômage et les caractéristiques sociales du quartier de résidence, les résultats suggèrent que l'exposition à un environnement social défavorisé produit bien un effet tangible et négatif sur les chances d'avoir un emploi, ce qui corrobore l'hypothèse de départ. Pour les deux groupes d'actifs (cadres et professions intermédiaires d'une part, employés et ouvriers d'autre part), le risque de chômage croît avec le degré de pauvreté et de chômage observé dans le quartier de résidence, mais plus encore pour les catégories modestes.

Pour l'actif-type de catégorie supérieure, la probabilité d'être au chômage, qui s'élève à $7,47 \%$ dans les quartiers "favorisés", progresse à mesure que le profil socio-économique du quartier de résidence se dégrade: elle s'établit à $8,26 \%$ dans les quartiers où l'environnement social est " moyen »; s'élève à $9,5 \%$ dans les quartiers où l'environnement social est "défavorisé » et monte jusqu'à 11,32 \% dans les quartiers " très défavorisés ». Autrement dit, pour l'actif-type, le risque d'être au chômage croît de moitié, lorsque celui-ci habite un quartier très défavorisé plutôt qu'un quartier favorisé. Néanmoins, les coefficients estimés ne sont pas significatifs pour des risques d'erreur inférieurs à $5 \%$.

Pour les employés et ouvriers, le lien entre le risque de chômage et les caractéristiques sociales du quartier de résidence est plus fort et plus significatif. Pour l'actif-type, la probabilité d'être au chômage varie du simple au double entre les quartiers favorisés et les quartiers très défavorisés: de $9,17 \%$ dans les premiers à 18,8\% dans les seconds. Les actifs des catégories populaires apparaissent ainsi beaucoup plus sensibles à l'effet de l'environnement social sur leur devenir professionnel.

Au regard de ces résultats, résider durablement dans un quartier exposé fortement à la pauvreté et au chômage semble bien aggraver les conditions d'accès à l'emploi. Toutes choses égales par ailleurs, les actifs semblent passer plus souvent par le chômage et/ou y rester plus longtemps lorsqu'ils résident dans des environnements sociaux difficiles plutôt qu'en quartiers plus ordinaires ou plus favorisés. Mais les catégories populaires apparaissent plus vulnérables que leurs homologues cadres ou professions intermédiaires: les externalités négatives qui les touchent dans les quartiers défavorisés sont encore plus pénalisantes et leur risque de se trouver durablement dans de tels quartiers producteurs d'effets négatifs sont bien plus grands. 
Fig. 3. Probabilités estimées de risque de chômage selon les caractéristiques individuelles et les caractéristiques du lieu de résidence en 1999

\begin{tabular}{|c|c|c|c|c|c|}
\hline & \multicolumn{2}{|c|}{ Cadres et prof.intermédiaires } & \multicolumn{3}{|c|}{ Employés et ouvriers } \\
\hline & Significatitivté & $\begin{array}{l}\text { Probabilité estimée } \\
\text { d'être au chômage } \\
(\%)\end{array}$ & Significatitivté & $\begin{array}{l}\text { Probabilité estimée } \\
\text { d'être au chômage (\%) }\end{array}$ & \\
\hline \multirow{2}{*}{\multicolumn{6}{|c|}{ Sexe }} \\
\hline & & & & & \\
\hline Femme & $\begin{array}{l}\text { Rej. } \\
\text { ns }\end{array}$ & $\begin{array}{l}8,20 \\
8,37\end{array}$ & $\begin{array}{l}\text { Rej. } \\
* * * * *\end{array}$ & 12.95 & \\
\hline \multicolumn{6}{|l|}{ Âge } \\
\hline Moins de 25 ans & ns. & 6,19 & ***** & 19,40 & \\
\hline De 25 à 35 ans & $* *$ & 10,16 & $* * * *$ & 15,43 & \\
\hline De 35 à 50 ans & Réf. & 8,26 & Réf. & 11,22 & \\
\hline Plus de 50 ans & $* * * *$ & 13,20 & ***** & 14,72 & \\
\hline $\begin{array}{l}\text { Dernier diplôme obtenu pour les cadres et } \\
\text { prof.intermédiaires }\end{array}$ & \multicolumn{5}{|c|}{$\begin{array}{r}\text { Dernier diplôme obtenu pour les employés et } \\
\text { ouvriers }\end{array}$} \\
\hline Sans le Baccalauréat & ns. & 8,12 & **a* & 12,81 & Sans diplôme \\
\hline Baccalauréat général & **** & 10,66 & *** & 10,05 & CEP, ВEPC, CAP, ВEP \\
\hline Diplôme de ler cycle & Réf. & 8,26 & Réf. & 11,22 & Bac. ou diplôme univ.de ler cycle \\
\hline Diplôme de 2ème ou 3ème cycle & $* * *$ & 10,50 & $* *$ & 13,68 & Diplôme de 2ème ou 3ème cycle \\
\hline $\begin{array}{l}\text { Catégorie socioprofessionnelle pour les cadres et } \\
\text { prof.intermédiaires }\end{array}$ & \multicolumn{5}{|c|}{$\begin{array}{r}\text { Catégorie socioprofessionnelle pour les employés et } \\
\text { ouvriers }\end{array}$} \\
\hline Cadres admin. et com. d'entreprises & $* * * *$ & 4,95 & $*$ & 12,13 & Ouvrier qualifié \\
\hline Ingénieurs et cadres techniques d'entr. & $* * * *$ & 3,48 & $* * * *$ & 9,10 & Ouvrier non qualifié \\
\hline Profes. interméd. admin. et com. d'entr. & Réf. & 8,26 & Réf. & 11,22 & Employés admin.d'entr. \\
\hline Techniciens, agents de maitrise & $* * * *$ & 5,66 & $* * * *$ & 8,11 & Personnel de serv.et com. \\
\hline \multicolumn{6}{|l|}{ Nationalité/Pays de naissance } \\
\hline Français né à l'étranger ou en DOM/TOM & $* * * *$ & 12,76 & $* * * *$ & 15,48 & \\
\hline Français né en France métropolitaine & Réf. & 8,26 & Réf. & 11,22 & \\
\hline Etranger né en France & $* *$ & 19,95 & $* * * *$ & 19,98 & \\
\hline Etranger né à l'étranger & ***** & 15,38 & ***** & 14,61 & \\
\hline \multicolumn{6}{|c|}{ Accessibilité aux emplois de la catégorie sociale depuis la commune de résidence } \\
\hline Mauvaise & ns. & 9,18 & **** & 13,29 & \\
\hline Médiocre & * & 7,15 & ns. & 11,03 & \\
\hline Moyenne & $* *$ & 7,19 & ns. & 10,79 & \\
\hline Bonne & Réf. & 8,26 & Réf. & 11,22 & \\
\hline Très bonne & ns. & 8,17 & ns. & 10,44 & \\
\hline \multicolumn{6}{|l|}{ Environnement social du quartier de résidence } \\
\hline Très défavorisé & ***** & 11,32 & ***** & 18,80 & \\
\hline Défavorisé & * & 9,50 & ***** & 15,29 & \\
\hline Médiocre & ns. & 8,70 & $* * * *$ & 13,73 & \\
\hline Moyen & Réf. & 8,26 & Réf. & 11,22 & \\
\hline Favorisé & $*$ & 7,47 & ****** & 9,17 & \\
\hline Autre & $* *$ & 6,41 & **** & 8,61 & \\
\hline
\end{tabular}

Source : Calculs des auteurs d'après INSEE, RGP 1999 et DREIF, matrice OD 2000

Champ de l'analyse : personnes de référence et conjoints résidant en Île-de-France en 1999 dans le même logement qu'en 1990, actifs de catégorie (1) cadre, profession intermédiaire, (2) employé ou ouvrier, non agriculteur, artisan, profession libérale, fo

$\begin{array}{lcccc}\text { Nombre d'individus } & \text { (1) } & 24529 & \text { (2) } & 30873 \\ \text { Effectif au chômage } & 2072 & & 4934 \\ \text { Pourcentage de prédictions concordantes } & 63,0 \% & & 62,3 \%\end{array}$

Pourcentage de prédictions concordantes

Note : ****: Significatif avec un risque d'erreur inférieur à $0,1 \% ; * * *$ : Significatif avec un risque d'erreur de $1 \% ; * *$ : Significatif avec un risque d'erreur de $5 \%$; : Significatif avec un risque d'erreur de $10 \%$; ns.: non-significatif pour un risque

L'individu de référence est un homme actif, entre 35 et 50 ans, français né en France métropolitaine, habitant un quartier de profil social moyen (où le taux de chômage moyen s'élève à $11 \%$ et les $10 \%$ d'individus les plus pauvres disposent de revenus annuels inférieurs à 7350 euros par unité de consommation) et bénéficiant d'une bonne accessibilité à l'emploi ( $60 \%$ à $70 \%$ des emplois accessibles en $1 \mathrm{~h}$ de déplacement). Dans le groupe des cadres et professions intermédiaires, l'individu est de profession intermédiaire administrative, diplômé d'un bac +2 ; dans le groupe des employés et ouvriers, l'individu est employé administratif, détenteur d'un bac ou bac+2.

Lecture : l'individu de référence du groupe des cadres et professions intermédiaires a 8,26\% de probabilité d'être au chômage ; l'individu de références du groupe des employés et ouvriers a $11,22 \%$ de probabilité d'être au chômage.

\section{DisCUSSION SUR L'INTERPRÉTATION DES RÉSULTATS}

L'analyse statistique du lien entre la situation d'emploi des actifs franciliens et les caractéristiques de leur lieu de résidence indique que le risque de 
chômage est (i) positivement corrélé au degré d'exposition à un environnement social défavorisé, notamment pour les employés et ouvriers, et (ii) qu'il ne semble pas indépendant de l'accessibilité aux opportunités d'emploi, bien qu'ici dans une relation de faible significativité statistique et non totalement linéaire. Comment interpréter ces résultats?

En premier lieu, on peut considérer que ce qu'ils suggèrent est conforme à la réalité: disposer d'une faible accessibilité ou résider dans un quartier défavorisé augmentent significativement le risque de chômage.

En effet, il paraît plausible que les situations de sous-accessibilité en Ilede-France soient de nature à compliquer l'accès à l'emploi des actifs, mais non de façon stricte et linéaire. D'un côté, l'étalement urbain qui caractérise l'aire urbaine de Paris depuis plusieurs décennies différencie les localisations résidentielles en termes de proximité aux lieux d'emploi. En outre, si l'accès à la voiture s'est massivement généralisé, il demeure différencié entre actifs et (du fait de vitesses de déplacement supérieures en moyenne à celles des transports en commun) discrimine mécaniquement le périmètre spatial qu'il permet d'atteindre. Dans ce contexte, l'accessibilité des actifs se traduit en des volumes d'emplois accessibles très inégaux. Il est donc très vraisemblable que des tailles de marché de l'emploi variant dans un rapport de 1 à 3 soient corrélées à des difficultés à trouver un emploi également graduées. D'un autre côté, cependant, il est également vraisemblable que, du fait d'un système de transports publics suffisamment efficace et d'une dispersion des emplois encore contenue, les accessibilités moyennes ou médiocres assurent aux Franciliens un marché de l'emploi déjà suffisamment substantiel pour ne pas leur être plus préjudiciables qu'une bonne accessibilité.

De même, concernant l'effet de l'environnement social sur le risque de chômage, on peut considérer que les résultats de nos analyses sont recevables. Les quartiers franciliens que nous avons classés « quartiers très défavorisés " sont effectivement des territoires où la pauvreté et le chômage sont répandus: une personne sur dix y vit dans un ménage disposant de moins de 2700 euros de revenus imposables annuels (240 euros par mois) par unité de consommation et près d'un actif sur trois est touché par le chômage. Les résultats de nos analyses suggéreraient donc qu'on a affaire là à des quartiers défavorisés au point que les mécanismes évoqués précédemment (où pauvreté et chômage des uns peuvent être un handicap pour les autres) y sont réellement à l'œuvre et que l'exposition durable à l'environnement de ces quartiers pénalise effectivement leurs habitants dans l'accès à l'emploi. 


\section{Risques de biais méthodologiques}

Mais il faut aussi souligner un certain nombre de limites méthodologiques de l'analyse susceptibles de mettre en cause la validité et le sens des résultats obtenus.

S'agissant des analyses portant sur l'effet de l'accessibilité, il y a un risque que l'indicateur d'accessibilité élaboré mesure mal l'accessibilité réelle. Il est vrai que celui-ci (i) néglige la question des représentations subjectives de la distance (sentiment de légitimité à occuper et à parcourir les espaces, par exemple), (ii) distingue trop grossièrement les catégories d'emplois, (iii) mesure l'accessibilité à l'aune de l'ensemble des emplois occupés, et non des emplois à pourvoir ${ }^{37}$ et (iv) ceci sur la base d'hypothèses contestables (par exemple, compte tenu des coûts élevés de son utilisation, la disposition d'une voiture ne signifie pas automatiquement la possibilité d'en faire un usage quotidien pour se rendre au travail).

Le risque de biais est également associé à l'usage de méthodes statistiques dont la finalité est de pouvoir dégager des résultats « toutes choses égales par ailleurs ». Une des faiblesses de ces méthodes est de s'exposer à d'importants biais de sélection. Les résultats de nos analyses suggèrent que deux individus de même profil social mais résidant dans des quartiers différents en termes d'environnement social encourent des risques de chômage inégaux. Cette démarche occulte le fait que deux individus habitant deux quartiers différents de la ville ne sont sans doute jamais identiques socialement, la différence de leurs lieux de résidence révélant précisément leurs différences sociales. Pour l'individu qui réside dans le quartier défavorisé, cette localisation résidentielle a une forte probabilité de traduire une position sociale relative inférieure, en dépit de l'apparence des caractéristiques observées, et dont l'explication réside dans des caractéristiques «cachées" (moindres ressources économiques, sociales ou symboliques, origine sociale plus modeste, absence de patrimoine familial, statut familial, etc.). Il est alors possible que ce que l'on assimile à un effet « environnemental », lié au rôle d'un environnement social défavorisé, ne soit en vérité qu'un effet « social»

37. Dans leur recherche sur Bordeaux, Gaschet et Gaussier (« Ségrégation urbaine et marchés du travail au sein de l'aire urbaine... ", op. cit.) tentent de déjouer ce problème en recourant à des données qui cependant en posent d'autres, les offres d'emploi enregistrées par l'ANPE ne représentant approximativement qu'un quart de l'offre réelle du marché (JАYET Hubert, «Villes et marchés du travail », op. cit.). 
supplémentaire. Il est difficile de se prémunir contre ce biais de sélection et, incontestablement, nos résultats en sont potentiellement affectés ${ }^{38}$.

Un biais semblable concerne nos analyses consacrées aux liens entre risque de chômage et accessibilité. La faible significativité statistique de ces liens et la hiérarchie inversée des taux de chômage qui caractérise les niveaux de "bonne» et "moyenne" accessibilité peuvent trouver leur explication dans un facteur "mobilité résidentielle » que nous ne maîtrisons que partiellement. En effet, le niveau d'accessibilité à l'emploi des actifs est pour partie fonction de la distance de la résidence au centre de l'agglomération. Or, les marges de l'agglomération sont la destination d'un grand nombre de ménages qui, une fois qu'ils bénéficient d'une situation d'emploi stable, viennent y concrétiser leur désir d'accès à la propriété d'une maison individuelle. Ainsi, le fait qu'à l'instant $t$, le risque de chômage paraisse plus faible malgré une moindre accessibilité à l'emploi peut s'expliquer par le fait que, pour une part, les actifs-résidents qu' on y recense n'ont pas trouvé leur emploi depuis ces localisations. On peut reproduire le raisonnement pour expliquer que la probabilité d'être au chômage apparaisse plus élevée dans les secteurs qui offrent une bonne accessibilité. C'est en effet dans ces secteurs, situés proches du cœur de l'agglomération, que se concentrent les logements sociaux et les logements vétustes du secteur privé, soit les deux formes de logement les plus susceptibles d'accueillir les actifs les plus mal insérés dans le marché du travail - logements et quartiers qu'ils sont susceptibles de quitter une fois obtenu un emploi stable.

On le voit bien, ces interdépendances entre situations d'emploi et trajectoires résidentielles compliquent sérieusement l'interprétation des résultats obtenus. On peut supposer que la restriction du champ de l'analyse aux seuls individus habitant leur commune depuis au moins neuf ans

38. On trouve, dans les recherches antérieures, des tentatives méthodologiques pour le déjouer mais le remède n'apparaît pas toujours idoine. Dujardin, Selod et Thomas («Le chômage dans l'agglomération bruxelloise: une explication par la structure urbaine », op. cit.), par exemple, proposent de restreindre le champ de l'analyse aux seuls jeunes actifs résidant encore chez leurs parents. Une telle restriction aurait pour effet de neutraliser le biais de sélection dans la mesure où le choix de localisation résidentielle devient alors exogène aux individus retenus pour l'analyse (puisque le choix du lieu de résidence n'est pas accompli par les jeunes euxmêmes). D'après les auteurs, dans ces conditions, puisque les localisations résidentielles peuvent être considérées comme «aléatoires " (au sens où les jeunes n'y sont pour rien), le biais de sélection se trouve neutralisé. D'un point de vue sociologique, l'efficacité de cette astuce paraît sujette à caution car il revient à postuler que l'identité sociale des enfants est indépendante de celle des parents, ce qui est bien sûr très contestable. 
limite la portée de ce biais méthodologique ${ }^{39}$, mais il est difficile de savoir précisément dans quelle mesure. On peut conjecturer que le lien entre risque de chômage et accessibilité à l'emploi serait peut-être plus manifeste si le champ de l'analyse ne rassemblait pas l'ensemble des actifs à l'instant $t$ mais les seuls actifs au chômage à l'instant $t$ et dont on connaît la situation d'emploi à l'instant $t+k$ (accès à l'emploi ou poursuite du chômage). Il est possible, en effet, que l'effet de la moindre accessibilité sur le risque de chômage se manifeste davantage à condition de centrer l'observation sur le devenir des actifs à la recherche d'un emploi à l'instant $t$ et de se débarrasser ainsi du «bruit » introduit dans l'analyse par les actifs occupés dès le départ. Ce parti pris méthodologique, que l'on retrouve dans la recherche de Choffel et Delattre ${ }^{40}$, n'est malheureusement pas autorisé par les données du Recensement.

Une des pistes sans doute les plus fécondes pour évaluer le risque de biais de sélection qui pèse sur ces résultats ou pour tester le poids des représentations sur la définition d'une accessibilité individuelle passe par des recherches qualitatives, davantage monographiques. Des résultats convergents avec ceux de nos recherches quantitatives pourraient permettre de réduire les incertitudes que l'on a soulignées.

Emre Korsu, Sandrine Wenglenski Laboratoire Ville Mobilité Transport Université Paris-Est-Marne-La-Vallée

39. Car cela réduit la proportion des individus de l'échantillon dont l'entrée dans l'emploi actuel est antérieure à l'arrivée dans leur commune de résidence actuelle.

40. Choffel Philippe et Delattre Éric, « Habiter un quartier défavorisé: quels effets sur la durée de chômage? ", op. cit. 


\section{Spatial Justice through Regionalism? The Inside Game, the outside Game, and the Quest for the Spatial Fix in the U.S.}

Taake my word for it Sammy, the poor in a loomp is bad. From Tennyson, The Northern Farmer ${ }^{2}$

I

N THE 1960s, U.S. social scientists began a protracted debate about the causes of and remedies for urban poverty, a discussion that accelerated in the 1980s with the realization that new concentrations of poverty were developing. As the poverty research industry matured, it emphasized the role of contagion effects of place and the behavior of the poor in causing poverty, to the exclusion of macro-economic, structural factors ${ }^{3}$. Moreover, researchers and policymakers increasingly saw federal solutions to urban poverty as politically nonviable, due not only to a growing climate of devolution and neoliberalism, but also because of high-profile public policy disasters such as public housing. In this context, a new set of regional strategies to address inequity emerged by the 1990s, a movement alternatively called "new regionalism", or, more narrowly, "equity regionalism", "regional equity", or "progressive regionalism". Although varying in form,

1. This paper was presented at the "Justice et Injustices Spatiales" Conference in 2008 and was published with minor changes in a refereed journal: CHAPpLE Karen and Goetz Edward G., "Spatial justice through regionalism? The inside game, the outside game, and the quest for the spatial fix in the United States", in Community Development: Journal of the Community Development Society, vol. 42, $\mathrm{n}^{\circ} 4,2011$, p. $458-475$.

2. Quoted in Lund Brian, “'The poor in a loomp is bad': New labour and neighborhood renewal", in Political Quarterly, vol. 70, n 3, 1999, p. 280-284.

3. O'Connor Alice, Poverty Knowledge: Social Science, Social Policy, and the Poor in Twentieth-Century U.S. History, Princeton, Princeton University Press, 2001.

4. Bollens Scott, "In Through the Back Door: Social Equity and Regional Governance", in Housing Policy Debate, vol. 13, n 4, 2003, p. 631-657. 
each strategy essentially proposes a spatial fix by engaging the suburbs in solving the problem of urban poverty.

The equity regionalist program grows out of the initial awareness of urban-suburban disparity powerfully articulated by the Kerner Commission in 1968, with its warning that "Our nation is moving toward two societies, one black, one white - separate and unequal." The primary cause, as supported by research by John Kain ${ }^{5}$, was the shift of new employment opportunities to the suburbs and the lack of federal policies to connect urban residents, particularly African Americans, to jobs; the major remedy was to be opening up the suburbs to the disadvantaged. This early framing of the urban poverty problem as connected to urban-suburban disparities quickly became the prevailing wisdom. By the mid-90s, researchers were framing the problem in terms of the "geography of metropolitan opportunity", referring to the actual prospects that the opportunity structure (as governed by markets, institutions, and social systems) offers based on geography ${ }^{6}$. In another memorable construction, Rusk analogized the landscape of metropolitan opportunity to the game of basketball, prescribing a focus on the outside game as the way to solve the problems of the inside game 7 .

Members of the equity regionalist camp self-identify as advocates of social justice. The idea behind regional strategies for poverty is that they will allow for equality of opportunity and thus improve the life chances of the impoverished. Equity regionalists seek to maximize individual utility, seeing mobility as the means - in what Imbroscio calls the mode of "liberal expansionism ${ }^{8}$. The need to level the playing field creates an imperative for action; as a National Academy of Sciences committee on metropolitan governance framed it, "A lack of equal opportunity is thus in the most profound sense a 'moral' problem for Americans"'.

5. KaIn John F., “The spatial mismatch hypothesis: Three decades later”, in Housing Policy Debate, vol. 3, $\mathrm{n}^{\circ}$ 2, 1992, p. 371-460.

6. Galster George, Killen Sean, "Geography of Metropolitan Opportunity: A Reconnaissance and Conceptual Framework", in Housing Policy Debate, vol. 6, n 1, 1995, p. 7-43.

7. Rusk David, Inside Game/Outside Game: Winning Strategies for Saving Urban America, Washington, D.C., Brookings Institution Press, 1998.

8. Imbroscio David, "Shaming the Inside Game: A Critique of the Liberal Expansionist Approach to Addressing Urban Problems", in Urban Affairs Review, vol. 42, n 2, 2006, p. 224-248.

9. Governance and Opportunity in Metropolitan America, Altshuler Alan (ed.), Washington, D.C., National Academy Press, 1999, p. 18. 
Regional strategies to remedy unequal opportunity include changing the spatial distribution of population (for instance through creating new housing choices in the suburbs, moving inner-city residents to the suburbs, or transporting city residents to suburban jobs) or reducing tax or service disparities (typically either via tax base sharing or new regional governing strategies). The focus of these strategies is on sharing the resources or opportunities of the region's outer rings with its core, to create a more just spatial distribution.

Yet, a growing body of work on the "just city ${ }^{10 "}$ implies that equity regionalist strategies to address poverty may not address systemic injustices. Though remedying unequal opportunity is obviously important to regional equity, it may not be possible to satisfy common aspirations and respect human dignity through policy that attempts to construct an even landscape of metropolitan opportunity. Planners adopting liberal conceptions of justice embrace an abstract principle of equality at the expense of situated ethical judgment that appreciates individual circumstance ${ }^{11}$.

This paper examines the idea and practice of regional anti-poverty strategies in the light of different conceptions of social justice. We begin by describing four types of equity regionalist strategies: regional governing structures, fair share housing, tax base sharing, and dispersal and mobility policies. We then show how new regionalism finds its moral underpinnings in the work of Rawls ${ }^{12}$. We next examine alternative notions of social justice, in particular the ideas of capabilities, the need for affiliation, and the "right to the city" and urban life ${ }^{13}$. We conclude by discussing whether and

10. E. g., Fainstein Susan, "Planning and the Just City", New York City, Columbia University, 2006, Unpublished paper presented at Searching for the Just City Conference.

Fiscal Disparities: Tax Base Sharing in the Twin Cities Metropolitan Area, Metropolitan Council, 2008, www.metrocouncil.org/metroarea/FiscalDisparities/index. htm; Nussbaum Martha, Women and Human Development: The Capabilities Approach, New York, Cambridge University Press, 2000; SEN Amartya, Development as Freedom, New York, Anchor, 1999.

11. Camp bell Heather, "Just Planning: The Art of Situated Ethical Judgment", in Journal of Planning Education and Research, vol. 26, n 1, 2006, p. 92-106.

12. Rawls John, A Theory of Justice, Massaze, Belknap Press of Harvard University Press, 1971.

13. Writings on Cities, Lefèbvre Henri, Kofman Eleonore, Lebas Elizabeth (eds.), Cambridge (MA), Blackwell, 1996; Nussbaum Martha, Women and Human Development: The Capabilities Approach, op. cit.; SEN Amartya, Development as Freedom, op. cit. 
how the state and planners can intervene to produce a more just metro for those living in concentrated poverty neighborhoods.

\section{OVERVIEW OF REGIONAL STRATEGIES \\ AND THEIR OUTCOMES}

Throughout the twentieth century, regionalists advanced spatial strategies to improve regional efficiency and competitiveness, with notable examples from the 1929 Regional Plan of New York to the advent of regional councils of government (COGs) and metropolitan planning organizations (MPOs) in the 1960s and 1970s, to plans such as Envision Utah! in the 1990s. The push for equity regionalism emerged relatively late in the game, as awareness of urban-suburban disparities increased. Of the four strategies discussed in this article, most appeared by the mid-1970s. Regional government - an equity strategy to the extent to which it evens out service and fiscal disparities - was the first to appear, in the form of the COGs and MPOs, as well as ongoing government consolidations among cities and counties. Tax base sharing, which redistributes tax revenues among local governments in a metropolitan area, originated in the Twin Cities' 1971 Fiscal Disparities Act. Fair share housing programs (including inclusionary zoning), which require developers to provide low - or moderate-income housing units in exchange for development permission, were implemented by multiple states in the 1970s. Finally, though the 1970s saw some trials of dispersal and mobility programs, the federal government implemented larger-scale experiments in the 1990s.

\section{Regional government}

Regional governing strategies provide a variety of ways to equalize opportunity across a region, either by changing the spatial distribution of the population through land use planning and growth control or by reducing service disparities through governmental consolidation, special purpose districts, or state equalization aid. Although the latter two strategies are quite common, the others are much rarer ${ }^{14}$.

State or metropolitan land use planning can help create a more even landscape of opportunity in particular by requiring local governments to zone for more of the region's high-density housing (by ending exclusionary practices or assuming its fair share of regional housing need, as discussed

14. Governance and Opportunity in Metropolitan America, op. cit. 
further below). Though debate is ongoing on the effectiveness of land use planning or growth control as a regional equity strategy, it seems to be associated with increases in housing prices ${ }^{15}$. Perhaps the outcome would be different if regions incentivized affordability at the same time as encouraging density. Such was the format of the acclaimed Montgomery County inclusionary zoning program, which requires the provision of moderateincome dwelling units but has its county public housing agency purchase one-third of these units ${ }^{16}$.

Government consolidations typically unify the city and county governments (e.g., Miami-Dade County). There have been just 22 approved since 1921, perhaps in part because of the difficulty of gaining both city and suburban voter approval ${ }^{17}$. In theory, a single general-purpose regional government would eliminate both tax and service disparities by centralizing government taxing powers and service delivery. However, in practice, it may not actually succeed in remedying tax and service disparities. Individual cities often retain their taxing authority, undermining the idea of revenue sharing, and studies have shown that cities as well as consolidated metros consistently underserve their minority and low-income neighborhoods and/or dilute minority voices ${ }^{18}$. Special districts (e.g., for water or sewer services) function in much the same way, with their own taxing and service functions, but have rarely been evaluated in terms of their ability to remedy inequities ${ }^{19}$.

State and federal equalization aid, which take the form of either general revenue sharing grants or special grants (e.g., for education) from higher levels of government, helps to remedy fiscal disparities among cities. These generally reduce differences in per capita spending, but rarely actually equalize it, due to both the inequality in other sources of funding and the variation in need ${ }^{20}$.

15. Nelson Arthur, Pendall Rolf, Dawkins Casey J., J. KnaAp Gerrit, "The links between Growth Management and Housing Affordability: The Academic Evidence", in Growth Management and Affordable Housing: Do They Conflict?, Downs Anthony (ed.), Washington, D.C., Brookings Institution Press, 2004, p. 117-158.

16. Rusk David, Inside Game/Outside Game: Winning Strategies for Saving Urban America, op. cit.

17. Governance and Opportunity in Metropolitan America, op. cit.

18. Ibid.

19. Ibid.

20. Ibid. 


\section{Fair share housing}

Regional fair share housing strategies attempt to address inequities in the regional distribution of affordable housing, in order to shift more affordable housing provision to the outside game ${ }^{21}$. Typically, the approach is based on a formula for assigning affordable housing obligations to regional sub-areas, most frequently individual municipalities within a single metropolitan area. The formulae can take different forms, emphasizing a range of parameters that can be used to establish what a "fair" distribution of housing opportunities within a metro area should look like. Typical elements of fair share formulae are existing population in sub-areas, estimated population growth, and the (inverse of) relative availability of low-cost or subsidized housing.

The fair share approach was popular in the United States for a short period of time more than 30 years ago. In the early 1970s, shortly after passage of the Fair Housing Act, the U.S. Department of Housing and Urban Development supported the creation of fair share strategies in metro areas around the country. Regional authorities in a number of areas created programs aimed at producing a more equitable distribution of subsidized housing between cities and their suburban satellites. These efforts, and HUD's interest in supporting them, were short-lived. Probably the best of these programs, the Regional Housing Needs Assessment process in California, has survived largely due to the threat of litigation, but has compromised in its commitment to affordability ${ }^{22}$. In other places, the rapid decline in federal subsidies for low-cost housing has rendered fair share allocation systems irrelevant by making the development of affordable housing difficult in all communities. Further, the lack of political appetite for subsidized housing in the suburbs has been an insurmountable obstacle to implementation of fair share schemes ${ }^{23}$. In Minnesota's fair share housing program, a lack of funding, political will, and planner savvy meant

21. Bollens Scott, "In Through the Back Door: Social Equity and Regional Governance", op. cit.

22. Calavita Nico, Grimes Kenneth, Mallach Alan, "Inclusionary Housing in California and New Jersey: A Comparative Analysis", in Housing Policy Debate, vol. 8, n 1, 1997, p. 109-142.

23. Basolo Victoria, Hastings Dorian, "Obstacles to Regional Housing Solutions: A Comparison of Four Metropolitan Areas", in Journal of Urban Affairs, vol. 25, n 4, 2003, p. 449-472; Goetz Edward G., Clearing the Way: Deconcentrating the Poor in Urban America, Washington, D.C., Urban Institute Press, 2003; Goetz Edward G., Chapple Karen, Lukermann Barbara, "Enabling Exclusion: The Retreat from Regional Fair Share Housing in the Implementation of the Min- 
that just five acres of every 100 acres set aside for affordable housing in the program actually had new low - or moderate-income housing twenty years later ${ }^{24}$.

One of the few programs to endure was the court-ordered effort in New Jersey. A product of the Mt. Laurel I and Mt. Laurel II rulings, the state of New Jersey produced a system of regional fair share housing administered by the statewide Council on Affordable Housing. In place for more than 20 years, this program imposes an affirmative obligation on communities within urban regions to create affordable housing. Over 22,000 units of housing were subsidized in the first 10 years of the program ${ }^{25}$. The potential for the program to significantly alter the spatial distribution of low-cost housing is seriously limited by the program provision that allows municipalities to purchase compliance credits from each other. Under these so-called Regional Contribution Agreements (RCAs), a community that does not wish to actually build affordable housing can transfer up to $50 \%$ of its affordable housing obligation to another community by paying the second community. The receiving community, typically larger, lower-income, and more racially diverse communities, take, in the aggregate, millions of dollars from higher-income, whiter communities, to finance affordable housing efforts.

The scale of the New Jersey approach is sufficient to produce a sizable number of affordable housing units in communities that likely would not have built them otherwise. In this respect, the program is producing a more equitable distribution of housing opportunities within the state's urban regions (notwithstanding the limiting effects of RCAs). In terms of facilitating a movement of families out of concentrated poverty, or out of racially segregated areas, the program has had a negligible effect. Most units built in the suburban areas of metro regions are occupied by families who already lived in the suburbs. Only $6.8 \%$ of units are occupied by AfricanAmerican families who moved out of a central city and into a suburb. When movement in the other direction is accounted for (i.e., the movement of African-American families out of the suburbs and into a Mt. Laurel unit built within a central city) the net movement of such families into

nesota Land Use Planning Act", Journal of Planning Education and Research, vol. 22, $\mathrm{n}^{\circ} 3,2003$, p. 213-25.

24. Ibid.

25. Wish Naomi B., Eisdorfer Stephen, "The Impact of Mount Laurel Initiatives: An Analysis of the Characteristics of Applicants and Occupants", in Seton Hall Law Review, vol. 27, 1997, p. 1268-1337. 
desegregated suburban areas accounts for less than two percent of all Mt. Laurel units ${ }^{26}$.

\section{Tax base sharing}

As with fair share housing, tax base sharing is a program that receives a great deal of attention from equity regionalists, but exists in only a few places. Summer identified nine urban areas with a general tax base sharing effort $^{27}$. The most well-known example is in the Minneapolis-Saint Paul metropolitan area. Since 1971, local governments in that region have been sharing a portion of the commercial/industrial (CI) tax base and reallocating those resources within the region. The program applies to a portion of the increment in CI tax base generated in all municipalities within the region. Specifically, $40 \%$ of the increment in CI property tax revenues for each municipality is put into a regional pool. The allocation of revenues from that pool is made according to a formula. If a jurisdiction's allocation from the pool is greater than its contribution, it is a net recipient under the law. In many cases, recipients are on the inside while donors come from the periphery of the region.

By 2003, the program's pool of tax resources accounted for 10 percent of the entire metro-wide tax base from all sources, and totaled 345.8 million dollars $^{28}$. The Metropolitan Council of the Twin Cities estimates that the program reduces disparities in CI tax base from what would be a 12 to 1 per capita ratio to a 4 to $1 \mathrm{ratio}^{29}$. However, since the formula requires cities that have a rich commercial property base to pay into the pool even if they also have a high poverty population, tax base sharing can be inequitable; e.g., Minneapolis has occasionally been a donor city, as has Dayton ${ }^{30}$.

26. Ibid.

27. Summer A. A., "Regionalization efforts between big cities and their suburbs: Rhetoric and reality", in Urban-Suburban Interdependencies, GreEsteIn Rosalind, Wiewel Wim (eds.), Cambridge, MA, Lincoln Institute of Land Policy, 2000.

28. Hinze Steve, Baker Karen, Minnesota's Fiscal Disparities Programs: Twin Cities Metropolitan Area and Iron Range, Saint Paul, MN, Minnesota House Research Department, 2005, www.house.leg.state.mn.us/hrd/pubs/fiscaldis.pdf.

29. Fiscal Disparities: Tax Base Sharing in the Twin Cities Metropolitan Area, op. cit.

30. Governance and Opportunity in Metropolitan America, op. cit. 


\section{Dispersal and mobility}

Dispersal policy is reflected in three major policy initiatives, the Gautreaux program, Moving To Opportunity, and the HOPE VI program. The Gautreaux consent decree - which was followed by at least eleven others forced the Chicago Housing Authority develop a metropolitan-wide "mobility program" to partially compensate for its discriminatory practice of placing public housing in predominantly African-American or racially changing areas ${ }^{31}$. Over a twenty-year period, over 7,100 families were relocated from virtually all-black urban areas to middle-income, overwhelmingly white areas in Chicago and its suburbs ${ }^{32}$.

Inspired by the success of Gautreaux and its tenant-based mobility structure, Congress authorized the Moving to Opportunity (MTO) demonstration program in 1992 in the cities of Baltimore, Boston, Chicago, Los Angeles, and New York City. Participants in an experimental group (which was paired with two control groups) moved from very high poverty to lowpoverty neighborhoods. MTO, then, was an early attempt to assess whether low-poverty areas translated into improved life chances for low-income households.

As with other deconcentration programs, HOPE VI, authorized in 1992, involved the relocation of residents of distressed public housing to different neighborhoods. HOPE VI provides funds to local housing authorities for the redevelopment of severely distressed public housing projects. HOPE VI projects typically involve displacement and relocation of public housing residents, and demolition to make way for newly constructed, mixed-income developments. It differs from Gautreaux and MTO in its much larger scale, since hundreds of public housing authorities nationwide have implemented it, and larger scope, involving both demolition and construction.

Program outcomes have generally been mixed, with voluntary programs like MTO faring slightly better than involuntary like HOPE VI. Most prominently, no dispersal policy has had a demonstrable positive effect on economic opportunity, as measured by employment, earnings, or income of individuals. In the Gautreaux program in Chicago, the outcome for families who moved to the suburbs was no change in employment or wages.

31. Goetz Edward G., Clearing the Way: Deconcentrating the Poor in Urban America, op. cit.

32. Rubinowitz Leonard S., Rosenbaum James E., Crossing the Class and Color Lines: From Public Housing to White Suburbia, Chicago, University of Chicago Press, 2000. 
This failure is repeated for individuals in the MTO program, every HOPE VI study thus far completed, and even HUD's Welfare to Work Voucher Program ${ }^{33}$. Dispersal may actually increase economic insecurity: relocatees lack money for food and rent and lack residential stability ${ }^{34}$.

Although initial findings from the Gautreaux experiment suggested that relocating to the suburbs would have a positive outcome on schooling, subsequent studies have tempered those results, and effects on achievement overall seem to be small ${ }^{35}$. The majority of studies also show little in the way of a health benefit for low-income individuals $s^{36}$. The move itself seems to have negative impacts on those forced to relocate (e.g., in HOPE VI), because of their attachment to place ${ }^{37}$.

33. Clampet-Lundquist Susan, "Moving Over or Moving Up? Short-Term Gains and Losses for Relocated HOPE VI Families", in Cityscape, vol. 7, $\mathrm{n}^{\circ}$ 1, 2004, p. 57-80; Goering John, Feings Judith D., Choosing a Better life: Evaluating the Moving to Opportunity Social Experiment, Washington, D.C., Urban Institute Press, 2003; Rubinowitz Leonard S., Rosenbaum James E., Crossing the Class and Color Lines: From Public Housing to White Suburbia, Chicago, Chicago, University of Chicago Press, 2000.

34. Buron Larry, Popkin Susan J., Levy Diane, Harris Laura E., Khadduri Jill, The HOPE VI Resident Tracking Study: A Snapshot of the Current Living Situation of Original Residents from Eight Sites, Washington (D.C.), The Urban Institute, 2002; Clampet-Lundquist Susan, "Moving Over or Moving Up? Short-Term Gains and Losses for Relocated HOPE VI Families", op. cit.; Gibson Karen, "The Relocation of the Columbia Villa Community: Views from Residents", in Journal of Planning Education and Research, vol. 27, n 1, 2007, p. 5-19; Popkin Susan J., "The HOPE VI Program: What Has Happened to the Residents?", in Where are Poor People to Live: Transforming Public Housing Communities (Cities and Contemporary Society), BeNNett Larry, Smith Janet L., Wright Patricia A. (eds.), Armonk, New York, M.E. Sharpe, 2006; Rosenbaum James E., Popkin Susan J., "Employment and earnings of low-income blacks who move to middle-class suburbs", in The Urban Underclass, Jencks Christopher, Peterson Paul E. (eds.), Washington, D.C., The Brookings Institute, 1991.

35. Gallagher Megan, Bajaj Beata, "Moving on: Benefits and challenges of HOPE VI for children", in Metropolitan Housing and Communities, $\mathrm{n}^{\circ} 4$ ("Urban Institute Policy Brief”), June 2007, p. 1-9; Popkin Susan J., “The HOPE VI Program: What Has Happened to the Residents?", op. cit.

36. Gallagher Megan, Bajaj Beata, "Moving on: Benefits and challenges of HOPE VI for children”, op. cit; Popkin Susan J., "The HOPE VI Program: What Has Happened to the Residents?", op. cit.

37. Kleit Rachel G., Manzo Lynne C., "To move or not to move: Relationships to place and relocation choices in HOPE VI", in Housing Policy Debate, vol. 17, $\mathrm{n}^{\circ} 2$, 2006, p. 271-308; Gibson Karen, "The Relocation of the Columbia Villa Community: Views from Residents", op. cit. 
Perhaps most important, relocation does not seem to stimulate social interaction between higher - and lower-income residents ${ }^{38}$. Recent work on diversity ${ }^{39}$ supports this finding: communities may be coping with their diversity by avoiding high levels of interaction.

On the plus side, studies consistently show that families that move out of neighborhoods of concentrated poverty report benefits of increased sense of safet ${ }^{40}$. Moreover, improvements in housing and neighborhood characteristics consistently occur ${ }^{41}$.

Another major approach to make jobs more accessible is to connect jobseekers to opportunities throughout the metropolitan region through transportation. Most funding to link low-income urban residents to suburban jobs (for instance, the Jobs Access and Reverse Commute program) has supported reverse commuting via transit or vanpooling. Yet, historically, such initiatives have had little success, particularly in terms of reducing inner city unemployment, though they may help those who are already employed ${ }^{42}$.

Likewise, the recent Bridges to Work experiment, which provided job placement and transportation services to help urban low-skilled workers access suburban jobs in five regions, concluded that it was not an effective solution, since the program did not increase employment or earnings

38. Clampet-Lundquist Susan, "Moving Over or Moving Up? Short-Term Gains and Losses for Relocated HOPE VI Families", op. cit.; Goetz Edward G., Clearing the Way: Deconcentrating the Poor in Urban America, op. cit.

39. Putnam Robert, "E Pluribus Unum: Diversity and Community in the TwentyFirst Century - The 2006 Johan Skytte Prize Lecture", in Scandinavian Political Studies, vol. 30, $\mathrm{n}^{\circ}$ 2, 2007, p. 137-174.

40. See Buron Larry et al., The HOPE VI Resident Tracking Study ..., op. cit.; Gibson Karen, "The Relocation of the Columbia Villa Community: Views from Residents", op. cit.; Goetz Edward G., Clearing the Way: Deconcentrating the Poor in Urban America, op. cit.

41. Buron Larry, et al., The HOPE VI Resident Tracking Study..., op. cit.; Kleit Rachel G., Manzo Lynne C., "To move or not to move: Relationships to place and relocation choices in HOPE VI", op. cit.; Gallagher Megan, BajAJ Beata, "Moving on: Benefits and challenges of HOPE VI for children", op. cit.; Gibson Karen, "The Relocation of the Columbia Villa Community: Views from Residents", op. cit.; Goetz Edward G., Clearing the Way: Deconcentrating the Poor in Urban America, op. cit.; Popkin Susan J., "The HOPE VI Program: What Has Happened to the Residents?", op. cit.

42. O’Regan Katherine M., Quigley John M., "Spatial Isolation and Welfare Recipients: What do We Know?", in Berkeley Program on Housing and Urban Policy, Working Papers: Paper W99-003, 1999. 
(compared to a control group $)^{43}$. Perhaps because the labor market was relatively tight when the program was implemented, turnover at the suburban jobs was high; given the choice between the low-wage, low-skill jobs in the suburbs or close to home in the city, jobseekers chose the latter. The findings indicated that workforce development, particularly recruitment and job-readiness, is the major policy challenge in improving the employment chances of the disadvantaged, and in any case workers will not take on long reverse commutes if they cannot realize substantially higher wages in return ${ }^{44}$.

\section{Key CONCEPTS OF JUSTiCE \\ UNDERLYING THE NEW REGIONALISM}

The argument that we should create an even landscape of opportunity through strategies that change the spatial distribution of the population or remedy fiscal disparities finds much of its moral underpinnings in the work of John Rawls ${ }^{45}$. There are three components of Rawls' theory of justice that are relevant to the equity regionalist argument: the "difference principle", the idea of "primary goods", and the "original position."

\section{The Difference Principle}

In his second principle of justice (the difference principle), Rawls ${ }^{46}$ argues that:

Social and economic inequalities are to be arranged so that they are both (a) to the greatest expected benefit of the least advantaged and (b) attached to offices and positions open to all under conditions of fair equality of opportunity.

The idea of equality of opportunity is not just that "offices and positions" are open to all, but that all have the opportunity to acquire the skills necessary in order to achieve in a meritocracy. Rawls acknowledges that social

43. Roder Anne, SCrivner Scott, Seeking a sustainable journey to work: Findings from the National Bridges to Work Demonstration, Philadelphia, Public/Private Ventures, 2005.

44. A growing alternative to reverse commuting via transit is car ownership for low-income households: over 150 nonprofit car ownership or loan programs have emerged around the country, but they have not been systematically evaluated and may be most appropriate for low-density or rural areas.

45. Rawls John, A Theory of Justice, op. cit.

46. Ibid., p. 72. 
and economic inequality is pervasive and does not suggest that the distribution of wealth and income should be equal, but that it should be to everyone's advantage. In remedying inequalities, maintaining some unequal distribution is justifiable as long as it is to the benefit of all. In order to be just, the more fortunate can benefit disproportionately so long as the condition of the least well-off improves relative to their previous state.

Like Rawls, the equity regionalist argument starts from the position that the distribution of opportunities and resources across metropolitan areas is unjust. As has been well documented elsewhere ${ }^{47}$, economic restructuring reinforced by public policy exacerbated existing inequalities within metropolitan areas by the end of the 20th century, with increasing concentrations of poverty in the inner city and affluence in the suburbs. Equity regionalists seek to establish a more just distribution by breaking up pockets of poverty, creating more housing choice in the suburbs, revitalizing the old inner city neighborhoods with an influx of upper-income residents, and equalizing fiscal resources and thus service expenditures. Equity regionalists are not so naïve as to think this will fully remedy inequality, but they do expect the change to improve the condition of the least well-off by putting them in an environment rich with resources and opportunities; at a minimum, fair governance coupled with less isolation from the mainstream should level the playing field. If opportunity depends on the ability of individuals to acquire skills to succeed in the meritocracy, then living in the suburbs is key.

Has equity regionalism succeeded in providing more equality of opportunity, with the least advantaged all experiencing some improvement? The overview of equity regionalist strategies, above, suggests a mixed, but mostly failed record. Of regional governing strategies, the most promising is probably state equalization aid, which at least improves the resources available to the least advantaged. However, government consolidations do not have a strong record in addressing equity issues, land use planning that incorporates measures for housing affordability (including fair share housing) has been sparingly implemented, and there are also just a few instances of tax-base sharing.

The impact of the new wave of dispersal and mobility policies on equality of opportunity is even more questionable. In the best case (the MTO program, rather than HOPE VI), dispersal policies have helped families to

47. E. g., Dreier Peter, Mollenkopf John, Swanstrom Todd, Place Matters: Metropolitics for the Twenty-First Century, Second Edition, Lawrence, University Press of Kansas, 2005. 
move to residential neighborhoods with lower levels of poverty. But even so, direct benefits to the families are limited. Families feel safer and they report some inconsistent improvements in mental health. But there are conspicuously no benefits in employment, income, welfare dependency, or physical health. Further, many of the families suffer significant interruptions in their social networking. Likewise, mobility programs, particularly reverse commuting programs, have failed to improve access to jobs and thus do not have an impact on equality of opportunity. In other words, dispersal and mobility policies are failing even to meet the Rawlsian condition of benefit to all, since life chances are not improving in the new neighborhoods relative to the former neighborhoods.

Justifiable from the Rawlsian perspective is the fact that the well-off may benefit even more than the disadvantaged. Though almost all equity regionalist strategies involve redistribution from the wealthy to the poor, dispersal policy offers significant, even disproportionate, benefits to the affluent. In particular, HOPE VI, which has replaced low-income housing with moderate-income and market-rate housing in the urban core, has helped more affluent residents not only move near downtown, but recapture land value in choice neighborhoods nearby.

\section{Primary Goods}

In order to realize opportunity, individuals need equality in "primary goods." These are defined as the prerequisites, both social and natural, for rational individuals to achieve their life plans. Social goods include rights, liberties, and opportunities, which confer the capacity to realize goals, but also income and wealth. Natural goods include health, intelligence, and imagination. According to Rawls, these add up to self-respect: a sense of one's own value and confidence in one's ability to carry out one's life plan.

From the equity regionalist perspective, the suburbs offer more equality in primary goods than cities do. The suburbs not only improve access to opportunity but also offer a higher quality of life ${ }^{48}$. In the city, the persistent and unsafe ghetto culture, a.k.a. the culture of poverty, reflects the lack of self-respect and devaluing of human life, particularly among low-income minorities ${ }^{49}$. But in the suburbs, the quality of public services and schools is better, neighborhoods are safer and friendlier, and the sense of community

48. Ibid.

49. Wilson William J., The Truly Disadvantaged: The Inner City, the Underclass, and Public Policy, Chicago, The University of Chicago Press, 1987. 
is greater. By implication, ghetto culture will not take hold in the suburbs and thus will not hinder the acquisition of primary goods there.

This assumes, of course, that the suburbs do offer enhanced opportunities to acquire skills: that suburban schools are of high quality, jobs are plentiful and accessible, and social systems and networks are inclusive. In practice, however, the failure in particular of dispersal and mobility programs challenges this assumption. Though the new neighborhoods may offer relatively more primary goods, this masks the fact that the families are by and large relocating to other high-poverty, racially segregated neighborhoods. And often, the suburbs do not improve primary goods. For instance, relocatees typically experience difficulty rebuilding social networks, and perhaps because of this, are unable to improve in terms of economic opportunity. Likewise, they do not experience improved health outcomes, perhaps because of losing access to health services and institutions once located outside the urban core.

In the case of mobility programs, such as the Bridges to Work program, reverse commuters may actually end up in weaker labor markets than in the central city. In the case of tax base sharing, equality in primary goods may not result because some cities are more expensive to service than others. Given cities' different service environments, equal inputs (tax revenues) do not necessarily lead to equal outcomes.

\section{The Original Position}

Another component of Rawls' argument that is relevant to the new regionalist standpoint is the "original position", the idea that everyone should decide principles of justice from behind a "veil of ignorance", a lack of knowledge about their own position in society. In order to further justice, individuals should devise strategies without knowing how s/he will benefit. If we start from this original position, we will maximize the benefit to the least well-off. In other words, the pursuit of justice should be ahistorical.

The equity regionalist argument blames the failed policies of the past, in particular the construction of public housing through the 1950s, the community economic development policies of the 1960s and 1970s, and government-led suburbanization for regional inequity. Instead, it proposes a set of new policies to even out resources and opportunities across the region. Interestingly, these policies do not grow out of an understanding of why past policies have failed (e.g., the lack of funding to cover public housing maintenance, the lack of funding for the War on Poverty, and the inability of municipalities to zone for and fund affordable housing). Rather, 
they in essence start from behind the "veil of ignorance": they propose as a solution altogether different governance structures (from the market provision of affordable housing for voucher holders, to government mandates to meet affordable housing need, to new ways of distributing services and revenues across the metro). In other words, the veil of ignorance extends to the problem definition: the underlying assumption is that the problem is not the failure of the market and suburban municipalities to provide affordable housing opportunities, but the inability of individuals to exit public housing stock.

Further, it is hard to argue that these policies, particularly dispersal, are constructed without stakeholders knowing how they will benefit. There is clear benefit to the inner city growth machine in removing low-income residents - yet there is no critical examination of such benefit.

\section{EQUITY REGIONALISM}

\section{AND ALTERNATIVE CONCEPTIONS OF JUSTICE}

Although the idea of equality of opportunity underlies much of equity regionalist policy, there are other ways to examine the issues of justice and opportunity in the inner city. The capabilities approach ${ }^{50}$ shifts our focus to what inner-city residents are able to do or be, instead of how much they can achieve in purely economic terms. Related to this is the idea that needs differ among groups, so the Rawlsian set of primary goods may not apply uniformly to all and equal starting points may not mean equal outcomes ${ }^{51}$. Another line of argument lies in the concept of a "right to the city ${ }^{52}$ ", which includes the right to urban life and its centrality, vitality, and visibility ${ }^{53}$.

50. Sen Amartya, Development as Freedom, op. cit.; Nussbaum Martha, Women and Human Development: The Capabilities Approach, op. cit.

51. Fainstein Susan, "Planning and the Just City", op cit.; Harvey David, Social Justice and the City, Baltimore, The Johns Hopkins Press, 1973; Nussbaum Martha, Women and Human Development: The Capabilities Approach, op. cit.

52. Writings on Cities, op. cit.

53. Fainstein Susan, "Planning and the Just City", op cit.; Mitchell Don, The Right to the City: Social Justice and the Fight for Public Space, New York, Guilford Press, 2003. 


\section{Capabilities}

The capabilities approach ${ }^{54}$ suggests that instead of thinking about distribution in terms of the resources people are able to access, we should examine what their environmental context allows them to do or be. Capabilities encompass many of Rawls' social and natural goods, but also include the pursuit of "affiliation": "being able to live with and toward others, to recognize and show concern for other human beings, to engage in various forms of social interaction; to be able to imagine the situation of another and to have compassion for that situation; to have the capability for both justice and friendship ${ }^{55}$ ".

The idea of affiliation acknowledges the use value of urban space, which Lefèbvre incorporates into his idea of city as "oeuvre", or a collective project in which all of its citizens participate. The tension between use value and exchange value fosters battles for urban land: "This city is itself 'oeuvre', a feature which contrasts with the irreversible tendency towards money and commerce, towards exchange and products. Indeed the oeuvre is use value and the product is exchange value ${ }^{56}$. . Residents have a right to the oeuvre, since it allows them to meet their social needs, which "include the need for security and opening, the need for certainty and adventure, that of organization of work and of play, the needs or the predictable and the unpredictable, of similarity and difference, of isolation and encounter, exchange and investments, of independence (even solitude) and communication, of immediate and long-term prospects ${ }^{57}$.

As Fainstein ${ }^{58}$ and other critics point out, the Rawlsian focus on equality among individuals sidesteps these issues of social affiliation and needs. Omitting the collectivity from the discussion means that certain types of goods - particularly those associated with social affiliation - are not considered important: "The starting point of individual liberty also avoids questions that bear on the character of collective goods - e.g. a high-quality built environment - if they are not necessary for the development of capabilities or remedying inequality ${ }^{59}$.

54. Sen Amartya, Development as Freedom, op. cit.

55. Nussbaum Martha, Women and Human Development: The Capabilities Approach, op. cit., p. 79.

56. Writings on Cities, op. cit., p. 66.

57. Ibid., p. 147.

58. Fainstein Susan, "Planning and the Just City", op cit.

59. Ibid., p 17. 
Thus, it is perhaps not surprising that some equity regionalist strategies - in particular, dispersal and mobility strategies - have met with mixed success. If dispersal has not improved access to natural goods, such as health, and social goods, such as economic opportunity, then the move to the suburbs may actually hinder the development of capabilities. If the development of capabilities rests in part on meeting the need for social affiliation, then the disruption of social networks that occurs when the spatial distribution of the population changes may likewise affect capabilities negatively.

The concept of the "oeuvre" sheds light on why mobility strategies have not succeeded in helping city residents access suburban jobs. Strategies that purely promote physical access to jobs ignore the intricate social system through which people find jobs - let alone the workforce development system which, at its best, provides a valuable channel for information about the labor market ${ }^{60}$.

\section{Differing needs}

We turn next to the issue of whether and how needs for primary goods differ among groups. From a Rawlsian perspective on how to create equality of opportunity, policymakers would first need to measure how residents of concentrated poverty neighborhoods are faring in terms of resources. This apparently assumes a homogeneous public with similar levels of needs ${ }^{61}$. Yet, as Harvey points out, different groups have different elasticities in use of resources, so equality of opportunity depends on social context. For instance, if people lack "cultural motivation" to use parks, developing such facilities for them will not lead to a more just income distribution $^{62}$. Housing opportunity is another of Harvey's examples ${ }^{63}$ : "Lowincome groups, for example often identify very closely with their housing

60. Chapple Karen, "Overcoming Mismatch: Beyond Dispersal, Mobility, and Development Strategies", in Journal of the American Planning Association, vol. 72, $\mathrm{n}^{\circ} 3,2006$, p. 322-336.

61. Young Iris M., Inclusion and Democracy, New York, Oxford University Press, 2000.

62. Harvey David, Social Justice and the City, Baltimore, Johns Hopkins University Press, 1973.

63. Also see Gans Herbert, "The Failure of Urban Renewal: A Critique and Some Proposals", in Gans Herbert, People and Plans: Essays on Urban Problems and Solutions, New York, Basic Books, 1968, and Fullilove Mindy, Root Shock: How tearing up city neighborhoods hurt America and what we can do about it, New York, Ballantine Books, 2004. 
environment and the psychological cost of moving is to them far greater than it is to the mobile upper middle class."

Suppose that metropolitan areas were reorganized so that each individual had the same level of resources and opportunities, or at least a threshold level: social services, amenities, education and work opportunities are distributed equally across the region, in a utopian spatial allocation. Yet, utility differs: "giving resources to people does not always bring differently situated people up to the same level of capability to function ${ }^{64 "}$. Coming from different backgrounds, some may lack the ability to use resources in order to function better. In fact, Nussbaum argues that assuming resources benefit all equally "doesn't sufficiently respect the struggle of each and every individual for flourishing ${ }^{65}$ ".

In a context of differing needs, a metropolitan landscape of equal opportunity may mean little. A few examples suffice to illustrate this point. Housing choice vouchers will disproportionately benefit those with the mobility to assess housing opportunity throughout a region, as well as those without special housing needs - and will not necessarily meet the needs of those who are attached to their neighborhood and do not wish to move. Having jobs in close proximity means little without the network resources to get hired ${ }^{66}$. Tax-base sharing may create more equality of resources, but the disadvantaged may be less able to convert resources into opportunity, so that equality of opportunity, or of primary goods, may never result in equal outcomes. In contrast, the capabilities approach looks at what it would actually take to realize a life plan, which may entail more resources, social supports, and/or other assistance.

\section{The right to the city}

Another approach to social justice is the "right to the city ${ }^{67}$ ", which encompasses the ideas of diversity, amenity, and visibility. Fostering diversity is key to justice because it helps us imagine alternative futures and life plans. The city makes possible encounters with people who are different,

64. Nussbaum Martha, Women and Human Development: The Capabilities Approach, op. cit., p. 99.

65. Ibid., p. 69.

66. Chapple Karen, "Overcoming Mismatch: Beyond Dispersal, Mobility, and Development Strategies", op. cit.

67. Writings on Cities, op. cit. 
which in turn enriches experience. Thus the just city "ought to provide spaces in which valuably different forms of human activity can flourish ${ }^{68}$ ".

For the disadvantaged, being seen is just as important as seeing others. For Lefèbvre, the right to the city is essentially the right to inhabit, or the right of individuals and groups to shape the conditions of their existence in space. With the right to inhabit, oppressed groups can stay visible in the public eye. Possessing this "space for representation" helps give groups legitimacy in their struggles ${ }^{69}$.

As inner cities revitalize - and as public housing becomes mixed-income development - affluent newcomers squeeze out the disadvantaged. This threatens urban diversity and even the visibility of the least well-off. It also suggests another right: the right to enjoy "renewed centrality ${ }^{70 ": ~ " T h e ~ r i g h t ~}$ to the city ought to refer to more than mere inclusion - it needs to encompass access to an appealing city ${ }^{71}$.

The spatial fix offered by dispersal and mobility strategies conflicts directly with the right to the city. Vouchered out of downtown public housing, the poor lose their centrality, visibility, and access to diversity. Commuting out to jobs in the suburbs, jobseekers lose their connections to the urban economy. Even tax base sharing does not facilitate the right to urban life, since it essentially subsidizes municipalities to keep their poor in place.

\section{ConClusion:}

DoES EQUiTY REgIONALISM CREATE A JUST METRO?

In the aftermath of Hurricane Katrina, some 160 academics, led by Xavier de Souza Briggs and William Julius Wilson, suggested in a petition to Congress that there would be a silver lining as New Orleans residents would be able to "move to opportunity." In stinging rebuttals, critics argued that policymakers and researchers supporting dispersal policies are imposing their own values and norms on the poor, and aim to make poverty invisible rather than address its causes ${ }^{72}$. By two years later, research had shown that

68. Nussbaum Martha, Women and Human Development: The Capabilities Approach, op. cit., p. 60.

69. Mitchell Don, The Right to the City: Social Justice and the Fight for Public Space, op. cit., p. 33.

70. Writings on Cities, op. cit., p. 179.

71. Fainstein Susan, "Planning and the Just City", op cit., p. 18.

72. Imbroscio David, "Shaming the Inside Game: A Critique of the Liberal Expansionist Approach to Addressing Urban Problems”, op. cit.; Reed Adolph, Steinberg 
the relocatees were faring worse than those who returned to New Orleans, regardless of whether they had moved to a stronger regional economy $y^{73}$. Perhaps opportunity is not enough to solve poverty.

Casting justice in terms of equality of opportunity alone means neglecting the non-economic aspects of life - capabilities, social needs, urban life and vitality. Changing the spatial distribution of the population or remedying fiscal or service disparities may create a more optimal and equitable spatial allocation, but in some ways it fails to acknowledge basic human aspirations to live in security, in community, or in a revitalized core. In the case of regionalist dispersal programs, the attempt to achieve greater equality has even destroyed human dignity, in an uncanny replay of the urban renewal era ${ }^{74}$. It's not that opportunity does not matter, but rather that these spatial fixes are dually flawed: they fail to acknowledge the strengths of urban life, and they deflect attention from the real problem, lack of federal initiatives and funding to address issues of poverty, inequality, and insecurity.

The psychological literature on choice helps explain why pursuing equality of opportunity alone may not be the most just approach. Surveys have long shown that people strongly prefer stability to opportunity, given a choice between the status quo and uncertain future earnings ${ }^{75}$. The lower the income, the more choice is associated with fear, doubt, and difficulty: "While the upper and middle classes define freedom as choice, workingclass Americans emphasize freedom from instability

How is it that discussion of these policies continues, despite their shortcomings in addressing social equity? Arguably, they help build coalitions between the left and the right. Policies from dispersal to tax base sharing allow leftists to blame place rather than individuals - yet without blaming

Stephen, "Liberal bad faith in the wake of Hurricane Katrina", in Black Commentator, $\mathrm{n}^{\circ}$ 182, 2006, www.blackcommentator.com/182/182_cover_liberals_katrina_pf.html.

73. VIgdor Jacob L., "The Katrina Effect: Was There a Bright Side to the Evacuation of Greater New Orleans?", in The B.E. Journal of Economic Analysis \& Policy, vol. 7, $\mathrm{n}^{\circ}$ 1, art. 64, 2007.

74. Goetz Edward G., Clearing the Way: Deconcentrating the Poor in Urban America, op. cit.

75. Hacker Jacob S., The Great Risk Shift: The New Economic Insecurity and the Decline of the American Dream, New York, Oxford University Press, 2008.

76. Schwartz Barry, Markus Hazel R., Snibbe Alana C., "Is Freedom Just Another Word for Many Things to Buy?", in The New York Times, February 26, 2006. 
capitalism itself. Thus the left (as led by Loïc Wacquant ${ }^{77}$ ) remains enamored of the idea of an advanced marginality embedded in space, despite the rising deconcentration of the poor and their new exploitation in the era of Wal-Martization ${ }^{78}$. On the right, regionalist approaches gain support because they shift our gaze away from the defunding of anti-poverty and public housing programs, offering a set of solutions with low government cost (many of which also increase property values).

In some arenas, a new bottom-up equity regionalism is upending these old top-down approaches. Though not explicitly inspired by alternative conceptions of justice, many are advocating approaches that build on basic human aspirations and needs, rather than get implemented in spite of them because of an undue focus on ends rather than means. A regional equity movement, or "social movement regionalism", is building coalitions for economic justice, with considerable success in mobilizing constituencies at a regional scale for causes from living wages to community benefits $^{79}$. Also emerging are informal regional governance strategies employed by networks of public, private, and civic actors. In particular, communitybased organizations are using networks to exert power at the regional, state, and federal levels, in a process of multi-level governance ${ }^{80}$. Finally, a string of community economic development successes has led some to argue that Rusk $^{81}$ and others proclaimed the death of the inside game too soon.

77. Wacquant Loïc, Urban Outcasts: A Comparative Sociology of Advanced Marginality, Cambridge (UK), Polity, 2007.

78. Marcuse Peter, "Putting space in its place: Reassessing the spatiality of the ghetto and advanced marginality", in City, vol. 11, n 3, 2007, p. 378-383.

79. Pastor Manuel, Benner Chris, Matsuoka Martha, This Could Be the Start of Something Big: Regional Equity Organizing and the Future of Metropolitan America, Ithaca, NY, Cornell University Press, 2009.

80. Swanstrom Todd, Banks Brian, "Going Regional: Community-based Regionalism, Transportation, and Local Hiring Agreements", in Berkeley Institute of Urban and Regional Development, Working Papers: Working Paper 2007-17, 2007; Weir Margaret, Rongerude Jane, "Multi-Level Power and Progressive Regionalism", in Berkeley Institute of Urban and Regional Development, Working Papers: Working Paper 2007-15, 2007.

81. Rusk David, Inside Game/Outside Game: Winning Strategies for Saving Urban America, op. cit. 
Though the "poor in a loomp" may well be bad, using a spatial fix to destroy or move the loomp may not be the solution.

Karen CHAPple College of Environmental Design, University of California, Berkeley

Edward G. Goetz Humphrey School of Public Affairs, University of Minnesota 



\title{
L'immobilité, facteur d'injustice spatiale?
}

\author{
LA MOBILITÉ COMME VALEUR MONTANTE \\ ET COMME VECTEUR D'INJUSTICE SPATIALE
}

Depuis quelques années, la littérature sur le développement de la mobilité abonde. De nombreuses recherches montrent l'accroissement de la mobilité sous toutes ses formes ${ }^{1}$. Ils analysent les effets sociaux et spatiaux de cet accroissement du point de vue de l'individualisation des pratiques et de la multiplication des choix individuels ${ }^{2}$. Le succès de la thématique de la mobilité dépasse d'ailleurs largement le champ urbain puisque Boltanski et Chiapello ${ }^{3}$ montrent que la mobilité est l'une des valeurs et normes centrales du nouvel esprit du capitalisme. La capacité à se connecter à un univers réticulaire constitue dès lors une ressource de plus en plus décisive et l'individu est évalué sur sa faculté à se déplacer et à s'adapter. Cette montée de la mobilité comme exigence et comme valeur s'inscrit dans un processus large d'individuation qui n'est certes pas nouveau mais qui tend à s'accélérer dans la société post-industrielle et en devient même l'une des caractéristiques.

1. Urry, John, Sociology Beyond Societies. Mobilities for the Twenty-First Century, Londres, Routledge, 2000; LÉvy Jacques, "Les nouveaux espaces de la mobilité ", in Les Territoires de la mobilité, Bonnet Michel, Desjeux Dominique (dir.), Paris, PUF, 2000, p. 155-170.; Bourdin Alain, «Les mobilités et le programme de la sociologie ", in Cahiers Internationaux de Sociologie, vol. 118, 2005, p. 5-21.

2. Rémy Jean, "Mobilités et ancrages: vers une autre définition de la ville », in Mobilités et ancrages. Vers un nouveau mode de spatialisation?, Hirschorn Monique, Berthelot Jean-Michel (dir.), Paris, L'Harmattan, 1996; Ascher François, "Les sens du mouvement: modernités et mobilités ", in Les Sens du mouvement, Allemand Sylvain, Ascher François, Lévy Jacques, (dir.), Paris, Belin, 2004.

3. Boltanski Luc, Chiapello Ève, Le Nouvel Esprit du capitalisme, Paris, Gallimard, 1999. 
Cependant l'accès à la mobilité est différencié selon les individus et en particulier selon les groupes sociaux et les niveaux de revenus. Cet accès différencié tend à créer de nouvelles formes d'injustice spatiale. Ainsi, on constate des inégalités très importantes entre les pratiques de mobilité des ménages "pauvres ${ }^{4}$ » et des ménages aisés ${ }^{5}$. Possédant une plus grande faculté de délocalisation, les groupes dominants disposent de réseaux sociaux qui ne sont pas uniquement fondés sur la proximité spatiale et de grilles de lecture de l'espace facilement transposables d'un lieu à un autre ${ }^{6}$. À l'opposé, les groupes dont l'aptitude à la mobilité est la plus faible courent le risque de l'isolement et de la marginalisation? ${ }^{7}$. Laccroissement de la dépendance automobile ${ }^{8}$ renforce ce phénomène en accentuant les problèmes d'accessibilité aux ressources urbaines des ménages non ou faible-

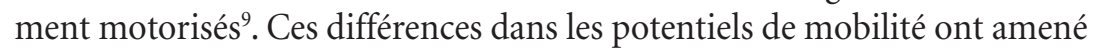
Vincent Kaufmann ${ }^{10}$ à introduire le concept de motilité, défini comme un capital, dont la distribution est inégalitaire.

C'est à partir de ce constat que des politiques publiques tendant à favoriser l'accès à la mobilité urbaine des ménages dits «pauvres », qu'elle soit résidentielle ou liée aux déplacements, ont été développées ces dernières années dans plusieurs pays européens et en Amérique du Nord. Ces politiques partent d'un même postulat: la concentration de la pauvreté dans des territoires ségrégés est problématique en ce qu'elle engendre un proces-

4. Cette notion de ménages pauvres est insatisfaisante dans la mesure où elle reste souvent peu définie. Nous la conservons entre guillemets car elle est utilisée dans la plupart des travaux de recherche, en particulier nord-américains.

5. Pucher John, Renne John, «Socio-Economics of Urban Travel: Evidence from the 2001 NHTS ", in Transportation Quaterly, vol. 57, n 3, 2003, p. 49-77; Transports, pauvretés, exclusions. Pouvoir bouger pour s'en sortir, OrfeUIL JeanPierre, (dir.), Éditions de l'Aube, 2004; Social Exclusion Unit, Making the connections: final report on transport and social exclusion, Londres, HMSO, 2003.

6. Rémy Jean, Voyé Liliane, La Ville: vers une nouvelle définition, Paris, L'Harmattan, «Villes et Entreprises », 1992.

7. URry John, Sociology Beyond Societies. Mobilities for the Twenty-First Century, op. cit.; Transports, pauvretés, exclusions. Pouvoir bouger pour s'en sortir, op. cit.

8. Dupuy Gabriel, La Dépendance automobile, Paris, Anthropos, 1995.

9. Hine Julian, Mitchell Fiona, «Better for everyone? Travel experiences and transport exclusion ", in Urban Studies, vol. 38 (2), 2001, p. 319-322; CLIfToN Kelly, « Mobility Strategies and Food Shopping for Low-Income Families. A Case Study ", in Journal of Planning Education and Research, vol. 23, 2004, p. 402-413.

10. Kaufmann Vincent, Bergman Max, Joye Dominique, « Motility: Mobility as Capital ", in International Journal of Urban and Regional Research, vol. 28.4, 2004, p. 745-756. 
sus d'isolement spatial et social qui renforce les difficultés d'accès à l'emploi et les formes de dépendance sociale. Si l'immobilité est un obstacle à l'insertion sociale et économique, il faut donc promouvoir des politiques d'accès à la mobilité.

\section{LES POLITIQUES D’AIDE À LA MOBILITÉ DES MÉNAGES « PAUVRES »: DU DROIT À L'INJONCTION À LA MOBILITÉ}

Les politiques d'aide à la mobilité ont émergé dans les années quatrevingt-dix. Elles s'adressent aux citadins " pauvres » et résidant dans des quartiers «pauvres » pour favoriser leurs déplacements quotidiens et leur mobilité résidentielle. Il est frappant de constater la façon dont cette thématique s'est imposée dans des contextes socio-économiques très divers ${ }^{11}$.

\section{Les politiques d'aide aux déplacements des citadins "pauvres»}

L'aide au déplacement des «pauvres» est apparue comme un objectif majeur des politiques de transport et d'aide sociale menées dans les années quatre-vingt-dix aux États-Unis comme dans plusieurs pays d'Europe. En France, ce constat a été, depuis les années 1990, à l'origine de politiques territorialisées de désenclavement des quartiers en difficultés par l'amélioration de l'offre de transports collectifs ${ }^{12}$. En 1991, le rapport du Conseil National des Transports, "Transports et exclusion sociale", constate les inégalités de desserte entre quartiers et sert de base à la mise en place d'un volet "transports" dans la politique de la ville. Les contrats de ville intègrent progressivement la nécessité d'un «désenclavement des quartiers ».

Aux États-Unis, le Transportation Equity Act for the 21 $1^{\text {st }}$ Century (TEA-21) de 1998 définit comme priorité la prise en compte des besoins de déplacements des «pauvres » et des minorités ethniques. L'amélioration de la mobilité de ces ménages passe par une meilleure coordination des modes

11. Dans un précédent article nous avons mis en perspective les débats académiques et les politiques publiques des deux côtés de l'Atlantique en éclairant les emprunts scientifiques et politiques: BACQUÉ Marie-Hélène, Fol Sylvie, «Effets de quartier: enjeux scientifiques et politiques de l'importation d'une controverse ", in Le Quartier. Enjeux scientifiques, actions politiques et pratiques sociales, AutHIER Jean-Yves, Bacqué Marie-Hélène, Guérin-Pace France, (dir), Paris, La Découverte, 2007.

12. Harzo Christian, Mobilité des populations en difficultés: connaissance des besoins et réponses nouvelles, Document de synthèse, DIV et le Ministère de l'Emploi et de la Solidarité, 1998. 
de transports et des interventions des acteurs assurant que les « liaisons entre les personnes et les emplois, les biens et services et les différents quartiers » soient développées.

En Grande Bretagne, le premier rapport de la Social Exclusion Unit, créée en 1997 après le retour du gouvernement travailliste, insiste sur le « déficit d'accessibilité » de certains quartiers conjugué à la faiblesse et l'inadaptation des services publics. Des politiques d'amélioration de la desserte des quartiers défavorisés par les transports collectifs ont été mises en œuvre, et récemment englobées dans une approche plus large d'Accessibility Planning ${ }^{13}$.

Plus récemment, l'enjeu de la mobilité des " pauvres » s'est en partie réorienté dans la perspective des politiques de Workfare visant le retour à l'emploi des populations précarisées, le manque de mobilité étant avant tout considéré comme un obstacle à la recherche d'emploi. Les politiques se tournent alors vers des aides individuelles, cherchant à développer «l'employabilité » des individus et, pour ce faire, leur capacité à se déplacer.

Aux États-Unis, depuis la réforme du Welfare de 1996, les fonds fédéraux et locaux ont été utilisés massivement pour créer des programmes d'aide à la mobilité, comme le programme Access to Job, qui doit permettre l'adaptation des systèmes de transports en commun pour les salariés à bas revenus. Mais les solutions les plus fréquemment préconisées aujourd'hui concernent des aides individuelles à la motorisation. En France comme en Grande-Bretagne, les politiques « territorialisées » de désenclavement centrées sur l'offre de transports en commun ont été accompagnées ces dernières années de mesures ciblant davantage les individus. La notion de « transports à la demande » se développe tandis que les politiques publiques prennent de plus en plus en compte la réponse à des besoins diversifiés qui ne passe pas exclusivement par l'offre de transports en commun: politiques tarifaires en direction des personnes les plus démunies, aides aux déplacements de l'ANPE, aides à la motorisation ${ }^{14}$.

Émanant d'associations qui sont la plupart du temps soutenues par les collectivités locales, ces initiatives locales ont abouti à la mise en place d'aides à la mobilité dont une partie sont tournées vers l'usage de la voi-

13. Social Exclusion Unit, Making the connections: final report on transport and social exclusion, op. cit.

14. Le Breton Éric, Bouger pour s'en sortir. Mobilité quotidienne et intégration sociale, Paris, Armand Colin, 2005; Fol Sylvie, Coutard Olivier, Dupuy Gabriel, «Transport Policy and the Car Divide in the UK, the US and France: Beyond the Environmental Debate ", in International Journal of Urban and Regional Research, vol. 31-4, 2007, p. 802-818. 
ture $^{15}$. Dans certains cas, elles ont été relayées par la mise en place de programmes nationaux: Ways-to-Work aux États-Unis, Wheels-to-Work en Grande-Bretagne, aide au permis de conduire en France.

Ce glissement, plus ou moins affirmé selon les contextes, de politiques de désenclavement à une aide à la mobilité individuelle témoigne du succès d'une approche qui fait de la mobilité une ressource personnelle et un outil de l'insertion professionnelle.

\section{Les politiques de mobilité résidentielle}

Les politiques de mobilité résidentielle articulent deux dimensions, territoriale et individuelle. D'un côté, elles sont présentées comme un moyen de combattre la ségrégation spatiale et la cristallisation de la pauvreté dans l'espace urbain; de l'autre, elles permettraient aux ménages qui en bénéficient, d'échapper à la culture de la pauvreté et de bénéficier des atouts d'un «bon » voisinage.

Aux États-Unis, ces politiques sont en partie issues des actions en justice d'associations liées au mouvement des droits civiques, qui obtinrent de la Cour Suprême plusieurs jugements imposant des expériences de déségrégation. Il en est ainsi de l'expérience des Gautreaux à Chicago, du nom d'une militante des Droits civiques à l'initiative de la plainte. Ce programme visait à favoriser la mobilité des familles noires par l'octroi d'une aide personnalisée au logement, celui-ci devant obligatoirement être situé dans des quartiers aisés de l'agglomération. Il a servi de modèle à une expérimentation fédérale lancée en 1992, Moving to Opportunity, financée par le HUD (Ministère Fédéral du Logement et de l'Urbanisme), qui a débuté en 1994 dans cinq villes (Baltimore, Boston, Chicago, New York et Los Angeles) et a permis le relogement de 4500 familles habitant des logements sociaux (public housing) dans des quartiers dont au moins $40 \%$ des individus étaient considérés comme pauvres ${ }^{16}$. Mais ces aides individuelles à la mobilité ont également été développées pour accompagner la démolition de quartiers d'habitat social dans le cadre des programmes HOPE VI initiés en 1994 par l'administration Clinton. Par ailleurs, c'est au nom de la mobilité

15. Le Breton Éric, Bouger pour s'en sortir. Mobilité quotidienne et intégration sociale, op. cit.; Fol Sylvie, Coutard Olivier, Dupuy Gabriel, «Transport Policy and the Car Divide in the UK, the US and France: Beyond the Environmental Debate ", op. cit.

16. Goering John, Choosing a Better Life? Evaluating the Moving to Opportunity Social Experiment, The Urban Institute Press, 2003. 
résidentielle que, dès la fin des années soixante-dix, la construction de logements sociaux a été quasiment arrêtée au profit d'aides personnalisées.

La même évolution caractérise les politiques du logement menées en France une décennie plus tard. Récemment, la politique de rénovation urbaine engagée dans les quartiers « en difficultés » vise également à déplacer les ménages précarisés après démolition d'une partie des logements. Cette mobilité forcée est légitimée au nom d'une double assertion: habiter dans un quartier dit «difficile» ou "pauvre » serait doublement pénalisant, du point de vue de l'éloignement des secteurs d'emploi et en raison "d'effets de quartier » caractérisés par l'isolement social et la diffusion de normes « déviantes». Ces deux affirmations font l'objet de deux débats scientifiques articulés.

\section{LES DÉBATS THÉORIQUES \\ SUR LES EFFETS DE L'IMMOBILITÉ DES « PAUVRES »}

La recherche urbaine nord-américaine a abordé de longue date la question des effets de l'absence de mobilité sur les conditions de vie et le destin social des ménages "pauvres» et/ou appartenant aux minorités ethniques. Cette thématique a été nourrie de travaux émanant de perspectives différentes mais qui convergent dans le fait de considérer l'immobilité comme problème. En effet, selon l'hypothèse du spatial mismatch, les processus de ségrégation, conjugués aux effets de la décentralisation des emplois, ont eu pour résultat d'éloigner les individus appartenant aux minorités ethniques, concentrés pour la plupart dans les centres-villes déshérités, des opportunités d'emplois localisées généralement en périphérie. Quant aux travaux sur les effets de quartier, ils partent de l'hypothèse selon laquelle la concentration durable de citadins précarisés dans certains espaces a pour effet de renforcer les effets négatifs de la pauvreté sur les destins sociaux des individus et ménages concernés. Dans les deux cas, la mobilité est invoquée comme moyen de sortir de l'isolement spatial et social créé par la ségrégation.

\section{L'hypothèse du spatial mismatch}

John F. Kain, en 1968, est le premier chercheur à mettre en évidence, à partir d'un travail sur Chicago et Detroit, l'impact de la discrimination résidentielle sur l'emploi des minorités noires. Il montre que la ségrégation résidentielle affecte à la fois la distribution spatiale de l'emploi des Noirs et leur taux de chômage, et que le mouvement de suburbanisation des emplois a tendance à aggraver ces problèmes. Parmi les nombreux travaux qui s'en 
inspirent, appuyés sur des recherches empiriques, certains comparent les temps et les distances domicile-travail entre les salariés blancs et ceux appartenant à certaines minorités ethniques, Noirs et Hispaniques ${ }^{17}$. D'autres cherchent à mesurer l'impact de la distance à l'emploi sur les chances de sortie du chômage des individus "pauvres" ou appartenant aux minorités ethniques ${ }^{18}$. La plupart concluent à l'importance du facteur spatial dans les difficultés d'accès à l'emploi de ces populations, l'éloignement et le manque de mobilité se conjuguant pour les maintenir dans une situation d'isolement par rapport aux opportunités d'emploi. Plus récemment, les recherches se sont centrées sur la mesure de l'impact d'une amélioration des moyens de transport sur l'accès à l'emploi et ont abouti à des conclusions convergentes ${ }^{19}$.

Cependant, la thèse du spatial mismatch reste controversée. Le débat porte en premier lieu sur les rôles respectifs de l'espace, de la classe et de la race pour expliquer les difficultés d'accès à l'emploi des ménages les plus «pauvres». En particulier, Ellwood ${ }^{20}$ ou Massey et Denton ${ }^{21}$ mettent en avant les barrières raciales comme obstacle principal à l'emploi des minorités. Le rôle de l'éloignement géographique dans les difficultés d'emploi des individus appartenant aux minorités ethniques est également relativisé au regard de facteurs déterminants tels que les caractéristiques individuelles (formation, qualification) et les conditions du marché du travail (chômage, état de l'offre d'emploi) ${ }^{22}$.

17. Taylor Bryan et Ong Paul, «Spatial Mismatch or Automobile Mismatch? An Examination of Race, Residence and Commuting in US Metropolitan Areas ", in Urban Studies, vol. 32, n 9, 1995.

18. IhLANFeldt Keith, «The spatial mismatch between jobs and residential locations within urban areas ", in Cityscape, n ${ }^{\circ}$ 1, 1994, p. 219-44; ONG Paul et BLUMenberg Evelyn, "Job Access, Commute and Travel Burden among Welfare Recipients », in Urban Studies, vol. 35, n 1, 1998, p. 77-93.

19. Raphael Steven, Stoll Michael, «Can boosting minority car ownership rates narrow inter-racial employment gap? ", in Working Paper $n^{\circ}$ W00-002, IBEN, UCB; Blumenberg Evelyn, "On the Way to Work: Welfare Participants and Barriers to Employment ", in Economic Development Quarterly, vol. 16, $\mathrm{n}^{\circ}$ 4, 2002, p. 314-325.

20. Ellwood David T., «The Spatial Mismatch Hypothesis: Are There Teenage Jobs Missing in the Ghetto? » in The Black Youth Unemployment Crisis, Freeman R.B., Holzer H.J. (dir.), Chicago, University of Chicago Press, 1986.

21. Massey Douglas, Denton Nancy, American Apartheid: Segregation and the Making of the Underclass, Cambridge, Harvard University Press, 1993.

22. O’Regan Kathryn, Quigley John, « Spatial Isolation and Welfare Recipients: What Do We Know? », IBEN, UCB, Working Paper n 99-003. 
Dans la période récente, la thèse du spatial mismatch s'est diffusée de manière significative en Europe. En Grande-Bretagne, différents travaux s'inscrivent dans ce débat sans y apporter de conclusion très tranchée $e^{23}$. Le spatial mismatch ne serait donc qu'un facteur parmi d'autres, secondaire sans doute, dans le sur-risque de chômage touchant les individus membres des minorités ethniques ${ }^{24}$.

En France, les travaux empiriques s'inspirant de la thèse du spatial mismatch sont encore peu nombreux et ne dégagent pas non plus de ligne affirmée. À partir de travaux sur les Zones Urbaines Sensibles ou d'enquêtes sur les trajectoires des demandeurs d'emploi (DARES), le rôle de la distance aux emplois et le manque de moyens de transports dans l'explication du chômage est mis en évidence ${ }^{25}$. Les travaux de Sandrine Wenglenski ${ }^{26}$ débouchent sur une conclusion mitigée: si les distances au travail et les durées de navettes effectives sont très proches entre les catégories sociales, des disparités existent en termes d'accessibilité des marchés de l'emploi.

Pourtant, les effets négatifs du manque de mobilité semblent un postulat acquis dans la littérature urbaine hexagonale. Le confinement spatial des ménages "pauvres » dans des quartiers de " relégation » se traduirait par une immobilité volontaire de ces ménages et par une attitude de repli ${ }^{27}$. Les individus qui ne sont pas en mesure de se déplacer à la hauteur des exigences de la société contemporaine seraient condamnés à l'isolement relationnel ou enfermés dans une "désastreuse immobilitée ${ }^{8}$ ». Ils seraient alors soumis à un risque croissant de précarisation et de marginalisation.

23. Fieldhouse Edward, «Ethnic minority unemployment and spatial mismatch: the case of Londres ", in Urban Studies, vol. 36, n 9, 1999, p. 1569-96.

24. Fol Sylvie, Coutard Olivier, Dupuy Gabriel, « Transport Policy and the Car Divide in the UK, the US and France: Beyond the Environmental Debate ", op. cit.

25. Choffel Philippe, Delattre Éric, Effets locaux et urbains sur les parcours de chômage, THEMA, Mimeo, 2002; Gobillon Laurent, Selod Harry, "Comment expliquer le chômage des banlieues? Le problème d'accès à l'emploi et de ségrégation résidentielle en Ile-de-France ", in Working Paper, CREST, 2002 ; CAvaco Sandra, Lesueur Jean-Yves, "Contraintes spatiales et accès à l'emploi: Applications microéconométriques à partir de l'enquête TDE ", in Documents de travail, Groupe d'Analyse et de Théorie Économique, 2002.

26. Wenglenski Sandrine, « Une mesure des disparités sociales d'accessibilité au marché de l'emploi en Île-de-France ", in Revue d'Économie Régionale et Urbaine, $\mathrm{n}^{\circ} 4,2004$, p. 539-550.

27. Donzelot Jacques, «La ville à trois vitesses: relégation, périurbanisation, gentrification ", in Esprit, n' 303, 2004.

28. Lévy Jacques, «Les nouveaux espaces de la mobilité », op. cit., p. 155-170. 
La vie quotidienne de ces « insulaires » se déroulerait donc dans d'étroites enclaves, qui seules permettent une certaine familiarité rassurante et une moindre contrainte, mais dont l'exclusive fréquentation les condamnerait à l'isolement relationnel ${ }^{29}$. Ces analyses ne sont pas sans parenté avec la thèse des effets de quartier, centrée elle aussi sur les effets du « confinement spatial » des citadins « pauvres ».

\section{L'hypothèse des effets de quartier}

La thèse des effets de quartier pose que la concentration des ménages "pauvres » dans des quartiers isolés spatialement et socialement du reste de la société urbaine a pour effet de redoubler les conséquences de la pauvreté en termes d'accès à l'emploi, de résultats scolaires ou de comportements dits déviants. Elle prend en partie sa source dans les travaux développés autour des notions d'underclass et de capital social. La notion d'underclass, introduite par Gunnar Myrdal en 1962, a été reprise par le sociologue William J. Wilson ${ }^{30}$. Tout en dénonçant les causes structurelles de la pauvreté des populations noires et de leur concentration dans les ghettos, Wilson désigne par le terme underclass un groupe constitué d'individus confrontés à de longues périodes de pauvreté et à un chômage structurel, dépendants de l'aide sociale, vivant dans une situation d' ' isolement social » croissant et caractérisés par des traits comportementaux tels que l'affaiblissement des liens au travail, l'augmentation de la part des familles monoparentales, les difficultés à se marier, l'échec scolaire... Selon les approches en termes de capital social, les quartiers " pauvres » sont caractérisés par un isolement spatial et social qui priverait les individus qui y vivent de contacts avec des personnes appartenant à d'autres groupes sociaux. Et si les réseaux sociaux internes au quartier existent, le capital social qu'ils représentent n'aurait guère d'utilité pour les habitants des quartiers «pauvres » car il ne leur permet pas d'ouverture vers d'autres univers sociaux, seule clé d'accès aux emplois ou à la réussite sociale. Cette approche, développée par Putnam ${ }^{31}$ prolonge celle de Mark Granovetter ${ }^{32}$

29. Le Breton Éric, Bouger pour s'en sortir. Mobilité quotidienne et intégration sociale, op. cit.

30. Wilson Wiliam Julius, The Truly Disadvantaged: The Inner City, the Underclass, and Public Policy, Chicago, Chicago University Press, 1987.

31. Putnam Robert, Bowling alone. The Collapse and Revival of American Community, New York, Simon and Schuster, 2000.

32. Granovetter Mark, "The strength of weak ties ", in American journal of sociology, $\mathrm{n}^{\circ} 78,1973, \mathrm{p} .1361-1380$. 
qui distingue liens forts et liens faibles: les seconds, noués à l'extérieur de la communauté et du voisinage, dans le cadre professionnel par exemple, sont considérés comme les plus efficaces dans la recherche d'emploi.

L'hypothèse des effets de quartier a également été influencée par les théories de la "contagion", développées notamment par $\mathrm{Crane}^{33}$ qui en a emprunté le modèle mathématique à l'épidémiologie. Les problèmes sociaux seraient en effet contagieux et se répandraient par l'influence des groupes de pairs. Comme pour les maladies, il existerait des niveaux critiques d'incidence des problèmes sociaux au sein de la population, au-delà desquels les problèmes se répandent de manière exponentielle: l'épidémie se déclare. Certains types de population seraient plus sensibles à la contagion: les enfants de familles monoparentales, les hommes "pauvres" vivant en milieu urbain, les adolescentes noires « pauvres »...

Cette thèse fait l'objet, en Amérique du Nord, d'un débat tout aussi animé que celle du spatial mismatch. Des travaux nombreux se sont penchés sur l'influence du quartier, analysée selon différents registres: comportement des individus aux différentes périodes de la vie, et en particulier effets sur les conduites délinquantes; état de santé; niveau de « développement » des enfants et réussite scolaire; accès à l'emploi et insertion professionnelle des jeunes et des adultes. Différentes synthèses ${ }^{34}$ en dégagent des résultats mitigés sans conclusion claire. Si l'environnement social du quartier semble jouer un rôle dans les socialisations, la « réussite » et l'insertion sociale des individus, il reste très difficile de distinguer, parmi ces effets, ce qui relève du quartier à proprement parler et ce qui ressort des caractéristiques sociales des individus et des familles.

Un autre volet de recherche plus récent, émane des évaluations des opérations de déségrégation ${ }^{35}$. Mais ces évaluations peinent à confirmer l'hy-

33. Crane John, "The Epidemic Theory of Ghettos and Neighborhood Effects on Dropping Out and Teenage Childbearing ", in The American Journal of Socio$\log y$, vol. 96, $\mathrm{n}^{\circ}$ 5, 1991, p. 1226-1259.

34. Ellen Ingrid, Turner Margery, "Does Neighborhood Matter? Assessing Recent Evidence », in Housing Policy Debate, vol. 8, n 4, 1997, p. 833-866; BrooksGunN Jane et al., "Do Neighborhood Influence Child and Adolescent Development? ", in The American Journal of Sociology, vol. 99, $\mathrm{n}^{\circ}$ 2, 1993, p. 353-395; Marpsat Maryse, "La modélisation des effets de quartier aux États-Unis, une revue des travaux récents ", in Population, n 54 (2), 1999.

35. Goering John, Choosing a Better Life? Evaluating the Moving to Opportunity Social Experiment, op. cit.; BRIGGs Xavier, The Geography of Opportunity: Race and Housing Choice in Metropolitan America, Washington DC, Brookings Institution Press, 2005; Comey Jennifer, Briggs Xavier, Weismann Gretchen, «Struggling to 
pothèse des effets de quartier. Si le déménagement dans des quartiers aisés a permis à certains ménages d'échapper à l'insécurité, d'améliorer leur état de santé et à leurs enfants de bénéficier de meilleures conditions de scolarité, les résultats des programmes de mobilité en termes d'insertion professionnelle et sociale sont très décevants ${ }^{36}$. Pour d'autres ménages, le déménagement s'est traduit par un isolement social accentué et de nouvelles difficultés, qui les amènent dans un nombre de cas significatif à retourner vivre dans leur ancien quartier ${ }^{37}$. De fait, la croyance dans les bienfaits d'un prétendu modèle de comportement offert par les couches moyennes, de même que l'hypothèse d'un effet intégrateur par les réseaux sociaux accessibles aux ménages pauvres dans les quartiers aisés, sont l'une et l'autre battues en brèche par les résultats des expérimentations:

In sum, these studies consistently show that the social relationships among members of different economic groups are quite limited, even within the same neighborhood or housing complex. Members of the lower-status group often do not take advantage of propinquity to broaden their "weak ties " and enhance the resource-producing potential of their networks; instead, they often restrict their networks to nearby members of their own group or to those remaining in the "old neighborhood». This suggests that social networking may be a powerful neighborhood force among members of a given group, but less so in an inter-group context, where perhaps the role model and social control mechanisms operate more strongly ${ }^{38}$.

De manière générale, les évaluations les plus récentes donnent des conclusions extrêmement nuancées, voire défavorables à la thèse des effets de quartier: "There is a general agreement across recent and earlier literature that outcomes are more affected by individual and familial characteristics

Stay Out High-Poverty Neighborhoods: Lessons from the Moving to Opportunity Experiment ", in Urban Metropolitan Housing and Communities Center, Brief $n^{\circ} 6$, Urban Institute, mars 2008, p. 1-12.

36. Musterd Sako, Andersson Roger, «Employment, Social Mobility and Neighbourhood Effects: The Case of Sweden ", in International Journal of Urban and Regional Research, vol.30.1, 2006, p. 120-140; Galster George, Santiago Anne, « What's the 'Hood got to do with it? Parental Perceptions about how neighborhood mechanisms affect their children ", in Journal of Urban Affairs, vol. 38, $\mathrm{n}^{\circ} 3$, 2006, p. 201-226.

37. Comey Jennifer, Briggs Xavier, Weismann Gretchen, "Struggling to Stay Out High-Poverty Neighborhoods: Lessons from the Moving to Opportunity Experiment", op. cit, p. 1-12.

38. Galster George, Santiago Anne, "What's the 'Hood got to do with it? Parental Perceptions about how neighborhood mechanisms affect their children ", op. cit. 
than by neighborhood characteristics ${ }^{39}$. " Dès lors, si les effets de contexte jouent bien dans le destin des ménages, on ne saurait pour autant les appréhender de façon simpliste et homogène. Interviennent ici les trajectoires sociales et familiales mais aussi différentes dimensions sociales, spatiales et institutionnelles de l'organisation urbaine des quartiers dont ne rend pas compte la catégorie de quartier " pauvre » ou quartier « aisé ${ }^{40}$ ».

La thématique des effets de quartier a été reprise au Canada et en Europe (en particulier en Suède, Allemagne, Grande-Bretagne et aux Pays-Bas). Plusieurs auteurs mettent toutefois en avant les différences de contextes: les inégalités socio-spatiales sont probablement moins criantes du fait de politiques publiques beaucoup plus redistributives qu'aux États-Unis, qui contribueraient à relativiser les effets de quartier ${ }^{41}$. Comme les travaux états-uniens, les travaux européens montrent des résultats contradictoires. En Grande-Bretagne, Buck ${ }^{42}$ conclut que les composantes individuelles de l'exclusion sociale sont corrélées aux caractéristiques du quartier de résidence. Atkinson et Kintrea ${ }^{43}$ affirment à partir de leurs travaux quantitatifs et qualitatifs qu'il est "pire d'être pauvre dans un quartier pauvre que dans un quartier mixte " mais ils évoquent également l'influence du contexte dans lequel se situe le quartier (état du marché de l'emploi, proximité des équipements publics, effets de stigmatisation, etc) et le rôle décisif des réseaux sociaux sur les trajectoires des habitants. L'analyse de Brännström ${ }^{44}$ sur les

39. Berube Alan, Overcoming barriers to mobility: the role of place in the United States and UK, The Brookings Institution, 2005.

40. Pour une synthèse détaillée de ces travaux, voir: BACQuÉ Marie-Hélène, FoL Sylvie, "Ségrégation et politiques de mixité sociale aux États-Unis ", in Informations Sociales, $\mathrm{n}^{\circ} 125,2005$, p. 82-93; BACQué Marie-Hélène, Fol Sylvie, "Effets de quartier: enjeux scientifiques et politiques de l'importation d'une controverse ", in Le Quartier. Enjeux scientifiques, actions politiques et pratiques sociales, op. cit.

41. Rose Damaris, SÉguin Anne-Marie, "Les débats sur les effets de quartier: que nous apprennent les approches centrées sur les réseaux sociaux et le capital social? ", in Le Quartier. Enjeux scientifiques, actions politiques et pratiques sociales, $o p$. cit.; FrIEDRICHS Jürgen, "Response: Contrasting US and European Findings on Poverty Neighbourhoods », in Urban Studies, vol. 17, n 1, 2002, p. 101-104.

42. Buck Nick, «Identifying Neighbourhood Effects on Social Exclusion », in Urban Studies, vol. 38, n 12, 2001, p. 2251-2275.

43. Atkinson Robert., Kintrea Keith., "Disentangling Area Effects: Evidence from Deprived and Non-deprived Neighborhoods ", in Urban Studies, vol. 38, $\mathrm{n}^{\circ} 12,2001$, p. 2277-2298.

44. BRÄnnström Lars, « Poor Places, Poor Prospects? Counterfactual Models of Neighbourhood Effects on Social Exclusion in Stockholm, Sweden ", in Urban Studies, vol. 41, $\mathrm{n}^{\circ} 13,2004$, p. 2515-2537. 
destins de deux groupes d'enfants aux caractéristiques similaires vivant dans différents types de quartier de Stockholm à l'adolescence conclut à l'absence d'effets de quartier. Drever ${ }^{45}$ montre de son côté que les immigrants vivant dans des quartiers «ethniques » ne sont pas plus isolés des citadins allemands que leurs homologues vivant dans des quartiers mixtes.

En France, une vague de travaux portant sur la ségrégation reprennent à leur compte une partie des résultats des travaux américains, sans toutefois les situer dans le débat scientifique et politique. Ainsi, Maurin ${ }^{46}$ met en avant les effets positifs du déménagement des familles «pauvres » dans des quartiers plus favorisés, notamment en termes d'amélioration de la santé des enfants et de leur comportement. De même, Goux et Maurin ${ }^{47}$ s'ins- $^{\text {' }}$ pirent explicitement des questions et des méthodes des travaux américains pour démontrer une forte corrélation entre les résultats scolaires et le milieu (défini par le niveau social du voisinage ou la date de naissance des enfants du voisinage). Ces analyses, qui rencontrent un important écho médiatique, tendent à produire un discours réducteur sur la nature des processus de ségrégation et leurs effets, qui n'est pas sans incidence sur la construction des politiques publiques. De la mise en évidence des impacts négatifs de la ségrégation, le discours passe à une dénonciation sans nuances des effets nocifs de la vie dans les quartiers pauvres et en conclut que la dispersion des ménages habitant ces quartiers au moyen de politiques de mobilité résidentielle est une nécessité. Le caractère " hégémonique » de ce type d'analyse fait aujourd'hui l'objet de critiques émergentes aux ÉtatsUnis. Certains auteurs ${ }^{48}$ soulignent la dimension partisane des travaux sur les effets de quartier, qui tendent à produire, à partir de résultats de

45. Drever Anita, "Separate Spaces, Separate Outcomes? Neighbourhood Impacts on Minorities in Germany ", in Urban Studies, vol. 41, $\mathrm{n}^{\circ}$ 8, 2004, p. 1423-1439.

46. Maurin Éric, Le Ghetto français. Enquête sur le séparatisme social, Paris, Éditions du Seuil, 2004.

47. Goux Dominique, Maurin Éric, « Neighborhood Effects on Performances at School », in Working Paper, CREST, 2004.

48. Imbroscio David, « United and Actuated by Some Common Impulse of Passion: Challenging The Dispersal Consensus in American Housing Policy Research », in The Journal of Urban Affairs, vol. 30, $\mathrm{n}^{\circ} 2,2008$, p. 111-130; CHApple Karen, Goetze Edward, «Spatial justice through regionalism: The inside game, the outside game, and the quest for the spatial fix in the US », Présentation à la Conférence " Justice et injustices spatiales », université Paris Ouest Nanterre La Défense, 12-14 mars 2008. 
recherche très contradictoires, des conclusions sans appels de même qu'une forme de «consensus » sur les bienfaits des politiques de déségrégation ${ }^{49}$.

Ainsi, aux États-Unis comme en Europe, se développent des analyses qui tendent à considérer l'absence de mobilité comme une composante importante de l'exclusion professionnelle et sociale. L'immobilité est fréquemment assimilée au repli sur le quartier et à l'enfermement dans l'espace local. Elle est même parfois définie non pas comme une conséquence de la pauvreté mais comme l'une de ses causes, renvoyant ainsi à la thèse de la culture de la pauvreté, dans laquelle ce sont les traits de comportements des pauvres qui sont à l'origine de leur situation et non l'inverse. Pourtant, il semble que ces analyses ignorent certaines dimensions essentielles des pratiques de mobilité des ménages "pauvres » et en particulier celles qui concernent la mobilisation des ressources de la proximité.

\section{L'IMMOBILITÉ COMME RESSOURCE?}

Ces analyses paraissent en effet minimiser une dimension essentielle, qui est celle des ressources locales et de leur rôle pour les ménages pauvres.

\section{L'importance des ressources locales dans le domaine de l'emploi}

Si l'absence de mobilité est certes une composante importante de l'expérience de la pauvreté, la distance spatiale aux emplois n'est pas nécessairement déterminante dans les processus d'exclusion professionnelle. L'importance du facteur mobilité dans l'accès à l'emploi est ainsi relativisée par des travaux qui mettent en avant le caractère local du marché de l'emploi des ménages "pauvres» et appartenant aux minorités ethniques ${ }^{50}$. Cette situation résulte de différents facteurs. Ainsi, l'éloignement ne garantit pas des salaires plus élevés alors qu'il représente un coût: pour les salariés non qualifiés, l'élargissement de l'espace de recherche d'emploi ne permet pas nécessairement d'augmenter la rémunération. Ong et Blumenberg $^{51}$ montrent que, pour les bénéficiaires du Welfare, contrairement aux

49. Pour un aperçu des débats récents sur cette question, nous renvoyons à un numéro spécial du Journal of Urban Affairs (vol. 30, $\mathrm{n}^{\circ} 2,2008$ ) consacré aux politiques de déségrégation.

50. Shen Qing, «A Spatial Analysis of Job Openings and Access in a U.S. Metropolitan Area », in Journal of the American Planning Association, vol. 67 (1), 2001.

51. Ong Paul, Blumenberg Evelyn, « Job Access, Commute and Travel Burden among Welfare Recipients », in Urban Studies, vol. 35, nº 1, 1998, p. 77-93. 
actifs qualifiés, l'allongement des distances domicile-travail n'induit pas des salaires plus élevés. Chez ces ménages, la proximité de l'emploi a au contraire pour effet de réduire les coûts de l'éloignement (transports, mais aussi éventuels frais de garde d'enfants) et d'augmenter leurs revenus. Cette analyse est corroborée par des travaux menés dans le contexte français: pour les salariés non qualifiés, l'élargissement de l'espace de recherche d'emploi ne permet pas nécessairement d'augmenter la rémunération ${ }^{52}$.

Par ailleurs, pour certaines catégories de salariés, la mobilité géographique est extrêmement difficile à gérer. Le caractère local du marché de l'emploi des pauvres est ainsi encore accentué chez les femmes. Chapple ${ }^{53}$ montre ainsi que si les femmes peu qualifiées limitent leur recherche à des emplois locaux, c'est parce qu'elles savent qu'elles manquent des qualifications leur permettant d'être "compétitives» sur un marché du travail à l'échelle régionale. Pour les femmes à la tête de familles monoparentales qui constituent une part importante des chefs de ménage "pauvres", les limitations de l'espace géographique de la recherche d'emploi sont évidentes: temps contraint par les enfants et les tâches d'intendance familiale; fréquence plus importante des horaires décalés ${ }^{54}$. Hanson et $\operatorname{Pratt}^{55}$ ont bien montré qu'afin de remplir leur rôle familial, les femmes sont amenées à restreindre leur aire de recherche d'emploi et à privilégier les emplois locaux, surtout si elles sont peu qualifiées. Cette limitation est particulièrement forte pour les femmes non motorisées. Ces travaux indiquent aussi que les femmes peu qualifiées dépendent surtout de réseaux informels pour l'accès à l'information sur les emplois disponibles; elles effectuent donc des recherches qui débouchent fréquemment sur des emplois de proximité, là où leurs réseaux sociaux sont en général les plus denses. Cet effet de proximité est renforcé par le fait que la plupart des employeurs préfèrent recruter par bouche-à-oreille. On retrouve les mêmes conclu-

52. Vignal Cécile, «Logiques professionnelles et logiques familiales: une articulation contrainte par la délocalisation de l'emploi ", in Sociologie du Travail, $\mathrm{n}^{\circ}$ 47, 2005, p. 153-169.

53. Chapple Karen, « Time to Work: Job Search Strategies and Commute Time for Women on Welfare in San Francisco ", in Journal of Urban Affairs, vol. 23, n 2, 2001, p. 155-173.

54. Fol Sylvie, Mobilité des pauvres et rapports au territoire, Mémoire pour l'Habilitation à diriger des recherches, Université Paris 1 Panthéon-Sorbonne, 2005.

55. Hanson Susan, Pratt Geraldine, « Dynamic Dependencies: A Geographic Investigation of Local Labor Markets ", in Economic Geography, vol. 68, n 4, 1992, p. 373-405. 
sions dans les travaux français soulignant le rôle des réseaux sociaux dans l'accès à l'emploi des salariés peu qualifiés ${ }^{56}$.

\section{Réseaux sociaux et ressources de la proximité}

Parmi les ressources localisées, fondées sur la proximité, les réseaux sociaux tiennent donc une place essentielle et si une partie de la littérature sur les effets de quartier a tenté de montrer le caractère enfermant de ces réseaux, d'autres approches indiquent qu'ils jouent un rôle non négligeable dans l'accès à l'emploi et plus généralement, dans les processus d'insertion sociale des ménages " pauvres".

Pour les ménages "pauvres", la proximité des réseaux sociaux, tout comme la familiarité qui s'est instaurée de longue date avec les lieux comme avec leurs habitants, créent un environnement sécurisant et produisent des attaches. En France, les travaux sociologiques sur les réseaux familiaux, notamment ceux issus de l'enquête " Proches et Parents » mentionnés plus haut ${ }^{57}$ ont montré que la proximité spatiale des réseaux familiaux favorise un ancrage local beaucoup plus fort chez les ouvriers et les employés que chez la plupart des autres catégories sociales, en particulier les cadres. Dans les travaux américains, le rôle des réseaux sociaux localisés pour les ménages " pauvres » est également mis en avant. Ainsi, les personnes vivant dans des quartiers «pauvres » ont plus de chances d'avoir des liens forts centrés sur la famille et le voisinage que celles vivant dans des quartiers plus aisés. Sandra Barnes ${ }^{58}$ montre que pour les familles " pauvres ", les réseaux familiaux sont des pourvoyeurs essentiels de services et d'entraide comme les gardes d'enfants ou l'hébergement. Pour Karen Chapple ${ }^{59}$, le recours aux réseaux sociaux est une véritable stratégie spatiale de la part des femmes "pauvres ", qui conduit à une limitation volontaire du périmètre de la recherche d'emploi (après évaluation des coûts de déplacements et du gain éventuel en

56. Degenne Alain, Forsé Michel, Les Réseaux sociaux, $2^{\mathrm{e}}$ édition, Paris, Armand Colin, 2004.

57. Bonvalet Catherine, Gotman Anne, Grafmeyer Yves, La Famille et ses proches, l'aménagement des territoires, Paris, INED/PUF, 1999.

58. BARnes Sandra, « Determinants of Individual Neighborhood Ties and Social Resources in Poor Urban Neighborhoods ", in Sociological Spectrum, vol. 23, 2003, p. 463-497.

59. Chapple Karen, «Time to Work: Job Search Strategies and Commute Time for Women on Welfare in San Francisco ", op. cit. 
salaire). D'autres travaux ${ }^{60}$ insistent sur l'importance des réseaux de solidarité familiale, dont l'utilisation est centrale pour des ménages démunis souvent non motorisés. En effet, ces pratiques centrées sur l'espace local rendent la possession d'une voiture moins indispensable. En contrepartie, elles induisent une certaine captivité résidentielle qui accentue le processus de dépendance locale, les ménages concernés étant peu enclins à quitter un tel environnement Ainsi, dans les quartiers " pauvres », les réseaux sociaux, et surtout familiaux, jouent un grand rôle dans les pratiques territoriales et attachent d'une certaine manière les ménages « pauvres » au territoire local. Leur faible mobilité apparaît ainsi comme résultant non seulement des contraintes liées à leur manque de moyens, mais aussi à des stratégies visant à maximiser leur capacité à mobiliser des ressources qui, pour ces ménages, sont la plupart du temps concentrées dans des territoires restreints.

\section{Conclusion}

Ainsi, la montée en puissance de l'injonction à être mobile se heurte en partie à l'expérience des ménages "pauvres » et aux stratégies concrètes qu'ils mettent en oeuvre pour "s'en sortir». Pour des ménages dont les ressources sont en grande partie liées à la proximité, il existe des résistances plus ou moins fortes vis à vis de la mobilité, qu'elle soit quotidienne ou résidentielle. La mobilité représente un " coût » rarement pris en compte dans les recommandations politiques axées sur l'augmentation de la capacité des «pauvres » à se déplacer. En matière de déplacements, ce coût est d'abord financier, car l'accès aux transports, notamment à l'automobile, représente une charge souvent incompatible avec le budget des ménages " pauvres». Mais ce coût peut être d'un autre ordre, familial ou social, lorsque la mobilité amène à renoncer à des ressources centrées sur le territoire local.

Dans une période où la " mise en mouvement» des " pauvres » paraît s'affirmer, dans les politiques publiques, comme un outil important de leur insertion professionnelle et sociale, il semble nécessaire de réfléchir au sens de ces politiques et aux conditions de cette mise en mouvement. Dans certains cas, l'aide à la mobilité peut être le déclencheur d'un processus d'insertion professionnelle et sociale et il faut évidemment la favoriser. Dans d'autres cas, et surtout si l'encouragement à se déplacer devient injonction

60. Coutard Olivier, Dupuy Gabriel, Fol Sylvie, «La pauvreté périurbaine: dépendance locale ou dépendance automobile? ", in Espaces et Sociétés, n 108-109, 2002, p. 155-176. 
à être mobile, le risque est grand de fragiliser des individus dont une partie importance des ressources sont tirées de la proximité.

Pourtant, ces politiques publiques se réclament souvent de la justice sociale et en particulier de la théorie de la justice défendue par John Rawls qui soutient qu'une société approchant de l'idéal de justice peut reconnaître certaines inégalités sociales et économiques, à condition qu'elles bénéficient aux plus démunis. L'idée sous-tendant ce principe (dit « de différence ») est que la justice doit être considérée dans une perspective dynamique plutôt que statique: si certaines inégalités (liées par exemple au marché ou, dans le cadre discuté ici, aux politiques de mixité sociale) permettent que la collectivité concernée soit globalement plus riche que si une stricte égalité était imposée, les inégalités en question peuvent être justifiées. À une condition cependant: elles ne doivent pas seulement contribuer à augmenter le bien-être global, mais doivent plus particulièrement maximiser les ressources ou le bien-être des plus démunis. Indéniablement, les ménages et les groupes sociaux sont en situation inégale vis-à-vis de la mobilité. Mais le problème majeur des discours qui légitiment la mobilité au nom de la justice sociale est que le point clef de l'argumentation rawlsienne, à savoir la priorité accordée aux plus désavantagés, est la plupart du temps absent: la mobilité est d'abord envisagée comme enjeu économique ou pour faire disparaitre des quartiers paupérisés. Ces objectifs on l'a vu, ne servent que partiellement les ménages concernés et se retournent parfois en nouvelle contrainte. Par ailleurs, il revient aux plus démunis de définir, en discussion avec les autres parties prenantes, quels sont leurs intérêts. Cela permettrait sans doute de dégager d'autres politiques publiques en faveur de la justice spatiale par exemple celles consistant à améliorer durablement la qualité urbaine des quartiers populaires et à repenser la distribution spatiale et sociale des ressources urbaines et économiques. C'est sans doute ici un enjeu majeur: justice sociale et justice spatiale ne peuvent se construire sur des représentations négatives des ménages ou groupes concernés en leur imposant valeurs et modes de vie.

\section{Marie-Hélène BACQUÉ Université Paris Ouest Nanterre La Défense - UMR LAVUE}

Sylvie Fol Université Paris 1 Panthéon-Sorbonne, CRIA - UMR Géographie-Cités 
Postface 



\section{Spatial Justice as Viewed from Gauteng, South Africa: Professionals, Planning, Possibilities}

I S IT POSSIBLE TO CONTRIBUTE in durable ways to social justice through the construction and organisation of space? What are the possibilities of achieving "more" through planning and architecture? The reflections in this paper arise from engagement with questions of spatial difference and change in the Île-de-France region and from continuing engagement with the politics of social justice in South Africa, aspects of which have become more apparent through the very recent political history of the country. These experiences form the basis of reflection stimulated by the colloquium to reflect on what confronts professionals, "planners" of cities in the English language sense particularly or perhaps more helpfully urbanists in the French sense, in the deepening challenge of confronting urban injustice. By urban injustice I mean to begin with, decisions, distributions and forms of access which are deeply unequal and probably unfair, to use simple terms. While not coterminous with inequality, urban justice is inserted into that set of questions. Many forms of inequality, most with a spatial expression but not all showing the same geography - life and health; freedom and respect; material and symbolic resources ${ }^{1}-$ come to $^{-}$ mind. Architects and planners often claim and indeed believe themselves to be challenging urban injustice. What does experience reveal?

Many urban injustices interact with geographies and thus have expression as spatial injustices. The challenge of urban justice may be deepening in the face of massive suburbanisation in Johannesburg and Rio de Janeiro, or it may be deepening in the face of seemingly intractable alienations and divisions across seeming lines of language, class, colour and more in Paris and Cape Town. The settings in which professionals attempt to make ethical contributions to realising greater social justice do not seem to simplify and reflecting on what makes such efforts so hard seems a necessary exer-

1. Inequalities of the World: New Theoretical Frameworks, Multiple Empirical Approaches, Therborn Göran (ed.), London, Verso, 2006. 
cise to someone who has spent thirty years teaching and working with a sense of attempting urban change.

Therefore the paper which follows considers "what can be done" in accomplishing greater (spatial) justice (in cities). The paper draws on ideas, research and images from France, South Africa and some other places. It is not a comparative paper although it is set in the context of efforts to understand contemporary urbanism across diverse places ${ }^{2}$. It is rather a contribution which draws on stories from different cities and juxtaposes them with one another. It does this because I continue to be convinced that social justice is cosmopolitan... it is not something which will somehow be achieved in one place whilst lacking terribly in others. The ties binding cities worlds apart emerge more clearly if more confusingly as the globe tightens ${ }^{3}$.

The paper starts in the northeastern areas of the Paris region and traverses the city towards the southwest. The vertiginous separation between aspects of the social landscape of Ile-de-France reflects stark contrasts in the practices of at least one common actor whose work nonetheless connects those sections. That professional's practices lead on to Cape Town with its startling contrasts and depressing injustices. A further branch of the same person's actions (and impact) lead on to Johannesburg and its burgeoning inequalities. Here we are in territory usually associated with the infamy of apartheid - illustrating the close connection between social injustice and spatial systems, often represented as a special case of what David Harvey ${ }^{4}$ described. Meanings of social and spatial justice, seemingly so clearly delineated in the closing days of formal apartheid, become increasingly elusive as the stories unfold. Thus the paper in part reinforces the aptness of Dikeç's ${ }^{5}$ dialectic between spatiality of injustice and injustice of spatiality.

The Gauteng city region, with around 10 million people living within commuting distance of Johannesburg's centre, perhaps as much as any

2. As in Davis Diane and Tajвakhsh Kian, "Symposium: Globalization and cities in comparative perspective", in International Journal of Urban and Regional Research, 29 (1), 2005, p. 89-91.

3. Oldfield Sophie, Parnell Susan and Mabin Alan, "Engagement and reconstruction in critical research: negotiating urban practice, policy and theory in South Africa", in Journal of Social and Cultural Geography, vol. 5, n² 2, 2004, p. 285-299.

4. Harvey David, "Social Justice and Spatial Systems. Geographical Perspectives on American Poverty", in Antipode 4 (2), 1972, p.1-13.

5. Dikeç Mustafa, "Police, politics, and the right to the city", in Geojournal, vol. 58, Nos. 2-3, 2002, p. 96. 
illustrates how vital and yet seemingly impossible it is to address these spatialities. It is my halting attempts to grasp the dynamics and possibilities of change in social inequality and related practices. I have come to think, though, that whatever my own and other scholarly limitations, the problem for action is simply that it remains profoundly difficult to address justice, inequality, space and social change. The paper shows some ways in which they thread their tangled way together, viewed from work and residence in Gauteng, and in special relation to professional activities in the urban sphere. The question of what planning - urban planning, spatial planning - can do to contribute to the more "just city" becomes subject to only modest thoughts in the thicket of difficulties faced by citizens and professionals in the early twenty first century. In the end these difficulties lead us back to a city region renowned for its citizen struggles against radical injustices - 1789, 1848, 1871, 1944, 1968 and even 2009-a city in which, yet, possibilities of just citizenship seemingly remain elusive: Paris.

\section{ROISSY EXPRESS}

I have to admit that when I land at Aéroport Charles de Gaulle and take the RER B into Paris, I sometimes wait for a second faster train to depart, so as to travel without stopping in places such as Villepinte and Drancy on the way to and beyond the city. As represented by François Maspero and Anaik Frantz, the sector of Île-de-France traversed several times every hour by the "Roissy Express" reveals even from the windows of the train the pain of spatial distinction which haunts this great urban region, just as it does every city in the world.

Drancy is among the poignant zones through which the train passes ${ }^{6}$. Lost in its midst, the Cité du Square de la Liberation ("shut and locked") is surrounded by the U shape of the Cité de la Muette - revealing under the gallery on the right side of the Square, several marble plaques on the wall. One very briefly tells the inquisitive that between 1941 and 1944 this space became the site of the deportation camp at which 100000 men, women and children (mostly Jewish) were interned and sent on to the concentration camps where almost all of them died. The buildings, celebrated at their inception in the mid 1930s, are not on the site: they are the site. Maspero evokes the seamlessness with which these machines for living, modern apartment buildings built in hopes of addressing terrible shelter problems,

6. Maspero François, Roissy Express, P. Jones (trans.), photographs by Anaïk Frantz, London, Verso, 1994 [originally published as Les Passagers du Roissy-Express, Paris, Éditions du Seuil]. 
could be converted from public housing, to police barracks, to concentration camp, to detention centre for collaborators after liberation, and back to public housing.

The question in my mind as I pause in Drancy is not the same as that which animates Mustafa Dikeç. Whilst he seeks to construct a geography and logic of "resistance behind the revolts", my exploration of Drancy and Sarcelles is more about trying to grasp some elements of the diversity of conditions and approaches to life displayed and practised by those I see living in these huge areas - where most of France lives today, in a sense.

People are living there, as Athol Fugard wrote of the dying days of Braamfontein in its original terraced house form in Johannesburg ${ }^{8}$ - an idea readily transposed to the inner sections of other South African cities where the play was performed... but I digress too quickly to another series of urban islands far south of Île-de-France. In Drancy and its neighbours of course there is a culture of resistance to something not too easily defined, in the midst of teenage boredom and the grinding tectonics of different ways of being across genders, languages, beliefs, ideas and ways of engaging people. People are living here, in very many ways. Ways which have remade uses of space and do so daily. Space is malleable and dramatically so, something which a pause at La Muette amply reminds. That there are many people living there who struggle, who face unfairness and much worse in the course of daily life, is also evident. It is banal to note that the conditions of life in Drancy bear not very easy comparison with those on the other side of the city, where RER B emerges towards Gentilly, Arcueil and Bourg-laReine. There are certainly signs of similar histories in some of these places. But by the time the train passes Sceaux and stops at Antony, a very strong sense of different spaces and different opportunities of life surely impress themselves on most passengers (a diversity of space well described by Vieillard-Baron ${ }^{9}$ ).

Indeed, the passengers are very seldom the same people as those seen in the carriages passing Drancy and Le Bourget to the north east. South and west of Sceaux is distinctly another side of Paris (underneath Paris if the idea that most of Africa is under the Sahara is transposed: but perhaps it is

7. Dikeç Mustafa, "Revolting Geographies: Urban Unrest in France”, in Geography Compass, vol. 1 n 5, 2007, p. 1190-1206.

8. Fugard Athol, People are living there: a play in two acts, Cape Town, Oxford University Press, 1970.

9. Vieillard-Baron Hervé, Les Banlieues: Des singularités françaises aux réalités mondiales, Paris, Hachette, 1999. 
places like Drancy which resemble more the underside of the city region). Yet of course they are tightly linked, and not only by the RER B. At Antony - of course a site of immense Corbusian cités - one may nonetheless observe quite distinct environments. A short walk from the station and one arrives at a monument to one of the architects of La Muette: the contemporary art museum at Maison Eugene Beaudoin. This is a house, perhaps more a mansion compared with the narrow windowed flats of La Muette, which memorializes the very large contribution of this, among many, modernist architects of Paris. Associating Beaudoin (and Lods) with the buildings of La Muette would be less intuitive, perhaps, had the traverse across the city started here in Antony rather than in the midst of the famous ensemble of La Muette. Contemplating the practices of professionals architects, urbanists, planners, and others - who directly placed their marks on the Paris of the middle third of the twentieth century - leads to some difficulty in apprehending their roles in contributing to what superficially appears to be the stark history of spatial injustices which reveal themselves across the map of the region. Yet we remember the welcome and celebration of modern public housing through those decades, indeed something still celebrated in cities such as Berlin ${ }^{10}$. The legacies of modernism and forms of justice and injustice in the city are most certainly varied.

Obviously I do not intend here to explore in detail the social segregations of Paris... which would require us to refer to vast literatures and the enormous complexities of social fragmentation and more which they entail ${ }^{11}$. Some are puzzled, or even brutal in their observations on the city. Fred Khumalo's columns in the Sunday Times (Johannesburg) during 2008 gently point to the disparities of Paris as puzzle. Another South African observer, Breyten Breytenbach describes how "The Arabs either drowned when the police threw them into the Seine during street demonstrations or disappeared into high-rising no man's land 'zones' in suburban cités and their old haunts became a much sought-after area for the yuppies and the rich fils à $p a p a^{12}$." Rather I am suggesting nothing more than some additional ways of thinking about space to read the world (penser l'espace pour lire

10. Housing Estates in the Berlin Modern Style, Haspel Jörg and JAEggi Annemarie (eds), Berlin, Deutsche Kunstverlag, 2007.

11. Rhein Catherine, Elissalde Bernard, "La fragmentation sociale et urbaine en débats", in L'Information géographique, $\mathrm{n}^{\circ}$ 172, 2004, p. 115-126.

12. Breytenbach Breyten, A Veil of Footsteps: Memoir of a Nomadic Fictional Character, Cape Town and Pretoria, Human and Rousseau, 2008, p. 43. 
le monde $)^{13}$ and in this case, the world of social injustice. I suggest that additional ways of thinking may come from diverse ways of seeing what is happening in the continual reproduction of segregation and reintegration, something which flows through every hour of every day as people move from shops to streets to homes to spaces of communal engagement. The exceedingly interwoven patterns of movement which open and conceal connections indicate a need for "a critical perspective on ethnic and racial segregation [to which one could add gender, and class questions - AM] [which] requires us to acknowledge the gaps and silences in the data produced and the complexity, and often value-laden nature, of our interpretations ${ }^{14}$ ".

Such a critical perspective belies anything simplistic about addressing social justice in situations of "significant" ethnic, race, gender and class distinction. The history of state concentration on addressing spatial and other forms of urban injustice along contours of identifying crisis in the banlieue and focussing tremendous effort on all manner of "interventions" to attack unequal opportunity - to take one example, the ZEP (Zone d'éducation prioritaire) - has certainly identified the problem, but perhaps even massively failed to change it, at least as the political economy of the post 1973 period in many cities has exacerbated nascent inequalities and injustices. Urban and spatial justice do not come easily from the histories we see from the RER $\mathrm{B}^{15}$. It is easy to see that in the Paris region, at least after a few trips on RER B; perhaps more difficult to acknowledge in South Africa, in which at first sight, and second, and beyond, the realities of daily life persistently involve observation of distinction, discrimination, unfairness and probably injustice tied up with race and ethnicity. There the foregrounding of race and patterns of residence demarcated by race, so generally persistent as Christopher (in many works) observes meticulously, despite some areas of change, is surely the most common descriptor of urban space. Surely in such circumstances of the obviousness of racial oppression and injustice, and where space and race have been so welded, progress towards greater justice can be accomplished by breaking some of these links, by actions to shift older boundaries and to alter locations.

13. Lévy Jacques, Le Tournant geographique. Penser l'espace pour lire le monde, Paris, Belin, "Mappemonde", 1999.

14. Phillips Deborah, "Ethnic and Racial Segregation: A Critical Perspective", in Geogrpahy Compass, vol. 1, n 5, 2007, p. 1138-1159.

15. Dikeç Mustafa, "Police, politics, and the right to the city", op. cit.; Dikeç Mustafa, "Revolting Geographies: Urban Unrest in France", op. cit. 


\section{FORESHORE IN THE FOREGROUND}

Yet the stories of ethnic oppression and radical reform, which are so tightly plaited at La Muette in Drancy, are linked too in South Africa. The very same Beaudoin, architect of the Cité at La Muette, found himself in South Africa in the later years of the Second World War. Whilst La Muette served as deportation camp, radical change in the spaces of Cape Town were in the making, and those provided openings for professionals to expound theory and practice anew. In Cape Town Beaudoin's reforming vision and his skill at the new, even dramatic, space making project, came to bear on the creation of new spaces for a city which - it was hoped would rise to meet the challenges of the new post-war world. Retained by the city government of the day, Beaudoin sketched a hypermodern future for the new space of Cape Town - the foreshore, in the foreground of many aerial views of Cape Town's trademark beauties, literally reclaimed from the sea and offering a tabula rasa to such urbanists.

But Cape Town of course was a city almost three hundred years old and sticking the new foreshore onto the city was conceptualized and designed fully in relation to existing parts of the city. Along with - or better, in competition with - another modernist, Leslie Thornton White (who had arrived from London before the war), Professor of Architecture at the University of Cape Town, competing authorities jostling for control over the potentially rich returns from all this new land, appointed Beaudoin. Both produced grand plans for the reconstruction of central Cape Town, the differences between which revolved around different conceptions of the role of the railways and positioning of railway facilities, as well as the accrual of the spoils. Fierce dispute between the main actors was resolved by placing the competing plans in the hands of a Joint Technical Committee in 1945. That committee had little difficulty in adopting the City Council's plans for wholesale demolition in District Six, and new roads (the progenitors of the Eastern Boulevard which connects most of the population of Cape Town to the city centre, and more). By releasing District Six for commercial and industrial, as well as more salubrious residential uses, to the new foreshore - envisioned, according to Naomi Barnett ${ }^{16}$, as the recreation of inner Cape Town. What survived into the compromise plan was primarily the grand conception proposed by Beaudoin. It entailed pushing poorer tenants and other less financially endowed citizens out of the central districts. Through the sixties and seventies Cape Town was reshaped as the

16. Barnett Naomi, "Cape Town's District Six: destruction planned, 1940", unpublished paper, Dept of History, UCT, 1995. 
Cape Flats - the south east quarter of the city became the home to an overwhelming majority of its population, tied to the city centre on roads and railways realised over the same period. Much of what took place reflected the contradictions of modernist planning, as a certain zeal to create better design conditions for modern living - recognisable from twenties Moscow to thirties Paris to seventies Mitchell's Plain (SE Cape Town) - intertwined with particularly oppressive notions of ordering the city and the perpetual economic squeeze on accomplishing real improvement for the poor. In the dying days of apartheid, the last major elements of Cape Town's present space economy arrived with Khayelitsha, still further to the south-east and now home to something like a third of the citizens.

All this change in Cape Town had its roots in elements of space created 60 or more years ago, which have persisted and in the recent past been accentuated. Breyten Breytenbach writes of the city now in words not especially measured ${ }^{17}$.

The lines of economic and racial iniquity were still there for all to see, carved starkly in the living flesh of communities. Mile upon mile of "township"... informal settlements, shanty towns, squatter camps tumbled over the dunes and crawled from the scraggly undergrowth and teetered on the rubbish tips and overed the land... this satellite universe of tin and cardboard... Close to the business heart of the city, bordered by golf courses and verdant parks, were the affluent suburbs where the rich Whites - and increasingly also Blacks, Coloureds and Indians fleeing upcountry upheavals and insecurity - lived in houses set in gardens shaded by trees and surrounded by protecting walls... Around the sweep of mountain along edges of the sea you found apartment buildings of the affluent, those who jogged and strolled wearing baseball caps and outsize Greta Garbo hiding glasses as they walked their dogs...

One can hardly exaggerate how better life is for many in South Africa on many levels: at least in the largest cities, democracy has brought citizenship with degrees of respect for person and voice for millions - degrees of freedom indeed ${ }^{18}$. Yet the promise of "the rainbow nation of God" named by Desmond Tutu is more elusive than expected, and certainly the "rainbow city" has yet to replace the city of colonialism, segregation, apartheid, and indeed rapacious capitalism. An opening of public discourse over recent

17. Breytenbach Breyten, A Veil of Footsteps: Memoir of a Nomadic Fictional Character, op. cit.

18. For an informed yet testing celebration, see Pieterse Edgar, City Futures: Confronting the Crisis of Urban Development, London, Zed, 2008. 
months, a perverse effect of machinations in dominant party politics, has pulled back the rug to some extent, revealing or representing what the bumps underneath may be made of. Of course global anxiety so visible in parts of Europe and elsewhere, also permeates South African discourse (with its own tones of electricity shortages, violent crime and more), and much rhetoric is to be discounted. But sober editorials in every issue of, for example, the Sunday Times are nowadays addressing "where we are" with renewed inspiration. The terrible contest between the desire to claim progress and the need to excavate failure if injustice is to be confronted threads its way through such texts ${ }^{19}$.

And so, in Cape Town, with its tangled and ugly politics, where it is perhaps less possible than elsewhere to name spades openly, some yet muffled efforts to engage what it is which is frustrating realisation of the dream begin to emerge. Yet it is hard for locals to distance themselves from the anger surrounding Delft Symphony, and N2 Gateway ${ }^{20} \ldots$

Sometimes it is those from without who catalyse the process. In the city improvement districts established over the past five years on the edge and on the foreshore, abutting the hugely successful older harbour areas known as the Waterfront, is a realisation of something prefigured in the forties. How can this be in the land of the resounding defeat of apartheid 15 to 20 years ago? Dubresson offers a radical hypothesis derived from that which Heribert Adam, Van Zyl Slabbert and Kogila Moodley propounded a decade ago: that the new elite consciously or otherwise constructs new position through neo-liberalism, black empowerment and/or corruption - becoming an aristocracy of liberation ${ }^{21}$. Dubresson suggests that such instruments as city improvement districts could be portrayed as a vehicle for this process... with consequences that actions against the injustices of the society are muted. Here is something like a "urbanité selective" in the phrase of Thierry Paquot ${ }^{22}$.

19. See for example column by Mondli Makhanya in Sunday Times, 9 March 2008.

20. Cf. Mail and Guardian, 22 February 2008.

21. Dubresson Alain, "Urbanisme entrepreneurial, pouvoir et aménagement: les city improvement districts au Cap", in Le Cap après l'apartheid: Governance métropolitaine et changement urbain, Dubresson Alain and Jaglin Sylvy (eds), Paris, Karthala, 2008.

22. PAquot Thierry, Terre Urbaine: Cinq défis pour le devenir urbain de la planète, Paris, La Découverte, 2004. 


\section{FreEWAYS, SUBURBS, CITY REGIONS}

Such selectiveness is hardly unique to Cape Town. Further north, and back in South Africa in the 1950s, the apparently ebullient Beaudoin contributed another grand spatial conceptualisation. Sketching in charcoal on large sheets of paper (copies preserved in a collection at Wits University), Eugene Beaudoin helped to lay out the freeways which today remain the backbone of Johannesburg's central spatial structure and movement patterns. The most poignant feature of which is... the daily pilgrimage homewards from the northern employment areas to Soweto and other tracts of the southwest. For this is another city divided, less reunited than reproducing a series of exclusions and injustices on a vigorous scale, despite the dedicated intentions of a vigorous democratic local government. Assuming that Joburg's capacities in this regard are well known, from the burgeoning recent literature, let us pass on to some observations on this case $\mathrm{e}^{23}$.

The sense which inspired the colloquium emerges very strongly in Johannesburg as Claire Benit has indicated ${ }^{24}$. That is, spatial justice is not interrogated, seems obvious, is simply counterposed against spatial injustice. "La notion même de justice spatiale est restée peu questionnée tant elle s'est imposée comme une apparente évidence, souvent définie, d'ailleurs, à partir de la dénonciation des injustices spatiales ${ }^{25}$. The formation of single local ("metro") government for Joburg or Cape Town seems to have dealt with the problem of territorial fragmentation... but not to have dealt with continued processes generating new inequalities and new processes generating continued inequalities.

23. Holland Heidi and Roberts Adam, From Joburg to Jozi: Stories about Africa's Infamous City, Johannesburg, Penguin, 2002; Uniting a Divided City. Governance and social exclusion in Johannesburg, Beall Jo, Crankshaw Owen and Parnell Susan (eds), London and Sterling, Earthscan, 2002; Emerging Johannesburg: Perspectives on the Post-Apartheid City, Tomlinson Richard, Beauregard Robert, Bremner Lindsay and Mangcu Xolela (eds), New York, Routledge, 2003; Мвемве Achille and Nuttall Sarah, Public Culture, Special Issue: Writing the Global City from Johannesburg , 2004; BEAvon Keith, Johannesburg: the Making and Shaping of the City, Pretoria, University of South Africa Press, and Leiden, Koninklijke Brill, 2004.

24. Benit Claire, "La difficile définition de la justice spatiale à Johannesburg: un processus de démocratie participative", in Les Annales de la recherche urbaine, $\mathrm{n}^{\circ}$ 99, 2006, p. 48-59.

25. BARONE Sylvain, "La régionalisation de l'action publique contre l'égalité territoriale ?", École thématique internationale "Les recompositions territoriales et les transformations de l'action publique. Trois énigmes sur la construction des intérêts territorialisés", IEP de Grenoble, December 20-21 2007. 
Gentrification continues... even in central Joburg, with sales of new apartments in converted office buildings reaching prices unimaginable not long ago. "The rich are mobile, the poor are moved... an official drive to pretty up our cities by pushing out the poor. It's called 'urban renewal ${ }^{26}$." The suburbs seem archetypal, challenging even Ed Soja's description of suburbanism as reaching its peaks in Los Angeles ${ }^{27}$.

The highways sketched boldly in 1955 by Beaudoin provided one of the keys to the suburbanization of this city. Through the 1960s the creation of American-style suburban municipalities ensured that the trend accelerated, and the "completion" of a national freeway system through the seventies helped to cement the attractiveness of suburban investment location, with swooping highways achieving all manner of temporary goals (making money for the then party faithful, providing rapid military access like Eisenhower's "Interstate and Defence" highway system in the USA, and for a while moving the traffic along). Given the massive spatial inequalities of Johannesburg with its apartheid forms of segregation, which went together with huge disparities in public investment and maintenance spending across different areas, it was inevitable that the idea of "one city, one tax base" would form the elementary basis of an approach to local government for the post-apartheid $\mathrm{er}^{28}$. The optimism of the early nineties led many to believe in the transforming potential of this rearrangement as the suburban municipalities (Bedfordview, Edenvale, Sandton, Randburg, Midrand) were eliminated and mostly incorporated into Joburg or its neighbour, Ekurhuleni.

Yet investment continues to pour into the new and outlandish built environments of far-flung suburban Johannesburg perhaps best described by Ivan Vladislovic in his representations of the city ${ }^{29}$. Breytenbach, whose observations and expressions evoke so much elsewhere, unfortunately does not turn his pen to Joburg except to run from it.) Unified local govern-

26. Mail and Guardian, 22 February 2008, p. 8-9.

27. Mabin Alan, "Suburbs on the veld, modern and postmodern", draft paper accessible at http://web.wits.ac.za/NR/rdonlyres/3F8E77A8-AA92-4D28-BD1AC7FF240395CA/0/suburbs_on_the_veld_mabin.pdf, 2005; Czegledy André, "Getting Around Town: Transportation and the Built Environment in Post-Apartheid South Africa", in City \& Society, no 16/2, 2004, p. 63-92.

28. MABin Alan, "From hard top to soft serve: demarcation of metropolitan government in Johannesburg for the 1995 elections", in A Tale of Three Cities: the Democratisation of South African Local Government, Cameron Robert (ed), Pretoria, Van Schaik, 1999, p. 159-200.

29. Vladislovic Ivan, Portrait with Keys, Johannesburg, Umuzi, 2006. 
ment, so hard to achieve in the USA ${ }^{30}$ and many other places, came to Joburg: its prospect of addressing spatialities of injustice yet fail to be fulfilled despite tarring roads in Soweto and many other accomplishments of the local government which I in a small way helped to bring into being and which I have supported in many voluntary and voting ways.

It turns out that it is not easy to shift obvious spatial problems, something which may have been obvious but takes time to understand. Apartheid with its rather elaborate spatial apparatuses (for example the detailed apparatuses of implementation of the Group Areas $\mathrm{Act}^{31}$ ) constructed an obviously spatialised oppression. Surely, therefore, instruments of spatial planning could be applied to its undoing? Such was a frequent cry of the early years post apartheid. I remember well an official coming out of the old regime and enthusiastically embracing the new in 1996, saying in a meeting in Gauteng's Department of Development Planning on how to craft new land use management: "We used land planning to install apartheid, we can just use similar instruments to undo it" and she was far from alone in this view. What does this ignore? Presumably the flowing together of the broader social system and state action towards greater polarization and greater injustice? This would certainly be the position of Abahlali in Durban $^{32}$ - but its demand to remove capitalism in order to achieve social justice, something which it shares with the Anti-Privatisation Forum in Johannesbug, seems unlikely to be achieved in the near future, despite the gestures of Purcell ${ }^{33}$ and many others in the literatures. What else can be done? Slogans demanding "Build no social segregation" point in interesting directions but as recent "integrated human settlements" seem to show like Cosmo City in the suburbs of Johannesburg - not easy to sustain.

Finally on Joburg: its setting is not isolated. For manageability reasons perhaps one tries to confine an account of its history to something like its present boundaries ${ }^{34}$. But for many tens of kilometers beyond, it is of course surrounded by South Africa's major zone of urbanism - Gauteng.

30. But see Economist, 8 March 2008.

31. Mabin Alan, "Comprehensive segregation: the origins of the Group Areas Act and its planning apparatuses, c. 1935-1955", in Journal of Southern African Studies, vol. 18, $\mathrm{n}^{\circ}$ 2, 1992, p. 406-429.

32. Abahlali, http://abahlali.org/node/2875, 2007.

33. Purcell Mark, "Citizenship and the right to the global city: reimagining the capitalist world order", in International Journal of Urban and Regional Research, vol. 27, n 3, 2003, p. 564-590.

34. E. g. Beavon Keith, Johannesburg: the Making and Shaping of the City, op. cit. 
Since the State of the Cities report a few years ago emerged from the government-linked SA Cities Network, it has again been fashionable to talk of this as a single city region - an idea which comes to us from around 1950 if not before, but which remains contested. Certainly as Dikeç ${ }^{35}$ has it: "what is at issue is the larger city region" and not simply parts of it however much attention they draw. Social and spatial justice in Gauteng - is this the scale at which we need to think? Does it help, in revealing any processes or dynamics which operate in ways to pervert and defeat well meaning attempts to redress injustice and inequality? I think the answer is yes, but I do not think that elaborating that answer will come from compiling more statistics and tracking more closely a huge range of indicators compiled at regional or even detailed subregional scale, however important the data may be for drawing the picture descriptively. It is in better understanding of how people travelling from Hammanskraal in the northern reaches of Tshwane to work in Alberton, and trying to cope with extended families spread from Naledi to Tsakane, linked to places like Nebo and Nqutu... in how people understand and experience the cleavages and unities of this vast "global city region" that some prospects seem to exist for identifying the things which are susceptible to immediate more equal, more just, social action. What is clear is that amongst other lacks is a conceptualization of the city region in these senses, something to be worked on in times to come.

\section{HOW TO GRASP, TO EXPLAIN, TO OFFER WAYS OF MOVING ON?}

Now, my tales are told, and the questions of the colloquium remain. What difference does justice make to space, what difference does space make to justice? Are such differences consistent across scales, or haphazard, or does scale itself make a difference? If the challenge is to do something under exceedingly difficult circumstances, apparently - we could merely conclude that it seems that the chances of a socially just city are negligible ${ }^{36}$. How to move beyond such depressing conclusions, if at all?

Most of the conceptions offered towards why we are not hitting social and spatial injustice head on are at large scale. Shall we blame globalization? To

35. Dikeç Mustafa, "Justice and the spatial imagination", in Environment and Planning A, vol. 33, n 10, 2001, p. 1785-1805.

36. Morris Alan, "Decade of Post-Apartheid: Is the City in South Africa Being Remade?", in Safundi: The Journal of South African and American Studies, ${ }^{\circ}$ 13-14, April 2004. 
some extent that is what I do in earlier work ${ }^{37}$. But what else is going on? We can take the line that the "strong affiliation of the post-apartheid government to a neo-liberal economic policy, low economic growth, pervasive poverty, high levels of unemployment, and the crisis engendered by the HIV/AIDS epidemic ${ }^{38 "}$ are responsible, and perhaps they are.

Another approach might be to see what has made possible some of the more interesting new developments where people have "got on with it" and pulled down resources - to create quite new forms of space and insertion into the city - in ways which seem to sustain themselves - and which perhaps are indicating possibilities of greater "spatial justice". The example of the Johannesburg Housing Company and its Brickfields development in Newtown comes to mind. This is a creatively designed space of hundreds of new apartments which create opportunity for "ordinary people"-employed but not well paid, with regular incomes but not with real savings, to reside in the very centre of Johannesburg again. It is a complex which is partly supported by public funds and which demands regular rental payment from its residents. It is most certainly in a place which opens possibilities of participation in urban life and which offers much less expensive movement around the city by virtue of its location, than can possibly be the case for the large majority stuck out towards the periphery in Orange Farm and Diepsloot, or for that matter stuck in traffic congestion on the freeway system. It bears much more investigation, which has to address its contributions to individual lives as well as the iron rod needed to prevent problems such as those that have crept in to some other cases (like coop versions in Burghersdorp nearby); and the possibility that its expense cannot be replicated really widely.

Such examples tend to reinforce a sense of contingency which can be tackled rather than grand theory which can only most distantly be applied. This is why Rasmussen criticizes Soja for "sweeping theoretical gestures, accompanied by a litany of academic description that leave us in a city that appears to be a figment of the L.A. school's intellectual imagination ${ }^{39}$ ". She prefers Abu-Lughod's account of "an urban politics - deeply embedded in

37. Mabin Alan, "Suburbanisation, segregation and government of territorial transformations," in Transformation, $\mathrm{n}^{\circ}$ 57, 2005, p. 41-63.

38. Morris Alan, "Decade of Post-Apartheid: Is the City in South Africa Being Remade?", op. cit.

39. Rasmussen Claire, "Reading the L.A. landscape", http://www.electronicbookreview.com/thread/internetnation/metropolitan, 2001. 
globalized processes - that struggles with the inability of empirical and historical narrative to capture the 'essence' of the city".

Without wishing to comment on the validity of this specific observation, all too often policy portrayal of Gauteng appears to me to remain in the realm of "sweeping gesture". Authors originating from less spatially charged disciplines than geography and urban planning often have things to say which help to break the ice. For example, Rengert notes: "Spatial variation in crime rates generally has been attributed to differences in culture, economic status, and the social organization of communities. Rarely have policies and practices of criminal justice professionals been examined as causes of this variation ${ }^{40}$ ". The spotlight moves towards the practices of professionals if we can build on such observations.

After all, what is it which we are trying to figure? Something which the simple phrase "spatial justice" may even tend to conceal ${ }^{41}$, since it is the complexity of the dialectic as Dikeç insists across his work, which needs complex action. For me that implies complex concept of practice and indeed complex professional practice. But is such achievable? "How then, can we better exercise [the] right to the city? But whose rights and whose city? Could we not construct a socially just city? But what is social justice? Is justice simply whatever the ruling class wants it to be ${ }^{42}$ ?". It appears to me that "an active right to make the city different, to shape it more in accord with our heart's desire, and to re-make ourselves thereby in a different image ${ }^{43}$ " is an attractive, even exciting prospect: but the pragmatist gets the better of me, and I want to see what urban planning can do to contribute, now.

\section{Planning and SPATiality of JUstice, Injustices of SPATIAlity}

Since planners plan, they claim that their local, regional or national spatial plans are crucial for achieving spatial equity ${ }^{44}$. Certainly creating "mental visions" at whatever scales is part of the work of planning. I would go so

40. Rengert George F., "Spatial justice and criminal victimization", in Justice Quarterly, vol. 6, n 4, 1989, p. 543-564.

41. Pirie Gordon H., "On spatial justice", in Environment and Planning A, vol. 15, $\mathrm{n}^{\circ} 4$, 1983., p. 465-473.

42. Harvey David, "The right to the city", in International Journal of Urban and Regional Research, vol. 27, n 4, 2003, p. 939-941.

43. Ibid.

44. Kunzmann Klaus R., "Planning for spatial equity in Europe”, in International Planning Studies, vol. 3, n 1, 1998, p. 101-120. 
far as to say that urban planning has at times constituted one of the key means of attempting the pursuit of spatial justice. The idea that achievement of social goals depends on achieving greater spatial justice has held such sway in several contexts that some have even argued that urban planning and the search for spatial justice are equivalent. But others argue that they are almost mutually exclusive, since the results of urban planning are frequently quite different from explicit goals and intentions. As Erminia Maricato put it in Joburg in 2006: "There is a very huge gap between rhetoric and action ${ }^{45}$.

In South Africa it is claimed that the legacy of apartheid makes the search for spatial justice the focus of any planning activity ${ }^{46}$. We have seen how presently powerful patterns of suburbanisation of business activity and middle class residence, and location of new housing projects aimed at poorer citizens in peripheral urban situations has tended to deepen rather than alleviate the legacy of apartheid and there is a widespread search for ways of (1) achieving progress towards spatial justice and (2) reducing the negative environmental impacts associated with the sprawling forms of urban development in evidence. What is it that stands between planning and achievement? And this is not a South African but a global quest, surely. Cardoso and Breda-Vázquez argue that the tensions of modernism in Portuguese planning undermine the theoretical capacity of practices to achieve socially just territories ${ }^{47}$. Valuable as this analysis is, for me the question is not merely one of conceptions of method and process in planning which have such distinctly modernist roots, but the "real" practices of professionals in contemporary situations which require interrogation. To try to go beyond the images of planning so effectively painted by Susan Fainstein, it is not merely the roles of planners as mediators, the physical pictures of a desirable planned city they paint, or even the attempt to inject equity into planning ${ }^{48}$. It is not only that normative theories of planning face chal-

45. Maricato Erminia, "On progressive urban policy", paper presented to CUBES symposium, University of the Witwatersrand, January $28^{\text {th }}, 2006$.

46. Harrison Philip, Todes Alison and Watson Vanessa, Planning and Transformation, London, Routledge/RTPI, 2008.

47. Cardoso Ricardo and Breda-VÁzquez Isabel, "International Social Justice as a Guide to Planning Theory and Practice: Analyzing the Portuguese Planning System", in International Journal of Urban and Regional Research, vol. 31, $\mathrm{n}^{\circ}$ 2, 2007, p. 384-400.

48. Fainstein Susan, "New Directions in Planning Theory", in Urban Affairs Review, vol. $35 \mathrm{n}^{\circ}$ 4, 2000, p. 451-478. 
lenges in African urban context ${ }^{49}$ - or for that matter in Île-de-France's vast complexity and diversity. It is not only the central assumptions of normative theory which seem inadequate.

Pieterse claims that "there is an urgent need to reinvigorate civil society in these cities, to encourage radical democracy, economic resilience, social resistance and environmental sustainability folded into the everyday concerns of marginalised people $e^{50}$ ". That path is actually one of optimism about (state based) planning and its potential for social and spatial justiceas long as planners can listen ${ }^{51}$. A much more disturbing idea comes from thinking that there are systemic defeats of intention and an intrinsic corruption of intent on the path to accomplishment. It is unfortunately the antithesis of the optimistic view, which could be illustrated like this: "All it needs is visionary planning authorities guided by utopian images of a clean, safe and just city, and well-designed, appropriate policies to direct Cairo's steps into this direction. All it needs, moreover, is citizens who actively take part in the molding of the city's shape $\mathrm{e}^{52} \ldots$..”. This optimistic view is exactly what we had thought in Johannesburg and Cape Town, exactly what some propound in Paris. Yet when the conditions are achieved, the realization eludes. Criticism is stifled: politically linked officials may ice continued participation in discussion of reasonably informed but undisciplined commentators, researchers, consultants and others, some of whom are effectively constructively dismissed from employment and others simply lose access - I am contemplating how to write about my own experience and observation of these things, not easy to do.

Presently my thinking is provoked by the simple observations from Roissy Express on the massive amounts of time and professional energy invested in urban policy planning and discussion. "It's crazy how many meetings there have been in recent years to reflect on the problems of the suburbs $s^{53}$. The effort seems to fail on the "Everyday poverty that's rising, rising, and just goes on rising without bothering whether it's in Paris or outside". It seems

49. Watson Vanessa, "The Usefulness of Normative Planning Theories in the Context of Sub-Saharan Africa”, in Planning Theory, vol. 1, n 1, 2002, p. 27-52.

50. Pieterse Edgar, City Futures: Confronting the Crisis of Urban Development, op. cit.

51. Roy Ananya, "The location of practice", in Development Southern Africa, vol. 24, n 4, 2007, p. 623-628.

52. Al-BaAly Mohammed, The future Amsterdam of the Middle East?, World Bank Essay Competition, Building a Secure Future - Seeking Practical Solutions, http://www.essaycompetition.org/docs/essays2005/al\%20baaly.pdf, Cairo, 2005.

53. Maspero François, Roissy Express, op. cit. 
that despite frequent citation of Lefebvre, "consciousness of the city and of urban reality is dulled ${ }^{54 "}$ as the meetings grind on.

The contrast between self-initiated organizations and their apparent relative lack of corruption - burial societies being a classic, superb example - with the intrinsic corruption of state based work is a cause for pondering $^{55}$. Perhaps the emphasis, in South Africa, could fall more on "how to develop the local state rather than how it can be developmental ${ }^{56 "}$. I am suggesting that if planning is to contribute towards spatial justice, we have to address the inadequacy of any form of local state machinery to create a neutral political environment while development projects (driven by national and international funds, with lots of billboards and speeches at meetings claiming credit for the same) are implemented - governance in other words is ineffectual at precisely this conjuncture. Just possibly this is rooted in a form of governance which requires "more concern and respect" for the office of the president than for the "office of the citizen ${ }^{57}$ ". Huchzermeyer, Bahre, Mde, Khanyane and Staniland ${ }^{58}$ offer to my reading (whatever the authors intended) more detailed analyses of how the hierarchical context, deference to power, prioritisation of party position, associated clientelism and nepotism, as well as a failure to challenge the consequences of top line personnel and personal advancement policies and politics, are combining

54. Lefèbvre Henri, Writings on Cities, E. Kofman and E. Lebas (trans.), Oxford, Blackwell, 1996.

55. Niehaus Isak comment on BäHRE Erik, "How to ignore corruption: reporting the shortcomings of development in South Africa. Commentary and Author's reply", in Current Anthropology, vol. 46, n 1, 2005, pp.107-120, p. 115.

56. Sivaramakrishnan K. and Agrawal Arun, "Regional Modernities in Stories and Practices of Development", in Regional Modernities: Cultural Politics of Development in India, Sivaramakrishnan K. and Agrawal Arun (eds.), Stanford, Stanford University Press and Delhi, Oxford University Press, 2003, p. 1-63.

57. Aubrey Matshiqi, in Business Day, August 17th 2005.

58. Huchzermeyer Marie, "Challenges facing people-driven development in the context of a strong, delivery-oriented state: Joe Slovo Village, Port Elizabeth", in Urban Forum, $\mathrm{n}^{\circ} 17$ (1), 2006, p. 25-53; BäHRE Erik, "How to ignore corruption: reporting the shortcomings of development in South Africa. Commentary and Author's reply", op. cit.; V. Mde, in Business Day, July 5 ${ }^{\text {th }}$, 2005; Kanyane Modimowabarwa, Conflict of interest In South Africa: a comparative case study, unpublished Doctor of Administration thesis, Faculty of Economic and Management Sciences, School of Public Management and Administration, University of Pretoria, 2005; STANILAND Luke, “They know me, I will not get any job': public participation, patronage and the sedation of civil society in a Capetonian township", Paper presented to conference Place of participation in a democratizing country, HSRC-IFASCUBES, Wits University, November 2006. 
to create elements of an understanding of the environment in which planning, plan, environment and action interact in ways which defeat the ends of spatial justice. Whilst political competitors focus on allegations (and in some cases evidence) of straightforward corruption ${ }^{59}$, the social anthropology of power and relationships within and around local government seem more significant in generally frustrating achievement of greater justice.

Is this simply a normal environment? Do Maspero's notes of incredulity on how he became an expert after Roissy Express - yet another input into a vast machine of urban policy and planning reproducing, ignoring or missing spatial injustice - indicate that South African city planning is catching up fast? And how to grapple with this type of system without grand gesture, in the quest for something different, if not merely romantic? At the risk of encouraging more talk, but in common with other authors ${ }^{60}$, I propose that more scholarly engagement with questions of why planning (and its professional relatives) struggles to grapple with spatial injustice, would be greatly encouraged by events succeeding the provocative symposium at which these thoughts were first presented.

Alan Mabin

School of Architecture and Planning, University of the Witwatersrand, Johannesburg

59. E. g. Democratic Alliance, "The Rot in ANC municipalities: Five case studies of cronyism, corruption and ineptitude", www.da.org.za/da/Site/Eng/campaigns/ DOCS/SA_Awards4.doc, 2005.

60. Marcuse Peter, Connolly James, Novy Johannes, Olivo Ingrid, Potter Cuz, STEIL Justin, Searching for the Just City: Debates in Urban Theory and Practice, London, Routledge, 2009. 



\section{ségrégation et justice spatiale}

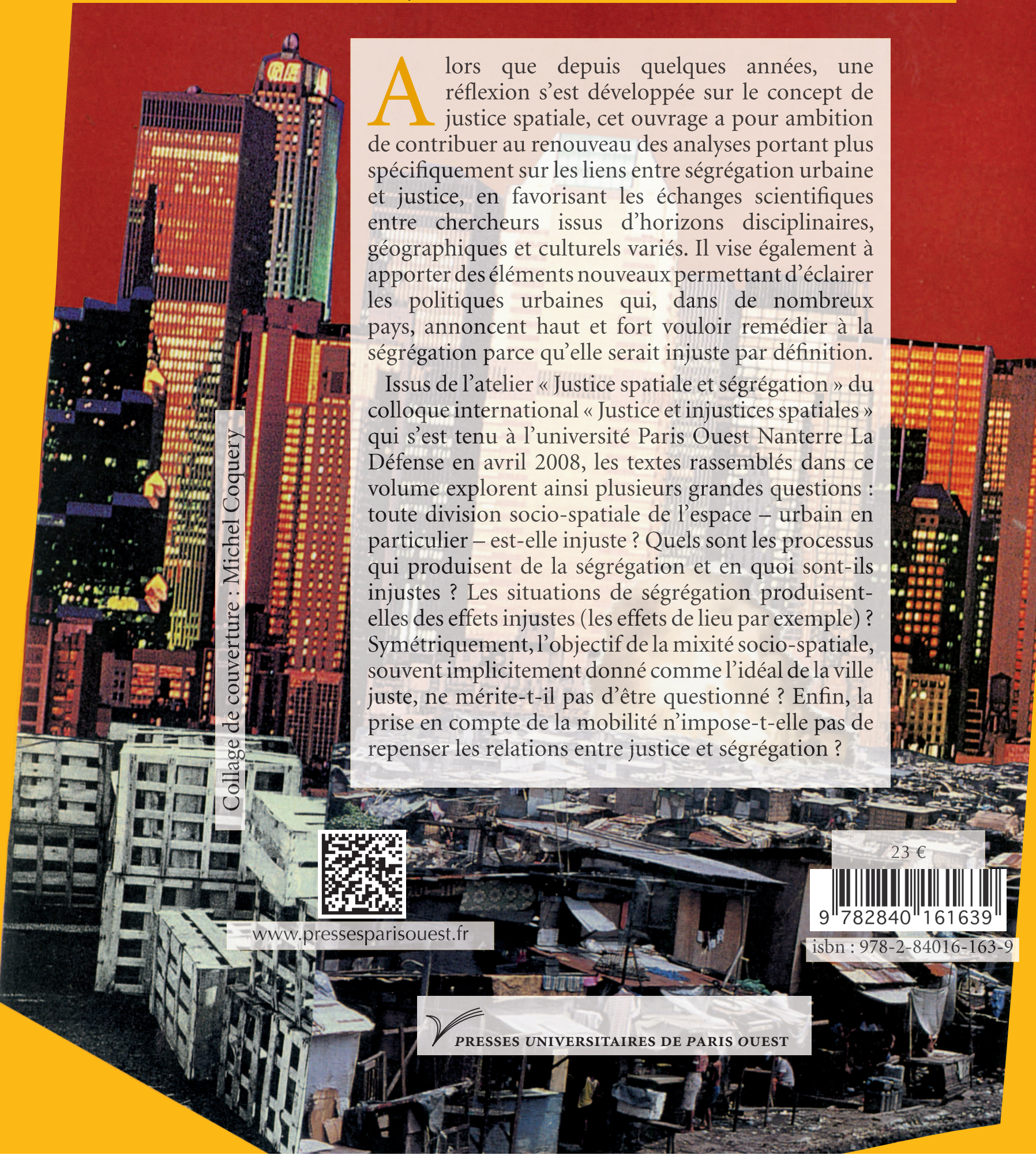

